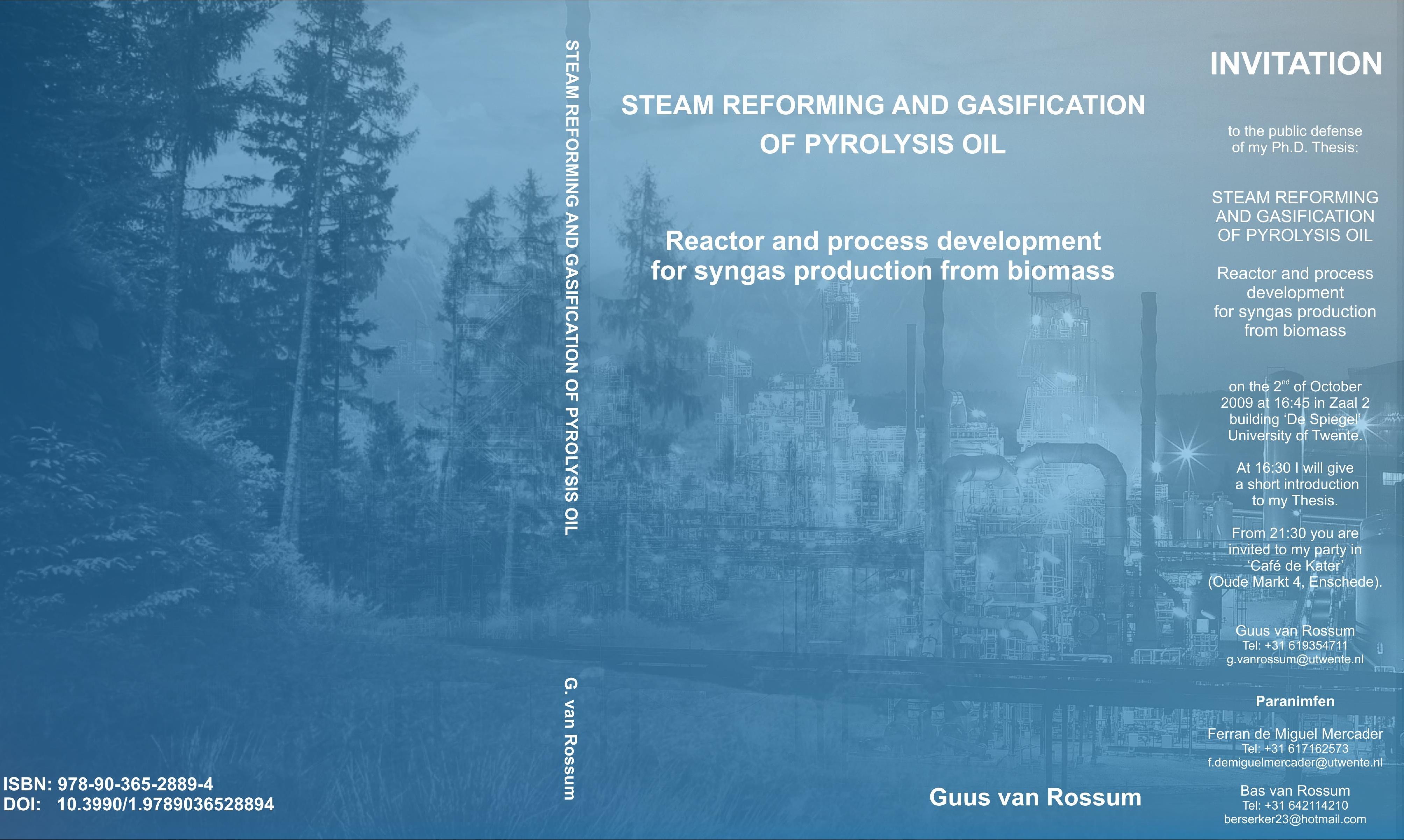


Steam reforming and gasification of pyrolysis oil

Reactor and process development

for syngas production from biomass 


\title{
Members of the committee
}

Chairman/Secretary:

Promotor:

Assistant promoter:

Members: prof. dr. G. van der Steenhoven prof. dr. ir. W.P.M. van Swaaij dr. S.R.A. Kersten

dr. ir. D.W.F. Brilman

dr. S. Czernik

prof. dr. ir. M.J. Groeneveld

prof. dr. ir. H.J. Heeres

prof. dr. ir. J.A.M. Kuipers

prof. dr. ir. L. Lefferts

prof. dr. ir. W. Prins
University of Twente

University of Twente

University of Twente

University of Twente NREL (USA)

University of Twente

University of Groningen

University of Twente

University of Twente

Ghent University, BTG

The research described in this Thesis was financially supported by the Sustainable Hydrogen Program (053.61.007) of Advanced Chemical Technologies for Sustainability (NWO).

Part of the research was co-financed by the European Union (Bioelectricity, ENK5 CT-2002-00634).

\section{Steam reforming and gasification of pyrolysis oil}

Reactor and process development for syngas production from biomass

\author{
By Guus van Rossum
}

Ph.D. Thesis, University of Twente

Printed by Ipskamp Drukkers B.V., Enschede, The Netherlands.

(C) G. van Rossum, Enschede, The Netherlands, 2009.

No part of this work may be reproduced by print, photocopy or any other means without the permission in writing from the author.

ISBN: 978-90-365-2889-4

DOI: $\quad 10.3990 / 1.9789036528894$ 


\title{
STEAM REFORMING AND GASIFICATION OF PYROLYSIS OIL
}

\author{
REACTOR AND PROCESS DEVELOPMENT \\ FOR SYNGAS PRODUCTION FROM BIOMASS
}

PROEFSCHRIFT

ter verkrijging van de graad van doctor aan de Universiteit Twente, op gezag van de rector magnificus, prof. dr. H. Brinksma, volgens besluit van het College voor Promoties

in het openbaar te verdedigen

op vrijdag 2 oktober 2009 om 16.45 uur

door

\section{Guus van Rossum}

geboren op 8 februari 1979

te Leiden 
Dit Proefschrift is goedgekeurd door:

Promotor: $\quad$ prof. dr. ir. W.P.M. van Swaaij

Assistent promotor: dr. S.R.A. Kersten

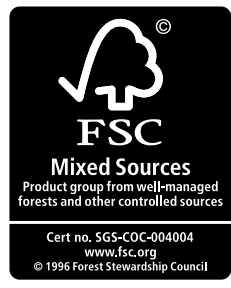

iv 


\section{Contents}

$\begin{array}{ll}\text { Samenvatting } & 1\end{array}$

$\begin{array}{ll}\text { Summary } & 7\end{array}$

$\begin{array}{lll}\text { Chapter } 1 & \text { Introduction } & 11\end{array}$

Chapter 2 Catalytic and Noncatalytic Gasification of 43

Chapter 3 Staged Catalytic Gasification/Steam Reforming of Pyrolysis Oil

Chapter 4

Evaporation of Pyrolysis Oil: Product

Distribution and Residue Char Analysis

Chapter 5 Design of Efficient Catalysts for Gasification of Pyrolysis Oil Char

Appendix I

Steam Reforming of Vapors/Gases Released during Commercial Charcoal Production

Appendix II

System Configurations for the Conversion of Pyrolysis Oil to Fuel Cell Electricity

Dankwoord

Curriculum Vitae

Publications 


\section{Samenvatting}

De Mensheid heeft duurzame energie nodig om zijn impact op de aarde zo aan te passen dat een groeiende en economisch zich ontwikkelende populatie gehuisvest kan blijven. Biomassa is een speciale duurzame bron omdat het, behalve voor warmte en stroom, ook gebruikt kan worden voor de productie van chemicaliën en vloeibare transportbrandstoffen. Voor deze laatste toepassing wordt pyrolyse van biomassa voorgesteld als een tussenliggende stap om van de relatief droge (afval)stroom van biomassa 'herwinbare ruwe olie' (pyrolyse-olie genoemd) voor raffinage te maken. In deze stap moet de technologie om fossiele brandstoffen te maken aangepast worden omdat biomassa voedingen een wezenlijk andere chemische samenstelling hebben dan hun fossiele tegenhanger.

Het onderzoek dat in dit Proefschrift is beschreven betreft het stoom reformen en vergassen van pyrolyse-olie om synthesegas en/of waterstof te maken. Wanneer synthesegas en/of waterstof eenmaal zijn gemaakt, kan de biomassa-productielijn gekoppeld worden aan de bestaande productielijnen in de petrochemische industrie die op fossiele aanvoerstoffen is gebaseerd en kan biomassa een bron worden voor waterstofproductie voor een snel groeiende markt.

Allereerst is een opstelling ontworpen, gebouwd en operationeel gemaakt om het stoomreformproces te bestuderen en te ontwikkelen. De grote uitdaging in deze opstelling was om hoge temperaturen, nodig voor het stoom reformen $\left(\sim 800^{\circ} \mathrm{C}\right)$, te combineren met de relatief lage temperaturen, die nodig zijn voor het versproeien van koude pyrolyse-olie $\left(\sim 40{ }^{\circ} \mathrm{C}\right)$. Pyrolyse-olie is instabiel bij hoge temperaturen en produceert kool waardoor voedingsleidingen makkelijk kunnen verstoppen. Een speciaal voor deze opstelling ontworpen, watergekoelde versproeier kon direct geplaatst worden in een heet 
reactor(wervel)bed. Aanvankelijk werd alleen een zandwervelbed gebruikt om pyrolyseolie te vergassen. Hiermee werden niet-katalytische data verkregen die gebruikt konden worden als referentiepunt voor het katalytisch reformen. Er werd aangetoond dat bij temperaturen $\geq 700{ }^{\circ} \mathrm{C}$ en verblijftijden van $\sim 10$ s de pyrolyse-olie volledig werd vergast, waarbij slechts kleine hoeveelheden dampen overbleven (teren). Het niet-katalytische geproduceerde gas kan als zodanig alleen gebruikt kan worden als stookgas (bv. voor in een cementoven), maar heeft verdere opwerking nodig voor gebruik als synthese- of waterstofgas. De toepassing van speciaal ontworpen en commercieel verkrijgbare katalysatoren in wervelbedden liet eerst een hoge katalytische activiteit zien, waarbij synthesegas werd geproduceerd voor $\sim 15 \mathrm{~min}$. Er werd echter al snel verlies van katalytische activiteit waargenomen hetgeen resulteerde in een toenemende hoeveelheid methaan en $\mathrm{C}_{2}^{+}$. Dit katalytische activiteitsverlies werd voornamelijk toegeschreven aan sinteren en attritie. Zo werd duidelijk welk grote uitdaging voor katalysatorontwikkelaars ontstaat wanneer een één-reactor-concept is beoogd, namelijk het ontwikkelen van een katalysator, die zowel zeer actief als mechanisch sterk is.

Naast problemen met de stabiliteit van de katalysator heeft een één-reactor-concept nog meer nadelen omdat in één reactorvat twee in essentie verschillende processen (verdampen en katalytische conversie) uitgevoerd worden die beide veel warmte vragen. Vanwege bovengenoemde nadelen werd een getrapt proces voorgesteld dat bestaat uit verdamping/vergassing van olie in een apart 'inert' zandwervelbed als eerste stap, en stoom reformen in een vast katalytisch bed als tweede stap. Gebruik makend van een commercieel verkrijgbare katalysator werd op een uniforme, hoge temperatuur $\left(\sim 800{ }^{\circ} \mathrm{C}\right)$ een synthesegas geproduceerd zonder activiteitverlies van de katalysator gedurende $\sim 11 \mathrm{~h}$.

Het getrapte stoomreformreactor-concept werd vervolgens uitvoerig bestudeerd. Aangetoond werd dat de temperatuur van de verdampingssectie aanzienlijk verlaagd kon worden $\left(\sim 500{ }^{\circ} \mathrm{C}\right)$ hetgeen behalve een makkelijkere proces-integratie nog een groot voordeel heeft: op deze wijze kunnen geoxygeneerde dampen, die reactiever zijn dan een thermisch gekraakt gas (stookgas), direct in contact worden gebracht met het katalytisch bed. Verschillende groepen verrichten uitvoerig onderzoek om speciale katalysatoren te ontwikkelen voor deze componenten. Ook aan de Universiteit Twente wordt parallel onderzoek verricht (Berta Matas Güell, verdediging op 9 oktober 2009). De temperatuur 
van het katalysatorbed kon niet verder verlaagd worden dan tot $700{ }^{\circ} \mathrm{C}$, omdat de geoxygeneerde dampen bij lagere temperaturen verkolen op de katalysator.

Het getrapte reactorconcept was ook thermodynamisch gemodelleerd zodat onderzocht kon worden welke invloed commerciële operationele condities hebben op het geproduceerde gas en welke opties er zijn voor warmtetoevoer aan de verdampingssectie en aan de endothermische reformer. Er werd aangetoond dat vanuit efficiëntieoogpunt, externe brandstofverbranding geprefereerd wordt boven interne verbranding van kool of gerecirculeerd productgas. Externe brandstofverbranding wordt ook geprefereerd vanuit het oogpunt van bedrijfsvoering. Bij hoge bedrijfsdrukken ( $\sim 30$ bar $)$, die wenselijk zijn voor synthesegasapplicaties, laten de resultaten zien dat de katalytische uitgangstemperatuur hoog moet zijn $\left(\sim 900-1000 \quad{ }^{\circ} \mathrm{C}\right)$ om methaanvorming te minimaliseren. Als waterstof niet het gewenste product is maar synthesegas, dan moet de $\mathrm{H}_{2} / \mathrm{CO}$ verhouding af te stemmen zijn voor de synthese van methanol, DME en FischerTropsch ( 2-3). Dit zou gedaan kunnen worden door toevoeging/terugvoering van $\mathrm{CO}_{2}$ aan het systeem zodat zowel stoom reformen als droog reformen plaatsvindt.

Ten slotte is een belangrijk deel van het proces in detail bestudeerd, namelijk de koolproductie tijdens verdamping en de mogelijkheden om de gevormde kool om te zetten. Tijdens de verdamping wordt pyrolyse-olie omgezet in drie hoofdproducten: gas, damp en kool. Het gas en de damp kunnen omgezet worden over een stoom-reformkatalysator, maar de kool is mogelijk nadelig voor de uitvoering van het proces en verlaagt de algehele efficiëntie. Koolvorming moet dus geminimaliseerd worden of de gevormde kool moet omgezet worden via verbranding (om warmte voor het proces te genereren) of via stoom- en/of $\mathrm{CO}_{2}$-vergassing. De hoeveelheid kool die gevormd wordt is afhankelijk van de toegepaste opwarmingssnelheid tijdens het verdampen: hoe hoger de opwarmingssnelheid hoe minder kool er gevormd wordt. Een hoge opwarmsnelheid kan gerealiseerd worden door heel kleine pyrolyse-olie druppels te creëren via versproeiing. De zo gevormde kool is erg licht/vlokkerig en moet goed in contact gebracht worden met een drager en daarop verankerd worden zodat meevoering uit de reactor wordt voorkomen. De reactiviteit van de gevormde kool is vergelijkbaar met die 
van biomassa-pyrolyse-kool. Dat is hoog genoeg voor verbranding, maar niet hoog genoeg wanneer interne stoomvergassing wordt beoogd.

Een katalytisch actief materiaal (Ce-Zr-O) is ontwikkeld waarop de kool onder gecontroleerde condities gelijkmatig gedeponeerd kon worden. Daarbij werden moleculaire bindingen gevormd tussen de kool en de katalysator. De Ce-Zr-O katalysator levert zuurstof, zodat de koolvergassing versneld wordt. Deze katalysator kan geregenereerd worden door zowel stoom als $\mathrm{CO}_{2}$. De verkregen stoom- en $\mathrm{CO}_{2}$-vergassingssnelheden zijn een orde hoger dan niet-katalytische vergassing. 


\section{Summary}

Mankind needs sustainable energy to adjust its footprint so the earth can support a growing and economically developing population. Biomass is a special sustainable energy source since, besides heat and power, it can also be used for the production of chemicals and liquid transportation fuels. To convert relatively dry biomass (waste) streams, pyrolysis of biomass is proposed as an intermediate step to create a 'renewable crude oil' (called pyrolysis oil) for refining. To do this, technology for making fossil fuels has to be adapted to biomass feedstocks since its chemical composition is essentially different from its fossil counterparts.

The research described in this Thesis deals with steam reforming and gasification of pyrolysis oil to produce syngas/hydrogen. By producing syngas and/or hydrogen, biomass can be linked to the existing fossil based petrochemical industry and can serve as a source of hydrogen for a rapidly growing market.

In order to study the steam reforming process, initially a process development unit was designed, built and debottlenecked. Major challenges in the setup were to combine temperatures needed for steam reforming $\left(\sim 800^{\circ} \mathrm{C}\right)$ with cold pyrolysis oil $\left(\sim 40{ }^{\circ} \mathrm{C}\right)$ atomization. The pyrolysis oil becomes unstable and produces char at high temperatures which can easily block feed lines. A, for that purpose specially designed, water cooled atomizer could be placed directly into the hot (fluidized) reactor bed. Initially, only a sand fluidized bed was used to gasify pyrolysis oil. In this way, noncatalytic data were obtained as a benchmark for catalytic reforming. It was shown that at temperatures $\geq 700{ }^{\circ} \mathrm{C}$ and vapor residence times of $\sim 10 \mathrm{~s}$ the pyrolysis oil was fully gasified with only minor amounts of vapors remaining (tars). The gas produced noncatalytically is a typical fuel gas which needs further upgrading or as such can only be used as a dirty combustion 
gas (e.g. for in cement kilns). The application of dedicated designed and commercially available catalysts in the fluidized bed showed initially a high catalytic activity (producing syngas for $\sim 15 \mathrm{~min}$ ) but soon catalyst activity loss was observed which resulted in increasing methane and $\mathrm{C}_{2}^{+}$productions. This catalyst activity loss was mainly ascribed to sintering and attrition which uncovered a major catalyst development challenge for when a single reactor concept is envisaged: to develop a highly active and mechanically strong catalyst.

Besides catalytic stability problems, a single reactor concept had more disadvantages since two essentially different but high heat demanding processes (evaporation and catalytic conversion) are done in a single vessel. A staged reactor concept was proposed consisting of a separate 'inert' sand fluidized bed for oil evaporation/gasification and a fixed catalytic bed for the steam reforming. Using a single high temperature $\left(\sim 800{ }^{\circ} \mathrm{C}\right)$ and a commercially available catalyst, syngas was produced without activity loss of the catalyst for $\sim 11 \mathrm{~h}$.

The staged steam reforming reactor concept was extensively studied. It was shown that the temperature of the evaporator section could be lowered significantly $\left(\sim 500{ }^{\circ} \mathrm{C}\right)$ which besides more easy process integration had a very big advantage: in this way oxygenated vapors could be contacted directly with the catalytic bed instead of a thermally cracked gas (fuel gas). These oxygenates are more reactive and extensive research has been done to develop dedicated catalysts for these compounds by various groups and also in a parallel investigation at Twente University (Berta Matas Güell, Thesis defense $9^{\text {th }}$ of October 2009). The catalytic bed temperature could not be lowered too much $\left(\geq 700{ }^{\circ} \mathrm{C}\right)$ due to coking of the oxygenated vapors on the catalyst at low temperatures.

The staged reactor concept was also modeled thermodynamically to see how commercial operation conditions would have an impact on the produced gas and what the options are for supplying heat to the evaporation section and to the endothermic reformer. It was shown that from an efficiency point of view, external combustion of a fuel is preferred over internal combustion of carbon or recirculated product gas. External fuel combustion is also preferred from a process operation point of view. At high operating pressures ( $\sim 30$ bar), which are desired for syngas applications, results show that the 
catalytic exit temperature should be high $\left(\sim 900-1000{ }^{\circ} \mathrm{C}\right)$ to minimize methane production. If hydrogen is not the desired product but syngas, the $\mathrm{H}_{2} / \mathrm{CO}$ ratio should be tunable for applications like methanol, DME and Fischer-Tropsch production ( 2-3) This can be done by adding $\mathrm{CO}_{2}$ to the system enabling combined steam- and dry-reforming.

Finally, an important specific part of the process is studied in detail, namely char formation during evaporation and options to convert this char. During the evaporation stage, pyrolysis oil is converted into three main products: gas, vapor and char. The gas and vapor can be converted over a steam reforming catalyst but the char can potentially be detrimental for process operation and the overall efficiency. Char formation has to be either minimized or it has to be converted via combustion (to supply heat for the process) or alternatively it has to be gasified using steam and/or $\mathrm{CO}_{2}$. The amount of char being formed seems to be dependent on the applied heating rate during evaporation: the higher the heating rate the less char is formed. This can be attained by creating very small pyrolysis oil droplets via atomization. The formed char is very light/fluffy and needs to be well contacted and attached to a carrier to avoid elutriation from the reactors. The reactivity of the formed char is similar to biomass pyrolysis char, which is high enough for combustion but not high enough when internal steam gasification is envisaged.

A catalytically active material $(\mathrm{Ce}-\mathrm{Zr}-\mathrm{O})$ was developed onto which the char could be evenly deposited (under controlled conditions) and form molecular bonds between the char and the catalyst. The Ce-Zr-O catalyst provides oxygen to enhance char gasification and can be regenerated with both steam and $\mathrm{CO}_{2}$, allowing steam and $\mathrm{CO}_{2}$ gasification rates an order of magnitude higher than noncatalytic gasification. 


\section{Chapter 1}

\section{Introduction}

In this Thesis, research on steam reforming and gasification of biomass derived fast pyrolysis oil is described. Chapter 1 is divided into four main themes. First, the context of the research is discussed from a wide point of view. Secondly, reforming of pyrolysis oil is introduced including the envisaged benefits of this route. Thirdly, a literature summary is given on gasification/reforming starting from 'classical' gasification and ending with the development of steam reforming catalysts for pyrolysis oil fractions and model compounds. Finally, a brief overview is given on the content of the rest of the Thesis. 


\section{Introduction}

\subsection{Context of research}

To describe the context of the research actual facts are combined with personal views which, especially in this research area, can vary strongly from person to person.

In the coming decades, the way mankind will generate its heat, power and chemicals will shift drastically. Three different factors can be identified as the main drivers for this shift. The first one appeared in the 1970s which resulted in the first (1973) and second (1979) oil crises, namely the local concentration of large quantities of high quality liquid fossil fuel. At that time, political and economical conflicts disrupted the liquid fossil fuel market and created instant shortages in the Western countries. Up till today, conflicts still have a large impact on fossil fuel prices. Secondly, in the eighties and nineties concern about the environment and climate change initiated strong lobbies to create locally (mainly in cities) cleaner air and reduce fossil fuel consumption. Mankind has a too large 'footprint', and the rapid release of $\mathrm{CO}_{2}$ from fossil fuel contributes to a global warming. Thirdly, fossil fuel is exhaustible. Even though still large quantities are available and in the future new technologies and more favorable economics will allow extraction of difficult oil fields, the growing world population and its economic development more than balances this effect. The importance of these shift factors changes in time but are not phasing each other out. At the time of writing, countries strongly develop own strategies to ensure energy availability (combination of the first and third factor) which is often referred to as 'Security of Supply'.

Alternatives to fossil fuel consumption are available. Induced nuclear fission found its civil application a few years after the Second World War. Although there is a lot of nuclear energy available which avoids the release of greenhouse gases, its radioactive waste is a concern to society. Additionally, the fear of accidents and (terrorist) attacks creates a relatively high acceptance barrier of this technology. Controlled nuclear fusion is still in an embryonic development stage but could make a large new source of energy available.

Renewable or sustainable energy is seeing its rise in applications and various forms. However, exactly defining renewable and sustainable is difficult. Three proposed definitions are: 


\section{Sustainable development [1]}

'Sustainable development is development that meets the needs of the present without compromising the ability of future generations to meet their own needs'

Renewable energy resource [2]

'Energy flows which are replenished at the same rate as they are "used"

\section{Sustainable energy [3]}

'A dynamic harmony between the equitable availability of energy-intensive goods and services to all people and the preservation of the earth for future generations'

The first definition covers the integral problem while the last fits best to the challenges in energy provision. Renewable energy is often classified according to its extraction source and usable form:

- Nuclear fusion (from the Sun) $\rightarrow \quad$ solar, wind, hydro and biomass

- Nuclear fission $\rightarrow \quad$ geothermal, induced decay ${ }^{*}$

- Astronomical object interaction $\rightarrow$ tidal

${ }^{*}$ Not renewable in a strict sense, but in combination with a breeder reactor a very large source.

Solar, wind, hydro, geothermal, induced nuclear decay and tidal energy are used for the production of heat and power, which is very important in future scenarios where societies are on average expected to consume much more electricity both for in-house use and personal transportation. The variable availability (e.g. the sun does not shine all day, wind is weather dependent) and difficult storage of large quantities of electricity will be a challenge to ensure electricity on demand. Buffers, flexible electricity producing facilities and centrally programmed electricity consumption (for instance car battery charging) need to be developed.

Biomass is a flexible renewable energy source. Although its overall efficiency (sunlight to stored energy) is low, it is already produced and used at large quantities ( $\sim 13 \%$ of the world's energy production). It can be applied for heat and power, but moreover for the production of chemicals and transportation fuels. It is the only 


\section{Introduction}

renewable energy source which stores energy in molecular carbon bond structures which is highly needed when mankind's current consumption pattern is analyzed.

When looking at the transportation sector; after the 'hydrogen economy' now an 'electricity economy' seems to emerge [4]. However, this is mainly the case for personal or public transportation. A few transportation sectors will in the (near) future still depend on liquid fuels, namely the truck traffic, ships and aviation. This is because the energy needs to be stored very efficiently (MJ per unit volume) and liquid fuels are superior compared to any electricity or hydrogen storage options.

Biomass is already widely being used for food and feed production, as construction material, as combustion fuel and for chemicals and products (e.g. paper). When considering biomass to replace fossil fuels or more important (for now) decrease the increasing fossil fuel consumption, it should be taken into account that competition may occur with the abovementioned existing applications. Most known fear is that large scale biomass production will compete with the food production which besides an economical conflict also raises an ethical debate: whether fuels should be produced instead of food while not everybody in the world has enough access to food. It should then be considered that with the current biobased fuel production there is no shortage of food worldwide; political and economical reasons mainly limit wide availability and not so much the production capacity. Other concerns address possible ecological problems due to a decrease of biomass diversity and the amount of wildlife nature.

To convert biomass into products which can be used for chemical and fuel applications two major routes can be identified, namely biological conversion and thermo-chemical conversion. Complete reviews of both conversion routes are not available but good overview presentations are given by McMillan [5] and Bain [6] respectively.

\section{Biological conversion}

Sugars present in biomass can be fermentated to produce ethanol which is a base chemical or can be used as an additive (or replacement) for gasoline. The most used biomasses for this conversion are sugarcane, sugar beet, wheat and maize. In order to reach higher biomass conversions and to broaden the usable feedstocks, extensive development is undertaken to be able to ferment cellulose and hemicelluloses. 
Another already widely used biological application is gas production via anaerobic digestion of biomass waste streams and waste water. This gas mainly consists of methane and carbon dioxide. Even though the conversion of biomass to gas is not very high, a valuable byproduct residue is created which can often be used as a fertilizer.

\section{Thermo-chemical conversion}

Thermo-chemical conversion routes are envisaged to be able to deal with both whole biomass streams (e.g. lignocelluloses waste from agriculture) and certain fractions (e.g. lignin byproduct from biological conversions). Various products can then be created in gaseous, liquid or solid form. From a technological point of view, thermo-chemical routes allow connection to the petrochemical industry where elevated temperatures and pressures are normally used, often in combination with catalysts. An overview of thermo-chemical conversion routes from pretreatment to product is shown in Figure 1.1. 


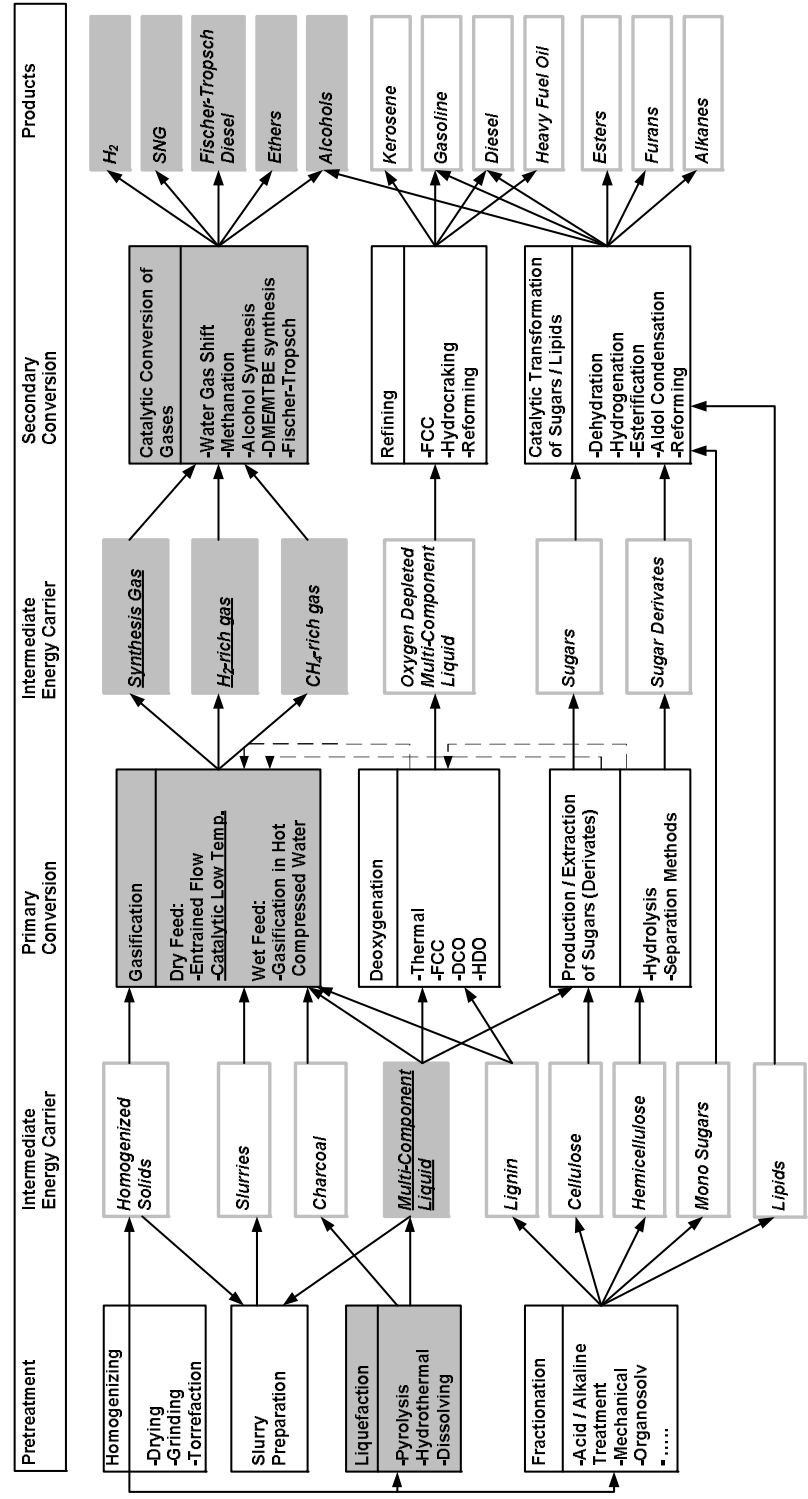

Figure 1.1. Overview of biomass thermo-chemical conversion routes.

The research described in this Thesis follows:

'Multi-Component Liquid' $\rightarrow$ 'Catalytic Low Temp.' $\rightarrow$ 'Synthesis gas $/ \mathrm{H}_{2}$-rich gas'.

The whole envisaged conversion route is marked grey. Modified from Kersten et al. [7]. 


\subsection{Conversion route: reforming via fast pyrolysis of biomass}

The route investigated in this work is a thermo-chemical process, namely the steam reforming and gasification of pyrolysis oil. Pyrolysis oil is an intermediate product which is produced from relatively dry biomass (waste). When biomass is heated in absence of oxygen it decomposes into three types of products: permanent gas, vapors/steam and char. The rate of heating, the process operating temperature and residence time will mainly determine the yields of the three products. Pyrolysis oil is the condensable fraction (vapors/steam) when a high heating rate and medium temperature $\left(\sim 500{ }^{\circ} \mathrm{C}\right)$ is applied in combination with a very short residence time. In this way, the pyrolysis oil yield can be maximized at $\sim 70 \mathrm{wt} \%$ with permanent gas and char being produced in roughly equal amounts. Lower temperatures will maximize char production (carbonization) and higher temperatures gas (gasification). The pyrolysis oil looks somewhat similar to heavy fuel oil, but is essentially different in its oxygent content, $\mathrm{pH}$ and heating value as illustrated in Table 1.1.

Table 1.1. Typical properties of wood pyrolysis oil and heavy fuel oil.

Modified from Czernik et al. [8].

\begin{tabular}{l|cc}
\hline \multicolumn{1}{l}{ Physical property } & Pyrolysis oil & Heavy fuel oil \\
\hline Moisture content (wt\%) & $15-30$ & 0.1 \\
pH & 2.5 & - \\
Specific gravity & 1.2 & 0.94 \\
Elemental composition (wt\%) & & \\
\multicolumn{1}{c}{ C } & $54-58$ & 85 \\
H & $5.5-7.0$ & 11 \\
$\quad$ N & $35-40$ & 1.0 \\
\multicolumn{1}{c}{ ash } & $0-0.2$ & 0.3 \\
HHV (MJ/kg) & $0-0.2$ & 0.1 \\
Viscosity (at 50 $\left.{ }^{\circ} \mathbf{C}, \mathbf{c P}\right)$ & $16-19$ & 40 \\
Solids (wt\%) & $40-100$ & 180 \\
\end{tabular}




\section{Introduction}

Although some energy is lost during the production, there are advantages for producing pyrolysis oil as an intermediate energy carrier compared to using biomass directly:

- A liquid is produced from usually difficult to handle bulky solid biomass. In this way, the volumetric energy density is increased roughly five times compared to the original source. This makes transport especially over longer distances much more effective.

- It can be stored in tanks. It is more stable against biological decomposition and can not ignite at ambient temperature.

- Pyrolysis oil is cleaner than the original feedstock. Minerals and metals are concentrated in the byproduct char with an option to recycle them back locally to the soil.

- Liquids are easier to process especially when pressurized conversions are envisaged.

With these advantages, a solution is being given for effectively utilizing biomass: to bridge the large gap of biomass supply and demand, and to do it in a sustainable way. Biomass is available decentralized (where it is being grown) but processing needs to be done centralized to benefit from the economy of scale. Pyrolysis oil can be produced where the biomass is available and then be transported over long distances (road, water) to central processing units of similar scales as the current petrochemical industry. Besides technical and logistic advantages, this conversion chain will also give incentives for economical development and job creation especially in rural areas.

The pyrolysis oil as such can not be used for high end applications and therefore has to be upgraded. Three main routes can be identified: direct upgrading of the liquid, extraction of specific components and gasification/steam reforming. In this Thesis, the gasification/steam reforming at relatively low temperatures $\left(500-850{ }^{\circ} \mathrm{C}\right)$ of pyrolysis oil is investigated. With gasification/steam reforming, the important gaseous platform chemicals: carbon monoxide, hydrogen and methane can be produced. There is an increasing demand for hydrogen in the current petrochemical industry and hydrogen will

be of paramount importance in the upgrading of various biomass-based feedstocks. A combination of hydrogen and carbon monoxide (synthesis gas or syngas) can be used for 
the production of ethers, alcohols and Fischer-Tropsch fuels. Methane can be used as a substitute natural gas $(\mathrm{SNG})$ in the gas grid.

The general overall stoichiometric reaction for gasification/steam reforming of pyrolysis oil can be written as:

$\mathrm{C}_{k} \mathrm{H}_{l} \mathrm{O}_{m}+\mathrm{aH}_{2} \mathrm{O} / \mathrm{CO}_{2} / \mathrm{O}_{2} \rightarrow \mathrm{CO}_{2}+\mathrm{CO}+\mathrm{H}_{2}+\mathrm{H}_{2} \mathrm{O}+\mathrm{CH}_{4}+\mathrm{C}_{2+}+$ Tars $+\mathrm{C}_{s}$

Important reactions are:

$$
\begin{array}{lc}
\mathrm{C}_{x} \mathrm{H}_{y} \mathrm{O}_{z}+(x-z) \mathrm{H}_{2} \mathrm{O} \rightarrow x \mathrm{CO}+\left(\frac{y}{2}+x-z\right) \mathrm{H}_{2} & \text { steam reforming } \\
\mathrm{C}_{x} \mathrm{H}_{y} \mathrm{O}_{z}+(x-z) \mathrm{CO}_{2} \rightarrow(2 x-z) \mathrm{CO}+\frac{y}{2} \mathrm{H}_{2} & \text { dry reforming } \\
\mathrm{C}_{x} \mathrm{H}_{y} \mathrm{O}_{z}+\left(x+\frac{y}{4}-\frac{z}{2}\right) \mathrm{O}_{2} \rightarrow x \mathrm{CO}_{2}+\frac{y}{2} \mathrm{H}_{2} \mathrm{O} & \text { combustion } \\
\mathrm{CO}+3 \mathrm{H}_{2} \leftrightarrow \mathrm{CH}_{4}+\mathrm{H}_{2} \mathrm{O} & \text { methanation } \\
\mathrm{CO}+\mathrm{H}_{2} \mathrm{O} \leftrightarrow \mathrm{CO}_{2}+\mathrm{H}_{2} & \text { water gas shift }
\end{array}
$$

A conceptual layout of the envisaged conversion process is illustrated in Figure 1.2. It requires energy which is mainly caused by the evaporation of the pyrolysis oil (especially the water) and the endothermic catalytic reforming reactions. Energy can be supplied externally (e.g. fuel combustion) or internally by adding oxygen to the process (autothermal reforming).

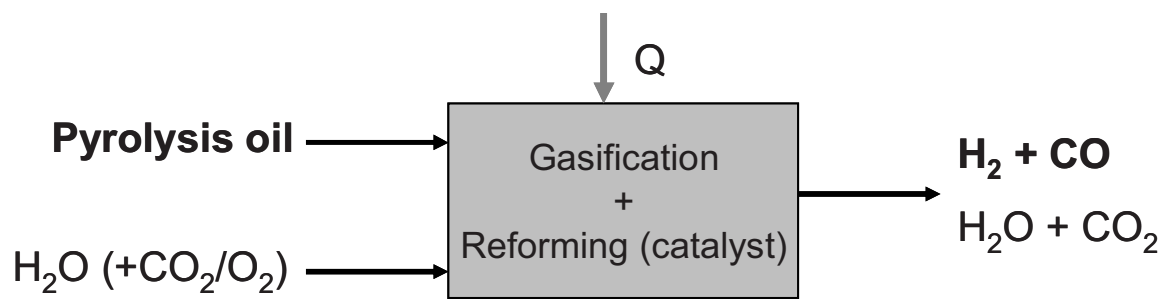

Figure 1.2. Simplified conversion route for the gasification/reforming of pyrolysis oil to produce syngas/hydrogen. 


\section{Introduction}

\subsection{Literature}

\subsubsection{Development of coal and oil gasification}

The development of commercial gasification started in 1812 with the founding of the London Gas, Light and Coke Company [9]. A fuel gas (also known as a producer or town gas) was produced from partial combustion of coal with air which was rich in $\mathrm{CO}, \mathrm{N}_{2}$, $\mathrm{CH}_{4}, \mathrm{H}_{2}$, and heavier hydrocarbons (tars). This gas was first used for illuminating populated areas and later also for heating and electricity production. The Siemens gasifier (1861) was the first continuously operated gasifier with spatially separate combustion and gasification sections. All early gasifiers used air-blown fixed bed reactors with a maximum gasification temperature of about $900{ }^{\circ} \mathrm{C}$. Winkler introduced the first lowtemperature fluidized bed gasifier in 1926. Its advantages over a fixed bed gasifier included the ability to accept all types of coal, even smaller sized coal pieces, and more ash removal flexibility.

The next advance was high pressure oxygen-blown gasification. The first oxygenblown moving bed gasifier (Lurgi, 1936) was operated at temperatures below $1000{ }^{\circ} \mathrm{C}$ to prevent ash melting. This system, in slightly modified form, is still in operation today (e.g. by Sasol). The Koppers-Totzek entrained flow gasifier began commercial operation in 1938. It continuously produced syngas $\left(\mathrm{CO}\right.$ and $\left.\mathrm{H}_{2}\right)$ containing no tars and methane at about $1850{ }^{\circ} \mathrm{C}$ and atmospheric pressure from oxygen-entrained coal. In the late $1940 \mathrm{~s}$ and early 1950s, Texaco and Shell (separately) developed oil gasification technologies, using entrained flow reactors with top-mounted burners (atomizers) operating at pressures of up to 80 bar and temperatures in the range of $1250-1500{ }^{\circ} \mathrm{C}$. Lurgi also developed oil gasification technology known as multipurpose gasification. During the oil crisis of the 1970s, development of coal gasification was renewed. Texaco and Shell (together with Krupp-Koppers) developed entrained flow, high pressure (20-70 bar), high-temperature $\left(>1400^{\circ} \mathrm{C}\right)$ coal gasification technology.

Modern entrained flow gasifiers are operated at elevated pressures (up to 80 bar), temperatures $>1250{ }^{\circ} \mathrm{C}$ and are designed for coal or oil applications. They are part of a refinery (mostly oil based) or stand alone (mostly coal based) and serve as suppliers for power, syngas/hydrogen and steam. A comprehensive overview of gasification is given by Higman and van der Burgt [9]. 


\subsubsection{Biomass/pyrolysis oil noncatalytic gasification}

Biomass gasification has been extensively studied from lab-scale to commercial application at low temperatures $\left(<950^{\circ} \mathrm{C}\right)$ using mostly fixed and (circulating) fluidized bed technology. Air was either added directly which results in product gas dilution with nitrogen or indirectly via circulating reactors to produce a higher heating value gas [9-12]. For complete reviews on gasification of dry biomass including reactor types, problems encountered ect. the reader is referred to Beenackers and Van Swaaij [13] and Maniatis [14].

The produced gas can either be used for heat and power generation or would need catalytic upgrading processes to produce a clean syngas for catalytic downstream conversion, which is the topic of the next section. If clean syngas is the desired product, only entrained flow gasification of biomass can directly meet these specifications noncatalytically similar to entrained coal and oil gasifiers.

Some entrained flow cogasification testing of dry biomass have been performed by oil companies. However, a complete set of data have not been published yet. A big challenge is to pretreat the biomass in such a way so that its particle size is small enough which is needed for entrained flow gasification where very short residence times are being used. Conventional cutting machines cannot reduce the size sufficiently but torrefaction (low temperature treatment of the biomass $\sim 200-300{ }^{\circ} \mathrm{C}$ ) before size reduction could be a solution [15].

Two entrained flow process concepts have been developed by adjusting either the process or the feed handling to biomass.

Choren [16] adjusted the process using a three stage gasifier. In the first stage, the biomass is fed to a low temperature gasifier/pyrolyser $\left(\sim 400-500{ }^{\circ} \mathrm{C}\right)$ and oxygen is added. The biomass is pyrolysed producing a gas/vapor mixture and char which are separated from each other. The gas vapor stream is fed to the second gasification step where by adding additional oxygen the temperature is raised to above $1400{ }^{\circ} \mathrm{C}$ resulting in a total conversion of the gas/vapor mixture to $\mathrm{H}_{2}, \mathrm{CO}, \mathrm{CO}_{2}$ and $\mathrm{H}_{2} \mathrm{O}$. In the third gasification section, the char is contacted with the hot gas mixture and then undergoes endothermic gasification lowering the temperature to $\sim 800^{\circ} \mathrm{C}$. In this process concept, the syngas is used for Fischer-Tropsch fuel production. 
The Forschungszentrum Karlsruhe (Karlsruhe, Germany) and Future Energy Company (Freiberg, Germany) have tested entrained flow gasification of biomass by using pyrolysis oil/char slurries as feedstock $[17,18]$. Firstly, the pyrolysis oil is produced decentralized from lignocellulose biomass waste (for instance wood and straw) using a twin screw Lurgi-Ruhrgas mixer reactor. The pyrolysis oil is then mixed with the byproduct char to create a slurry which can contain up to $25-30 \mathrm{wt} \%$ solids with a viscosity of 1-10 Pas. In this way, the Lower Heating Value (LHV) of the slurry product can be raised up to $25 \mathrm{MJ} / \mathrm{kg}$ which is much higher than conventional pyrolysis oil (LHV $\sim 15-18 \mathrm{MJ} / \mathrm{kg}$ ). The minerals and metals, which were separated during the pyrolysis process into the char, are reintroduced into the slurry. Entrained flow gasification can handle minerals and metals converting them into slag. At temperatures above $1200{ }^{\circ} \mathrm{C}$ and an equivalence combustion ratio $(\lambda)$ of $33 \%$, a tar free and low methane raw syngas was produced of which the data are presented in Table 1.2. The process and the concept of the route is currently further being improved and evaluated.

Table 1.2. Typical results from entrained flow gasification of a pyrolysis oil/char slurry.

Modified from Dinjus et al. [18].

\begin{tabular}{|c|c|c|c|}
\hline \multirow{2}{*}{\multicolumn{2}{|c|}{$\begin{array}{r}\text { Elemental analysis } \\
(\mathrm{wt} \%)\end{array}$}} & \multicolumn{2}{|c|}{ Syngas analysis } \\
\hline & & (vol\%) & raw \\
\hline $\mathrm{C}$ & 58.4 & $\mathrm{CO}_{2}$ & 16.4 \\
\hline H & 6.8 & $\mathbf{H}_{2}$ & 31.2 \\
\hline $\mathbf{N}$ & 0.3 & $\mathbf{O}_{2}$ & 0.0 \\
\hline $\mathbf{O}$ & 34.1 & $\mathbf{N}_{2}$ & 4.0 \\
\hline \multirow[t]{3}{*}{$\mathbf{S}$} & $<0.05$ & $\mathrm{CH}_{4}$ & 0.1 \\
\hline & & $\mathrm{CO}$ & 48.3 \\
\hline & $(\mathrm{MJ} / \mathrm{kg})$ & & \\
\hline LHV & 21.1 & & \\
\hline
\end{tabular}

At low temperatures, only lab experiments have been performed with noncatalytic gasification of pyrolysis oil. At the University of Saskatchewan (Saskatchewan, Canada) pyrolysis oil was gasified in a quartz fixed bed (2-3 $\mathrm{mm}$ size) reactor at temperatures between $650-800{ }^{\circ} \mathrm{C}$, of which averaged results are shown in Table $1.3[19,20]$. The run duration time was limited to 30-60 min due to solid build up in the fixed bed. With 
increasing temperature, the conversion of pyrolysis oil shifted more to permanent gases at the expense of liquids. Very high concentrations of $\mathrm{CH}_{4}$ and remarkably also $\mathrm{C}_{2}-\mathrm{C}_{3}$ were measured. These high $\mathrm{C}_{2}-\mathrm{C}_{3}$ concentrations were, to the best of our knowledge, not measured before in related biomass gasification work and also not in the work presented in this Thesis. It was concluded that by varying reactor temperature, inert gas flow, $\mathrm{CO}_{2}$ gas flow, $\mathrm{H}_{2}$ gas flow, and/or steam flow the composition of the gas can be steered towards hydrogen-rich and carbon monoxide-rich and medium-heating-value gas production.

Table 1.3. Noncatalytic gasification of pyrolysis oil in a fixed bed reactor.

Modified from Panigrahi et al. [19].

\begin{tabular}{c|cccc}
\hline $\begin{array}{c}\text { Gas composition } \\
(\mathrm{mol} \%), 30 \text { min run }\end{array}$ & 650 & 700 & 750 & 800 \\
\hline $\mathbf{H}_{\mathbf{2}}$ & 12.8 & 16.3 & 9.3 & 12.8 \\
$\mathbf{C O}$ & 17.0 & 9.2 & 6.5 & 7.7 \\
$\mathbf{C O}_{2}$ & 2.5 & 3.4 & 2.1 & 2.6 \\
$\mathbf{C H}_{\mathbf{4}}$ & 19.2 & 21.6 & 23.2 & 9.0 \\
$\mathbf{C}_{\mathbf{2}}-\mathbf{C}_{\mathbf{3}}$ & 37.9 & 40.4 & 46.9 & 40.3 \\
$\mathbf{C}_{\mathbf{4 +}}$ & 10.1 & 9.1 & 12.0 & 9.0 \\
\hline
\end{tabular}

Conversion of pyrolysis oil to products

\begin{tabular}{c|llll}
\multicolumn{5}{c}{$(\mathrm{wt} \%), 1$ h run } \\
\hline Gas & 32 & 38 & 51 & 51 \\
Liquid (incl. $\left.\mathbf{H}_{2} \mathbf{O}\right)$ & 39 & 37 & 19 & 17 \\
Char & 25 & 22 & 27 & 30
\end{tabular}

\subsubsection{Biomass catalytic gasification/steam reforming}

In order to produce a clean tar and methane free syngas at low process temperatures $\left(<950^{\circ} \mathrm{C}\right)$, various research groups have studied the application of catalysts to biomass gasification. Lowering the temperature of the gasifier below the weakening temperature of the ashes reduces equipment costs and allows for gasification at smaller scale compared to entrained flow gasification. 


\section{Introduction}

Catalysts are either pre-mixed with the biomass, used (partly or fully) as bed material in fluid bed gasifiers or applied downstream of the gasifier for product gas upgrading.

Cheap disposable catalysts have been used to create an upgraded fuel gas rather than to produce actual syngas. Dolomite [21-24] has gained the most attention as it is very cheap. It is applied inside the gasifier to promote direct tar cracking or separately in a bed downstream of the gasifier. Although its calcined form can almost fully convert tars it is more often used as a tar-reducer, a guard material, allowing the usage of more active but also more sensitive catalysts downstream [25]. However, dolomite is not able to effectively convert methane and suffers from attrition [24,26]. Olivine [26,27] is much more resistant to attrition than dolomite with a somewhat lower activity for tar destruction. Impregnation of the olivine with nickel is possible to enhance its activity while maintaining its strength [28]. Alkali metals are most effective when impregnated onto the biomass promoting a tar free gas production, especially when potassium carbonate is being used. Catalyst deactivation, catalyst make-up and fluidization problems still need a lot of research attention before these catalysts could be effectively applied [21].

When besides tars also complete methane conversion is desired, high steam (and dry) reforming activity of the catalyst is of vital importance. Nickel on alumina based catalysts have been used in the industry for naphtha and natural gas reforming for many years and it was therefore also logical to test them for biomass gasification applications. Caballero et al. [25] and Simell et al. [29] have been able to effectively eliminate the tars in the biomass derived gas and realizing a significant decrease of methane using crushed and/or as-received commercial catalyst or dedicated monolith beds. For complete tar and methane elimination, only downstream secondary reactors after the gasifier have been successful in creating a clean gas. However, up till now none of the proposed processes have reached commercialization.

1.3.4 Catalytic gasification/steam reforming of pyrolysis oil (fractions and model compounds)

The research of gasification/steam reforming of pyrolysis oil was initiated by the National Renewable Energy Laboratory (NREL) in the USA. In the nineties of the $20^{\text {th }}$ century, the NREL published the first results [30] on steam reforming of acetic acid 
(HAc) and hydroxyacetaldehyde (HAA) with the aim to produce hydrogen. HAc and HAA were chosen as model compounds because they represent a part of the pyrolysis oil, which was identified as a possible renewable biomass chemical and energy carrier. A fixed bed microreactor was used to convert the model compounds using grounded commercial catalysts (G-90C and C18HC from United Catalysts Inc.). HAc was found to be slightly coking while HAA forms more coke. The thermal stability of the compounds was given as an indicator for coke formation. Both HAc and HAA were catalytically converted to a hydrogen rich gas at a reactor temperature $\sim 700{ }^{\circ} \mathrm{C}$ (for HAA a lower inlet temperature was chosen) and a steam over carbon ratio $(\mathrm{S} / \mathrm{C}) \geq 2$. Further tests with model compound reforming [31,32], including the vapors of cellulose, xylan and lignin, spraying of glucose, xylose and sucrose onto a fixed catalytic bed in combination with catalyst screening ultimately led to the first actual reforming of the aqueous soluble phase of pyrolysis oil [33]. The aqueous soluble phase of pyrolysis oil was chosen to be steam reformed to hydrogen because it was a side product in a proposed biorefinery concept to produce phenolic resins, as shown in Figure 1.3.

Two commercial naphtha/ $\mathrm{C}_{2}-\mathrm{C}_{3}$ steam reforming catalysts (UCI G90C and the ICI 46-series) showed very promising results in their ability to convert the aqueous soluble phase of pyrolysis oil with only minor coking at high steam over carbon ratios (20-30) [33]. However, an increase of methane concentration during a test could be observed. To feed the aqueous soluble phase of pyrolysis oil, adjustments had to be made to the atomizer system in order to directly add the reactant to the catalytic bed. This adjustment had to be made because (i) not all the pyrolysis oil (or its aqueous soluble phase) can be evaporated (ii) the mixture is thermally unstable and pre-charring has to be avoided. With the improvement of the feeding system, fixed bed reforming of the aqueous soluble phase of pyrolysis oil was still limited to 3-4 hours of operation due to carbonaceous deposits on the catalyst and in the freeboard [35]. To overcome this run time barrier, the reactor bed was changed from a fixed to a bubbling fluidized bed where the commercial catalyst was grounded to a particle size of $300-500 \mu \mathrm{m}$. A different catalyst than the ones used before, namely the naphtha reforming catalyst C11-NK from Süd-Chemie, was now being used. It was not explained/reasoned why the type of catalyst was changed. The liquid feed was added to the reactor via an externally water cooled atomizer system which was either vertically or horizontally placed [34,35]. The aqueous 
pyrolysis oil fraction was readily reformed in the fluidized bed of which the experimental data are given in Table 1.4 (most results are read from figures from articles or are recalculated from the data given in the article and therefore are estimated values).

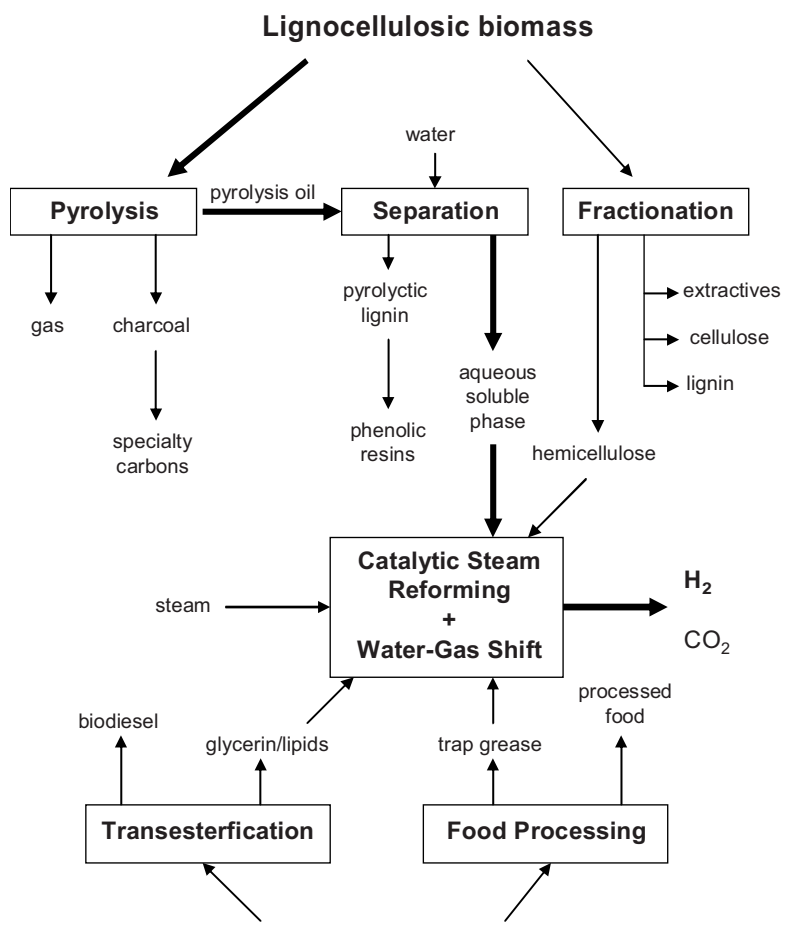

Plant \& animal fats

Figure 1.3. Proposed bio-refinery network by NREL which includes the reforming of the aqueous phase of pyrolysis oil. Modified from Czernik et al. [34].

Besides catalyst attrition (5\%/day), also some catalyst deactivation was observed leading to a rising methane concentration which leveled off at roughly $2.5 \mathrm{vol} \%$. Additionally, methane coreforming experiments were done where, at coreforming conditions, two times less unconverted methane was observed than when only methane was being steam reformed.

From this pioneering research related to pyrolysis oil reforming, two new research lines evolved: 
- Creating new catalysts which have a high activity to specifically (steam) reform oxygenated compounds.

- Creating attrition resistant fluidizable catalysts.

Both research lines, which were also investigated by the NREL, are covered in the next section.

From 2005 [37-39], the NREL started research on a new route to produce hydrogen from pyrolysis oil. This time, the whole pyrolysis oil is used after stabilization with $10 \mathrm{wt} \%$ of methanol. The concept consists of consecutive volatilization $\left(\sim 400{ }^{\circ} \mathrm{C}\right)$, oxidative cracking $\left(\sim 650{ }^{\circ} \mathrm{C}\right.$, addition of oxygen) and autothermal catalytic conversion to hydrogen (addition of steam), see also Figure 1.4. The hydrogen is separated using a supported membrane from the $\mathrm{H}_{2} \mathrm{O}, \mathrm{CO}, \mathrm{CH}_{4}$, and $\mathrm{CO}_{2}$ and the residual gas is combusted to supply the heat for the process.

After the pyrolysis oil is evaporated, the vapors are further oxidized. These oxidized vapors are then highly reactive and easily converted by the steam reforming catalyst at a relative low temperature. In this way, secondary and tertiary tar formation should be minimized. The start of the research consist of studying (i) the impact of the oxidation step of the vapors (ii) steam reforming of methanol stabilized pyrolysis oil in the 'conventional' fluidized bed setup. At the time of writing, only the results of steam reforming of methanol stabilized pyrolysis oil have been published in open literature [39] with a $\mathrm{S} / \mathrm{C}$ ratio $\sim 5.8$. The pyrolysis oil could be readily steam reformed to permanent gases, see also Table 1.4. However, during the experiment a steadily rising methane production was observed.

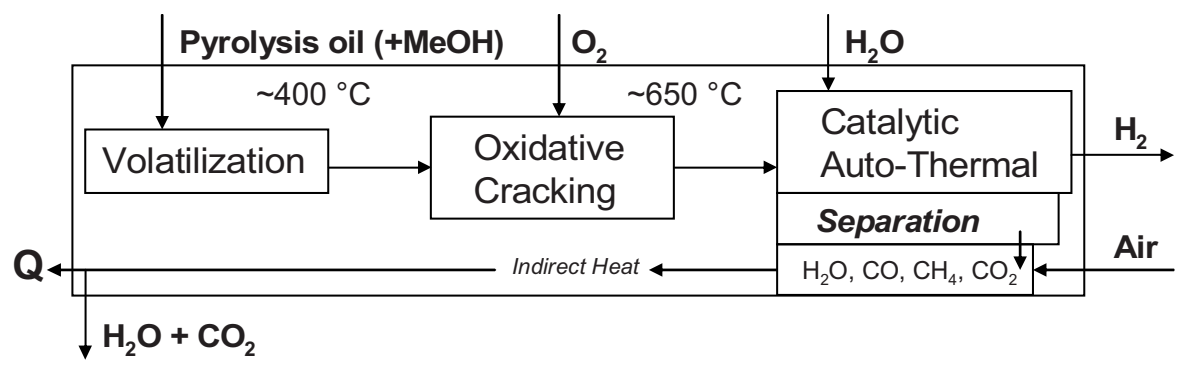

Figure 1.4. Proposed route to convert methanol stabilized pyrolysis oil to hydrogen.

Modified from Evans et al. [38]. 
Introduction

Table 1.4. Results from reforming of the aqueous soluble phase of pyrolysis oil as presented in $[34,36,39]$. The definitions are given in Chapter 2.

\begin{tabular}{|c|c|c|}
\hline Bed type & C11-NK & C11-NK \\
\hline Feed type & $\begin{array}{c}\text { Aqueous soluble } \\
\text { phase of pyrolysis oil }\end{array}$ & $\begin{array}{c}\text { pyrolysis oil } \\
\text { (10 wt } \% \text { methanol) }\end{array}$ \\
\hline Temperature $\left({ }^{\circ} \mathrm{C}\right)$ & 850 & 850 \\
\hline $\mathrm{S} / \mathrm{C}$ ratio, molar & 7.1 & 5.8 \\
\hline$\lambda(\%)$ & 0 & 0 \\
\hline Duration experiment (h) & 90 & 10 \\
\hline Carbon to gas (\%) & 95 & 95 \\
\hline H2 yield (\%) & 76 & 85 \\
\hline \multicolumn{3}{|l|}{ Gas production $\left(\mathrm{Nm}^{3} / \mathrm{kg}\right)$} \\
\hline $\mathbf{H}_{2}$ & 1.61 & n.d. \\
\hline $\mathrm{CH}_{4}$ & 0.06 & n.d. \\
\hline $\mathrm{CO}$ & 0.21 & n.d. \\
\hline $\mathrm{CO}_{2}$ & 0.70 & n.d. \\
\hline $\mathrm{C}_{2}-\mathrm{C}_{3}$ & n.d. & n.d. \\
\hline \multicolumn{3}{|l|}{ Gas composition (vol\%) } \\
\hline $\mathbf{H}_{2}$ & 62.5 & 72 \\
\hline $\mathrm{CH}_{4}$ & 2.5 & $0.2-1.0$ \\
\hline $\mathrm{CO}$ & 8.0 & 8.0 \\
\hline $\mathrm{CO}_{2}$ & 27.0 & 21.0 \\
\hline $\mathrm{C}_{2}-\mathrm{C}_{3}$ & n.d. & n.d. \\
\hline
\end{tabular}

\subsubsection{Steam reforming catalyst development for oxygenates of pyrolysis oil}

Commercially, methane and to a much smaller extend naphtha are catalytically converted to syngas/hydrogen via steam reforming, partial oxidation or a combination of the two (autothermal reforming) [40,41]. To enhance steam and dry reforming reactions at low temperatures $\left(<900{ }^{\circ} \mathrm{C}\right)$ nickel on alumina based catalysts are applied. The 
catalysts have been optimized for each specific feed and process condition by varying nickel loadings and promotion of the catalyst with for instance potassium or magnesium.

Since, besides the feed, the mechanism of steam reforming oxygenated compounds is different [42], many research groups have been trying to develop new catalyst formulations using model compounds of pyrolysis oil and the aqueous phase of pyrolysis oil to produce hydrogen/syngas while minimizing coke formation. A summary of the research is given in Table 1.5. Although noble compounds (especially Rh) were found to give high activities and stabilities, $\mathrm{Ni}$ is still preferred. $\mathrm{Ni}$ is a relatively cheap metal and it is capable to fit both steam and dry reforming and to activate water [50]. Besides commercial applied promoters ( $\mathrm{K}$ and $\mathrm{Mg}$ ), $\mathrm{La}, \mathrm{Ce}$, and $\mathrm{Zr}$ show promising results either as a promoter or as a new support. A detailed review and experimental results on new catalyst development for steam reforming oxygenated compounds present in pyrolysis oil can be found in the Ph.D. Thesis of Berta Matas Güell [57], who did research parallel to our work on this topic.

In a fluidized bed reactor, as proposed by the NREL to convert pyrolysis oil or its fractions, besides catalytic activity the mechanical strength will be very important. Unlike Fluid Catalytic Cracking (FCC) catalysts where the catalyst is a single structure, steam reforming catalysts have a metal supported on a carrier with promoters which makes the catalyst much more vulnerable for attrition. Tests in a fluidized bed with crushed commercial steam reforming catalysts (Sud Chemie C11-NK and ICI 46-1 S) showed a weight loss due to attrition of $28-33 \%$ after 48 hours of testing [36].

Stronger fluidizable steam reforming catalysts have been developed both for pyrolysis oil (or its fractions) and for biobased fuel gases. NREL and CoorsTek developed pure (99.5 wt \%) alumina and alumina based ( $\geq 90 \mathrm{wt} \%$, rest being $\mathrm{MgO}, \mathrm{SiO}_{2}$ and $\mathrm{K}_{2} \mathrm{O}$ ) fluidizable supports which had a lower surface area than commercial ones $\left(1.4-2.7 \mathrm{~m}^{2} / \mathrm{g}\right.$ versus $9.7 \mathrm{~m}^{2} / \mathrm{g}$ commercial) but a very low attrition rate $(0.01 \mathrm{wt} \% / \mathrm{h}$ versus $0.41-0.69$ $\mathrm{wt} \% / \mathrm{h}$ commercial). The catalysts showed some deactivation when steam reforming the aqueous fraction of pyrolysis oil [36] and ethylene/benzene [58]. 
Introduction

Table 1.5. Overview of catalyst development for the steam reforming of model compounds of pyrolysis oil and the aqueous phase of pyrolysis oil.

\begin{tabular}{|c|c|c|c|c|}
\hline Metal & Support/promotion & Compound & Bed type & Reference \\
\hline $\begin{array}{c}\text { Ru, Ni, Pt, } \\
\text { Pd, Rh }\end{array}$ & $\begin{array}{c}\mathrm{Al}_{2} \mathrm{O}_{3}, \mathrm{La}_{2} \mathrm{O}_{3}, \mathrm{MgO} \\
\mathrm{CeO}_{2}\end{array}$ & Acetic Acid & Packed & [43] \\
\hline $\mathrm{Ni}$ & $\mathrm{Al}_{2} \mathrm{O}_{3}$ & Acetic Acid & Packed & [44] \\
\hline $\mathrm{Ni}$ & $\mathrm{Al}_{2} \mathrm{O}_{3}, \mathrm{~K} / \mathrm{La}_{2} \mathrm{O}_{3}$ & Acetic acid, Pyrolysis oil ${ }^{\mathrm{a}}$ & Packed & {$[45,46]$} \\
\hline $\mathrm{Pt}, \mathrm{Rh}$ & $\mathrm{Ce}_{0.5} \mathrm{Zr}_{0.5} \mathrm{O}_{2}$ & Pyrolysis oil & $\begin{array}{c}\text { Packed } \\
\text { Monolith }\end{array}$ & [47] \\
\hline $\mathrm{Rh}$ & $\mathrm{MgO}, \mathrm{Mg}-\mathrm{Ce}-\mathrm{Zr}-\mathrm{O}$ & Phenol & Packed & [48] \\
\hline $\mathrm{Ni}$ & Olivine & Ethylene glycol & Fluidized & [49] \\
\hline $\mathrm{Ni}$ & $\mathrm{ZrO}_{2}, \mathrm{~K}, \mathrm{La}$ & Acetic Acid & Packed & {$[50]$} \\
\hline $\mathrm{Rh}, \mathrm{Pt}$ & $\mathrm{Al}_{2} \mathrm{O}_{3}, \mathrm{SiO}_{2}, \mathrm{Ce}, \mathrm{La}$ & $\begin{array}{c}\text { Ethyl Propionate, Ethyl } \\
\text { Lactate, Propionic Acid, } \\
\text { Lactic Acid }\end{array}$ & Monolith & [51] \\
\hline $\mathrm{Pt}$ & $\mathrm{ZrO}_{2}$ & Acetic Acid & Packed & {$[42,52]$} \\
\hline- & $\begin{array}{c}\mathrm{C} 12 \mathrm{~A} 7-\mathrm{O}-, \mathrm{MgO} \\
\mathrm{KHCO}_{3}, \mathrm{CeO}_{2}\end{array}$ & $\begin{array}{c}\text { Volatile fraction } \\
\text { pyrolysis oil }\end{array}$ & Packed & [53] \\
\hline $\mathrm{Ni}$ & $\mathrm{Al}_{2} \mathrm{O}_{3}, \mathrm{La}_{2} \mathrm{O}_{3}, \mathrm{Co}$ & Acetic Acid, Acetol & Fluidized & $\begin{array}{l}{[54]} \\
{[55]}\end{array}$ \\
\hline $\mathrm{Pt}, \mathrm{Rh}, \mathrm{Pd}$ & $\mathrm{Al}_{2} \mathrm{O}_{3}, \mathrm{CeZrO}_{2}$ & $\begin{array}{c}\text { Acetic Acid, Acetone, } \\
\text { Ethanol, Phenol, Aqueous } \\
\text { fraction pyrolysis oil }\end{array}$ & Packed & [56] \\
\hline $\mathrm{Ni}$ & $\mathrm{Al}_{2} \mathrm{O}_{3}, \mathrm{Mg}, \mathrm{Ca}, \mathrm{K}$ & $\begin{array}{c}\text { Aqueous fraction } \\
\text { pyrolysis oil }\end{array}$ & Fluidized & [36] \\
\hline
\end{tabular}

${ }^{\mathrm{a}}$ Sequential catalytic cracking is investigated instead of steam reforming.

The mineral olivine, which mostly contains $\mathrm{SiO}_{4}, \mathrm{Mg}$ and $\mathrm{Fe}$ with trace elements of $\mathrm{Ni}, \mathrm{Ca}, \mathrm{Al}$, and $\mathrm{Cr}$, has been proposed as support for nickel based steam reforming catalysts by Courson et al. $[59,60]$. The mineral has superior strength and a mild catalytic activity of its own. When the calcination temperature for $\mathrm{NiO}$ on olivine is varied three different connections can be made: (i) the $\mathrm{Ni}$ is freely deposited onto the support $\left(\sim 900{ }^{\circ} \mathrm{C}\right)$ (ii) the $\mathrm{Ni}$ is strongly linked to the olivine $\left(\sim 1100{ }^{\circ} \mathrm{C}\right)$ and (iii) the $\mathrm{Ni}$ is integrated in the olivine structure $\left(\sim 1400{ }^{\circ} \mathrm{C}\right)$. The Ni-olivine which was calcined at 
$1100{ }^{\circ} \mathrm{C}$ was found to be the most active for dry reforming of methane [60]. The catalyst was also tested in a pilot plant biomass bubbling gasifier where it showed a higher tar conversion relative to normal olivine as shown in Table 1.6 [61]. However, especially the methane was still present in high amounts. The attrition rate of the Ni-olivine was around $0.025 \mathrm{~kg} / \mathrm{kg}$ of dry fuel.

Table 1.6. Biomass pilot plant gasification results with olivine and Ni-olivine as bed material. Modified from Pfeifer et al. [61].

\begin{tabular}{c|cc}
\hline & Olivine & Ni-olivine \\
\hline Temperature $\left({ }^{\circ} \mathbf{C}\right)$ & 850 & 838 \\
Steam/Fuel $\left(\mathbf{k g}_{\mathbf{H} 20} / \mathbf{k g}_{\text {dry fuel }}\right)$ & 0.63 & 0.63 \\
Dry gas composition (vol\%) & & \\
$\mathbf{H}_{\mathbf{2}}$ & 38.9 & 43.9 \\
$\mathbf{C O}$ & 29.1 & 27.2 \\
$\mathbf{C O}_{2}$ & 17.5 & 18.8 \\
$\mathbf{C H}_{4}$ & 11.4 & 8.3 \\
$\mathbf{C}_{\mathbf{2}} \mathbf{H}_{\mathbf{4}}$ & 2.0 & 1.3 \\
$\mathbf{L H V}$ of product gas $\left(\mathbf{M J} / \mathbf{N m}{ }^{3}\right)$ & 13.8 & 12.4 \\
Gas production $\left(\mathbf{N m}^{3} / \mathbf{k g}\right)$ & 0.95 & 0.99 \\
Tar production $\left(\mathbf{g} / \mathbf{N m}^{3}, \mathbf{d r y} \mathbf{g a s}\right)$ & 12.7 & 1.2
\end{tabular}

Glass-ceramic catalysts have been proposed by Felix et al. [62]. Via controlled crystallization of a mixed melt (in the case for steam reforming $\mathrm{Li}_{2} \mathrm{O}-\mathrm{Al}_{2} \mathrm{O}_{3}-\mathrm{SiO}_{2}$ with $15 \mathrm{wt} \% \mathrm{NiO}$ and traces of $\mathrm{MgO}$ ) a very strong material is produced which is claimed to be more resistant to attrition than olivine. Steam reforming of an artificial syngas (vol\%: $16 \mathrm{H}_{2}, 8 \mathrm{CO}, 12 \mathrm{CO}_{2}, 4 \mathrm{CH}_{4}, 16 \mathrm{H}_{2} \mathrm{O}, 44 \mathrm{~N}_{2}$ and 600-700 ppmv of naphthalene) resulted in a 'steady-state' relative conversion of $\sim 70-80 \%$ naphthalene and $5-10 \%$ methane at $800{ }^{\circ} \mathrm{C}$.

At the time of writing, no fluid bed catalyst has been developed which has a similar activity and stability compared to fixed bed catalysts. 


\section{Introduction}

\subsection{Content of the Thesis}

In the previous sections of this Chapter an overview has been given of the research context and a summary of literature starting from 'classical' gasification to catalytic gasification/steam reforming of pyrolysis oil.

In Chapter 2 both catalytic and noncatalytic gasification of pyrolysis oil in a fluidized bed are studied. The whole pyrolysis oil was converted over a wide temperature range (523-914 ${ }^{\circ} \mathrm{C}$ ) and besides steam also air addition experiments were done. From the results of this work, a few disadvantages evolved from using a single bed reactor and a staged reactor concept was proposed and tested.

Chapter 3 continues the process development with a thorough study of the staged system which consists out of a fluidized bed followed by a fixed catalytic bed. The impact of temperature (both beds), catalyst loading and the steam over carbon ratio is studied. Besides different pyrolysis oil batches, also sugar waste streams are converted. A process model is made and the impact of commercial operating conditions and different modes of supplying heat to the process are investigated. Two Appendices are related to this Chapter. In the first Appendix results are given of steam reforming of vapors/gases produced during commercial charcoal production. In the second Appendix a model is described where steam reforming of pyrolysis oil is integrated with high temperature fuel cells.

Chapter 4 deals with the evaporation of the pyrolysis oil and the kind of char that is formed during this process. The influence of heating rate, temperature and exposure time on the product distribution (gas, vapor and char) during pyrolysis oil evaporation is investigated. From produced chars, the structure and the reactivity towards combustion and steam gasification is analyzed.

In Chapter 5, a catalytically active material (Ce-Zr-O) is tested for its ability to enhance char reactivity for combustion and steam and $\mathrm{CO}_{2}$ gasification in the evaporation section. A detailed analysis is made how char can deposit on the $\mathrm{Ce}-\mathrm{Zr}-\mathrm{O}$ and how molecular bonds are created between the char and the $\mathrm{Ce}-\mathrm{Zr}-\mathrm{O}$. The obtained reaction rates are compared to noncatalytic data and a mechanism for the conversion is proposed. 
Chapter 1

Finally, an outlook from the work is presented where the conversion route is placed in a broader perspective and an inventory is made what relevant research should be done to further develop this technology. 


\section{Introduction}

\section{References}

1. United Nations World Commission on Environment and Development (Brundtland, G.H.) Our Common Future, Oxford University Press, UK, 1987.

2. Sorensen, B. Renewable Energy, $2^{\text {nd }}$ edition, Academic Press, UK, 2000.

3. Tester, J.W.; Drake, E.M.; Driscoll, M.J.; Golay, M.W.; Peters, W.A. Sustainable energy: choosing among options, ed. Tester, J.W. MIT Press, USA, 2005.

4. Friedman, T.L. Hot, Flat and Crouwded: Why we need a green revolution - and how it can renew America ( $1^{\text {st }}$ edition), Farrar, Straus and Giroux, USA, 2008.

5. McMillan, J.D. Biotechnological Routes to Biomass Conversion. DOE/NASULGC Biomass \& Solar Energy Workshops, August 3-4, 2004.

www.nrel.gov/docs/gen/fy04/36831g.pdf, (last accessed $5^{\text {th }}$ of July 2009)

6. Bain, R.L. An Introduction to Biomass Thermochemical Conversion. DOE/NASULGC Biomass \& Solar Energy Workshops, August 3-4, 2004.

www.nrel.gov/docs/gen/fy04/36831e.pdf, (last accessed $5^{\text {th }}$ of July 2009)

7. Kersten, S.R.A.; Van Swaaij, W.P.M.; Lefferts, L.; Seshan, K. Options for Catalysis in the Thermochemical Conversion of Biomass into Fuels, In: Catalysis for Renewables: From Feedstock to Energy Production, ed. Centi, G.; Van Santen, R.A., Wiley-VCH, Weinheim, Germany, 2007.

8. Czernik, S.; Bridgwater, A.V. Overview of Applications of Biomass Fast Pyrolysis Oil Energy \& Fuels 2004, 18, 590.

9. Higman, C.; Van der Burgt, M. Gasification (2 ${ }^{\text {nd }}$ edition); Elsevier Science: New York, 2008.

10. Kersten, S.R.A.; Prins, W.; Van der Drift, A.; Van Swaaij, S.R.A. Experimental factfinding in CFB biomass gasification for ECN's $500 \mathrm{~kW}$ (th) pilot plant. Ind. Eng. Chem. Res. 2003, 42, 6755. 
11. Narváez, I.; Orío, A.; Aznar, M.P.; Corella, J. Biomass Gasification with Air in an Atmospheric Bubbling Fluidized Bed. Effect of Six Operational Variables on the Quality of the Produced Raw Gas. Ind. Eng. Chem. Res. 1996, 35, 2110.

12. Van der Meijden, C.M.; Veringa, H.J.; Van der Drift, A.; Vreugdenhil, B.J. The 800 KWth allothermal biomass gasifier Milena. Proceedings of the $16^{\text {th }}$ European Biomass Conference and Exhibition; Valencia, Spain, June 2-6, 2008, 711.

13. Beenackers, A.A.C.M.; Van Swaaij, W.P.M. Proceedings of the $1^{\text {st }}$ Eur. Workshop on thermochemical processing of biomass, Butterworths, 1984.

14. Maniatis, K. Progress in biomass gasification: an overview. In: A.V. Bridgwater (ed.) Progress in thermochemical biomass conversion, volume 1. Blackwell Science Ltd. UK, $2001,1$.

15. Zanzi, R.; Majari, M.; Björnborn, E. Biomass pre-treatment by torrefaction. Proceedings of the $16^{\text {th }}$ European Biomass Conference and Exhibition; Valencia, Spain, June 2-6, $2008,37$.

16. Choren GmbH, www.choren.com, (last accessed $29^{\text {th }}$ of June 2009)

17. Henrich, E.; Weirich, F. Pressurized Entrained Flow Gasification. Environmental Engineering Science 2004, 21, 53.

18. Dinjus, E.; Henrich, E.; Schingnitz, M. Syngas from the gasification of biomass slurries A progress report-. Proceedings of the $14^{\text {th }}$ European Biomass Conference, Paris, France, October 17-21, 2004, 1663.

19. Panigrahi, S.; Chaudhari, S.T.; Bakhshi, N.N.; Dalai, A.K. Production of Synthesis Gas/High-Btu Gaseous Fuel from Pyrolysis of Biomass-Derived Oil. Energy \& Fuels $2002,16,1392$.

20. Panigrahi, S.; Dalai, A.K.; Chaudhari, S.T.; Bakhshi, N.N. Synthesis Gas Production from Steam Gasification of Biomass-Derived Oil. Energy \& Fuels 2003, 17, 637. 


\section{Introduction}

21. Sutton, D.; Kelleher, B.; Ross, J.R.H. Review of literature on catalysts for biomass gasification. Fuel Processing Technology 2001, 73, 155.

22. Corella, J.; Orío, A.; Aznar, M.P. Biomass gasification with air in fluidized bed: Reforming of the gas composition with commercial steam reforming catalysts. Ind. Eng. Chem. Res. 1998, 37, 4617.

23. Olivares, A.; Aznar, M.P.; Caballero, M.A.; Gil, J.; Francés, E.; Corella, J. Biomass gasification: product gas upgrading by in-bed use of dolomite. Ind. Eng. Chem. Res. $1997,36,5220$.

24. Corella, J.; Aznar, M.P.; Gil, J.; Caballero, M.A. Biomass gasification in fluidized bed: where to locate the dolomite to improve gasification? Energy \& Fuels 1999, 13, 1122.

25. Caballero, M.A.; Corella, J.; Aznar, M.P.; Gil, J. Biomass gasification with air in fluidized bed. Hot gas cleanup with selected commercial and full-size nickel-based catalysts. Ind. Eng. Chem. Res. 2000, 39, 1143.

26. Rapagnà, S.; Jand, N.; Kiennemann, A.; Foscolo, P.U. Steam-gasification of biomass in a fluidised-bed of olivine particles Biomass and Bioenergy 2000, 19, 187.

27. Corella, J.; Toledo, M.T.; Padilla, R. Olivine of dolomite as in-bed additive in biomass gasification with air in a fluidized bed: which is better? Energy \& Fuels 2004, 18, 713.

28. Courson, C.; Udron, L.; Świerczyński, D.; Petit, C.; Kiennemann A. Hydrogen production from biomass gasification on nickel catalysts. Tests for dry reforming of methane. Catal. Today 2002, 76, 75.

29. Simell, P.; Kurkela, E.; Ståhlberg, P.; Hepola, J. Catalytic hot gas cleaning of gasification gas. Catal. Today 1996, 27, 55.

30. Wang, D.; Montané, D.; Chornet, E. Catalytic steam reforming of biomass-derived oxygenates: acetic acid and hydroxyacetaldehyde. Appl. Catal. A 1996, 143, 245. 
31 Wang, D.; Czernik, S.; Montané, D.; Mann, M.; Chornet, E. Biomass to Hydrogen via Fast Pyrolysis and Catalytic Steam Reforming of the Pyrolysis Oil or Its Fractions. Ind. Eng. Chem. Res. 1997, 36, 1507.

32. Marquevich, M.; Czernik, S.; Chornet, E.; Montané, D. Hydrogen from biomass: Steam Reforming of Model Compounds of Fast-Pyrolysis Oil. Energy \& Fuels 1999, 13, 1160.

33. Wang, D.; Czernik, S.; Chornet, E. Production of Hydrogen from Biomass by Catalytic Steam Reforming of Fast Pyrolysis Oils. Energy \& Fuels 1998, 12, 19.

34. Czernik, S.; French, R.; Feik, C.; Chornet, E. Hydrogen by Catalytic Steam Reforming of Liquid Byproducts from Biomass Thermoconversion Processes. Ind. Eng. Chem. Res. 2002, 41, 4209 .

35. Czernik, S.; French, R.; Feik, C.; Chornet, E. Production of Hydrogen from BiomassDerived Liquids. Proceedings of the 2000 U.S. DOE Hydrogen Program Review, San Ramon, California, U.S.A., May 9-11, 2000; NREL/CP-570-28890.

36. Magrini-Bair, K.; Czernik, S.; French, R.; Parent, Y.; Ritland, M.; Chornet, E. Fluidizable catalysts for producing hydrogen by steam reforming biomass pyrolysis liquids. Proceedings of the 2002 U.S. DOE Hydrogen Program Review, Golden, Colorado, U.S.A., May 6-10, 2002; NREL/CP-610-32405.

37. Evans, R. J.; Czernik, S.; French, R.; Magrini, K. Distributed Bio-Oil reforming; IV.A.13, DOE Hydrogen Program FY 2005 Progress Report, 2005.

38. Evans, R. J.; Czernik, S.; French, R.; Marda, J. Distributed bio-oil reforming. Proceedings of the DOE Hydrogen, Fuel Cells \& Infrastructure Technologies Program Review, Arlington, Virginia, May 16, 2006; ID\#PD5.

39. Czernik, S.; Evans, R.; French R. Hydrogen from biomass-production by steam reforming of biomass pyrolysis oil. Catal. Today 2008, 129, 265.

40. Rostrup-Nielsen, J.R.; Sehested, J.; Nørskov, J.K. Hydrogen and synthesis gas by steamand $\mathrm{CO}_{2}$ reforming. Adv. Catal. 2002, 47, 66 . 


\section{Introduction}

41. Hiller, H. et al. Ullmann: Gas Production, Wiley-VCH Verslag GmbH \& Co. KGaA, Weinheim, Germany, 2007.

42. Takanabe, K.; Aika, K.; Seshan, K.; Lefferts, L. Sustainable hydrogen from bio-oil Steam reforming of acetic acid as a model oxygenate. J. Catal. 2004, 227, 101.

43. Basagiannis, A.C.; Verykios, X.E. Catalytic steam reforming of acetic acid for hydrogen production. Int. J. Hydrogen Energy 2007, 32, 3343.

44. Bimbela, F.; Oliva, M.; Ruiz, J.; García, L.; Arauzo, J. Hydrogen production by catalytic steam reforming of acetic acid, a model compound of biomass pyrolysis liquids. J. Anal. Appl. Pyrolysis 2007, 79, 112.

45. Davidian, T.; Guilhaume, N.; Iojoiu, E.; Provendier, H.; Mirodatos, C. Hydrogen production from crude pyrolysis oil by a sequential catalytic process. Appl. Catal. B 2007, 73, 116.

46. Davidian, T.; Guilhaume, N.; Provendier, H.; Mirodatos, C. Continuous hydrogen production by sequential catalytic cracking of acetic acid Part II. Mechanistic features and characterization of catalysts under redox cycling. Appl. Catal. A 2008, 337, 111.

47. Iojoiu, E.E.; Domine, M.E.; Davidian, T.; Guilhaume, N.; Mirodatos, C. Hydrogen production by sequential cracking of biomass-derived pyrolysis oil over noble metal catalysts supported on ceria-zirconia. Appl. Catal. A 2007, 323, 147.

48. Polychronopoulou, K. Efstathiou, A.M. Spillover of labile OH, H, and O species in the $\mathrm{H}_{2}$ production by steam reforming of phenol over supported-Rh catalysts. Catal. Today 2006, 116, 341 .

49. Kechagiopoulos, P.N.; Voutetakis, S.S.; Lemonidou, A.A.; Vasalos, I.A. Sustainable hydrogen production via reforming of ethylene glycol using a novel spouted bed reactor. Catal. Today 2007, 127, 246. 
50. Matas Güell, B.; Torres da Silva, I.M.; Seshan, K.; Lefferts, L. Sustainable route to hydrogen - Design of stable catalysts for the steam gasification of biomass related oxygenates. Appl. Catal. B 2009, 1-2, 38.

51. Rennard, D.C.; Dauenhauer, P.J.; Tupy, S.A.; Schmidt, L.D. Autothermal Catalytic Partial Oxidation of Bio-Oil Functional Groups: Esters and Acids. Energy \& Fuels 2008, 22,1318 .

52. Takanabe, K.; Aika, K.; Inazu, K.; Baba, T.; Seshan, K.; Lefferts, L. Steam reforming of acetic acid as a biomass derived oxygenate: Bifunctional pathway for hydrogen formation over Pt/ZrO 2 catalysts. J. Catal. 2006, 243, 263.

53 Wang, Z.; Pan, Y.; Dong, T.; Zhu, X.; Kan, T.; Yuan, L.; Torimoto, Y.; Sadakata, M.; Li, Q. Production of hydrogen from catalytic steam reforming of bio-oil using C12A7-O based catalysts. Appl. Catal. A 2007, 320, 24.

54. Galdámez, J.R.; García, L.; Bilbao, R. Hydrogen Production by Steam Reforming of BioOil Using Coprecipitated Ni-Al Catalysts. Acetic Acid as a Model Compound. Energy \& Fuels 2005, 19, 1133.

55. Ramos, M.C.; Navascues, A.I.; García, L.; Bilbao, R. Hydrogen Production by Catalytic Steam Reforming of Acetol, a Model Compound of Bio-Oil. Ind. Eng. Chem. Res. 2007, 46, 2399.

56. Rioche, C.; Kulkarni, S.; Meunier, F.C.; Breen, J.P.; Burch, R. Steam reforming of model compounds and fast pyrolysis bio-oil on supported noble metal catalysts. Appl. Catal. B $2005,61,130$.

57. Matas Güell, B. Ph.D. Thesis, University of Twente, Thesis defense $9^{\text {th }}$ of October 2009.

58. Magrini-Bair, K.A.; Czernik, S.; French, R.; Parent, Y.O.; Chornet, E.; Dayton, D.C.; Feik, C.; Bain, R. Fluidizable reforming catalyst development for conditioning biomassderived syngas. Appl. Catal. A 2007, 318, 199. 


\section{Introduction}

59. Courson, C.; Makaga, E.; Petit, C.; Kiennemann, A. Development of Ni catalysts for gas production from biomass gasification. Reactivity in steam- and dry-reforming. Catal. Today 2000, 63, 427.

60. Courson, C.; Udron, L.; Świerczyński, D.; Petit, C.; Kiennemann, A. Hydrogen production from biomass gasification on nickel catalysts. Tests for dry reforming of methane. Catal. Today 2002, 76, 75.

61. Pfeifer, C.; Rauch, R.; Hofbauer, H.. Hydrogen-rich gas production with a Ni-catalyst in a dual fluidized bed biomass gasifier. Science in Thermal and Chemical Biomass Conversion. Volume 1, ed. Bridgwater, A.V.; Boocock, D.G.B. CPL Press, UK, 2006, 677.

62. Felix, L.; Choi, C.; Rue, D.; Slimane, R.; West, L.; Seward, T. Glass-ceramic catalysts for tar decomposition and GTL synthesis in biomass gasification. Proceedings of the $16^{\text {th }}$ European Biomass Conference, Valencia, Spain, June 2-6, 2008, 1067. 


\title{
Chapter 2
}

\section{Catalytic and Noncatalytic Gasification of Pyrolysis Oil}

\begin{abstract}
Gasification of pyrolysis oil was studied in a fluidized bed over a wide temperature range (523-914 $\left.{ }^{\circ} \mathrm{C}\right)$ with and without the use of nickel-based catalysts. Noncatalytically, a typical fuel gas was produced. Both a special designed fluid bed catalyst and a crushed commercial fixed bed catalyst showed an initial activity for syngas ( $\mathrm{H}_{2}$ and $\mathrm{CO}$ ) production at $T>700{ }^{\circ} \mathrm{C}$. However, these catalysts lost activity irreversibly and elutriation from the fluid bed occurred. The equilibrium catalytic activity suffered from incomplete reforming of hydrocarbons $\left(\mathrm{CH}_{4}\right)$. In all the experiments the carbon to gas conversion was incomplete, which was mainly caused by the formation of deposits and the slip of microcarbonaceous particles. A two stage reactor concept, which consisted of a sand fluidized bed followed by a fixed catalytic bed, was proposed and tested. This system uncouples the atomization/cracking of the oil and the catalytic conditioning of the produced gases, enabling protection of the catalyst and creating opportunities for energy efficiency improvements. In a bench scale unit of this reactor $(0.5 \mathrm{~kg}$ oil/h), methane and $\mathrm{C}_{2}-\mathrm{C}_{3}$ free syngas $\left(2.1 \mathrm{Nm}^{3} \mathrm{CO}+\mathrm{H}_{2} / \mathrm{kg}\right.$ dry oil, $\left.\mathrm{H}_{2} / \mathrm{CO}=2.6\right)$ with a low tar content $\left(0.2 \mathrm{~g} / \mathrm{Nm}^{3} ; \mathrm{dry}, \mathrm{N}_{2}\right.$ free gas) was produced in a long duration test (11 h).
\end{abstract}

Adapted from:

Van Rossum, G.; Kersten, S.R.A.; Van Swaaij, W.P.M. Ind. Eng. Chem. Res. 2007, 45, 3959. 


\subsection{Introduction}

Increasing environmental concerns about excessive net carbon dioxide emissions, the steadily decrease of easily accessible fossil fuels, and the rising demand for a secure supply of fuel, chemicals, and energy have increased the interest in renewable and sustainable sources.

Additional biomass utilization will be indispensable when looking at future renewable scenarios. This is because it has some properties which cannot be fulfilled or will be hard to fulfill by the other sustainable sources: solar, hydro, wind, and geothermal.

- Biomass contains carbon, hydrogen, and oxygen atoms, and in this way, it is a suitable sustainable source for the production of conventional and new chemicals and fuels.

- Additional biomass utilization can be integrated in already existing biomass production cycles, besides specific biomass crop production on designated land.

- Biomass, or processed products, can be easily stored compared to other sources.

In this Thesis, the production of biobased syngas via catalytic gasification of pyrolysis oil is discussed.

Pyrolysis oil, also called bio-oil, is produced from relatively dry biomass. In the fast pyrolysis process, biomass is quickly heated to $400-600{ }^{\circ} \mathrm{C}$ in the absence of oxygen. The long biomass molecules are destroyed yielding permanent gases, vapors, and char. By condensation of the vapors, a liquid is obtained containing mainly a variety of oxygenated hydrocarbons and water. By choosing the proper process conditions, up to $70 \mathrm{wt} \%$ of the original biomass can be captured in the pyrolysis oil [1].

During the 1980s and 1990s, extensive research was initiated on fast pyrolysis technology. This has resulted in demonstration plants, based on various reactor types, and the first small production plants. Recent developments are going toward actual large scale production. Up till now, pyrolysis oil has mainly been tested for heat and power production or coproduction [2]. However, pyrolysis oils have a few distinct advantages over their original biomass sources, which make them interesting for added value applications.

- First, the volumetric energy density is increased by roughly five times compared to 'bulk' biomass. This makes transport, especially over long distances, 
economically more attractive. When large scale biomass utilization is considered, pyrolysis oil can be produced locally from where it is transported to central processing units, thus decoupling the biomass availability and demand.

- Second, from bulky biomass solids, a liquid is created. This makes storage, transport, processing, and pressurization more effective.

- Third, pyrolysis oil is cleaner than the original feedstock. Because of the relative low process temperature, the minerals and metals remain in the solid state and are concentrated in the char. In this way, an option is created to recycle the metals and minerals locally to the soil. Additionally, catalytic upgrading of pyrolysis oil to high value fuels and chemicals becomes within reach since most of the impurities which deactivate catalysts are separated in the fast pyrolysis process.

Synthesis gas (syngas) is a very important intermediate product for many processes with a production of $6 \mathrm{TJ}$ per year in 2003 [3], which is roughly $2 \%$ of the world's energy consumption. It is essentially hydrogen and carbon monoxide and can be produced in various ways and grades via gasification. It is mainly used for the production of ammonia, hydrogen, methanol, oxo-chemicals, Fischer-Tropsch fuels, heat, and power.

Syngas is produced by reacting a fuel (coal, naphtha, oil/tar, natural gas, and biomass) with steam and/or oxygen at elevated temperatures and usually also elevated pressures. The essential reactions of gasification are pyrolysis, oxidation, carbon gasification, reforming (steam and/or dry), cracking, and water gas shift to yield synthesis gas, water, carbon dioxide, and unwanted products like tars, methane and carbon [4].

$\mathrm{C}_{x} \mathrm{H}_{y} \mathrm{O}_{z}+a \mathrm{H}_{2} \mathrm{O} / \mathrm{O}_{2} \rightarrow \mathrm{H}_{2}+\mathrm{CO}+\mathrm{CO}_{2}+\mathrm{CH}_{4}+\mathrm{C}_{2+}+\operatorname{Tars}+\mathrm{C}_{(s)}$

At very high temperatures $\left(>1250^{\circ} \mathrm{C}\right)$, all reactions occur at such a high speed that thermodynamic equilibrium of the gases is reached without the use of a catalyst using entrained flow technology. Modern coal and oil gasifiers are operated in this temperature regime yielding a tar and methane free synthesis gas $\left(\mathrm{H}_{2}, \mathrm{CO}, \mathrm{CO}_{2}\right.$, and $\left.\mathrm{H}_{2} \mathrm{O}\right)$, at the expense of relative high energy usage and equipment cost [5].

At lower temperatures $\left(<1000{ }^{\circ} \mathrm{C}\right)$ and without a catalyst, fuel gas $\left(\mathrm{H}_{2}, \mathrm{CO}, \mathrm{CO}_{2}\right.$, $\mathrm{H}_{2} \mathrm{O}, \mathrm{CH}_{4}, \mathrm{C}_{2+}$, tars, and, in the case of air blown gasification, $\mathrm{N}_{2}$ ) is obtained, which has to be upgraded before usage as pure syngas. For combustion, the purification demands 
are less severe. Coal and biomass gasifiers are being operated in this lower temperature regime using fluid or fixed bed technology, sometimes in combination with 'simple' mineral and clay catalysts to improve the gas quality or reduce downstream cleaning requirements. To allow the application of sensitive and dedicated catalysis, the fuel source needs to be clean. Biomass, coal, and many heavy oils/tars are as such not suitable. Minerals, metals, and sulfur tend to deactivate dedicated catalysts, and therefore, direct contact with these pollutants should be minimized. Ash produced from the minerals and metals sets boundaries to the temperature of operation. Ash should be either in a totally molten or solid state, not in between. This creates a 'forbidden' temperature zone, depending on the ash composition $\left(1050-1250{ }^{\circ} \mathrm{C}\right)$, where ash containing fuels cannot be effectively converted.

Clean ash free fuels, like natural gas and naphtha, have been successfully converted using nickel-based catalysts via steam, auto-, and pre-reforming [6]. To keep a proper catalyst activity, sufficient steam should be present $(\mathrm{S} / \mathrm{C} \sim 3)$, sulfur levels should be low and temperature peaks should be avoided.

Pyrolysis oils can potentially be gasified in all aforementioned conversion routes, and possibly even in the $1000-1250^{\circ} \mathrm{C}$ zone due to the low ash content.

High-temperature $\left(>1200{ }^{\circ} \mathrm{C}\right)$ entrained flow gasification of pyrolysis oil was proposed and tested by Henrich et al. [7] yielding a clean synthesis gas $\left(\mathrm{CH}_{4}<0.5 \mathrm{vol} \%\right)$ and full carbon conversion. To compensate for the fact that pyrolysis oil itself has a relatively low heating value (LHV $\sim 17 \mathrm{MJ} / \mathrm{kg}$ ) [8] compared to fossil fuels, char produced in the pyrolysis step was suspended in the pyrolysis oil to create a slurry.

Low temperature fixed bed pyrolysis oil gasification $\left(\leq 800^{\circ} \mathrm{C}\right)$ in a microreactor has been investigated by Panigrahi et al. [9]. Carbon to gas conversions up to $84 \%$ were attained, creating a methane and $\mathrm{C}_{2+}$ rich fuel gas.

Catalytic conversion of the aqueous phase of pyrolysis oil has been extensively investigated by Czernik et al. [10] at NREL and recently also by Kechagiopoulos et al. [11] using nickel-based steam reforming catalysts. High carbon to gas conversions (95\%) and hydrogen yields $(80 \%)$ were attained at $850{ }^{\circ} \mathrm{C}$; a methane free gas could however not be produced, and unrealistically high $\mathrm{S} / \mathrm{C}$ ratios $(>6)$ were used. Catalyst development for the conversion of pyrolysis oil by various groups is making progress and can be divided in two types of efforts. First, activity improvements and understanding reaction 
mechanisms is the main aim in experiments using model compounds which are present in the pyrolysis oil like acetic acid, alcohols, and phenol [12-19]. A second type of development is directed to improve the mechanical strength for resisting attrition and sintering for catalytic usage in fluidized beds [20,21].

The application of a fluidized bed has been proposed $[10,11]$ and is often preferred especially in a twin bed setup for integration/coupling of endothermic reactions (cracking, reforming) and exothermic reactions (e.g. coke burning). In the case of pyrolysis oils, there is another important reason for the application of a fluid bed system. Pyrolysis oil (or its fractions) cannot be totally re-evaporated and needs to be kept at low temperatures $\left(<80{ }^{\circ} \mathrm{C}\right)$ until the point of entering the reactor to avoid charring of the oil. Carbon deposits will inevitably be formed in a reactor which will clog a fixed bed while it is envisaged that in a fluidized bed carbon deposits are distributed over the whole bed. Besides this carbon deposition problem, the energy which is needed for combined evaporation, heating, and steam reforming of pyrolysis oil is very high [22]. When using a fixed bed reactor, this high heat demand has to be locally supplied at the entrance of the reactor. For medium or large scale fixed bed reformer reactors, this supply of energy will present a problem, lowering the local temperature. For possible future commercial systems, this energy requirement needs to be extensively investigated. The evaporation of pyrolysis oil and reforming to syngas could possibly take place in separate zones. Moreover, lowering the temperature of re-evaporation could be interesting since from an exergy point of view, injecting a cold water-rich pyrolysis oil directly into a hot $\left(>700{ }^{\circ} \mathrm{C}\right)$ environment is not preferred. Efforts in this direction have been initiated by Czernik et al. [23] using methanol stabilized pyrolysis oil.

To pave the way to an economically viable low-temperature pyrolysis oil to syngas process, our present research is focused on the following:

- Investigation of fluidized bed pyrolysis oil gasification over a wide temperature range $\left(523-914{ }^{\circ} \mathrm{C}\right)$ using the whole oil.

- Influence of catalyst addition on gas production and composition.

- Identification of important aspects for reactor and process design of pyrolysis oil gasification. 


\subsection{Experimental}

\subsubsection{Materials}

The pyrolysis oils used were produced in the pilot plant facility $(200 \mathrm{~kg} / \mathrm{h})$ of the company BTG, The Netherlands. The pyrolysis oils were produced from beech or pine wood chips and were filtered over a $10 \mu \mathrm{m}$ filter before usage. The CHNS elemental analyses and Karl Fischer water determinations for all the feedstocks are given in

Table 2.1.

Table 2.1. Elemental analyses and water content determinations of the pyrolysis oils used. ${ }^{a}$

\begin{tabular}{c|cc}
\hline (wt\%) & Beech wood pyrolysis oil & Pine wood pyrolysis oil \\
\hline $\mathbf{C}$ & $30.4-37.7$ & $38.1-39.9$ \\
$\mathbf{H}$ & $7.6-7.9$ & $7.9-8.3$ \\
$\mathbf{O}$ & $54.4-61.7$ & $51.6-53.7$ \\
$\mathbf{N}$ & $<0.01-0.27$ & $0.13-0.16$ \\
$\mathbf{S}$ & $<0.01$ & $<0.01$ \\
$\mathbf{H}_{2} \mathbf{O}$ & $32.5-43.7$ & $29.7-30.4$ \\
& &
\end{tabular}

As can be seen from the indicated range of analysis in Table 2.1 (beech wood pyrolysis oil), the composition can vary. This composition variation is ascribed to the following:

- Different batches of pyrolysis oils were used. These batches were produced at slightly different process conditions.

- Pyrolysis oil can gradually age in time.

- Error in the analysis technique.

Although the water content of the used pyrolysis oils was high, this type of pyrolysis oil also contains, besides water soluble compounds, water insoluble compounds as reported by Branca [27] and Oasmaa [28]. 
Three different types of nickel-alumina catalysts were used in this research, all provided by Johnson Matthey. The catalyst (FB) most used in this research was a specially designed $\mathrm{Ni}-\mathrm{K} / \mathrm{La}$ on alumina fluidizable catalyst $(200-300 \mu \mathrm{m})$, developed within an EU project (Bio-electricity; ENK5 CT2002-00634). The other two were commercial fixed bed KATALCO catalysts: 23 (K23; methane reforming) and 46 (K46; naphtha reforming). Besides using the catalysts as received, KATALCO 46 was also grounded to smaller particles $(200-300 \mu \mathrm{m})$ prior to application in a fluidized bed.

\subsubsection{Setup}

A schematic overview of the setup is given in Figure 2.1. All equipment, that was heated, was made of stainless steel (SS310S). The reactor was operated near atmospheric pressure $(<0.1$ barg). The reactor consisted of a cylinder (diameter $108 \mathrm{~mm}$, height $\sim 72 \mathrm{~cm}$ ), which was filled with 4-9 $\mathrm{kg}$ of either sand $(150-450 \mu \mathrm{m})$, catalyst, or a mixture of the two. The lower part of the reactor was conical in shape in the center of which the gases $\left(\mathrm{H}_{2}, \mathrm{~N}_{2}\right.$, air, and $\left.\mathrm{CO}_{2}\right)$, steam and pyrolysis oil $(0.2-2.5 \mathrm{~kg} / \mathrm{h})$, were added in an upward flow. The conical design created spouting behavior in the lower part of the reactor, which made the presence of a distribution plate not necessary, and therefore, the pyrolysis oil could be directly atomized in the axial direction. A freeboard (diameter $196 \mathrm{~mm}$, height $\sim 33 \mathrm{~cm}$ ) was placed on top of the reactor to avoid excessive loss of bed material during operation. The superficial gas velocities at the top of the fluid bed were between 10 and $30 \mathrm{~cm} / \mathrm{s}$ corresponding to contact times between 0.5 and $4 \mathrm{~s}$. 
Catalytic and Noncatalytic Gasification of Pyrolysis Oil

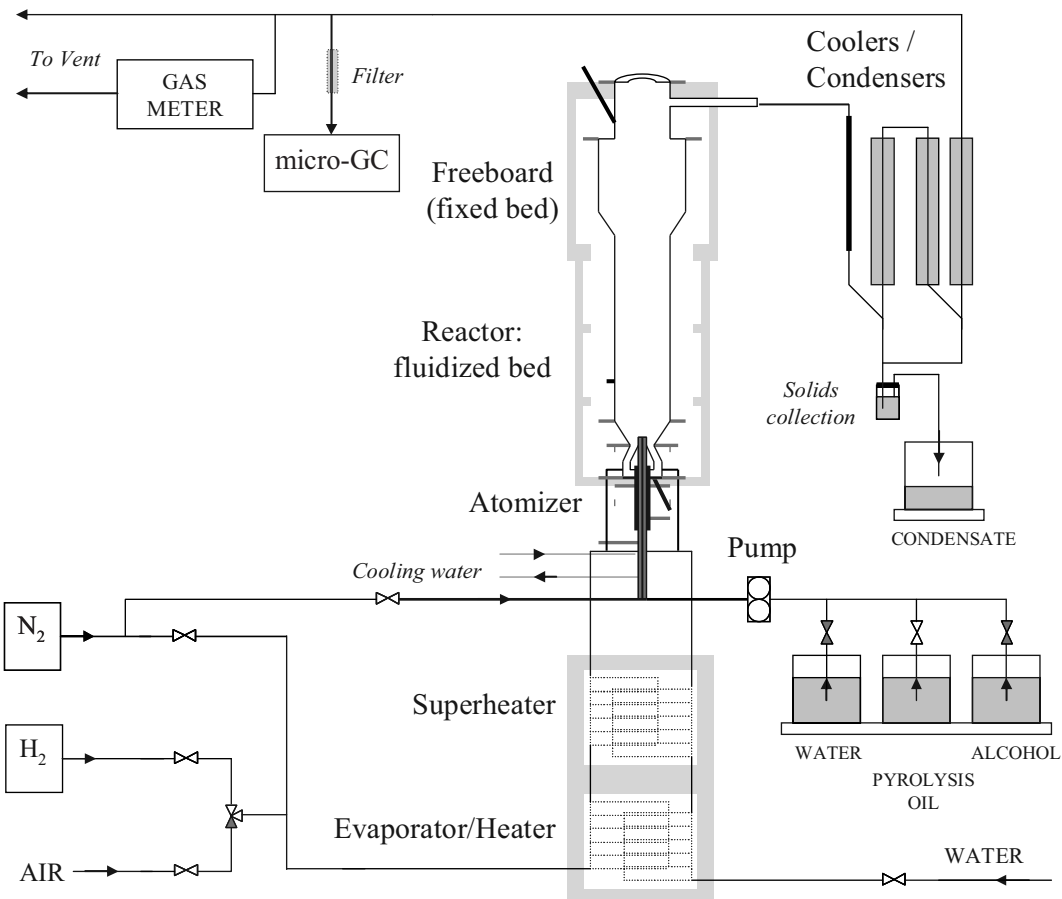

Figure 2.1. Schematic overview of the fluidized bed setup.

In one experiment, a fixed catalyst bed was placed inside the freeboard. This bed consisted of first $2.5 \mathrm{~kg}$ of KATALCO 46-3Q followed by $5.1 \mathrm{~kg}$ of KATALCO 23-4Q.

The pyrolysis oil was atomized prior to contacting it with the hot fluid bed material using an internally mixed gas-assisted atomizer using nitrogen as the atomizing gas. The pyrolysis oil was cooled $\left(<80{ }^{\circ} \mathrm{C}\right)$ up to the tip of the atomizer to avoid its thermal decomposition. Additional gases and steam for fluidization of the bed material were heated $\left(500-950{ }^{\circ} \mathrm{C}\right)$ before addition. At the reactor exit, the gas was cooled to $20-35{ }^{\circ} \mathrm{C}$ using a gas cooler, a water cooler, and two consecutive deep cooled water coolers to condense out most of the water. The collected water contained some particles, which were separated. A micro-GC (Varian CP-4900; 10 m molsieve 5A Ar, 10 m molsieve 5A $\mathrm{He}, 10 \mathrm{~m}$ PPQ He, $8 \mathrm{~m}$ Sil-5CB He) was used for detecting $\mathrm{H}_{2}, \mathrm{O}_{2}, \mathrm{~N}_{2}, \mathrm{CH}_{4}, \mathrm{CO}, \mathrm{CO}_{2}$, $\mathrm{C}_{2} \mathrm{H}_{4}, \mathrm{C}_{2} \mathrm{H}_{6}, \mathrm{C}_{3} \mathrm{H}_{6}$, and $\mathrm{C}_{3} \mathrm{H}_{8}$ every $4.1 \mathrm{~min}$. For some experiments, a different $\mathrm{GC}$ was used (Shimadzu GC-14B; molsieve He, 2x poraplot He). In a few experiments, solid phase absorption (SPA) samples were taken of the gas at the reactor outlet $\left(\sim 450{ }^{\circ} \mathrm{C}\right)$ and 
analyzed to determine the tar content and type over a wide range (benzene to coronene). The known amount of nitrogen, added to the system, was used as an internal standard to calculate gas productions. The product gas composition did not fluctuate much in time during continuous operation at fixed gasification conditions (see Figures 2.2 and 2.3).

All the gas flows and the water flow (for steam production) were controlled by digital mass flow controllers (Brooks Instruments). The pyrolysis oil flow was controlled by a displacement pump. Temperature and pressure measurements were taken at various points of the setup/reactor for controlling and measuring purposes. The pyrolysis oil and condensate vessels were weighted during the experiment for calculating the actual flow rates.

The setup was heated to the desired temperature under an $\mathrm{N}_{2} / \mathrm{H}_{2} \mathrm{O}$ /air atmosphere when using sand as a bed material. An $\mathrm{N}_{2} / \mathrm{H}_{2}$ atmosphere (from $500{ }^{\circ} \mathrm{C}$ for at least $2 \mathrm{~h}$ ) was used if a catalyst was applied as bed material to allow activation of the catalyst via reduction. To keep the atomizer at a desired temperature $\left(<80^{\circ} \mathrm{C}\right)$, on top of external cooling, a small amount of water was atomized during the startup. Prior to the start and at the end of an experiment, the atomizer was flushed with alcohol (30-60 s) to clean the lining toward the atomizer and to avoid phase separation of the pyrolysis oil when it would come in contact with water, which could lead to clogging of the atomizer. After the experiment, steam and/or air were used to remove carbonaceous deposits which were formed inside the reactor during the experiment.

\subsubsection{Definitions}

In the results presented, the carbon to gas conversion is defined as the percentage of carbon from the feed converted to the following gaseous products: $\mathrm{CH}_{4}, \mathrm{CO}, \mathrm{CO}_{2}, \mathrm{C}_{2} \mathrm{H}_{4}$, $\mathrm{C}_{2} \mathrm{H}_{6}, \mathrm{C}_{3} \mathrm{H}_{6}$, and $\mathrm{C}_{3} \mathrm{H}_{8}$. The gas productions are defined as normal cubic meters (at $0{ }^{\circ} \mathrm{C}$ and $1 \mathrm{~atm})$ per kilogram of dry feed. The hydrogen yield is defined as the percentage of the maximum amount of hydrogen, which can be produced according to the following reaction:

$\mathrm{C}_{x} \mathrm{H}_{y} \mathrm{O}_{z}+(2 x-z) \mathrm{H}_{2} \mathrm{O} \rightarrow x \mathrm{CO}_{2}+\left(\frac{y}{2}+2 x-z\right) \mathrm{H}_{2}$ 
The carbon to gas conversion, gas production, and hydrogen yield are calculated from steady-state operation, excluding startup and initial deactivation profiles of the catalysts. The equivalence ratio $(\lambda)$ is defined as the percentage of oxygen added for total combustion of the feedstock according to the following:

$\mathrm{C}_{x} \mathrm{H}_{y} \mathrm{O}_{z}+\left(x+\frac{y}{4}-\frac{z}{2}\right) \mathrm{O}_{2} \rightarrow x \mathrm{CO}_{2}+\frac{y}{2} \mathrm{H}_{2} \mathrm{O}$

The steam over carbon ratio $(\mathrm{S} / \mathrm{C})$ is defined as the ratio of the total amount of moles of steam, including the water content of the feedstock, over the moles of carbon in the feedstock.

The secondary and tertiary tar contents, from SPA analyzes, are presented in grams per kilogram of dry pyrolysis oil $(\mathrm{g} / \mathrm{kg})$ and in grams per normal cubic meter of dry and nitrogen free gas $\left(\mathrm{g} / \mathrm{Nm}^{3}\right)$.

Since this Chapter focuses on developing a process to create a clean syngas using various reactions, reactants, and reactor combinations, the overall term of 'gasification' is used. It includes the following reactions: cracking, oxidation, steam/dry reforming, and water gas shift. When a catalyst is applied, the term 'catalytic gasification' is used.

\section{$2.3 \quad$ Results}

\subsubsection{Fluidized Bed}

In the case that no catalyst was used during the gasification tests, the condensate had a yellow/orange color; at very low temperatures, even a tarlike substance was separated from the condensate. When a catalyst was used, the condensate had only a faint light yellowish color; at higher temperature experiments, the condensate appeared clear. During a typical experiment, a small amount $(<0.2 \mathrm{wt} \%)$ of bed material was elutriated from the reactor when using sand due to the violent bubbling behavior of the fluidized bed; the bed material loss when using a catalyst was somewhat higher. Together with the elutriated bed material, also small amounts of very fine carbonaceous particles came with the gas flow. Attempts to keep these fine particles in the reactor by an internal cyclone 
were unsuccessful. The origin, composition, and formation of these small carbonaceous particles are investigated in Chapter 4.

\subsubsection{Inert Fluidized Bed Gasification}

A representative experimental run of noncatalytic pyrolysis oil gasification using a fluidized bed is shown in Figure 2.2 (see also Table 2.2, column 1). The gas production and composition were constant in time. A typical fuel gas is obtained where the gas is rich in carbon monoxide and methane while having low carbon dioxide and hydrogen concentrations. $\mathrm{C}_{2}-\mathrm{C}_{3}$ and methane components, which can be considered as an indication of tar content, are available in high amounts. SPA analyzes results in a tar content of $\sim 2.2 \mathrm{~g} / \mathrm{kg}\left(2.6 \mathrm{~g} / \mathrm{Nm}^{3}\right)$, which is less than that typically obtained during biomass gasification under similar conditions (17 g/kg dry biomass) [24].

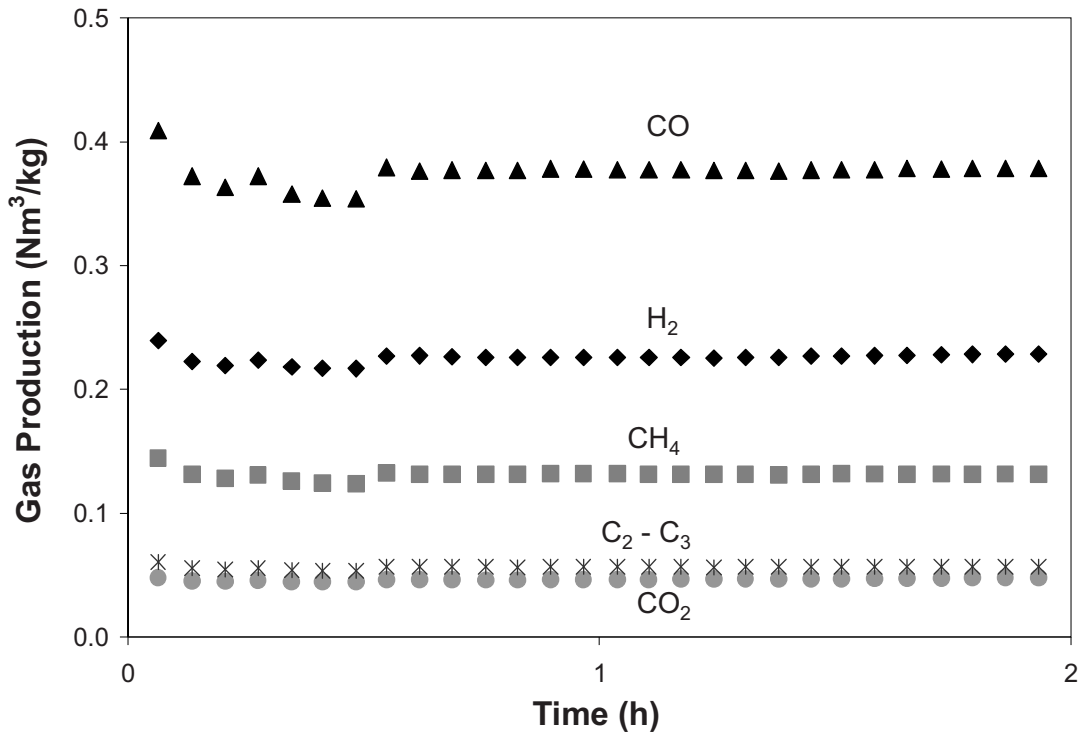

Figure 2.2. Gas production of noncatalytic pyrolysis oil gasification versus time: total pyrolysis oil flow $=0.64 \mathrm{~kg} / \mathrm{h}$ (pine, wet basis), temperature $=790^{\circ} \mathrm{C}, \mathrm{S} / \mathrm{C}$ ratio $=1.9$, nitrogen flow $=10 \mathrm{~nL} / \mathrm{min}$, sand fluidized bed loading $=5.1 \mathrm{~kg}$, hydrogen yield $=10 \%$, carbon to gas conversion $=65 \%$, equivalence ratio $=0 \%$. 


\subsubsection{Catalytic Fluidized Bed Gasification}

Figure 2.3 shows three consecutive runs, which were done with the same catalyst (FB). In the first run, the catalyst was activated in a hydrogen atmosphere and further used as received. When the pyrolysis oil flow was stopped, steam was first used to partly gasify carbonaceous deposits and oxidize the catalyst. When the hydrogen and carbon dioxide concentrations were low, a diluted air/steam mixture (oxygen $\sim 1.5 \mathrm{vol} \%$ ) was used to completely oxidize/gasify the remaining carbonaceous deposits. In this way temperature peaks, which could damage the catalyst, were avoided. This activation/burnoff cycle was then repeated for the following runs. When using the catalyst for the first time, a hydrogen concentration of $62.7 \mathrm{vol} \%$ was attained $\left(\mathrm{CO}=14.3, \mathrm{CH}_{4}=1.9, \mathrm{CO}_{2}=20.9\right.$, and $\left.\mathrm{C}_{2}-\mathrm{C}_{3}=0.2\right)$. However, after about $10 \mathrm{~min}$, the catalyst started to lose its initial high reforming activity while methane and $\mathrm{C}_{2}-\mathrm{C}_{3}$ production increased at the cost of mainly hydrogen and carbon monoxide production. After roughly $1 \mathrm{~h}$, the activity loss started to stabilize $\left(\mathrm{H}_{2}=54.5 \%, \mathrm{CO}=11.0 \%\right.$, $\mathrm{CH}_{4}=7.5 \%, \mathrm{CO}_{2}=23.7 \%$, and $\mathrm{C}_{2}-\mathrm{C}_{3}=1.1 \%$ ) with a tar content of roughly $\sim 2.4 \mathrm{~g} / \mathrm{kg}$ $\left(1.4 \mathrm{~g} / \mathrm{Nm}^{3}\right)$. During the initial activity loss, the hydrogen yield dropped from $64 \%$ to 47\%. Similar behavior, but to a lesser extent, is described by Czernik et al. [21] for steam reforming of the aqueous fraction of pyrolysis oil. What is noticeable to mention, is that the carbon to gas conversion remained constant over the whole run and therefore seemed to be unaffected by this activity loss. When the catalyst was reactivated for the second run, it did not recover its initial high activity but instead lost some more activity. After additional burnoff reactivation cycles, this 'equilibrium' activity was maintained. The carbon to gas conversion remained constant over the additional cycles at constant process conditions. Around $4 \%$ of the carbon was trapped in the bed and was recovered during the burnoff mainly as carbon dioxide. 


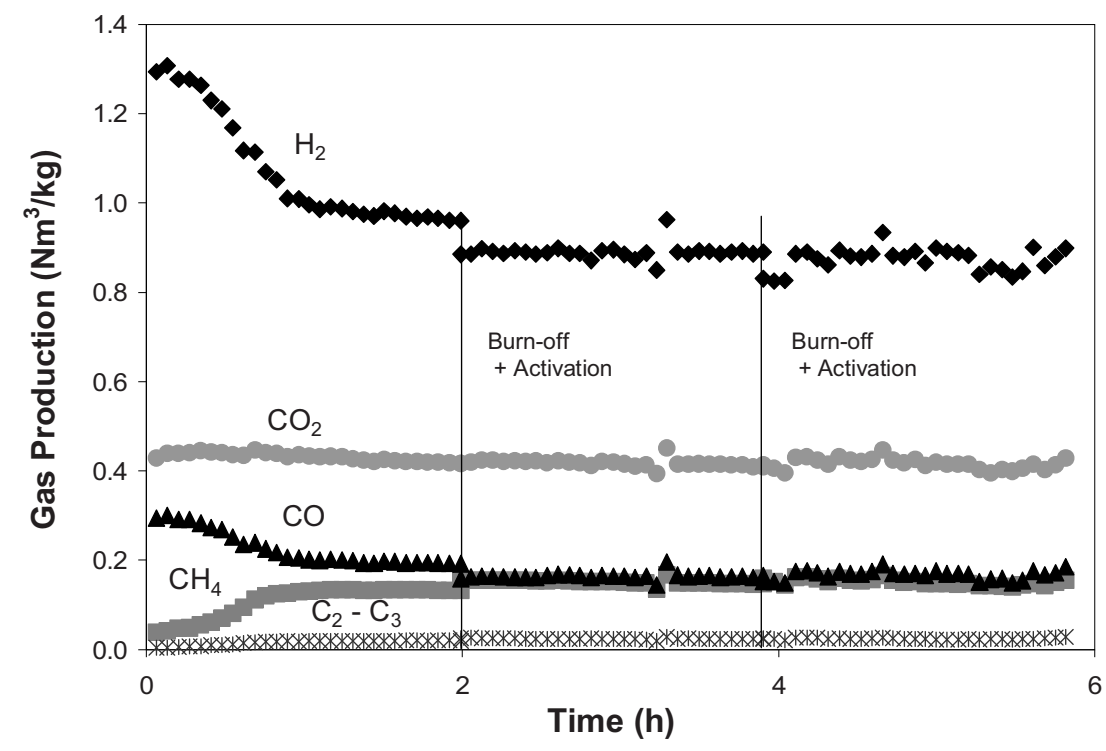

Figure 2.3. Gas production of catalytic (FB) pyrolysis oil gasification versus time. Three consecutive runs where burnoff and hydrogen reactivation took place were conducted between the experiments: total pyrolysis oil flow $=0.45,0.48,0.52 \mathrm{~kg} / \mathrm{h}$ (beech, wet basis); temperature $=816,815,816^{\circ} \mathrm{C} ; \mathrm{S} / \mathrm{C}$ ratio $=3.2,3.3,3.1 ;$ nitrogen flow $=10 \mathrm{~nL} / \mathrm{min}$; catalyst fluidized bed loading $=4.5 \mathrm{~kg}$; hydrogen yield $=52,44,43 \%$; carbon to gas conversion $=79,77,78 \%$; equivalence ratio $=0 \%$.

Scanning electron microscope (SEM) photographs, taken of the catalyst surface at various phases of a run, are shown in Figure 2.4. A clear change of surface is observed for the catalyst before usage $(2.4 \mathrm{~A})$, a catalyst after contact with pyrolysis oil (2.4B; for conditions, see Table 2.2, column 2), and a catalyst after burnoff. The catalyst before usage has a highly structured surface while a reused catalyst shows a smoothened surface. Energy dispersive X-ray (EDX) analysis of the catalyst after contact with pyrolysis oil (2.4B) shows the presence of carbonaceous materials on the catalyst, which are distributed over the surface as very fine particulates.

The surface change of the catalyst probably has a major contribution to the initial activity loss. This activity loss cannot be contributed to carbon deposition/formation on the catalyst, because (i) the activity loss is irreversible which is not typical for activity loss due to carbon buildup and (ii) the constant 'equilibrium' activity during a run shows 
that possible cumulative carbon deposition during the time of measurement has no effect. The unaffected carbon to gas conversion during the runs shows that the activity loss is not with respect to initial pyrolysis oil conversion. This suggests that the initial pyrolysis oil conversion is thermally driven where the catalytic activity is mainly to condition the gas composition. The ability to effectively convert methane via steam reforming to hydrogen is the major activity loss being observed.

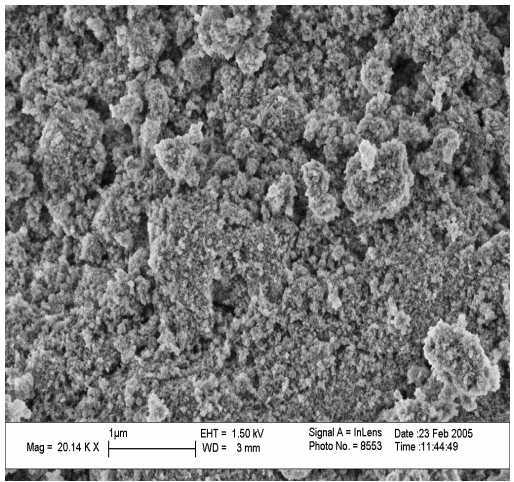

(A)

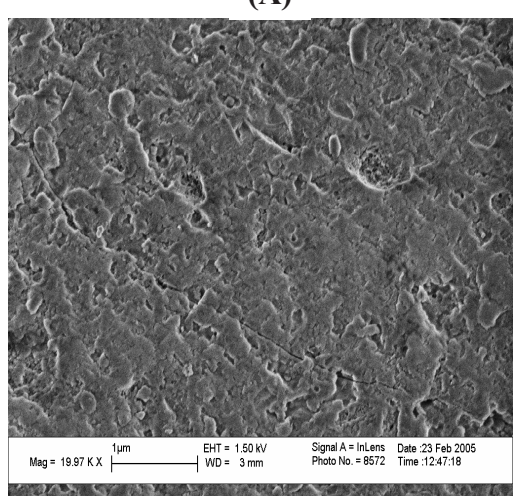

(C)

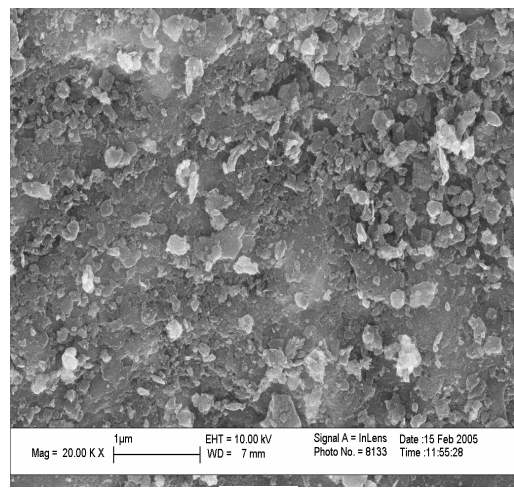

(B)

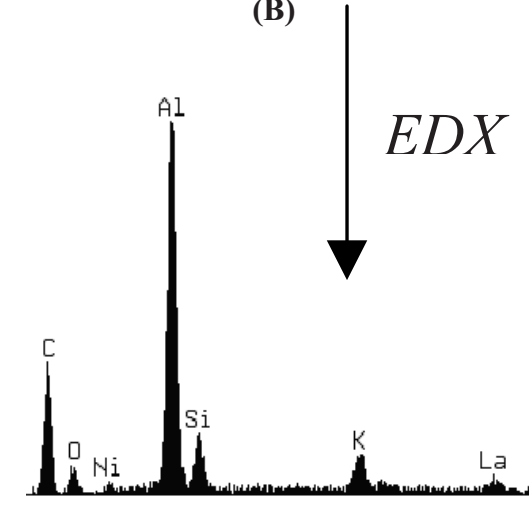

Figure 2.4. SEM photographs of catalyst (FB) surfaces: (A) fresh catalyst particle, (B) catalyst particle after reaction but before burnoff including EDX analysis, (C) catalyst particle after burnoff; magnification 20,000 x; defined scale $1 \mu \mathrm{m}$ 
2.3.4 Influence of the Temperature on Fluidized Bed Catalytic and Noncatalytic Gasification

The effect of temperature on fluidized bed steam gasification of pyrolysis oil has been studied both for the noncatalytic and the catalytic process. Figure 2.5 shows the (A) carbon to gas conversion, (B) hydrogen yield and (C) syngas, (D) methane, (E) carbon dioxide, and $(\mathrm{F}) \mathrm{C}_{2}-\mathrm{C}_{3}$ gas productions versus temperature. Catalytic (FB) results reported are solely of reused equilibrium catalysts, giving more consistency to the results. Beech and pine pyrolysis oils showed undistinguishable gasification behavior.

Hydrogen yield, syngas, and carbon dioxide gas production increase almost linearly with temperature. The carbon to gas conversion and methane gas production increase linearly in the lower temperature region $\left(529-678{ }^{\circ} \mathrm{C}\right)$, while they level off at higher temperatures $\left(720-887^{\circ} \mathrm{C}\right) \cdot \mathrm{C}_{2}-\mathrm{C}_{3}$ gas production is parabolic in shape. The application of a catalyst shows a slight but consistent increase in carbon to gas conversion at higher temperatures $\left(785-879{ }^{\circ} \mathrm{C}\right)$. The hydrogen yield, syngas, and carbon dioxide gas production are much higher. $\mathrm{C}_{2}-\mathrm{C}_{3}$ gas production is significantly lowered relative to noncatalytic pyrolysis oil conversion. The methane production is unaffected while a lower methane production could be suggested in the midtemperature region $\left(703-751^{\circ} \mathrm{C}\right)$.

Pyrolysis oil seems to undergo an increasing conversion to permanent gases with temperature due to cracking, which is complete around $700{ }^{\circ} \mathrm{C}$. In the lower temperature region, a substantial amount of liquid product is obtained, which is partly dissolved in and partly separated from the water condensate. This liquid phase consists of formed tars (secondary and tertiary) and unconverted pyrolysis oils components (primary tars). This can be seen in $\mathrm{C}_{2}-\mathrm{C}_{3}$ gas production, which is an indication for the presence of secondary and tertiary tars. Since it is low at low temperatures, indicating low secondary and tertiary tar production, the liquid product must come from unconverted or partially converted pyrolysis oil. When the pyrolysis oil is fully cracked, the $\mathrm{C}_{2}-\mathrm{C}_{3}$ gas production is highest (around $700{ }^{\circ} \mathrm{C}$ ). A further temperature increase converts the produced $\mathrm{C}_{2}-\mathrm{C}_{3}$ compounds. 
The equilibrium catalyst is unable to effectively convert methane and secondary and tertiary tars. Methane is known for being a very stable compound and can only be converted by very active catalysts or high temperatures $[5,25]$. The catalyst still has a very high water gas shift activity, as seen in the enhanced carbon dioxide gas production and hydrogen yield. Besides water gas shift activity, the catalyst still enhances other reactions. The syngas production, which is independent of the extent of the water gas shift reaction, is overall much higher. The following reactions seem to be also enhanced:

- $\mathrm{C}_{2}-\mathrm{C}_{3}$ reforming. A clear lower $\mathrm{C}_{2}-\mathrm{C}_{3}$ gas production (Figure 2.5F) is seen when using a catalyst.

- Carbon gasification. This cannot directly be seen from the results presented. However, the carbon to gas conversion is higher when using a catalyst, while no secondary and tertiary tar conversion has been observed. Additionally, burnoff experiments have shown that on average less carbon stays in the bed when using a catalyst $(\sim 7 \%)$ than when using a sand $(\sim 11 \%)$ bed. Also, the literature $[18,26]$ states that carbon gasification can be enhanced by catalyst supports containing potassium.

(A)

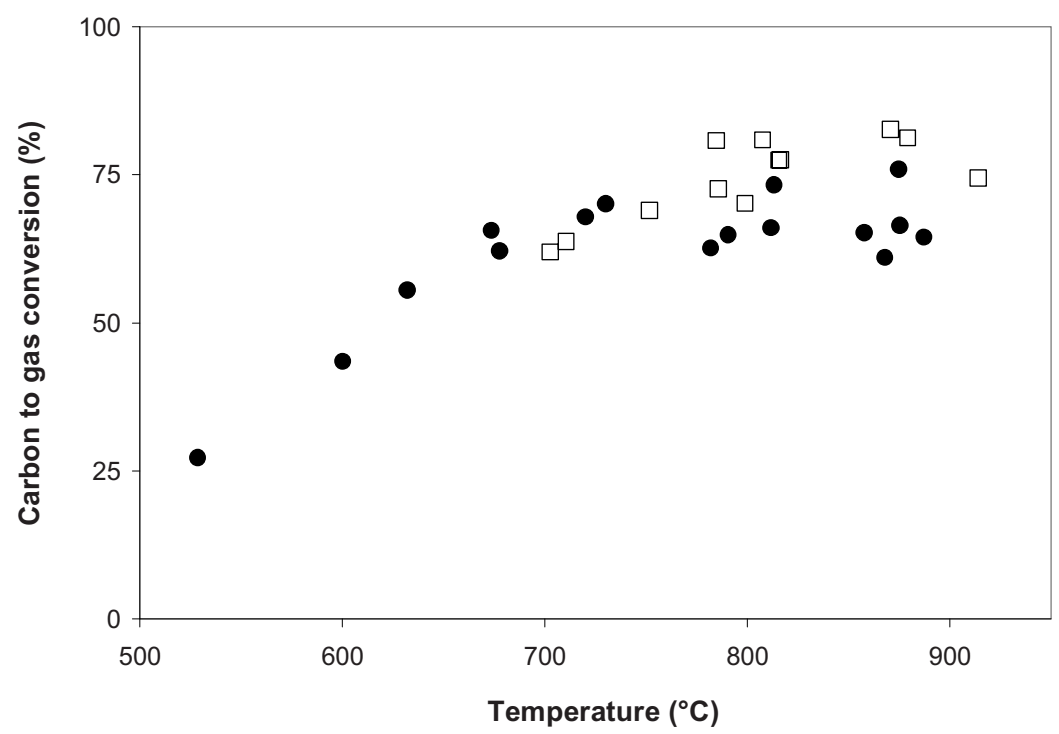


Chapter 2

(B)

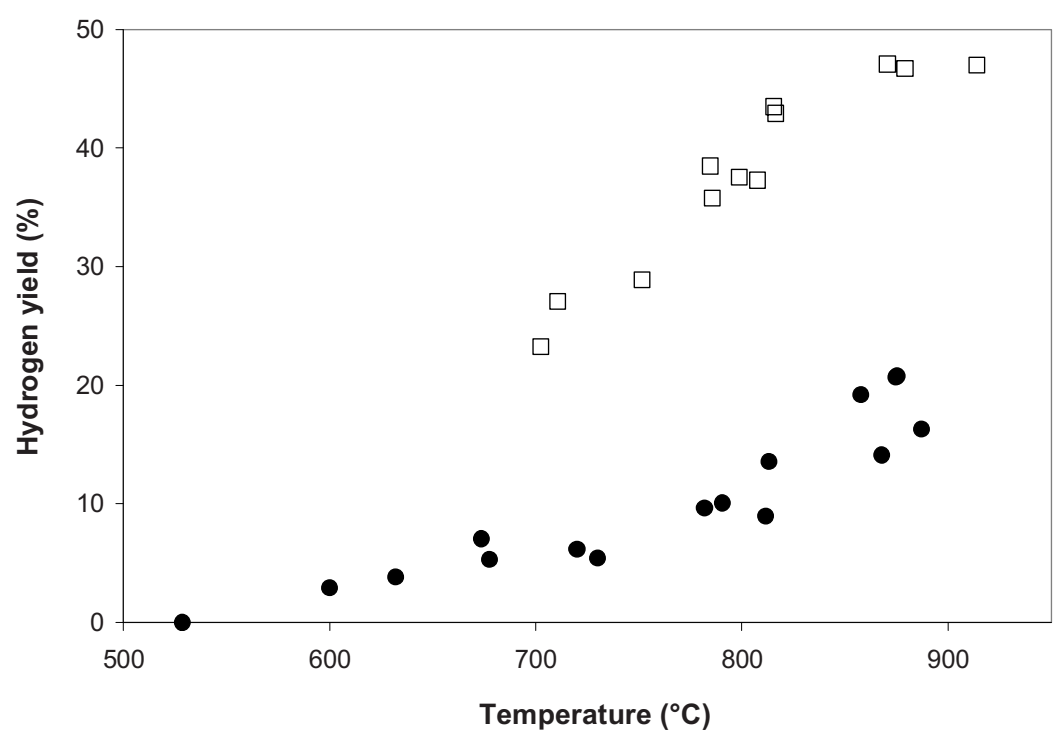

(C)

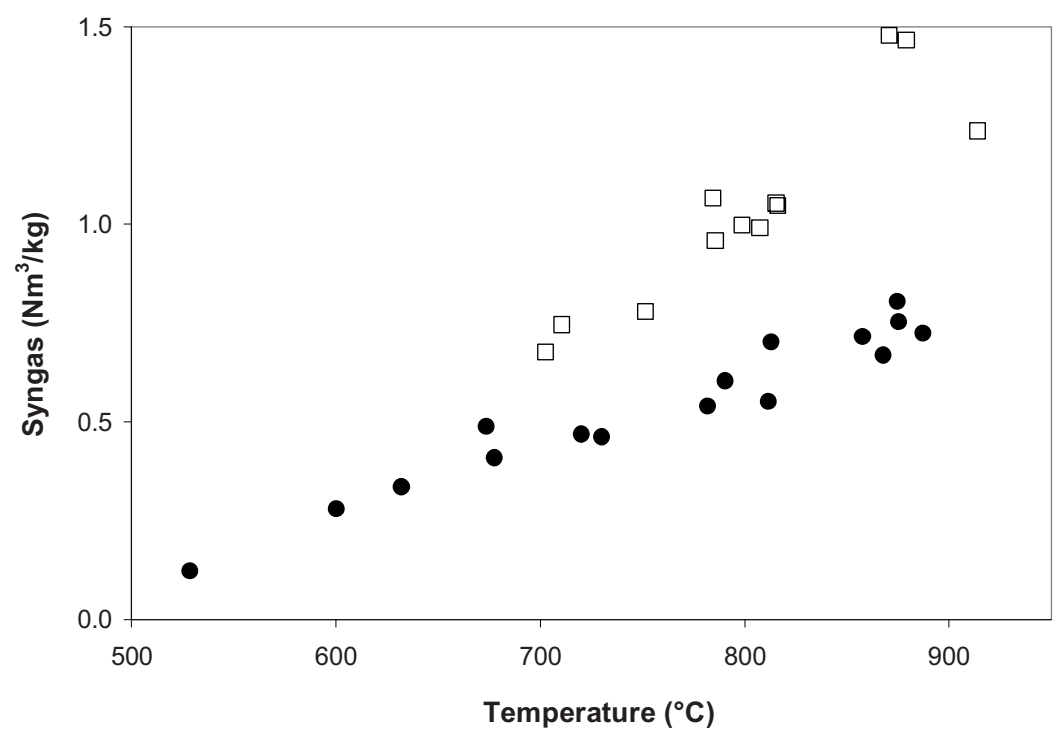


(D)

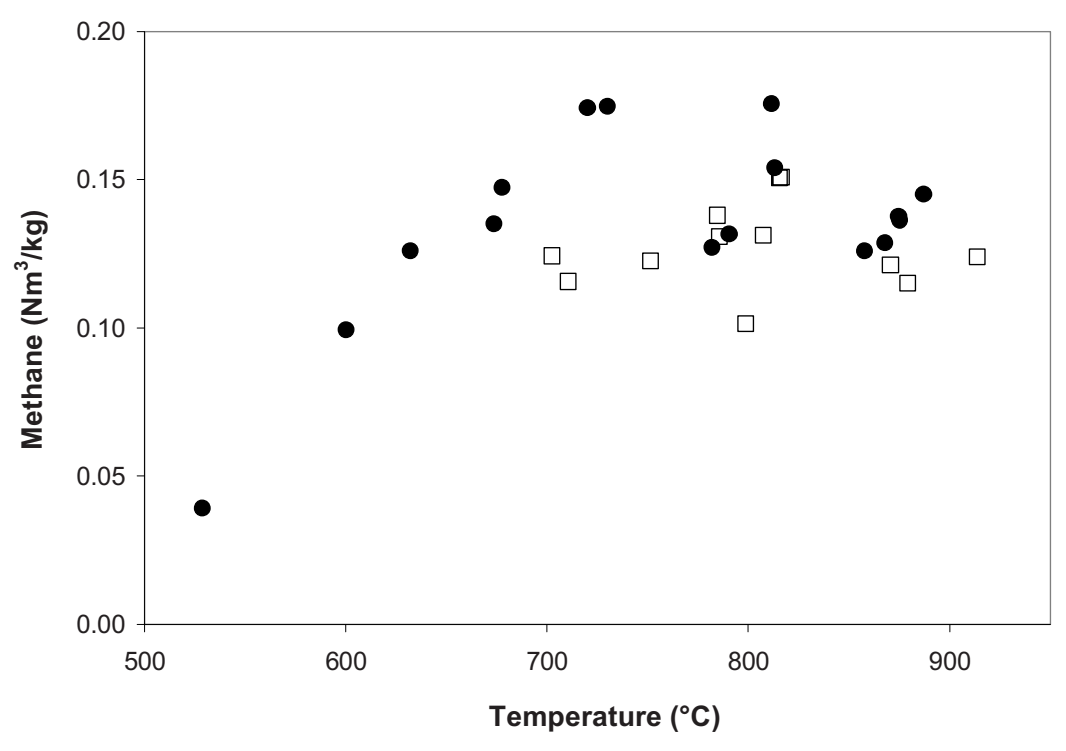

(E)

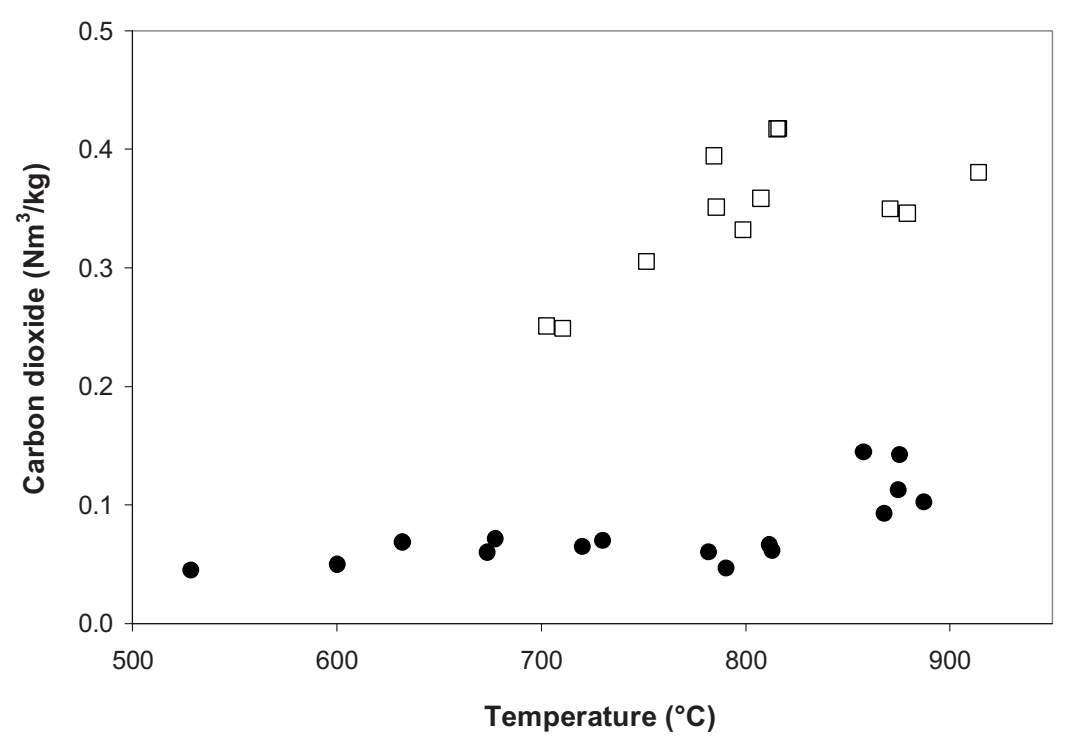


(F)

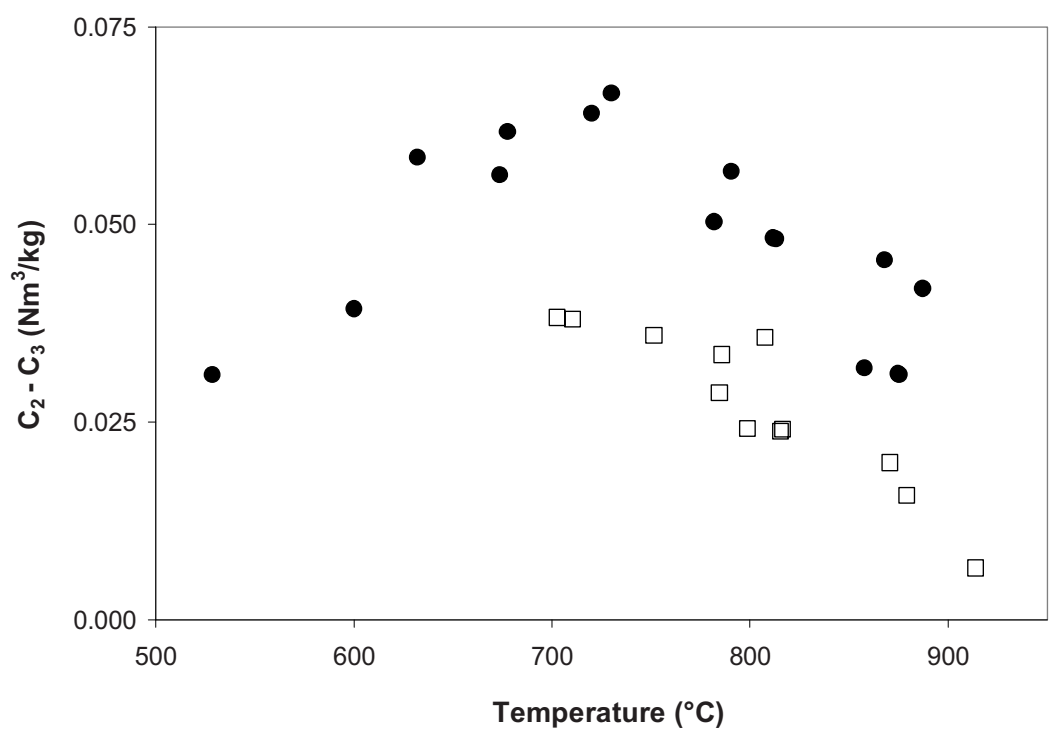

Figure 2.5. Experimental results of FB catalytic $(\square)$ and noncatalytic $(\bullet)$ pyrolysis oil gasification versus temperature: (A) carbon to gas conversion, (B) hydrogen yield, (C) syngas (hydrogen plus carbon monoxide) production, (D) methane production, (E) carbon dioxide production, $(\mathrm{F}) \mathrm{C}_{2}-\mathrm{C}_{3}$ (ethylene, ethane, propylene, and propane) production; total pyrolysis oil flow $=0.35-0.64$, $1.41-1.81 \mathrm{~kg} / \mathrm{h}$ (beech and pine, wet basis); $\mathrm{S} / \mathrm{C}$ ratio $=1.0-1.9,2.6-3.3$; run time $=0.4-3.0 \mathrm{~h}$; nitrogen flow $=10-20 \mathrm{~nL} / \mathrm{min}$; equivalence ratio $=0 \%$.

\subsubsection{Other Parameters Varied}

Besides the temperature, which was varied over a wide range, other parameters were varied to investigate their impact. A summary of experiments is shown in Table 2.2, which are described below.

Because the FB catalyst (Table 2.2, column 3) showed activity loss during pyrolysis oil gasification, also a mixture of sand and commercial naphtha reforming catalyst was tested (KATALCO 46, Table 2.2, column 5) in the fluidized bed. This catalyst showed similar activity loss but more gradually in time and maintaining some methane conversion even at a lower catalyst loading used ( 0.3-0.4 kg catalyst, $4.5 \mathrm{~kg}$ sand). The catalyst is however not designed for fluidization, which makes accurate testing more 
difficult since particle size and shape vary a lot due to the grinding of the catalyst and attrition is relatively high.

The amount of bed material (4-9 kg) and catalyst loading (FB, 1-4 kg) was also varied in the fluidized bed for some experiments. No trend was however found in the results, indicating that the reactor was charged sufficiently for the reactions to fully proceed.

The addition of air (Table 2.2, columns 2, 4, and 6) increased the carbon to gas conversion significantly. Hydrogen and methane gas productions were lowered with increasing carbon monoxide and carbon dioxide productions typical for single vessel air blown gasifiers. When catalysts were used, no additional activity loss was observed in time due to the presence of oxygen.

For noncatalytic gasification (Figure 2.5 ), also the $\mathrm{S} / \mathrm{C}$ ratio was varied. While most experiments were done with a relatively low $\mathrm{S} / \mathrm{C}$ ratio (1.0-1.2), also higher ratios were used (1.8-3.1 at $790,858,875,868$, and $\left.887^{\circ} \mathrm{C}\right)$. The higher $\mathrm{S} / \mathrm{C}$ ratio points are close to the trend seen in the Figures and close to points which used the lower S/C ratio $(782,812$, 813 , and $875^{\circ} \mathrm{C}$ ). Therefore, it can be concluded that for noncatalytic gasification the $\mathrm{S} / \mathrm{C}$ ratio has no significant impact.

Table 2.2. Various experimental data showing different types of bed material and air additions.

\begin{tabular}{|c|c|c|c|c|c|c|c|}
\hline & 1 & 2 & 3 & 4 & 5 & 6 & 7 (2 stage) \\
\hline Feed type & Pine oil & Beech oil & Beech oil & Beech oil & Beech oil & Beech oil & Pine oil \\
\hline Bed type & Sand & Sand & $\mathrm{FB}$ & FB & K46 & K46 & Sand $\mathrm{K} 46+23$ \\
\hline Temperature $\left({ }^{\circ} \mathrm{C}\right)$ & 790 & 835 & 816 & 813 & 809 & 855 & 810 \\
\hline $\mathrm{S} / \mathrm{C}$ & 1.9 & 1.0 & 3.1 & 3.2 & 3.2 & 2.1 & 1.5 \\
\hline$\lambda(\%)$ & 0 & 23 & 0 & 26 & 0 & 23 & 0 \\
\hline Carbon to gas (\%) & 65 & 87 & 78 & 88 & 76 & 91 & 85 \\
\hline $\mathrm{H}_{2}$ yield $(\%)$ & 10 & 15 & 43 & 38 & 46 & 40 & 68 \\
\hline & \multicolumn{7}{|c|}{ Gas production $\left(\mathrm{Nm}^{3} / \mathrm{kg}\right)$} \\
\hline $\mathrm{H}_{2}$ & 0.23 & 0.31 & 0.88 & 0.78 & 0.93 & 0.91 & 1.52 \\
\hline $\mathrm{CO}$ & 0.38 & 0.40 & 0.17 & 0.27 & 0.32 & 0.40 & 0.58 \\
\hline $\mathrm{CH}_{4}$ & 0.13 & 0.12 & 0.15 & 0.10 & 0.09 & 0.08 & 0.00 \\
\hline $\mathrm{CO}_{2}$ & 0.05 & 0.22 & 0.42 & 0.46 & 0.32 & 0.44 & 0.29 \\
\hline \multirow[t]{2}{*}{$\mathrm{C}_{2}-\mathrm{C}_{3}$} & 0.06 & 0.04 & 0.02 & 0.02 & 0.02 & 0.02 & 0.00 \\
\hline & \multicolumn{7}{|c|}{ Gas composition (vol\%) } \\
\hline $\mathrm{H}_{2}$ & 26.8 & 27.8 & 52.8 & 46.7 & 55.5 & 48.2 & 62.6 \\
\hline $\mathrm{CO}$ & 44.7 & 36.5 & 10.2 & 16.2 & 19.3 & 21.2 & 23.9 \\
\hline $\mathrm{CH}_{4}$ & 15.6 & 10.5 & 9.1 & 6.2 & 5.4 & 4.1 & 0.0 \\
\hline $\mathrm{CO}_{2}$ & 5.6 & 20.1 & 25.1 & 27.4 & 19.0 & 23.1 & 11.9 \\
\hline $\mathrm{C}_{2}-\mathrm{C}_{3}$ & 6.7 & 3.6 & 1.4 & 1.5 & 1.0 & 0.8 & 0.0 \\
\hline
\end{tabular}




\subsubsection{Two Stage Reactor Concept}

The results presented up to now suggest that methane and tar free syngas cannot be produced from pyrolysis oil at these temperatures using a fluidized bed. For this, an optimal catalyst, which combines high activity and mechanical strength, should be developed. Besides catalyst problems, gas channeling through the fluidized bed will always be a source of impurities in the gas.

Decoupling of pyrolysis oil re-evaporation/gasification and gas upgrading to syngas seems promising in a two beds in series concept, combining a fluidized and fixed bed:

- Fixed bed commercial catalysts can be directly used which have been proven to be active and do not need additional mechanical strength for fluidization.

- Pyrolysis oil re-evaporation can be done at a lower temperature than the catalytic conversion to syngas, which is beneficial to the overall exergy efficiency of the process.

- Primary pyrolysis oil conversion seems to be mainly thermally driven, followed by catalytic gas upgrading. Actual splitting of these two processes makes separate optimization possible.

- Formed carbonaceous deposits and particles can be separated before the catalytic fixed bed, making energy utilization possible by burning the carbon.

For examining this concept, the setup was modified to a two-bed system. In the freeboard of the fluidized bed, a fixed bed was installed comprised of naphtha (K46) and methane (K23) steam reforming commercial catalyst. Figure 2.6 shows a long duration run which was done with this setup configuration showing a constant gas production. A clean syngas was produced for more than $11 \mathrm{~h}$, over which time period no overall catalyst activity loss was observed. No methane and $\mathrm{C}_{2}-\mathrm{C}_{3}$ components were detected; SPA analyses show a low tar content of $\sim 0.5 \mathrm{~g} / \mathrm{kg}\left(0.2 \mathrm{~g} / \mathrm{Nm}^{3}\right)$. The carbon to gas conversion was high $(85 \%)$ with a total carbon recovery of $90 \%$ including burnoff. However, some small carbonaceous particulates were still present in the product gas. The gas, after subtracting the $15 \%$ carbon not converted to permanent gases, is at chemical equilibrium (experiment Table 2.2, column 7; equilibrium composition hydrogen $61.2 \%$, carbon monoxide $24.9 \%$, and carbon dioxide $14.0 \%$ ). 


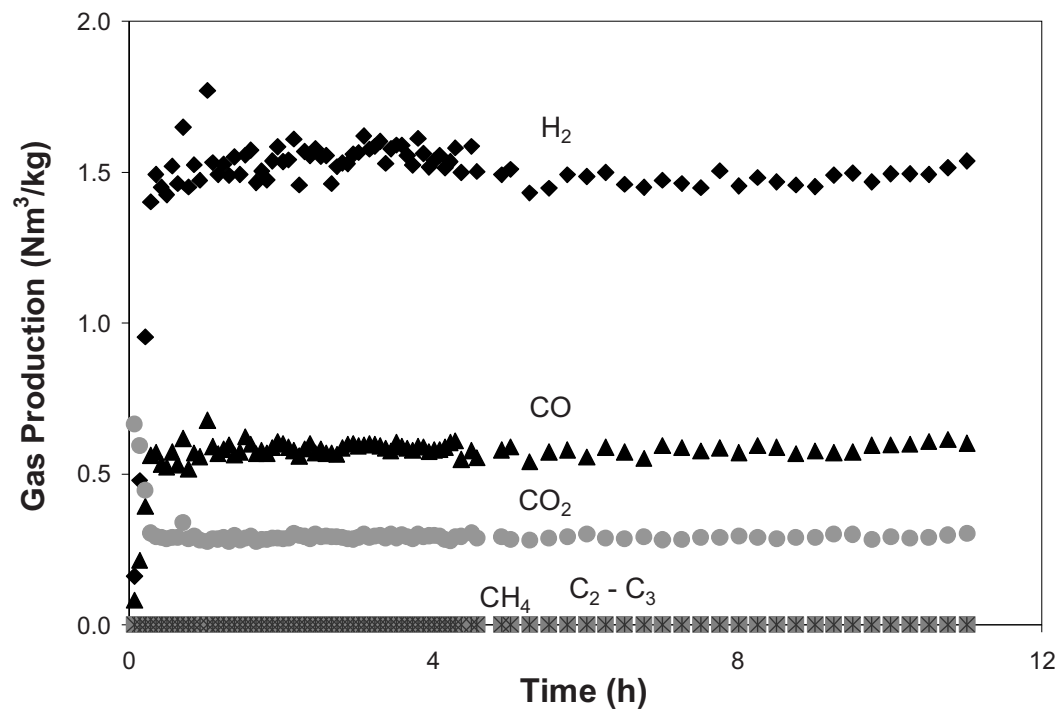

Figure 2.6. Gas production of two beds in series for pyrolysis oil gasification versus time: pyrolysis oil flow $=0.43 \mathrm{~kg} / \mathrm{h}$ (pine, wet basis); temperature $=805$ (fluidized bed), $815^{\circ} \mathrm{C}$ (fixed bed); $\mathrm{S} / \mathrm{C}$ ratio $=1.5 ;$ nitrogen flow $=10 \mathrm{~nL} / \mathrm{min}$; sand fluidized bed loading $=5.0 \mathrm{~kg}$; catalyst fixed bed loading $=2.5 \mathrm{~kg} \mathrm{~K} 46,5.1 \mathrm{~kg} \mathrm{~K} 23$; hydrogen yield = 68\%; carbon to gas conversion $=85 \%$. 


\subsection{Conclusions}

The conclusions of this Chapter can be summarized as follows:

- Clean syngas production from biomass, via pyrolysis oil as an intermediate, is viable at moderate reaction temperatures $\left(\mathrm{T} \sim 800^{\circ} \mathrm{C}\right)$ using a catalyst.

- In this process, the pyrolysis oil undergoes evaporation and thermal cracking after which the catalyst conditions the produced gases and vapors.

- Both the specially designed fluidizable (FB) and the commercial (KATALCO 46) nickel catalysts show activity loss in a fluid bed which results in an equilibrium activity with methane and $\mathrm{C}_{2}-\mathrm{C}_{3}$ slip.

- A two-bed concept, using a fluid sand bed followed by a fixed catalytic bed, results in methane and $\mathrm{C}_{2}-\mathrm{C}_{3}$ free syngas $\left(2.1 \mathrm{Nm}^{3} \mathrm{CO}+\mathrm{H}_{2} / \mathrm{kg}\right.$ dry pyrolysis oil, $\mathrm{H} 2 / \mathrm{CO}=2.6)$ with a low tar content $\left(0.2 \mathrm{~g} / \mathrm{Nm}^{3}\right.$; dry and nitrogen free $)$.

- Decoupling of the evaporation, primary pyrolysis oil conversion, and gas conditioning is beneficial for the overall energetic efficiency and allows the separate optimization of the processes. 


\section{References}

1. Bridgwater, A. V. Fast pyrolysis of biomass: A Handbook; CPL Press: Berkshire, United Kindom, 2005.

2. Czernik, S.; Bridgwater, A. V. Overview of applications of biomass fast Pyrolysis oil. Energy Fuels 2004, 18, 590.

3. Den Uil, H.; Van Ree, R.; Van der Drift, B.; Boerrigter, H. Duurzaam synthesegas: Een brug naar duurzame energie- en grondstoffenVoorziening; ECN-C-04-015, Energy research Centre of the Netherlands, 2004.

4. Levenspiel, O. What will come after petroleum. Ind. Eng. Chem. Res. 2005, 44, 5073.

5. Higman, C.; Van der Burgt, M. Gasification; Elesevier Science: New York, 2003.

6. Rostrup-Nielsen, J. R.; Sehested, J.; Nørskov, J. K. Hydrogen and synthesis gas by steamand $\mathrm{CO} 2$ reforming. Adv. Catal. 2002, 47, 66.

7. Dinjus, E.; Henrich, E.; Schingnitz, M. Syngas from the gasification of biomass slurries-a progress report. Proceedings of the 14th European Biomass Conference, Paris, France, October 17-21, 2005, 1663.

8. Energy research Centre of the Netherlands. Phyllis database. http://www.ecn.nl/phyllis/, (last accessed October 2006)

9. Panigrahi, S.; Dalai, A. K.; Chaudhari, S. T.; Bakshi, N. N. Synthesis gas production from steam gasification of biomass-derived oil. Energy Fuels 2003, 17, 637.

10. Czernik, C.; French, R.; Feik, C.; Chornet, E. Hydrogen by catalytic steam reforming of liquid byproducts from biomass thermoconversion processes. Ind. Eng. Chem. Res. 2002, $41,4209$. 
11. Kechagiopoulos, P. N.; Voutetakis, S. S.; Lemonidou, A. A.; Vasalos, I. A. Hydrogen production via steam reforming of the aqueous phase of bio-oil in a fixed bed reactor. Energy Fuels 2006, 20, 2155.

12. Basagiannis, A. C.; Verykios, X. E. Reforming reactions of acetic acid on nickel catalysts over a wide temperature range. Appl. Catal. A 2006, 308, 182.

13. Wang, D.; Montané, D.; Chornet, E. Catalytic steam reforming of biomass-derived oxygenates: acetic acid and hydroxyacetaldehyde. Appl. Catal. A 1996, 143, 245.

14. Marquevich, M.; Farriol, X.; Medina, F.; Montane', D. Hydrogen production by steam reforming of vegetable oils using nikel-based catalysts. Ind. Eng. Chem. Res. 2001, 40, 4757.

15. Galdámez, J. R.; Garcia, L.; Bibao, R. Hydrogen production by steam reforming of biooil using coprecipitated Ni-Al catalysts. Acetic acid as a model compound. Energy Fuels $2005,19,1133$.

16. Garcia, L.; French, R.; Czernik, S.; Chornet, E. Catalytic steam reforming of bio-oils for the production of hydrogen: effects of catalyst composition. Appl. Catal. A 2000, 201, 225.

17. Rioche, C.; Kulkarni, S.; Meunier, F. C.; Breen, J. P.; Burch, R. Steam reforming of model compounds and fast pyrolysis bio-oil on supported noble metal catalysts. Appl. Catal. B 2005, 61, 130.

18. Davidian, T.; Guilhaume, N.; Iojoiu, E.; Provendier, H.; Mirodatos, C. Hydrogen production from crude pyrolysis oil by a sequential catalytic process. Appl. Catal. B $2007,73,116$.

19. Takanabe, K.; Aika, K.; Inazu, K.; Baba, T.; Seshan, K.; Lefferts, L. Steam reforming of acetic acid as a biomass derived oxygenate: Bifunctional pathway for hydrogen formation over Pt/ZrO2 catalysts. J. Catal. 2006, 243, 263. 
20. Evans, R. J.; Czernik, S.; French, R.; Magrini, K. Distributed bio-oil reforming; IV.A.13, DOE Hydrogen Program FY 2005 Progress Report, 2005.

21. Magrini-Bair, K.; Czernik, S.; French, R.; Parent, Y.; Ritland, M.; Chornet, E. Fluidizable catalysts for producing hydrogen by steam reforming biomass pyrolysis liquids. Proceedings of the 2002 U.S. DOE Hydrogen Program Review, Golden, Colorado, May 6-10, 2002; NREL/CP-610-32405.

22. Van Rossum, G.; Kersten, S. R. A.; Prins, W.; Van Swaaij, W. P. M. System configurations for the conversion of bio-oil to fuel cell electricity. Proceedings of the 2nd World Conference on Biomass for Energy, Industry and Climate Protection, Rome, Italy, May 10-14, 2004, 1179.

23. Evans, R. J.; Czernik, S.; French, R.; Marda, J. Distributed bio-oil reforming. Proceedings of the DOE Hydrogen, Fuel Cells \& Infrastructure Technologies Program Review, Arlington, Virginia, May 16, 2006, ID\#PD5.

24. Kersten, S. R. A.; Prins, W.; Van der Drift, A.; Van Swaaij, W. P. M. Experimental factfinding in CFB biomass gasification for ECN's $500 \mathrm{kWth}$ pilot plant. Ind. Eng. Chem. Res. 2003, 42, 6755 .

25. Jess, A. Thermische und katalytische Spaltung von Kohlenwasserstoffen in wasserstoffund wasserdampfreicher Atmosphäre. Habilitationsschrift, Universität Karlsruhe, Karlsruhe, Germany, 1996.

26. Menon, P. G. Coke on catalysts - harmful, harmless, invisible and beneficial types. $J$. Mol. Catal. 1990, 59, 207.

27. Branca, C.; Giudicianni, P.; Di Blasi, C. GC/MS characterization of liquids generated from low-temperature pyrolysis of wood. Ind. Eng. Chem. Res. 2003, 42, 3190.

28. Oasmaa, A.; Meier, D. Pyrolysis liquids analyses; the results of IEA-EU round robin. Fast Pyrolysis of Biomass: A Handbook Volume 2; Bridgwater, A.V., CPL Press: Newbury, U.K., 2002, 41. 


\title{
Chapter 3
}

\author{
Staged Catalytic Gasification/Steam Reforming \\ of Pyrolysis Oil
}

\begin{abstract}
Gasification/steam reforming of pyrolysis oil was studied in a staged reactor concept, which consisted of an inert fluidized bed and a catalytic fixed bed. Methane and $C_{2}-C_{3}$ free syngas is produced at a single temperature around $800^{\circ} \mathrm{C}$ at atmospheric pressure. By lowering the temperature of the fluidized bed $\left(432-500{ }^{\circ} \mathrm{C}\right)$, its function is changed from a gasifier to an evaporator, and in this way the subsequent catalyst bed actually sees vaporized pyrolysis oil compounds (instead of a fuel gas), which it can more readily convert to syngas. However, the temperature of the fixed bed cannot be too low (min $700{ }^{\circ} \mathrm{C}$ ) to avoid excessive carbon deposition. System calculations show that when pressurized (30 bar) pyrolysis oil gasification/reforming is considered, the catalytic exit bed temperature should be high (900-1000 $\left.{ }^{\circ} \mathrm{C}\right)$ to reach sufficient enough methane conversion when syngas is the desired product. When only steam is added at elevated pressure, the $\mathrm{H}_{2} / \mathrm{CO}$ ratio readily increases, which is desired for hydrogen production. For other applications (e.g. Fischer-Tropsch), carbon dioxide probably has to be recycled to keep the $\mathrm{H}_{2} / \mathrm{CO}$ ratio around 2-3. The lower heating value efficiency of pyrolysis oil gasification/reforming is comparable to the lower end of the reported range of commercial methane steam reforming.
\end{abstract}

Adapted from:

Van Rossum, G.; Kersten, S.R.A.; Van Swaaij, W.P.M. Ind. Eng. Chem. Res. 2009, 48, 5857. 


\subsection{Introduction}

Pyrolysis oil is an interesting intermediate biobased energy carrier because of its high volumetric energetic density and low ash content as compared to the original biomass source. However, due to the type of components present in pyrolysis oil, its high oxygen and water content direct applications of pyrolysis oil are, at present, limited to heat and power production besides niche applications like food flavoring and extraction of specialty chemicals [1]. To upgrade the pyrolysis oil to chemicals and transportation fuels, three major routes can be identified: (i) direct improvement of the pyrolysis oil during production (e.g. catalytic pyrolysis [2] and staged condensation [3]), (ii) pyrolysis oil upgrading via decarboxylation and/or hydrogenation [4], and (iii) upgrading via syngas (hydrogen and carbon monoxide) production. In this Thesis, gasification (reforming) of pyrolysis oil to syngas is considered.

Syngas [5] is widely used for the production of heat and power $(\sim 4 \%)$, ammonia ( $\sim 53 \%)$, methanol $(\sim 11 \%)$, hydrogen for refineries $(\sim 24 \%)$, and transportation fuels $(\sim 8 \%)$ with a worldwide production of $6 \mathrm{TJ} /$ year in $2003[6]$.

The most straightforward method to produce synthesis gas from biomass is via high temperature entrained flow gasification [7]. However, this gasification technology has a few disadvantages.

- Because of the severity of the process and the pure oxygen that is needed, high temperature gasification can only be applied economically on a very large scale (500 MW or higher). For stand-alone biobased syngas production, such high capacities are logistically cumbersome when raw biomass from the fields is considered. Biomass densification techniques (pyrolysis, hydrothermal liquefaction, and pelletization with or without torrefaction) are a solution for the mismatch between the locations where the biomass is available and where the products are required.

- The minerals and metals that are present in the biomass are converted to slag when solid or slurry biomass entrained flow gasification is being applied. While the slag can be used in the current industry infrastructure as a construction material, upscaling of biomass utilization will lead to land depletion because the 
mineral and metal balances are not closed. Low temperature conversion processes result in ash, which in principle can be recycled back to the ground.

- Operating at very high temperatures lowers the energetic efficiency, especially for biomass with its low heating value of maximally $20 \mathrm{MJ} / \mathrm{kg}$ (wet basis).

To produce a clean syngas (low in tar and methane) at moderate process temperatures $\left(<950{ }^{\circ} \mathrm{C}\right)$, various research groups have studied the application of catalysts for biomass gasification [8]. Lowering the temperature and refraining from the need for pure oxygen for the gasifier reduces equipment costs and allows for gasification at smaller scale. Up until now, syngas production in catalytic gasifiers taking in solid biomass has always needed downstream catalytic gas/vapor conversion steps [9].

Advantages of converting biomass derived liquids rather than biomass itself are that a liquid is easier to handle, store, and transport, its volumetric energy density is much higher, and it contains lower level of catalysts poisoning species as compared to the biomass source it is derived from. Czernick et al. [10] have shown that the fraction of pyrolysis oil that dissolves in water can be gasified with a nickel catalyst to hydrogenrich gas at around $850{ }^{\circ} \mathrm{C}$. The steam over carbon ratio used $(\sim 7)$ was, however, high.

Van Rossum et al. [11] have started research on low temperature gasification (500-900 ${ }^{\circ} \mathrm{C}$ ) of the whole pyrolysis oil in a fluidized bed both catalytically and noncatalytically. Noncatalytically, a fuel gas $\left(\mathrm{H}_{2}, \mathrm{CO}, \mathrm{CO}_{2}, \mathrm{H}_{2} \mathrm{O}, \mathrm{CH}_{4}, \mathrm{C}_{2}-\mathrm{C}_{3}\right.$, and tars $)$ is produced because, besides thermal cracking, other reactions hardly occur. The catalytic fluidized bed suffers from severe irreversible deactivation, leading after a short period also to fuel gas instead of the desired synthesis gas. Pursuing a single reactor conversion has the advantage that it is a simple and compact process. However, application of a catalytic fluidized bed for gasification of bioliquids has up until now not yet been successful due to activity loss of the catalyst [10,11]. Recently [12,13], catalyst development focusing on both activity and mechanical stability showed embryonic, although encouraging, results. However, a disadvantage of a fluidized bed reactor is that it operates at a single high temperature, and both evaporation and the endothermic reforming take place in a single vessel, which requires a very high single heat duty. To overcome these disadvantages of a single fluidized bed reactor concept, a staged reactor concept has been proposed by Van Rossum et al. [11] (see Chapter 2). It consists of an inert fluidized bed for oil atomization/evaporation followed by a fixed catalytic bed for 
conversion of pyrolysis oil derived vapors and gases. Initial testing [11] has shown that methane and $\mathrm{C}_{2}-\mathrm{C}_{3}$ free syngas $\left(2.1 \mathrm{Nm}^{3} / \mathrm{kg}\right.$ of dry pyrolysis oil) can be produced at $815^{\circ} \mathrm{C}$ (fixed and fluid bed) with low tar content $\left(\sim 0.5 \mathrm{~g} / \mathrm{kg}\right.$ dry oil, $\left.0.2 \mathrm{~g} / \mathrm{Nm}^{3}\right)$.

In this Chapter, the process conditions of the staged system are varied to map the operating window. Additionally, several layouts of a process are proposed and discussed. Process alternatives are compared by gross mass and energy balance calculations.

\subsection{Experimental Section}

\subsubsection{Materials}

Four different liquid feedstocks were used, of which the elemental composition and water content are given in Table 3.1. The pyrolysis oils used were produced in the pilot plant facility $(200 \mathrm{~kg} / \mathrm{h})$ of the company BTG, The Netherlands. The two residual sugar streams were provided by Purac, The Netherlands. The different batches of pyrolysis oil used varied mainly in the water content; the dry elemental composition is more or less constant.

Two commercial nickel $(15-25 \% \mathrm{NiO})$ on alumina fixed bed KATALCO catalysts were supplied by Johnson Matthey: 23-4Q (K23: methane reforming) and 46-3Q (K46: naphtha reforming). The catalysts were used without crushing, while the shape consisted of a 4-hole domed cylinder with the following geometrics: K23, length $19 \mathrm{~mm}$, diameter $14 \mathrm{~mm}$; K46, length $15 \mathrm{~mm}$, diameter $16.5 \mathrm{~mm}$. 
Chapter 3

Table 3.1. Elemental analyses and water content determinations of the pyrolysis oils and sugar stream used. ${ }^{\text {a }}$

\begin{tabular}{|c|c|c|c|c|}
\hline$(w t \%)$ & Beech wood & Pine wood & 'Light' sugar & 'Heavy' sugar \\
\hline & pyrolysis oil & pyrolysis oil & waste stream & waste stream \\
\hline $\mathbf{C}$ & 38.4 & $34.1-39.9$ & 36.6 & 37.2 \\
\hline $\mathbf{H}$ & 8.0 & $7.7-8.4$ & 6.7 & 7.1 \\
\hline Rest & 53.6 & $51.8-58.2$ & 56.6 & 53.0 \\
\hline $\mathrm{H}_{2} \mathrm{O}$ & 32.0 & $29.7-34.1$ & 15.4 & 12.7 \\
\hline
\end{tabular}

${ }^{\mathrm{a}}$ The rest is mainly oxygen with also trace compounds like sulfur, nitrogen, and ash.

\subsubsection{Setups}

A schematic overview of the gasification setup is given in Figure 3.1. The pyrolysis oil and sugar waste stream were fed with a rate between $0.2-2.5 \mathrm{~kg} / \mathrm{h}$ via a gas $\left(\mathrm{N}_{2}\right)$ assisted atomizer. Additional gases $\left(\mathrm{H}_{2}, \mathrm{~N}_{2}\right.$, air, and $\left.\mathrm{CO}_{2}\right)$ and steam were added in an upward flow around the atomizer. In the fluidized bed, sand was used as an 'inert' bed material $(\mathrm{dp} \approx 150-450 \mu \mathrm{m})$. The fixed bed consisted of the steam reforming catalysts, which were used as received after reducing them with hydrogen. Sometimes, a layer of ceramic spheres $(\mathrm{dp} \approx 2 \mathrm{~cm})$ was placed upstream of the catalyst to minimize direct contact between the catalyst and fluidizing material. The calculated adiabatic temperature drop of the gas fed to the fixed bed is $\sim 150{ }^{\circ} \mathrm{C}$ at a fluid and fixed bed temperature of $\sim 800{ }^{\circ} \mathrm{C}$, assuming a noncatalytic gas composition (including steam and nitrogen) taken from Chapter 2 and chemical equilibrium after the fixed bed. The maximum radial temperature gradient necessary to counter balance the heat demand of the endothermic reactions in the fixed bed is estimated to be around $-30{ }^{\circ} \mathrm{C}$ using the correlations described in ref [14] (p 622 and further) including radiative heat transfer. In practice, however, most of the time a temperature increase $\left(\sim 25^{\circ} \mathrm{C}\right)$ was observed over the fixed bed. Apparently, the heat demand required for the reaction is easily compensated by the ovens used. A detailed description of the setup and the experimental procedure can be found in Chapter 2. 
Thermogravimetric anaylsis (TGA) was carried out using a Mettler Toledo System (TGA/SDTA851e). The heating rate was $5{ }^{\circ} \mathrm{C} / \mathrm{min}$ with a gas flow of $60 \mathrm{ml} / \mathrm{min}$ of argon. The TGA was loaded with 6-8 mg of pyrolysis oil sample.

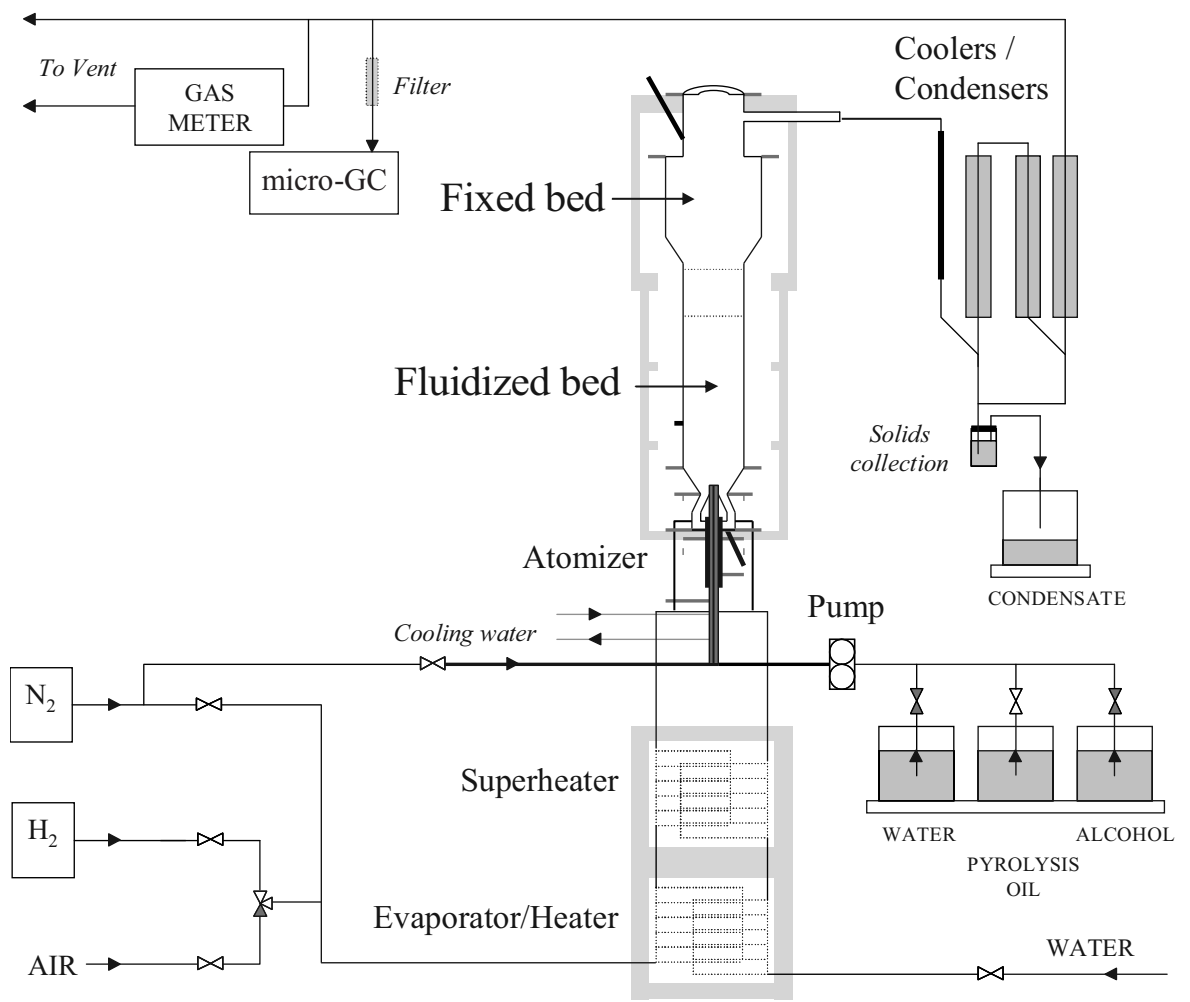

Figure 3.1. Schematic overview of the fluidized-bed setup.

\subsubsection{Definitions}

In the results presented, the carbon to gas conversion $\left(\mathrm{Y}_{\mathrm{C}}\right)$ is defined as the percentage of carbon from the feed converted to the following permanent gaseous products during gasification: $\mathrm{CH}_{4}, \mathrm{CO}, \mathrm{CO}_{2}$, and $\mathrm{C}_{2}-\mathrm{C}_{3}$ (defined as $\mathrm{C}_{2} \mathrm{H}_{4}, \mathrm{C}_{2} \mathrm{H}_{6}, \mathrm{C}_{3} \mathrm{H}_{6}$, and $\mathrm{C}_{3} \mathrm{H}_{8}$ ). The total carbon recovery is defined as the percentage of carbon that was converted during gasification and burnoff (from fluid and fixed bed) to permanent gases; in the setup used, it was not possible to realize separate burnoffs of the fluid and fixed 
bed, so always a total burnoff was done. The gas productions are defined as normal cubic meter $\left(0{ }^{\circ} \mathrm{C}\right.$ and $\left.1 \mathrm{~atm}\right)$ per kilogram of dry feed. The hydrogen yield is defined as the percentage of the maximum amount of hydrogen that can be produced according to the following reaction:

$\mathrm{C}_{x} \mathrm{H}_{y} \mathrm{O}_{z}+(2 x-z) \mathrm{H}_{2} \mathrm{O} \rightarrow x \mathrm{CO}_{2}+\left(\frac{y}{2}+2 x-z\right) \mathrm{H}_{2}$

The carbon to gas conversion, gas production, and hydrogen yield are calculated from steady-state operation and excluding startup. The total carbon recovery is the carbon to gas conversion plus the total integrated gas production (mainly $\mathrm{CO}_{2}$ ) during burnoff.

The steam over carbon ratio $(\mathrm{S} / \mathrm{C})$ is defined as the ratio of the total amount of moles of steam, including the water content of the feedstock, over moles of carbon in the feedstock. The (catalytic) $\mathrm{CH}_{4}$ and $\mathrm{C}_{2}-\mathrm{C}_{3}$ conversions are defined relative to noncatalytic fluid bed gasification at a similar temperature, which were reported in Chapter 2:

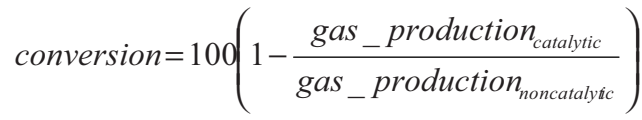

The gas hourly space velocity is defined as $\mathrm{C}_{1}$ equivalent carbon volume flow at standard conditions divided by the bulk volume of the catalyst $\left(\mathrm{G}_{\mathrm{Cl}} \mathrm{HSV}\right.$ in $\left.1 / \mathrm{h}\right)$. The contact time (s) is defined as the volume of catalyst divided by the combined produced gas, residual steam, and nitrogen flow at reactor temperature.

In the TGA experiments, the weight rate loss is defined as:

$r_{w}=-\frac{\left(m_{\tau}-m_{\tau+1}\right)}{m_{0}\left(T_{\tau}-T_{\tau+1}\right)} \quad\left(\frac{1}{{ }^{\circ} C}\right)$

where $\tau$ and $\tau+1$ are logged times, $\mathrm{T}\left({ }^{\circ} \mathrm{C}\right)$ is the temperature of the sample, and $\mathrm{m}_{0}(\mathrm{mg})$ is the initial amount of pyrolysis oil.

Chemical equilibrium calculations via minimizing the Gibbs free energy are described in ref [9] and were done for two different cases: equilibrium, total input 
(pyrolysis oil and steam); and carbon corrected equilibrium, total input minus the elemental carbon that is not converted to permanent gases during the gasification. Although char and tars will also contain hydrogen and oxygen, only a carbon corrected equilibrium was calculated because then experimental results can be used directly as input without having to make assumptions about the amount and type of char and/or vapor that is being produced. A similar approach has been applied with biomass gasification equilibrium models [15].

The internal standard (nitrogen) is not taken into account in the equilibrium calculation. Because at the measured conditions the equilibrium methane concentration is low, this results in only a negligible error caused by the pressure dependence of the methane steam reforming reaction.

\subsection{Experimental Results}

Several experiments at different fluidized and fixed bed temperatures were used, which will be described below.

\subsection{1 $T_{\text {fluidized bed }} \approx 600-800{ }^{\circ} \mathrm{C}, T_{\text {fixed bed }} \approx 800^{\circ} \mathrm{C}$}

In Chapter 2, we have reported one run with the two stage system with both temperatures around $800{ }^{\circ} \mathrm{C}$ leading to methane and $\mathrm{C}_{2}-\mathrm{C}_{3}$ free gas. In this run, the fixed bed consisted of first $5 \mathrm{~kg}$ of K46 catalyst followed by $2.5 \mathrm{~kg}$ of K23 catalyst. By comparing the results of further tests with $\mathrm{K} 46$ or K23 at otherwise identical conditions, we have not observed significant differences between these catalysts (results not shown here). Therefore, it has been decided only to use one of these catalysts in the remaining work, K46.

In this Chapter, it is investigated if the system also performs well with less catalyst than the $7.5 \mathrm{~kg}$ of the first successful runs. Figure 3.2 shows time loggings of two typical experiments, one using $5 \mathrm{~kg}$ of catalyst and one using $2.5 \mathrm{~kg}$ of catalyst. Figure 3.3 is a compilation of results and shows the influence of the space velocity $\left(\mathrm{G}_{\mathrm{C} 1} \mathrm{HSV}\right)$ on the conversion of $\mathrm{CH}_{4}$ and $\mathrm{C}_{2}-\mathrm{C}_{3}$ at a typical steam reforming temperature of $800{ }^{\circ} \mathrm{C}$. Conversion is here defined relative to the production of $\mathrm{CH}_{4} / \mathrm{C}_{2}-\mathrm{C}_{3}$ in the fluidized bed 
(see section definitions). The used $\mathrm{G}_{\mathrm{Cl}} \mathrm{HSV}$ in the range of $50-130 \mathrm{1} / \mathrm{h}$ are low as compared to industrial steam reforming of $\mathrm{CH}_{4}$ and naphtha, which are reported to be around $14501 / \mathrm{h}$ [16]. However, caution should be taken when comparing these data to both industrial as other pilot or micro scale data (e.g. ref [10]). The catalyst has been used as received where the shape of the catalyst has been optimized for commercial operation ( $\mathrm{p} \approx 35$ bar, $\mathrm{T} \approx 800{ }^{\circ} \mathrm{C}$ ) with high methane inlet concentrations $(\sim 25-35$ vol\%) and a low intrinsic catalytic activity $(\sim 10 \%)$. In our case, the inlet methane/fuel concentration is low ( $\sim$ vol\%, including steam and nitrogen) with also low intrinsic catalytic activities. Crushing the pellets would lead to a much higher intrinsic catalytic activity and thus higher space velocities because less catalyst has to be used to achieve certain conversions. On the other hand, the contact time in our catalytic bed (1.4-2.4 s) is actually somewhat lower than commercial steam reforming contact times, which are in the range of $4-5 \mathrm{~s}[16]$.

At $\mathrm{G}_{\mathrm{C} 1} \mathrm{HSV}$ above $90 \mathrm{1} / \mathrm{h}\left(2.5 \mathrm{~kg}\right.$ of catalyst), incomplete $\mathrm{CH}_{4}$ and $\mathrm{C}_{2}-\mathrm{C}_{3}$ conversion is observed (see Figures 3.2B and 3.3), which can be attributed to too low intrinsic activity of the catalyst or nonideal distribution of the catalyst particles leading to hydrocarbon slip. The contacting pattern in case of $2.5 \mathrm{~kg}$ catalyst loading is expected to be nonideal because the bed is shallow $\left(L / \mathrm{D}_{\text {bed }} \approx 1.7\right)$ and the number of particles per unit diameter is low $\left(\mathrm{D}_{\text {bed }} / \mathrm{D}_{\text {particle }} \approx 6-12\right)[14]$. 
(A)

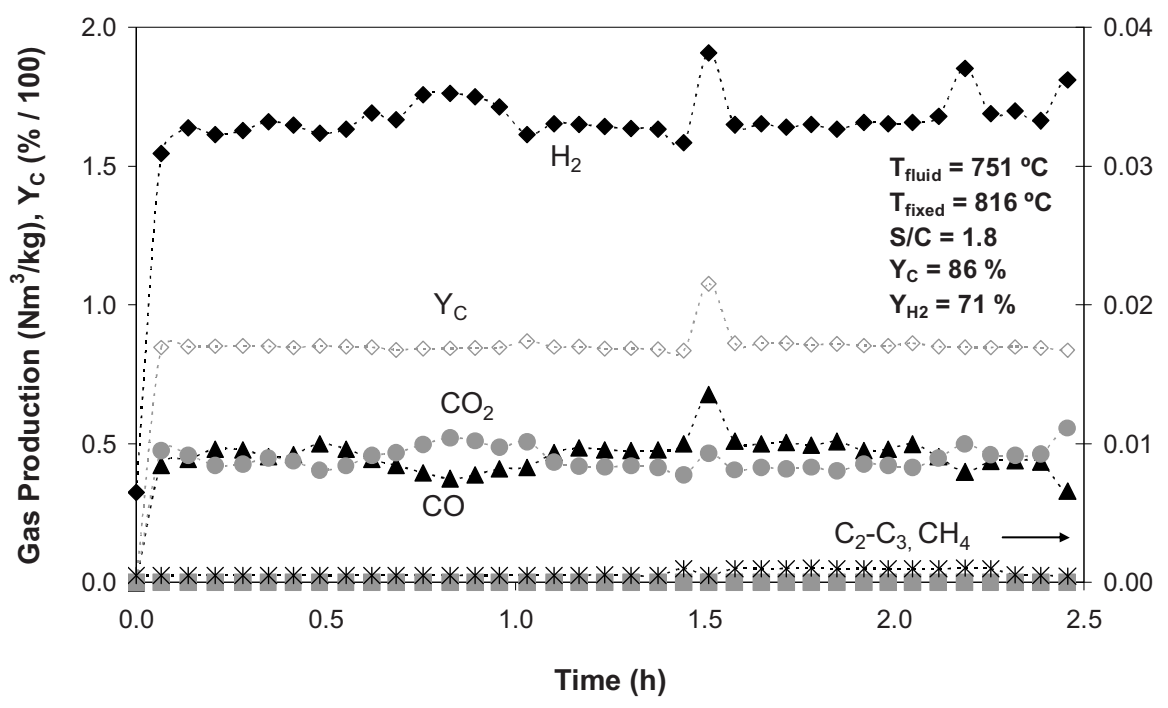

(B)

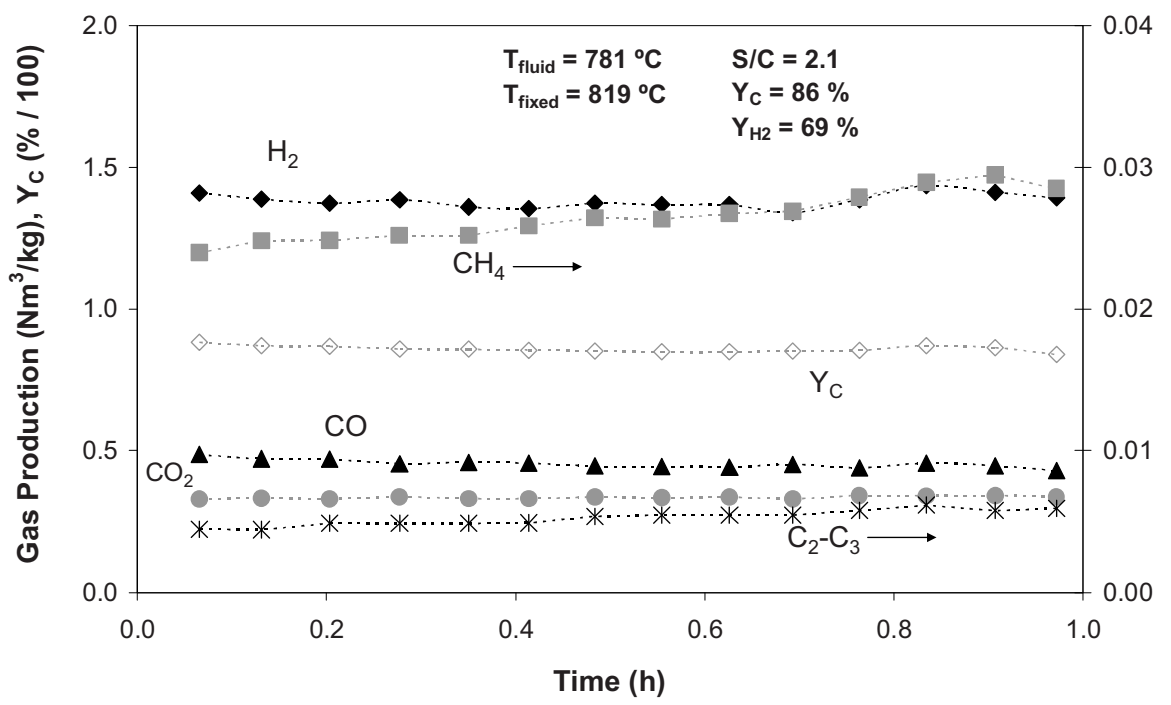

Figure 3.2. Gas production versus time for typical runs with both reactors at $\sim 800{ }^{\circ} \mathrm{C}$ and $\mathrm{S} / \mathrm{C} \approx 2$, (A) using $5 \mathrm{~kg}$ of K46, and (B) using $2.5 \mathrm{~kg}$ of K46 catalyst. 


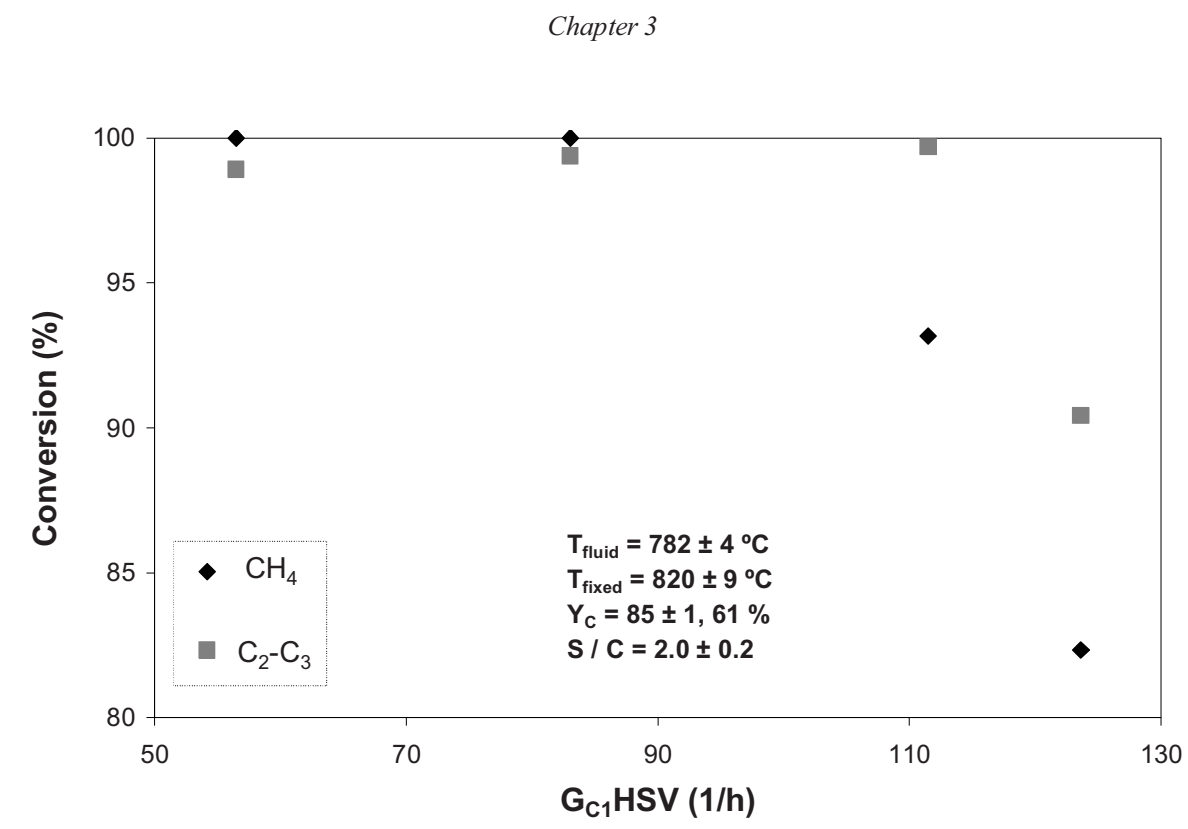

Figure 3.3. Methane conversion and $\mathrm{C}_{2}-\mathrm{C}_{3}$ conversion versus the space velocity $\left(\mathrm{G}_{\mathrm{C} 1} \mathrm{HSV}\right)$.

The amounts of catalysts used were 7.5, 5.0, 4.7, and $2.5 \mathrm{~kg}$, respectively.

The contact times were 1.9, 2.4, 2.1, and $1.4 \mathrm{~s}$.

When using $2.5 \mathrm{~kg}$ of catalyst, slight catalyst deactivation is observed showing an increased production of $\mathrm{CH}_{4}$ and $\mathrm{C}_{2}-\mathrm{C}_{3}$ in time (see Figure 3.2B). This may be caused by contacting between catalyst and sand and/or carbonaceous particles.

Deactivation during a run has never been observed when using $5 \mathrm{~kg}$ or more catalyst (see Figure 3.2A for an example). The carbon to gas conversion is not influenced by the amount of catalyst used (e.g. compare Figure $3.2 \mathrm{~A}$ and B), which means that no additional/significant amounts of carbon in the form of coke is retained in the fixed bed and gasified when the amount of catalyst is increased.

Table 3.2 shows a series of experiments with similar conditions using $5.0 \mathrm{~kg}$ of catalyst. At the end of the experiments, the formed carbonaceous deposits were gasified using steam or steam/air, and the catalyst was reduced with hydrogen at the start of the next experiment. It has appeared that the variations in fluid and fixed bed temperature and other process parameters (like $\mathrm{S} / \mathrm{C}$ ratio) reported in Table 3.2 did not result in significant differences in the carbon to gas conversion and the gas produced under otherwise identical conditions (see section 3.3.2). As can be seen from Table 3.2, the carbon to gas 
conversion and the amount of gases produced and its composition are not affected by the number of times the catalyst was used. This means that the catalyst is stable through several reactivation cycles and that experiments can be done in a reproducible manner in the setup. However, long duration testing ( $>$ days) is required to analyze the stability of the catalyst under the fouling (coke) and poisoning (e.g. S) conditions of pyrolysis oilderived gases and vapors for commercially expected life times. Tests with crushed catalysts and/or operating under elevated pressures are required to evaluate the actual reactivity under commercial conditions.

Table 3.2. Series of experiments with similar conditions using $5 \mathrm{~kg}$ of K46 and the same batch of pyrolysis oil. ${ }^{\mathrm{a}}$

\begin{tabular}{|cccc|}
\hline Run & 1 & 6 & 9 \\
Feed type & pine & pine & pine \\
Liquid feed $(\mathrm{kg} / \mathrm{h})$ & 0.44 & 0.58 & 0.62 \\
Bed Type: sand $(\mathrm{kg})$ & 5.1 & 5.1 & 5.1 \\
: inert $(\mathrm{kg})$ & 3.6 & 3.6 & 3.6 \\
: K46 $(\mathrm{kg})$ & 5.0 & 5.0 & 5.0 \\
: K23 $(\mathrm{kg})$ & 0.0 & 0.0 & 0.0 \\
$\mathrm{~T}$ fluid bed $\left({ }^{\circ} \mathrm{C}\right)$ & 652 & 598 & 788 \\
$\mathrm{~T}$ fixed bed $\left({ }^{\circ} \mathrm{C}\right)$ & 777 & 754 & 828 \\
$\mathrm{~S} / \mathrm{C}$ & 2.7 & 2.4 & 2.2 \\
$\mathrm{Carbon} \mathrm{to} \mathrm{Gas}(\%)$ & 67 & 63 & 61 \\
$\mathrm{H}_{2}$ yield $(\%)$ & 60 & 58 & 58 \\
& \multicolumn{6}{c}{$\mathrm{Gas}$ Production $\left(\mathrm{Nm}{ }^{3} / \mathrm{kg}\right)$} \\
$\mathrm{H}_{2}$ & 1.29 & 1.16 & 1.16 \\
$\mathrm{CH}_{4}$ & 0.00 & 0.00 & 0.00 \\
$\mathrm{CO}$ & 0.28 & 0.27 & 0.25 \\
$\mathrm{CO}_{2}$ & 0.39 & 0.34 & 0.33 \\
$\mathrm{C}_{2}-\mathrm{C}_{3}$ & 0.00 & 0.00 & 0.00 \\
& Gas composition $\left(\mathrm{vol} \%, \mathrm{~N}_{2}\right.$ free $)$ \\
$\mathrm{H}_{2}$ & 64.6 & 63.5 & 62.7 \\
$\mathrm{CH}_{4}$ & 0.0 & 0.1 & 0.0 \\
$\mathrm{CO}_{\mathrm{CO}_{2}}$ & 14.0 & 14.9 & 13.7 \\
$\mathrm{C}_{2}-\mathrm{C}_{3}$ & 19.5 & 18.4 & 18.0 \\
& 0.0 & 0.0 & 0.0 \\
\hline
\end{tabular}

${ }^{\mathrm{a}}$ The run number indicates the number of times the same catalyst has been used. Runs in between were done at different operating conditions.

With both reactors at $\sim 800{ }^{\circ} \mathrm{C}$, the total carbon recovery found in the two stage system varies between $75 \%$ and $99 \%$ with the majority between $80 \%$ and $90 \%$. The 
carbon from the pyrolysis oil is distributed over (i) permanent gases, (ii) tars, and (iii) carbonaceous particles/deposits. Here, three different tars are considered: primary, secondary, and tertiary. Primary tars are defined as oxygenates as produced in fast pyrolysis $\left(\sim 500{ }^{\circ} \mathrm{C}\right)$ of biomass. Secondary (single and double rings) and tertiary (multiple rings) tars are the result of cracking and recombination reactions resulting in oxygen free (or lean) mono- and multicyclic carbon rings. Under the reactor conditions applied in this work, the tars appear as vapors and/or aerosols.

Carbonaceous particles can be deposited on the fluidized or fixed bed (coke) or are entrained from the setup as particulates/xenospheres. Because the entrained particles could not be well quantified and only a few tar analyses were done, no complete carbon closure could be given. The full measurement of the carbon distribution of pyrolysis oil atomization over the products (gas, vapors and carbonaceous deposits) has been measured in a dedicated gasification setup and is presented in Chapter 4 .

\subsection{2 $T_{\text {fluidized bed }} \geq 630^{\circ} \mathrm{C}, 670^{\circ} \mathrm{C} \geq T_{\text {fixed bed }} \geq 830^{\circ} \mathrm{C}$}

In Chapter 2, it has been shown from studies on the inert fluidized bed separately that above $630{ }^{\circ} \mathrm{C}$ fluidized bed temperature, (i) the permanent gas production (on carbon basis) does not increase with the temperature any further, and (ii) the $\mathrm{CH}_{4}$ yield is constant. Typically $65-80 \%$ of the carbon in the feed is transferred to permanent gas under these conditions. The gas composition resembles a fuel gas: $\mathrm{CO}, \mathrm{CO}_{2}, \mathrm{CH}_{4}, \mathrm{C}_{\mathrm{n}} \mathrm{H}_{\mathrm{m}}$, $\mathrm{H}_{2}, \mathrm{H}_{2} \mathrm{O}$, and secondary/tertiary tars.

In analogy with gasification of solid biomass [7], it might be concluded that at fluidized bed temperatures higher than $630{ }^{\circ} \mathrm{C}$ primary tars are (nearly) fully converted to secondary/tertiary tars and permanent gases. Hence, thermal cracking reactions play an important role in transforming the primary tars to gases including hydrocarbons.

For the two stage system, these observations lead to the supposition that with the fluidized temperature above $630{ }^{\circ} \mathrm{C}$, the primary role of the catalytic fixed bed is to modify the gas composition by enhancing hydrocarbon steam/dry reforming and the water gas shift.

In Figure 3.4, gas production in the two stage system operating at maximum gas production (on carbon basis) in the inert fluidized bed $\left(\mathrm{T}_{\text {fluidized }} \geq 630{ }^{\circ} \mathrm{C}\right.$ ) is shown. Hydrocarbon production level in the inert fluidized bed and equilibrium predictions are 
also indicated in this Figure. The temperature of the catalytic fixed bed is varied in the range of $671-826{ }^{\circ} \mathrm{C}$. Figure 3.4 shows that, when hydrocarbons are produced at significant levels in the fluidized bed $\left(\mathrm{T}>630^{\circ} \mathrm{C}\right)$, a fixed bed temperature of $800{ }^{\circ} \mathrm{C}$ or higher is required to achieve full conversion of these hydrocarbons. However, operating the fixed bed at $740{ }^{\circ} \mathrm{C}$ results already in nearly (vol\%) hydrocarbon free gas.

(A)

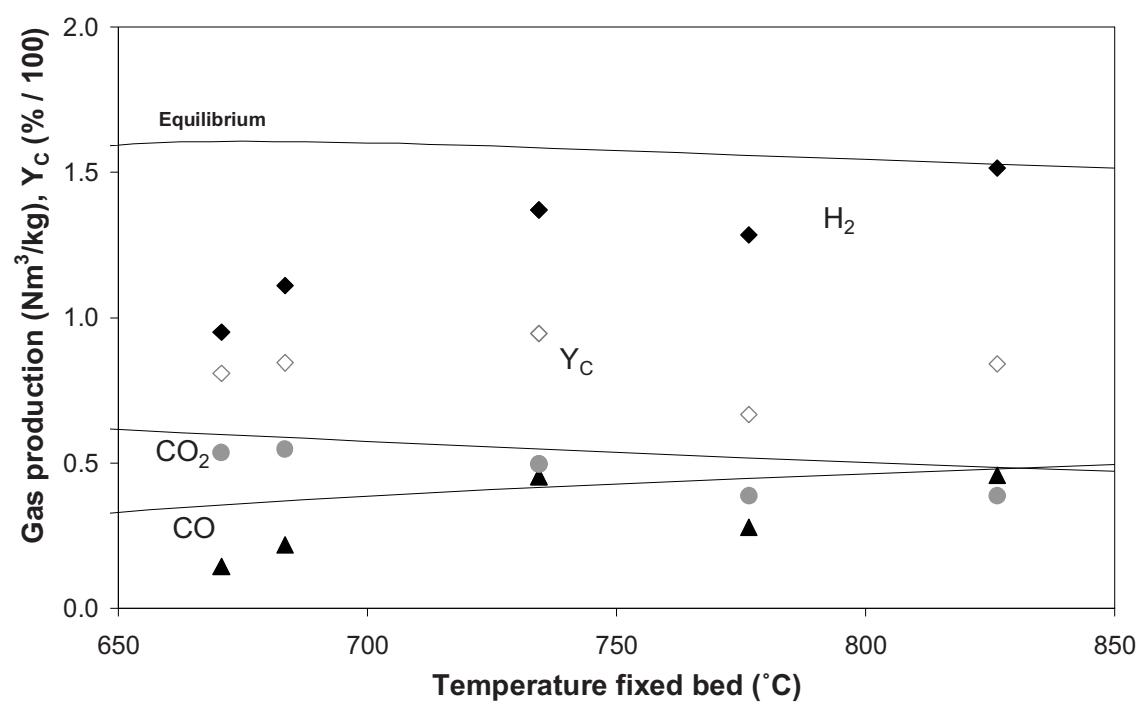


(B)

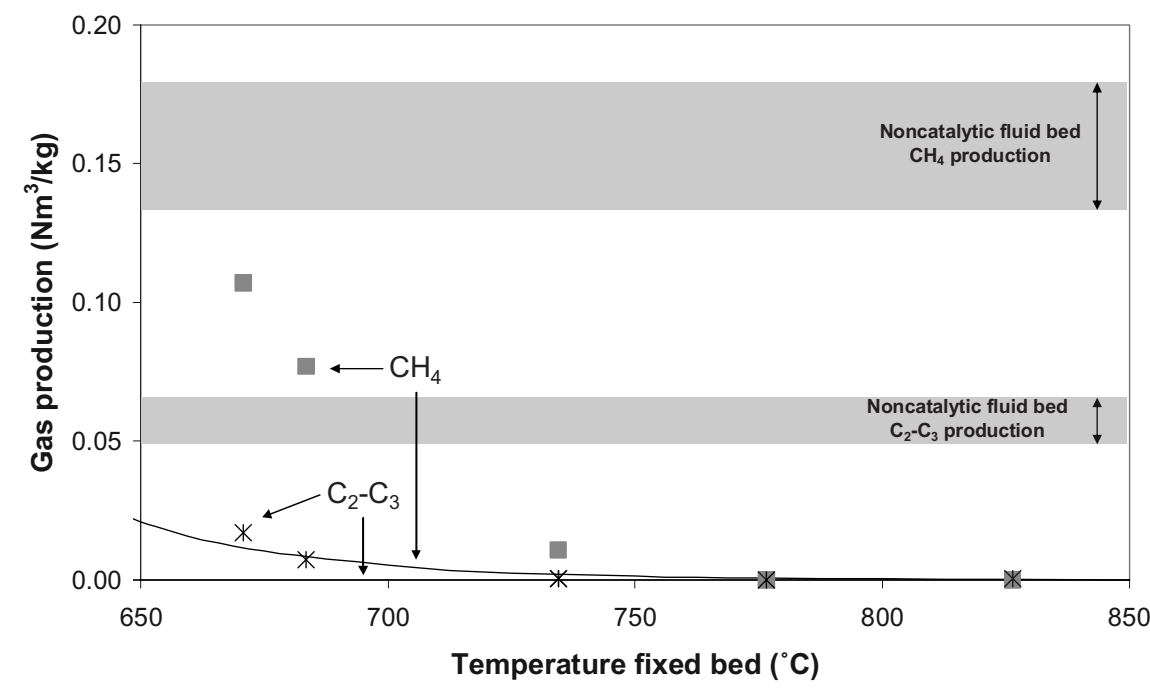

Figure 3.4. Gas production versus fixed bed temperature where the fluidized bed was above $630^{\circ} \mathrm{C}\left(632-796^{\circ} \mathrm{C}\right)$ with a steam over carbon ratio of $2.4 \pm 0.1$. The lines in the Figure are the equilibrium gas compositions calculated on input basis. Part (A) shows the $\mathrm{H}_{2}, \mathrm{CO}$, and $\mathrm{CO}_{2}$ production and carbon to gas conversion, and part (B) shows the $\mathrm{CH}_{4}$ and $\mathrm{C}_{2}-\mathrm{C}_{3}$ production where the noncatalytic fluid bed gas production from Chapter 2 is indicated as gray area.

By comparing the two stage reactor results with equilibrium predictions, it becomes clear that the catalytic fixed bed reaches equilibrium at a typical methane reforming temperature of $800{ }^{\circ} \mathrm{C}$. Below $800{ }^{\circ} \mathrm{C}$, equilibrium is not reached, which can be attributed to incomplete carbon to gas conversion over the staged system and/or incomplete hydrocarbon conversion over the catalytic bed.

\subsection{3 $430{ }^{\circ} \mathrm{C} \geq T_{\text {fluidized bed }} \geq 500^{\circ} \mathrm{C}, 530{ }^{\circ} \mathrm{C} \geq T_{\text {fixed bed }} \geq 690^{\circ} \mathrm{C}$}

Atomization of the oil in a fluidized bed at $430-500{ }^{\circ} \mathrm{C}$ results in only a small amount of permanent gas via pyrolysis, below $25 \%$ on carbon basis [11]. In the atomization process, a part of the oil remains as a solid residue. Figure 3.5 shows results of TGA tests showing that ca. $25 \%$ of the carbon of the oil remains as a carbonaceous residue (char) and weight loss hardly proceeds above $500{ }^{\circ} \mathrm{C}$. Combination of the $25 \%$ (carbon basis) 
permanent gas and $25 \%$ carbon to char leads to the conclusion that at $500{ }^{\circ} \mathrm{C}$ ca. $50 \%$ of the carbon in the oil is transferred to the vapor phase. This process might be called vaporization, although it is sure that this is not the only process going on. However, when the fluidized bed temperature is as low as $500{ }^{\circ} \mathrm{C}$, thermal cracking of the pyrolysis oil is minimized, yielding a vapor that contains mostly oxygenated compounds, that is, primary tars.

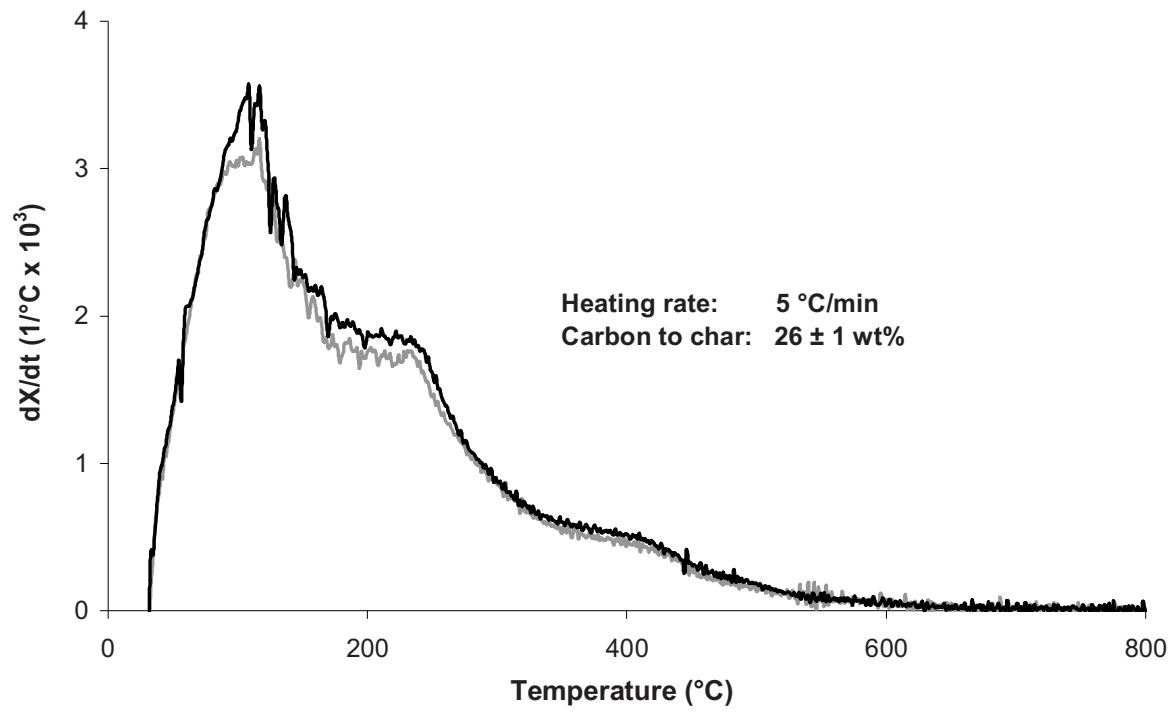

Figure 3.5. TGA of pine pyrolysis oil. Two identical runs are plotted.

For the staged concept, it is expected that when operating the inert fluid bed at ca. $500{ }^{\circ} \mathrm{C}$ and the fixed bed at a higher temperature, the primary tars are reformed in the catalytic fixed bed. Because of the higher reforming reactivity of pyrolysis vapors as compared to hydrocarbons, their catalytic reforming temperature might be lower. To study the limits of the system, the catalyst bed temperature was lowered well below commercial operation conditions. Figure 3.6 shows results (total carbon recovery and carbon to gas conversion) of experiments with the fluidized bed operating at low temperature $\left(<500{ }^{\circ} \mathrm{C}\right)$, while the temperature of the fixed catalytic bed increases from 533 to $690{ }^{\circ} \mathrm{C}$. These are compared to results of only the inert fluidized bed and results of 
the two stage system with $\mathrm{T}_{\text {fluid }}>650{ }^{\circ} \mathrm{C}$ and $\mathrm{T}_{\text {fixed }}>740{ }^{\circ} \mathrm{C}$. The same oil batch was used in all experiments. Figure 3.6 shows that at a catalytic fixed bed temperature of $533{ }^{\circ} \mathrm{C}$ not much of the primary tars are converted to permanent gases. This follows from the observation that the carbon to gas conversion of the inert fluidized bed only at $530{ }^{\circ} \mathrm{C}$ is similar to the carbon to gas conversion of the staged system with $\mathrm{T}_{\text {fluidized bed }}=432{ }^{\circ} \mathrm{C}$ and $\mathrm{T}_{\text {fixed bed }}=533{ }^{\circ} \mathrm{C}(27 \%$ noncatalytic and $35 \%$ staged carbon to gas conversion $)$. However, the total carbon recovery (after burnoff) is for these conditions at a level of $75 \%$, which shows that the primary tars lead to severe coking on the catalyst. Increasing the temperature of the fixed catalytic bed clearly results in more gas production through reforming reactions of the primary tars and less coke depositing on the catalyst.

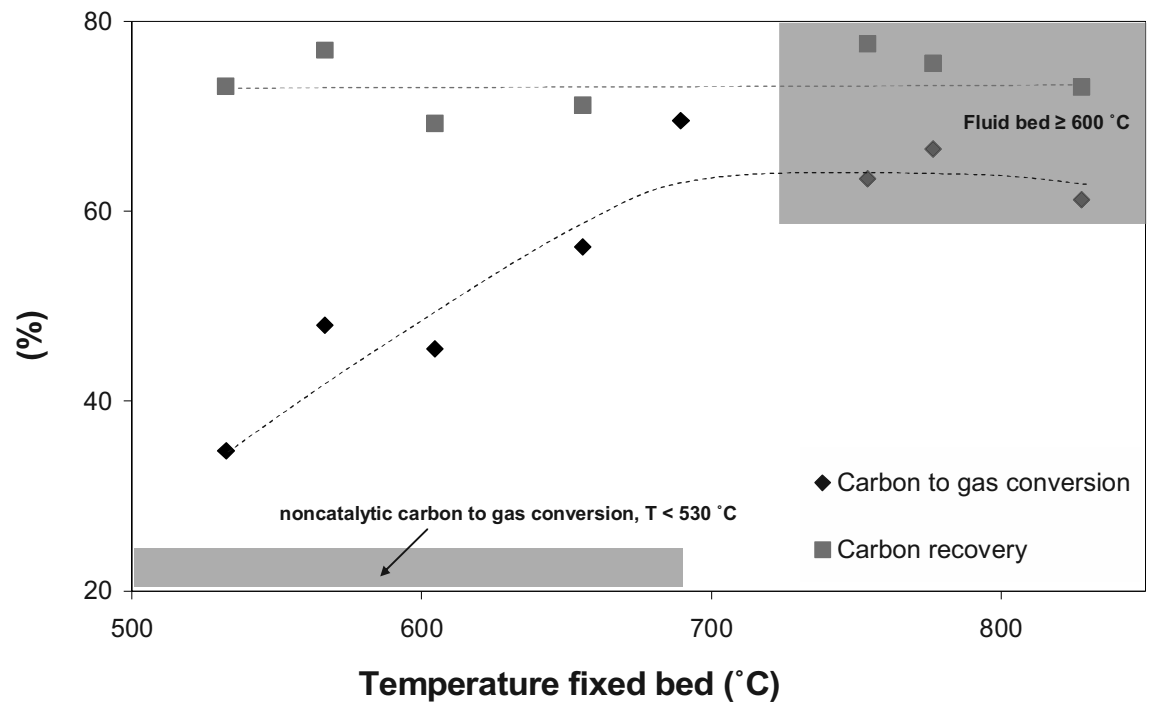

Figure 3.6. Carbon to gas conversion and total carbon recovery versus fixed bed temperature where the fluidized bed was below $500{ }^{\circ} \mathrm{C}\left(432-500^{\circ} \mathrm{C}\right)$ with a steam over carbon ratio of $2.6 \pm 0.1$. The noncatalytic fluid bed carbon to gas conversion below $530{ }^{\circ} \mathrm{C}$ from Chapter 2 is indicated as a reference. The higher three points (marked by the gray area in the right top) are at a fluid bed temperature $\geq 600^{\circ} \mathrm{C}$ and are added to the graph for a complete overview. Detailed results of the four highest fixed bed temperatures are given in Tables 3.2 and 3.3. 
Table 3.3 shows two gasification runs, which are also presented in Figure 3.6, where the temperature settings of the staged system were different. Surprisingly, with the atomizer (fluidized bed) at $496{ }^{\circ} \mathrm{C}$ and the catalytic fixed bed at $690{ }^{\circ} \mathrm{C}$, the performance is nearly equal with respect to carbon to gas conversion and syngas production as when operating both reactors at ca. $800{ }^{\circ} \mathrm{C}$. The only major difference is that the hydrocarbons are not fully converted at $700{ }^{\circ} \mathrm{C}$. Apparently, the majority in the fluidized bed produced vapors (primary tars) can be reformed by the catalytic bed to gases under these conditions.

Table 3.3. Gasification results done at different temperatures of the staged system

\begin{tabular}{|ccc|}
\hline Feed type & pine & pine \\
Liquid feed $(\mathrm{kg} / \mathrm{h})$ & 0.51 & 0.62 \\
Bed Type: sand $(\mathrm{kg})$ & 5.0 & 5.0 \\
$:$ inert $(\mathrm{kg})$ & 3.6 & 3.6 \\
$: \mathrm{K} 46(\mathrm{~kg})$ & 5.0 & 5.0 \\
$: \mathrm{K} 23(\mathrm{~kg})$ & 0.0 & 0.0 \\
T fluid bed $\left({ }^{\circ} \mathrm{C}\right)$ & 496 & 788 \\
T fixed bed $\left({ }^{\circ} \mathrm{C}\right)$ & 690 & 828 \\
$\mathrm{~S} / \mathrm{C}$ & 2.6 & 2.2 \\
Carbon to Gas $(\%)$ & 70 & 61 \\
$\mathrm{H}_{2}$ yield $(\%)$ & 64 & 58 \\
& Gas Production $\left(\mathrm{Nm}^{3} / \mathrm{kg}\right)$ \\
$\mathrm{H}_{2}$ & 1.28 & 1.16 \\
$\mathrm{CH}_{4}$ & 0.00 & 0.00 \\
$\mathrm{CO}^{2}$ & 0.28 & 0.25 \\
$\mathrm{CO}_{2}$ & 0.39 & 0.33 \\
$\mathrm{C}_{2}-\mathrm{C}_{3}$ & 0.00 & 0.00 \\
& Gas composition $\left(\mathrm{vol} \%, \mathrm{~N}_{2}\right.$ free $)$ \\
$\mathrm{H}_{2}$ & 63.8 & 62.7 \\
$\mathrm{CH}_{4}$ & 0.1 & 0.0 \\
$\mathrm{CO}$ & 14.0 & 13.7 \\
$\mathrm{CO}_{2}$ & 19.3 & 18.0 \\
$\mathrm{C}_{2}-\mathrm{C}_{3}$ & 0.0 & 0.0 \\
\hline & &
\end{tabular}

At $\mathrm{T}_{\text {fluidized bed }}=496{ }^{\circ} \mathrm{C}$ and $\mathrm{T}_{\text {fixed bed }}=690{ }^{\circ} \mathrm{C}$, the methane levels are relatively low $(0.1 \mathrm{vol} \%)$. These low amounts of methane and no $\mathrm{C}_{2}-\mathrm{C}_{3}$ present are related to the low amounts being produced in the fluidized bed at $496{ }^{\circ} \mathrm{C}$. At higher fluid bed temperatures, a fuel gas is produced in the fluid bed, which contains more methane that is hardly converted by the catalyst at the employed temperature of the fixed bed of $690{ }^{\circ} \mathrm{C}$ [9]. 
The observation that the carbon recovery is constant while varying the fluidized bed temperature in the range of $432-788{ }^{\circ} \mathrm{C}$ and the catalytic fixed bed temperature in the range of $533-828{ }^{\circ} \mathrm{C}$ (see Figure 3.6) suggests that for these conditions the amount of pyrolysis oil that is converted to permanent gases (cracking in fluid bed and catalytic steam reforming in fixed bed) and deposits (char residue in fluid bed and coke on catalyst in fixed bed) is constant. The TGA results showing that the evaporation process is almost finished at ca. $500{ }^{\circ} \mathrm{C}$ already support this hypothesis. More results on this topic will be presented in Chapter 4.

Additional tests have been performed on a side stream of a commercial twin retort charcoal production plant (see Appendix I). A fraction of the gas/vapor stream $\left(500{ }^{\circ} \mathrm{C}\right.$, $70 \mathrm{wt} \%$ vapor, $30 \mathrm{wt} \%$ gas) from the retort was led over a catalytic bed of $7.5 \mathrm{~kg}$ at $850{ }^{\circ} \mathrm{C}$. It has been found in consecutive runs of several hours that this stream can be converted in synthesis gas $\left(\mathrm{H}_{2} / \mathrm{CO} \sim 1.2\right)$ with only a very low amount of methane $(<0.5 \mathrm{vol} \%)$. The low $\mathrm{H}_{2} / \mathrm{CO}$ ratio is in this case caused by the lack of steam in the feed.

\subsection{4 $\mathrm{H}_{2} / \mathrm{CO}$ Ratio}

The $\mathrm{H}_{2} / \mathrm{CO}$ ratio is a very important quality indicator of the produced syngas, because downstream conversion processes of syngas to products like alcohols and FischerTropsch fuels require narrow input $\mathrm{H}_{2} / \mathrm{CO}$ ratios for optimal performance. Obviously, the closer the $\mathrm{H}_{2} / \mathrm{CO}$ ratio of the syngas from the gas producer (e.g. reformer, gasifier) meets the requirement of the secondary conversion unit, the better.

Figure 3.7 shows the observed effect of (A) catalytic fixed bed temperature and (B) steam over carbon ratio on the $\mathrm{H}_{2} / \mathrm{CO}$ ratio. In this Figure also predictions from equilibrium models are plotted for comparison with the experimental data.

The calculated temperature dependence of the $\mathrm{H}_{2} / \mathrm{CO}$ ratio is, as expected, high at low temperatures and low at higher temperatures. The experimentally obtained $\mathrm{H}_{2} / \mathrm{CO}$ ratios fit well between the two equilibrium calculations, which indicates that (i) the catalyst has a water gas shift activity over the whole temperature range measured despite coking of the catalyst, and (ii) the two ways of calculating the equilibrium are two extremes that capture the actual process. 
(A)

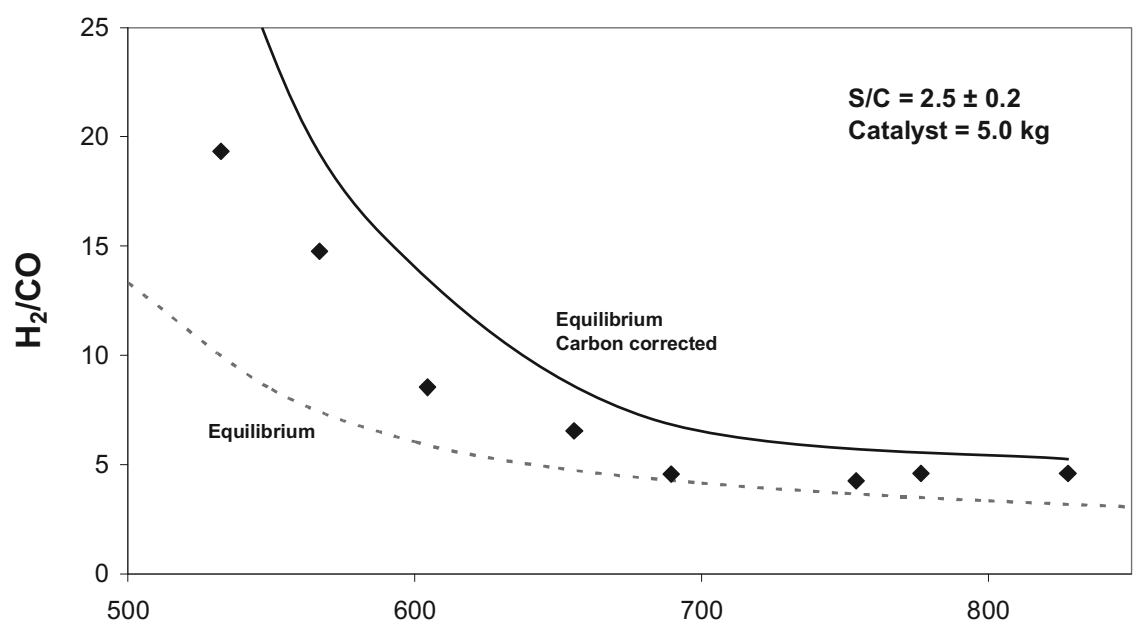

Temperature fixed bed ( $\left.{ }^{\circ} \mathrm{C}\right)$

(B)

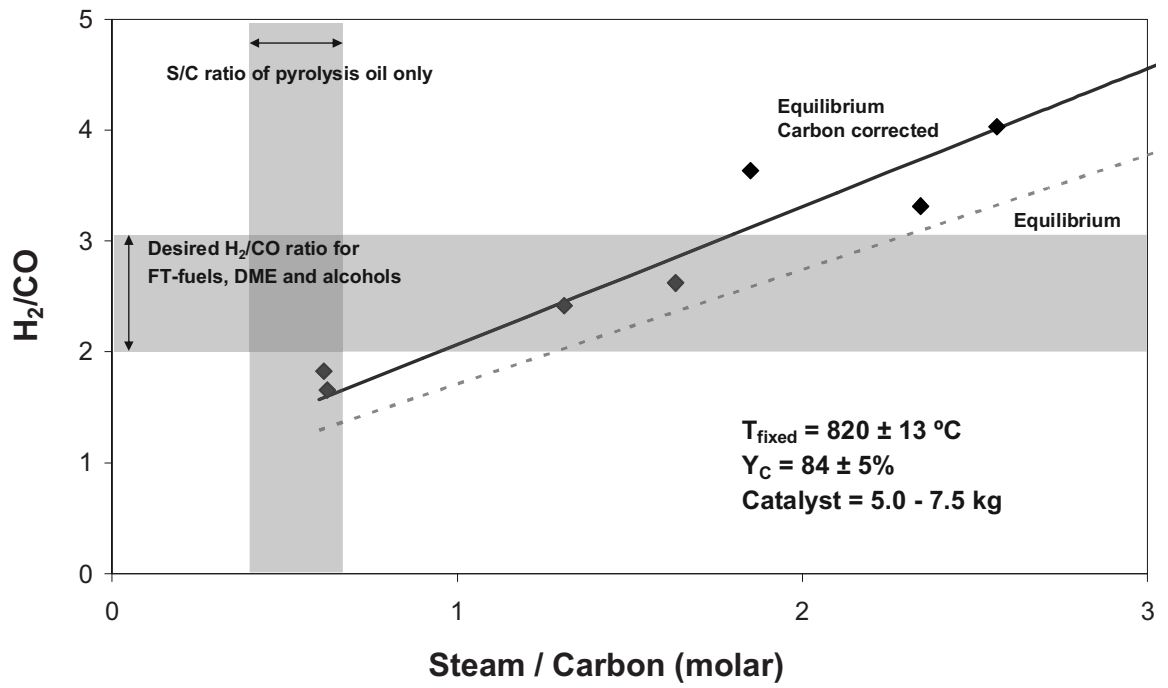

Figure 3.7. (A) Hydrogen over carbon monoxide ratio versus catalytic fixed bed temperature. (B) Hydrogen over carbon monoxide ratio versus steam over carbon ratio. The fixed bed temperature is kept constant, while the amount of catalyst, fluid bed temperature, and batch/type of pyrolysis oil are varied. The ranges of steam/carbon ratios of pure pyrolysis oils and desired $\mathrm{H}_{2} / \mathrm{CO}$ ratios are indicated by the gray areas. Both equilibrium (gray dotted) and carbon corrected equilibrium (black line) values are given in the Figure. 
In methane steam reforming, the steam over carbon $(\mathrm{S} / \mathrm{C})$ ratio is, besides a steering parameter for the gas composition, also of importance for coke on catalyst formation. Higher S/C ratios than needed for stoichiometry are applied to minimize coke on catalyst.

Because pyrolysis oil as compared to methane and naphtha steam reforming already contains water and high amounts of molecular-bonded oxygen, it is worthwhile to see the impact of the steam over carbon ratio. At $\mathrm{T}_{\text {fixed bed }} \approx 820{ }^{\circ} \mathrm{C}$, the $\mathrm{H}_{2} / \mathrm{CO}$ has, as expected when the water gas shift reaction readily occurs, a strong dependence on the steam over carbon ratio (see Figure 3.7B). At a low steam over carbon ratio, the $\mathrm{H}_{2} / \mathrm{CO}$ is low, and it steadily increases with increasing steam over carbon ratio. This is also predicted by equilibrium calculations.

When operating the catalytic fixed bed at ca. $800{ }^{\circ} \mathrm{C}$, the water, which is part of the pyrolysis oil, is almost sufficient $\left(\mathrm{H}_{2} / \mathrm{CO}\right.$ ratio of $\left.\sim 1.8\right)$ to reach the desired $\mathrm{H}_{2} / \mathrm{CO}$ ratios $(\sim 2-3)$ for the production of FT-fuels, DME, and alcohols. To actually attain the desired $\mathrm{H}_{2} / \mathrm{CO}$ ratios, a small amount of steam has to be added directly to the staged reactor, which is also probably necessary to suppress coke formation on the catalyst.

\subsubsection{Variation of Feed}

Table 3.4 shows gasification results at similar temperatures for two different types of pyrolysis oil (pine and beech) and of another liquid biomass stream, a 'light' and a 'heavy' sugar waste stream. The variation of pyrolysis oil origin (beech and pine) does not result in very different gasification behavior for these particular runs. However, when different batches of pyrolysis oil are being used, differences in gasification behavior are observed, which is then mainly expressed in the carbon to gas conversion (compare pine oil in Table 3.2 to pine oil in Table 3.4; different pine pyrolysis oil batches were used). Each produced pyrolysis oil seems to have its own gasification characteristics, which makes it important to do each experimental series with the same batch of oil. The mechanism behind this is not yet clear, but it is necessary to examine the evaporation/gasification behavior of each pyrolysis oil batch in, for instance, a standard TGA experiment.

The sugar waste streams that were gasified are a side product from lactic acid production. As compared to pyrolysis oil, they are rich in ash $(\sim 2-3 \mathrm{wt} \%)$ and have a low water content. Because of the high viscosity of the heavy sugar waste stream, it had to be 
diluted with water before atomization. Both streams were readily gasified with carbon to gas conversions comparable to pyrolysis oil gasification. However, the methane content of the produced gases was higher. This is probably caused by the high amount of compounds, which are difficult/impossible to evaporate (like glucose and its polymers) and are thermally cracked, yielding, among others, methane.

Table 3.4. Gasification results of different pyrolysis oil and sugar waste streams

\begin{tabular}{|c|c|c|c|c|}
\hline Feed type & beech & pine & \multicolumn{2}{|c|}{ 'Light' sugar 'Heavy' sugar } \\
\hline Liquid feed $(\mathrm{kg} / \mathrm{h})$ & 0.56 & 0.43 & 0.43 & 0.80 \\
\hline Bed Type: sand (kg) & 5.0 & 5.0 & 5.0 & 5.0 \\
\hline : inert $(\mathrm{kg})$ & 0.0 & 0.0 & 3.7 & 3.7 \\
\hline : K46 (kg) & 5.0 & 5.0 & 4.7 & 4.7 \\
\hline : K23 (kg) & 2.5 & 2.5 & 0.0 & 0.0 \\
\hline T fluid bed $\left({ }^{\circ} \mathrm{C}\right)$ & 780 & 805 & 681 & 648 \\
\hline $\mathrm{T}$ fixed bed $\left({ }^{\circ} \mathrm{C}\right)$ & 808 & 815 & 795 & 787 \\
\hline $\mathrm{S} / \mathrm{C}$ & 1.6 & 1.6 & 0.6 & 2.3 \\
\hline Carbon to Gas (\%) & 89 & 88 & 89 & 86 \\
\hline \multirow[t]{2}{*}{$\mathrm{H}_{2}$ yield $(\%)$} & 67 & 68 & 50 & 44 \\
\hline & \multicolumn{4}{|c|}{ Gas Production $\left(\mathrm{Nm}^{3} / \mathrm{kg}\right)$} \\
\hline $\mathrm{H}_{2}$ & 1.53 & 1.56 & 0.77 & 0.72 \\
\hline $\mathrm{CH}_{4}$ & 0.00 & 0.00 & 0.03 & 0.10 \\
\hline $\mathrm{CO}$ & 0.58 & 0.60 & 0.48 & 0.19 \\
\hline $\mathrm{CO}_{2}$ & 0.35 & 0.30 & 0.18 & 0.36 \\
\hline \multirow[t]{2}{*}{$\mathrm{C}_{2}-\mathrm{C}_{3}$} & 0.00 & 0.00 & 0.00 & 0.00 \\
\hline & \multicolumn{4}{|c|}{ Gas composition (vol\%, $\mathrm{N}_{2}$ free) } \\
\hline $\mathrm{H}_{2}$ & 61.1 & 62.6 & 50.3 & 51.5 \\
\hline $\mathrm{CH}_{4}$ & 0.0 & 0.0 & 2.2 & 7.4 \\
\hline $\mathrm{CO}$ & 23.3 & 23.9 & 30.4 & 13.3 \\
\hline $\mathrm{CO}_{2}$ & 13.9 & 11.9 & 11.6 & 25.5 \\
\hline $\mathrm{C}_{2}-\mathrm{C}_{3}$ & 0.0 & 0.0 & 0.1 & 0.2 \\
\hline
\end{tabular}

\subsection{Model}

A model has been developed in which operating conditions and modes can be varied of the gasification reactor concept to estimate the type of gas that is being produced (syngas and methane content and the $\mathrm{H}_{2} / \mathrm{CO}$ ratio) and to calculate the lower heating value (LHV) efficiency. The model considers three cases of generating heat, which is needed for the process: (I) addition of pyrolysis oil (or any different fuel) to a combustor, 
(II) combustion of 'pure' carbon, which originates from the evaporator, and (III) hot product gas combustion.

For (I) and (III), an assumption is made that the char that is formed in the evaporator can be gasified (with, for instance, $\mathrm{H}_{2} \mathrm{O}$ and $\mathrm{CO}_{2}$ ) without the use of oxygen. At the estimated employable temperature $\left(450-700{ }^{\circ} \mathrm{C}\right)$ of the evaporator, active support material is probably necessary to attain sufficient high char gasification rates (see also Chapter 5). Tests with $\mathrm{FeO}$ as a bed material have shown significant higher carbon to gas conversion as compared to sand [17]. Figure 3.8 shows the schematic overview of the modeled system, which can be summarized by the following:

- Feed: pyrolysis oil is defined with a LHV of $22 \mathrm{MJ} / \mathrm{kg}$ as $\mathrm{CH}_{1.67} \mathrm{O}_{0.67}$ on dry basis.

- Evaporator: it 'evaporates' the wet pyrolysis oil at $500{ }^{\circ} \mathrm{C}$ (pyrolysis oil + water $\rightarrow$ vapor + steam). When carbon combustion is considered (II), next to the evaporation a part of the oil is thermally cracked, yielding 'pure' carbon (and some water and hydrogen; $\mathrm{CH}_{1.67} \mathrm{O}_{0.67} \rightarrow \mathrm{C}+0.67 \mathrm{H}_{2} \mathrm{O}+0.165 \mathrm{H}_{2}$ ).

- Steam generation: an amount of steam is generated that together with the water of the pyrolysis oil is fed to the evaporator to set a desired steam over carbon ratio.

- Catalytic bed: chemical equilibrium is calculated at a given temperature.

- Combustor: feed fuel, carbon, or product gas is combusted at $100{ }^{\circ} \mathrm{C}$ higher than the catalytic bed using preheated air with a stoichiometry excess of 1.2.

- The heat of the product gas and exhaust gas can be partially (down to $200-250{ }^{\circ} \mathrm{C}$ ) used to supply heat for the process.

- The thermodynamic data of the gases and water/steam were taken from ref [18] using the ideal gas law.

The amount of fuel, carbon, or product gas that is being combusted is adjusted in such a way that the process is overall autothermal (e.g. heat duty reactors, stream heating/evaporation/cooling compensate each other, which is mathematically expressed by $\Sigma \mathrm{Q}-\mathrm{Q}_{\text {residual heat }}=0$ ). With an autothermal process, the LHV efficiency is simplified to:

$$
L H V_{\text {efficiency_total }}=100 \frac{L H V_{\text {syngas }+ \text { methane }}}{L H V_{\text {pyrolysis_oil }}}
$$


$L H V_{\text {efficiency_syngas }}=100 \frac{L H V_{\text {syngas }}}{L H V_{\text {pyrolysis_oil }}}$

The difference between the two efficiencies is the energy conserved in methane. In all of the cases, the heat requirement was at a lower temperature than the heat production so that in principle the process can be heat integrated, although in reality a 'working' heat exchange network and inevitable heat losses will lower the presented attained efficiencies. Because the gasification/steam reforming of pyrolysis oil will always be followed by an application of the produced gas and it can be used as an add-on process (for instance coreforming with natural gas), no attempt has been made to choose a heat integration network (including downstream conversion steps). Within the chosen boundaries of the model, no influence on the overall efficiency is seen by a set temperature of the fluidized and fixed bed or within the advantage of pressurizing the system (the gases are now produced at different pressures). The duty of the pressurization step of the gasifier is only marginal (duty of pumps of the pyrolysis oil and water), while the combustion is done at atmospheric pressure. In the case of carbon combustion, probably the combustion should also be done pressurized because solid circulation between the evaporator and combustor has to be enabled. No product gas upgrading has been included in the model because every application requires different upgrading specifications. The main inputs that were varied and evaluated outputs of the model are listed in Table 3.5. 


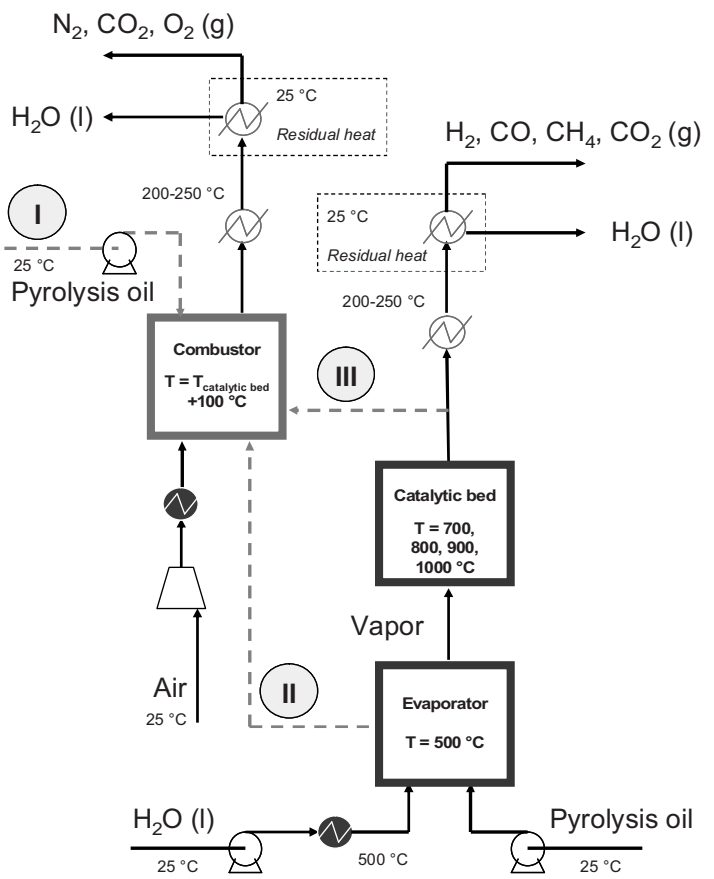

Figure 3.8. Schematic overview of the used model. Three methods were evaluated for supplying heat to the reactor: (I) combustion of external fuel (here pyrolysis oil), (II) combustion of produced carbon/char, and (III) combustion of part of the produced reformed gas.

Table 3.5. Main Inputs and Evaluated Outputs

\begin{tabular}{|cc|c|}
\hline INPUT (type) & Value & OUTPUT \\
\hline Temperature catalytic bed $\left({ }^{\circ} \mathrm{C}\right)$ & $700,800,900,1000$ & LHV efficiency syngas (\%) \\
Pressure gasifier (bar) & $1,15,30$ & LHV efficiency total (\%) \\
Steam / Carbon ratio (-) & $1,2,3,7$ & $\mathrm{H}_{2} /$ CO ratio (-) \\
Heat supply type & I, II, III & \\
\hline
\end{tabular}

Figure 3.9 shows the LHV efficiency to total gaseous products $\left(\mathrm{H}_{2}, \mathrm{CO}\right.$, and $\left.\mathrm{CH}_{4}\right)$ and to syngas and the $\mathrm{H}_{2} / \mathrm{CO}$ ratio at steam over carbon ratio for the three different ways of supplying heat to the system. The temperature $\left(800{ }^{\circ} \mathrm{C}\right)$ and pressure $(30$ bar) were chosen at normal commercial steam reforming operating conditions. 
(A)

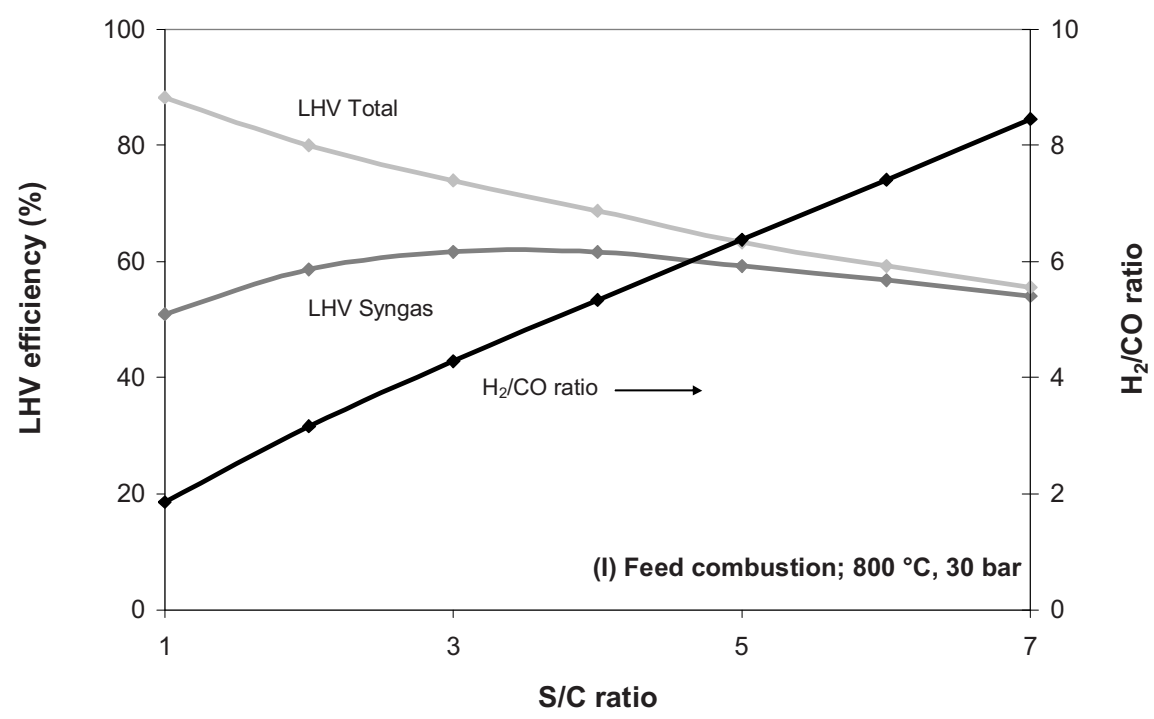

(B)

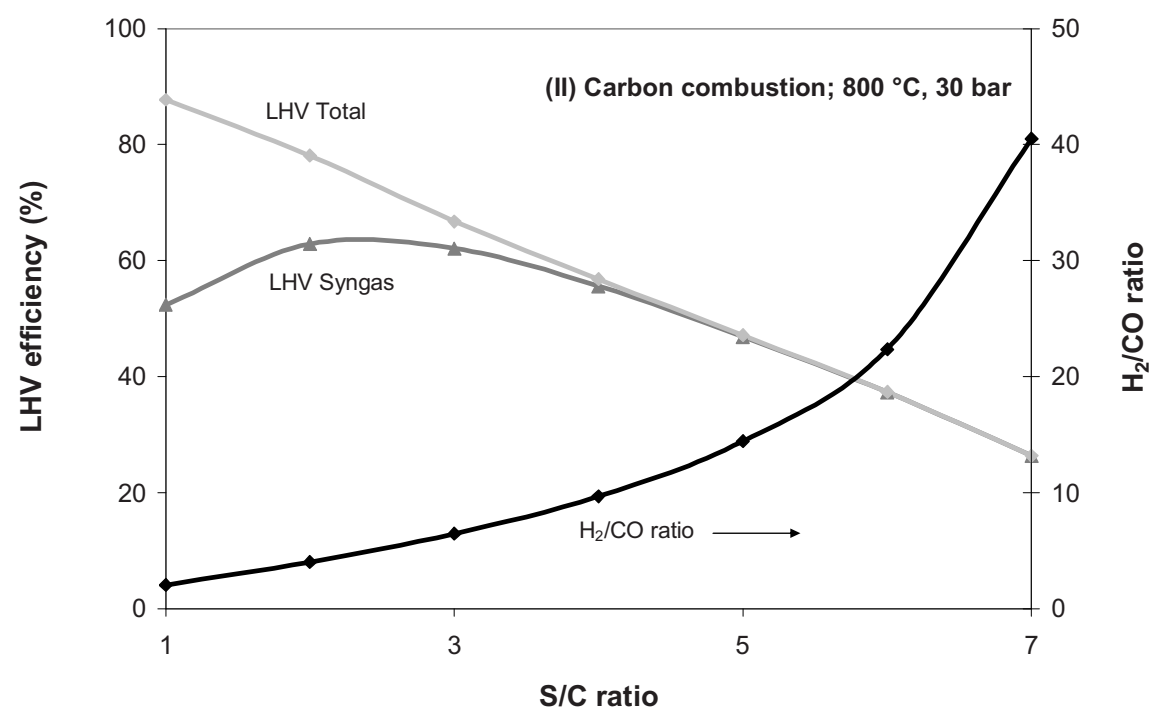


(C)

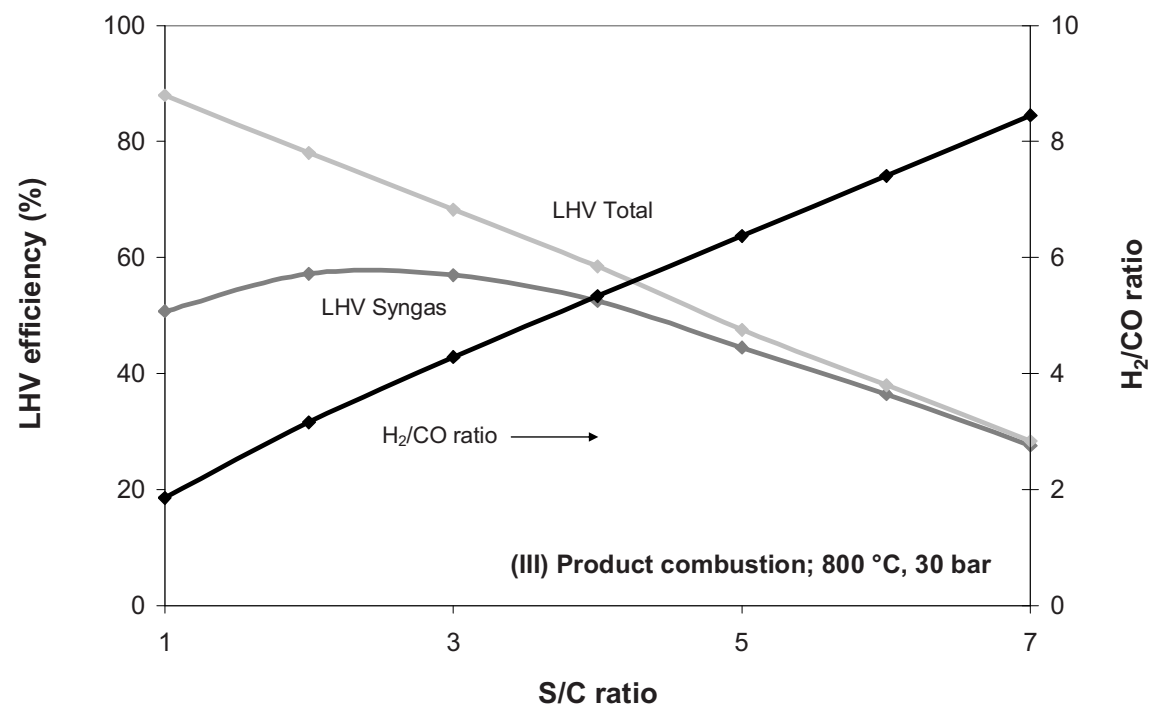

Figure 3.9. LHV efficiency (total and syngas) and the $\mathrm{H}_{2} / \mathrm{CO}$ ratio versus the steam over carbon ratio for (A) feed combustion, (B) carbon combustion, and (C) product gas combustion.

At an S/C of 1 , the three options of supplying heat do not have an impact on the evaluated outputs. The total LHV efficiency is high ( $\sim 88 \%)$ with an attractive $\mathrm{H}_{2} / \mathrm{CO}$ ratio $(\sim 2)$. However, the LHV efficiency to syngas is low $(\sim 51 \%)$, which will limit the application of fuel production (via Fischer-Tropsch) due to a low overall energy conversion. When the steam over carbon ratio is increased, the total LHV efficiency decreases rapidly, while the syngas LHV efficiency initially increases and then starts to approach the total LHV efficiency. The added steam to the system enables a higher methane conversion with the penalty of the high energy costs to produce the steam, which is mainly due to water evaporation. The three ways of heat production now also start to deviate from each other. External fuel combustion (I) shows the lowest total LHV efficiency loss because for the combustion of pyrolysis oil no additional steam is added. Carbon removal from the evaporator (II) enables in situ carbon rejection, which is especially interesting when hydrogen (or methane/hydrogen) production is envisaged because the removal of solid carbon reduces the amount of $\mathrm{CO}_{2}$ that has to be removed 
from the product gas downstream. The steam over carbon ratio limits are determined by attaining a desired $\mathrm{H}_{2} / \mathrm{CO}$ ratio and reaching a certain methane conversion, the amount of water that is present in the pyrolysis oil, the necessity of water to suppress coke formation and/or enhance its gasification, and additional energy cost to produce steam.

When high $\mathrm{S} / \mathrm{C}$ ratios are being used, the model resembles besides additional steam feeding to the whole pyrolysis oil also the conversion of the aqueous phase of pyrolysis oil because in the model it does not matter whether the steam heat duty is needed in a separate boiler or in the evaporator. Then operation mode I (Figure 3.9A) resembles aqueous phase reforming while using a different fuel in the combustor, and modes II (Figure 3.9B) and III (Figure 3.9C) resemble aqueous phase pyrolysis oil reforming and combustion for heat generation. What is clearly illustrated is that gasification/reforming of the aqueous fraction of pyrolysis oil (high $\mathrm{S} / \mathrm{C}$ ratio $>4$ ) is only able to produce hydrogen at a reasonable total LHV efficiency ( $\sim 55 \%$ with a $\mathrm{S} / \mathrm{C}$ ratio of 7 ; operation mode I) when a different fuel is used for combustion. If the aqueous phase of pyrolysis oil is also used as a heat source, the total LHV efficiency drops to $\sim 27 \%$ (operation modes II and III) due to the high heat duty that is needed to also evaporate the water in the combustor. These results point out that when using a dry fuel as a heat source, the gas phase gasification of the aqueous phase of pyrolysis oil (or other wet streams) may compete with supercritical water gasification ( $\mathrm{p}>200$ bar, $\mathrm{T} \approx 600{ }^{\circ} \mathrm{C}$ ) where the technology development is still in an embryonic stage [19]. For syngas for fuels and chemical production, usually a $\mathrm{H}_{2} / \mathrm{CO}$ ratio around 2-3 is desired. To stay in this limit, instead of only supplying steam, $\mathrm{CO}_{2}$ (or a mixture) could be added, which is often available from product gas upgrading. Instead of having a heat duty for steam generation, a heat duty for $\mathrm{CO}_{2}$ separation has to be taken into account.

Figure 3.10 shows the total and syngas LHV efficiency for varying catalytic bed temperature and pressure for feed combustion at a $\mathrm{S} / \mathrm{C}$ ratio of 1 (A) and 2 (B). Figure 3.10C shows the corresponding $\mathrm{H}_{2} / \mathrm{CO}$ ratios. The effect of pressure on the syngas LHV efficiency is clearly seen where the higher pressure methane is more favored. Increasing the temperature has a major impact on the maximum attainable syngas LHV efficiency (rest is in methane). It is evident that when a low or methane free syngas is envisaged at elevated pressures, the temperature of the catalytic bed has to be high $\left(\sim 900-1000{ }^{\circ} \mathrm{C}\right)$ to shift the chemical equilibrium toward syngas production. Commercial steam reforming 
already applies a temperature gradient over the reactor to achieve high methane conversions where the 'operating' temperature is around $800-850{ }^{\circ} \mathrm{C}$ but with a peak exit temperature of around $950{ }^{\circ} \mathrm{C}$. When comparing the overall attainable LHV efficiency at $\mathrm{p}=30 \mathrm{bar}, \mathrm{S} / \mathrm{C}=2$, and $\mathrm{T}=1000{ }^{\circ} \mathrm{C}$ and taking a purification step into account, the total LHV efficiency is comparable to the lower end of the reported range of commercial methane steam reforming (LHV efficiency $\approx 65-80 \%[20]$ ).

(A)

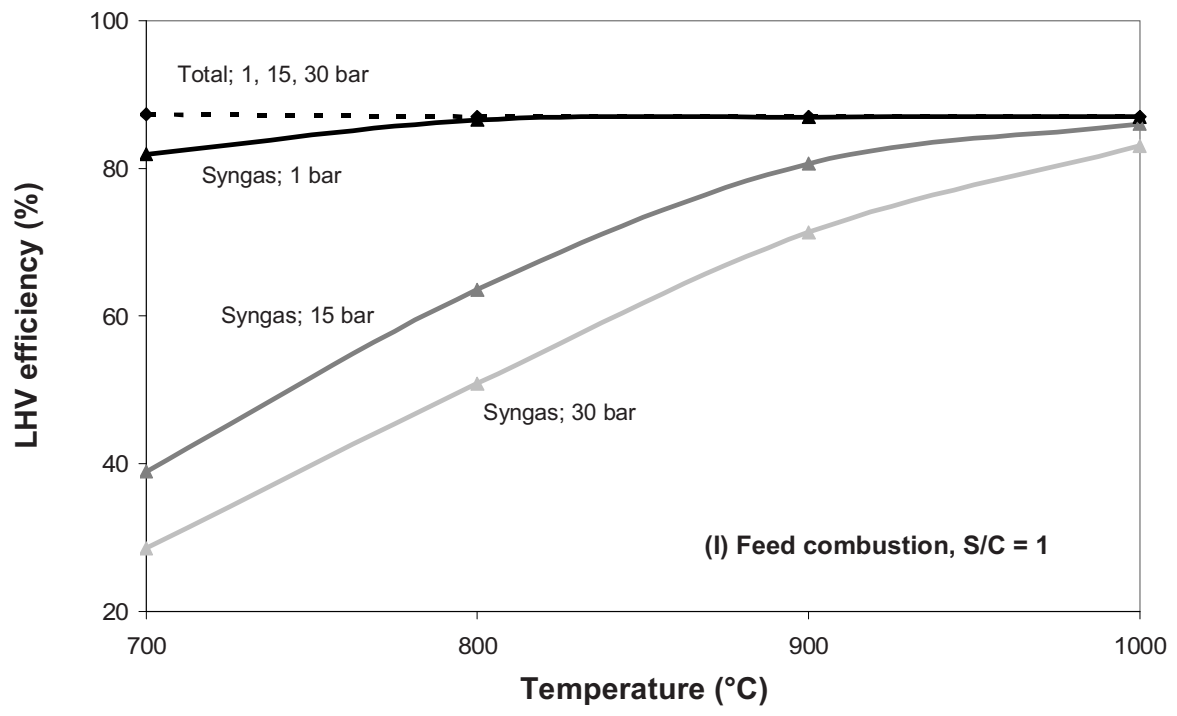


Staged Catalytic Gasification/Steam Reforming of Pyrolysis Oil

(B)

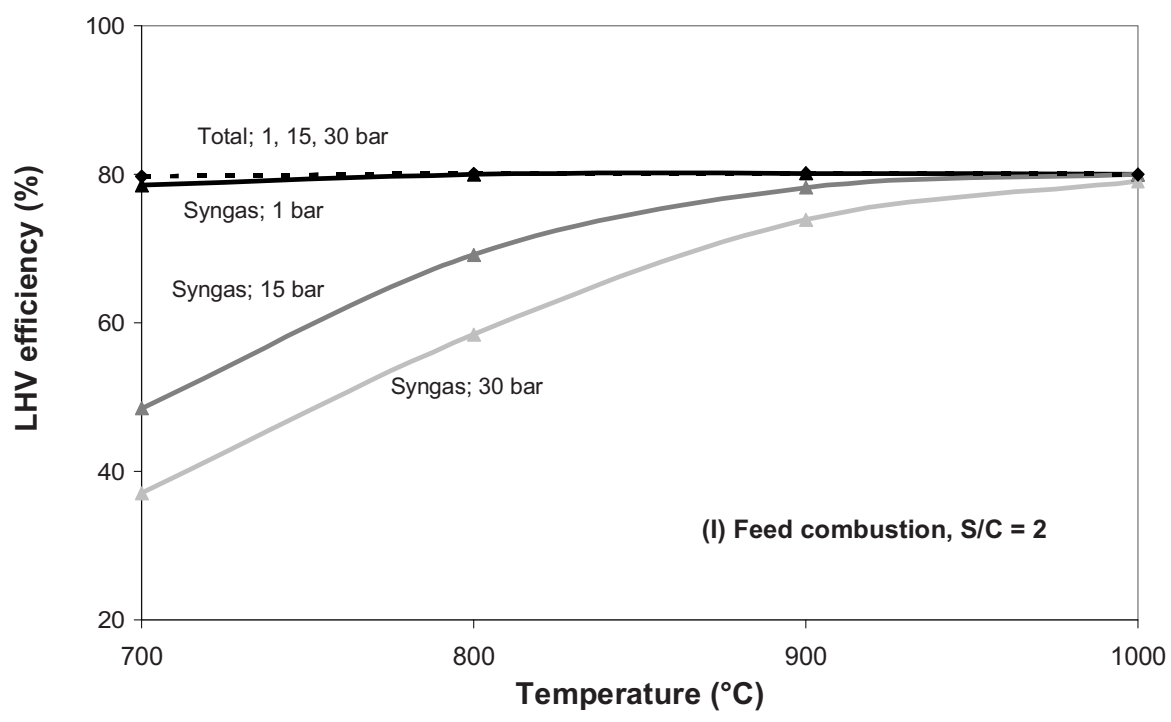

(C)

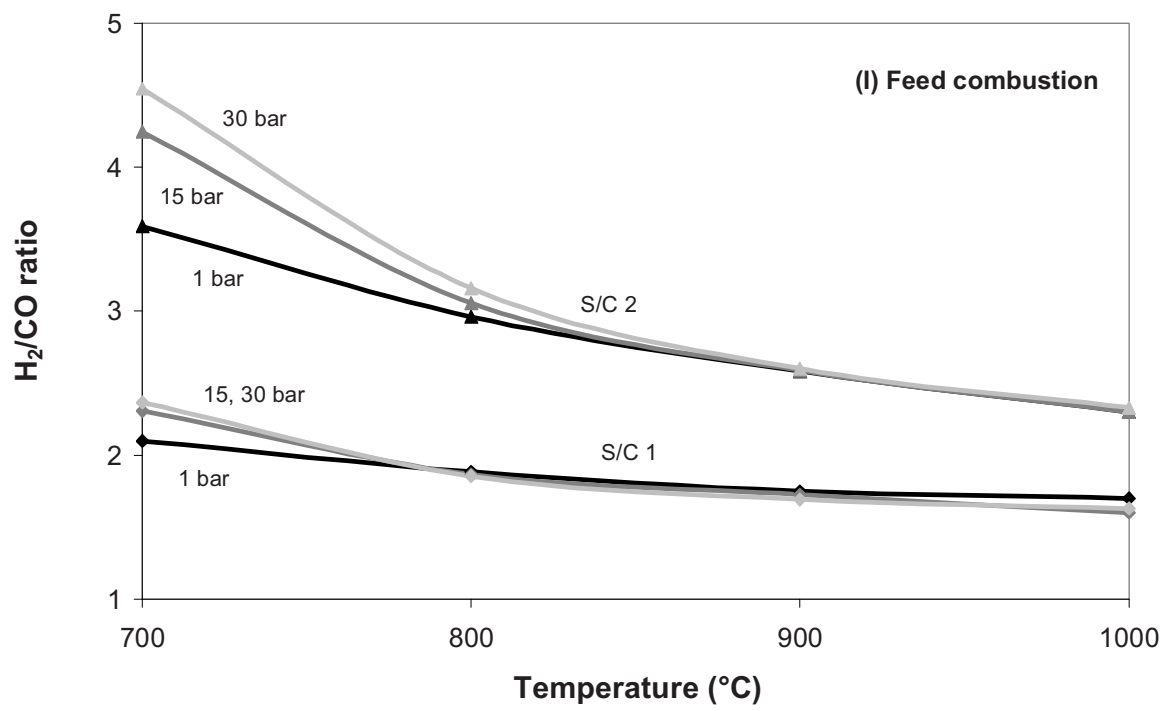

Figure 3.10. Total and syngas LHV efficiency versus catalytic bed temperature and pressure for feed combustion at a S/C ratio of 1 (A) and 2 (B). Part (C) shows the corresponding attained $\mathrm{H}_{2} / \mathrm{CO}$ ratios. 
The model calculations, while being very basic and not taking into account technical/chemical limitations, give a clear picture on how a gasification/reforming system should be operated for different applications.

Commercially, a pressurized gas is usually desired for further applications. An advantage of using pyrolysis oil is that it is easy to pressurize as compared to other solid biomass conversion routes. However, if a low or methane free syngas is envisaged as a product, a high catalytic bed exit temperature is needed for a high methane conversion. This is the case for Fischer-Tropsch fuels, alcohols, DME, and ammonia production and hydrogen for refineries. For pyrolysis oil reforming, a lower catalytic bed inlet temperature $\left(\sim 700^{\circ} \mathrm{C}\right)$ is desired because it enables direct vapor conversion, while coking on the catalyst does not yet occur to a great extent. Therefore, a temperature gradient $\left(\sim 200{ }^{\circ} \mathrm{C}\right)$ over the catalytic bed seems desirable. Another option would be to do atmospheric gasification/reforming and pressurizing the gas downstream, which will result in large reacting volumes. If methane with or without hydrogen is the desired product (for instance, as a substitute for natural gas), high pressure and low temperature operation is desired, which also results in a low or even an exothermic heat duty of the catalytic bed.

For the total LHV efficiency, the S/C ratio should be as low as possible. For the syngas LHV efficiency, the S/C ratio should be sufficient to allow methane conversion. To 'tune' the $\mathrm{H}_{2} / \mathrm{CO}$ ratio, besides steam addition also $\mathrm{CO}_{2}$ could be recycled back to the gasifier especially when ratios around 2 are desired.

External pyrolysis oil combustion (or a different fuel) gives the highest total LHV efficiencies. For this, the char that is being produced in the process should be sufficiently gasified in the available residence time. Gasification enhancing solid materials in the evaporator could facilitate this option (see Chapter 5).

For commercial applications, the gasification/steam reforming could also be integrated with downstream conversion of the produced gas to increase the efficiency. An example of such a (heat) integration analysis is given Appendix II in which the combination of pyrolysis oil reforming with high temperature stationary fuel cells for decentralized electricity production is investigated. Several process layouts have been explored by Aspen plus 11.1® software. These simulations have shown that recycling of the SOFC off-gas to the reformer can clearly improve the overall efficiency. 
The main conclusions of this work can be summarized as follows:

- The staged reactor concept can be readily used to gasify pyrolysis oil and other liquid biomass streams to syngas at lower heating value efficiencies comparable to commercial steam reforming of hydrocarbons. Commercial steam reforming catalysts are able to effectively produce a $\mathrm{CH}_{4}$ and $\mathrm{C}_{2}-\mathrm{C}_{3}$ free syngas at temperatures around $800{ }^{\circ} \mathrm{C}$ or higher at atmospheric pressure.

- The staged reactor concept can be used as a stand alone unit (providing heat from a combustor) or as an add-on to existing facilities where medium temperature heat $\left(\sim 450-600{ }^{\circ} \mathrm{C}\right)$ is available for evaporation and/or high temperature heat $(>750$ ${ }^{\circ} \mathrm{C}$ ) for reforming. Depending on the desired product gas, besides steam addition also $\mathrm{CO}_{2}$ addition/recycling can be used to tune the $\mathrm{H}_{2} / \mathrm{CO}$ ratio.

- By shifting the function of the fluid bed from a gasifier to an evaporator, methane and $\mathrm{C}_{2}-\mathrm{C}_{3}$ formation can be minimized in the fluid bed (less cracking of vapors). In this way, the subsequent catalyst bed will actually 'see' vaporized pyrolysis oil compounds instead of a fuel gas, which it can more readily convert to hydrocarbon lean syngas. This offers the opportunity to lower the catalytic loading and/or temperature (because of a higher activity of the catalyst for vapor than for methane steam reforming) and paves the way for the application of dedicated steam reforming catalyst for oxygenated compounds.

- While the temperature of the fluidized bed can be lowered to ca. $500{ }^{\circ} \mathrm{C}$, the temperature of the catalytic bed cannot be too low ( $\min 700{ }^{\circ} \mathrm{C}$ ) to avoid excessive carbon deposition.

- System calculations show that when pressurized (30 bar) pyrolysis oil gasification/reforming is envisaged, the catalytic exit bed temperature should be high to reach high enough methane conversion when syngas is the desired product. When only steam is added, the $\mathrm{H}_{2} / \mathrm{CO}$ ratio increases readily, which is desired for hydrogen production for ammonia an refineries. For Fischer-Tropsch fuels, DME, and alcohols production, probably $\mathrm{CO}_{2}$ has to be recycled to keep the $\mathrm{H}_{2} / \mathrm{CO}$ ratio around 2-3. 
Chapter 3 


\section{References}

1. Czernik, S.; Bridgwater, A. V. Overview of applications of biomass fast pyrolysis oil Energy Fuels 2004, 18, 590.

2. Aho, A.; Kumar, N.; Eränen, K.; Salmi, T.; Hupa, M.; Murzin, D. Y. Catalytic pyrolysis of woody biomass in a fluidized bed reactor: Influence of the zeolite structure. Fuel 2008, 87,2493 .

3. Westerhof, R. J. M.; Kuipers, J. M.; Kersten, S. R. A.; Van Swaaij, W. P. M. Controlling the water content of biomass fast pyrolysis oil. Ind. Eng. Chem. Res. 2007, 46, 9238.

4. De Miguel Mercader, F.; Ardiyanti, A.; Gutierrez, A.; Khromova, S.; Leijenhorst, E.; Kersten, S. R. A.; Hogendoorn, J. A.; Prins, W.; Groeneveld, M. J. Upgrading of bioliquids for co-processing in standard refinery units. Proceedings of the 16th European Biomass Conference and Exhibition, Valencia, Spain, June 2-6, 2008, 2103.

5. Levenspiel, O. What will come after petroleum. Ind. Eng. Chem. Res. 2005, 44, 5073.

6. Den Uil, H.; Van Ree, R.; Van der Drift, B.; Boerrigter, H. Duurzaam synthesegas: Een brug naar duurzame energie- en grondstoffen voorziening; ECN-C-04-015, Energy research Centre of the Netherlands, 2004.

7. Higman, C.; Van der Burgt, M. Gasification. Elsevier Science: New York, 2003.

8. Sutton, D.; Kelleher, B.; Ross, J. R. H. Review of literature on catalysts for biomass gasification. Fuel Process. Technol. 2001, 73, 155.

9. Van Rossum, G.; Potic, B.; Kersten, S. R. A.; Van Swaaij, W. P. M. Catalytic gasification of dry and wet biomass. Catal. Today 2009, 145, 10.

10. Czernik, C.; French, R.; Feik, C.; Chornet, E. Hydrogen by catalytic steam reforming of liquid byproducts from biomass thermoconversion processes. Ind. Eng. Chem. Res. 2002, $41,4209$. 
11. Van Rossum, G.; Kersten, S. R. A.; Van Swaaij, W. P. M. Catalytic and noncatalytic gasification of pyrolysis oil. Ind. Eng. Chem. Res. 2007, 46, 3959.

12. Margrini-Bair, K. A.; Czernik, S.; French, R.; Parent, Y. O.; Chornet, E.; Dayton, D. C.; Feik, C.; Bain, R. Fluidizable reforming catalyst development for conditioning biomassderived syngas. Appl. Catal. A 2007, 318, 199.

13. Felix, L.; Choi, C.; Rue, D.; Slimane, R.; West, L.; Seward, T. Glass-ceramic catalysts for tar decomposition and GTL synthesis in biomass gasification. Proceedings of the 16th European Biomass Conference Exhibition, Valencia, Spain, June 02-06, 2008, 1067.

14 Westerterp, K. R.; Van Swaaij, W. P. M.; Beenackers, A. A. C. M. Chemical Reactor Design and Operation, John Wiley \& Sons Ltd.: Great Britain, 1998.

15. Kersten, S. R. A.; Prins, W.; Van der Drift, A.; Van Swaaij, W. P. M. Interpretation of biomass gasification by "quasi”-equilibrium models. Proceedings of the 12th European Biomass Conference and Exhibition, Amsterdam, The Netherlands, June 17-21, 2002, 772.

16. Rostrup-Nielsen, J. R.; Sehested, J.; Nørskov, J. K. Hydrogen and synthesis gas by steamand $\mathrm{CO}_{2}$ reforming. Adv. Catal. 2002, 47, 66 .

17. Bleeker, M. F.; Veringa, H. J.; Kersten, S. R. A. Production of hydrogen with the steamiron process using pyrolysis oil. Ind. Eng. Chem. Res., submitted.

18. Reid, R. C.; Prausnitz, J. M.; Poling, B. E. The Properties of Gases and Liquids, McGraw-Hill Book Co.: Singapore, 1988.

19. Matsumura, Y.; Minowa, T.; Potic, B.; Kersten, S. R. A.; Prins, W.; Van Swaaij, W. P. M.; Van de Belt, B.; Elliott, D. C.; Neuenschwander, G. G.; Kruse, A.; Antal, M. J. Biomass gasification in near- and supercritical water: Status and prospects. Biomass Bioenerg. 2005, 29, 269.

20. Holladay, J. D.; Hu, J.; King, D. L.; Wang, Y. An overview of hydrogen production technologies. Catal. Today 2009, 139, 244. 


\title{
Chapter 4
}

\author{
Evaporation of Pyrolysis Oil: \\ Product Distribution and Residue Char Analysis
}

\begin{abstract}
The evaporation of pyrolysis oil was studied at varying heating rates $\left(\sim 1-10^{6}{ }^{\circ} \mathrm{C} / \mathrm{min}\right)$ with surrounding temperatures up to $850^{\circ} \mathrm{C}$. A total product distribution (gas, vapor and char) was measured using two atomizers with different droplet sizes. It was shown that with very high heating rates $\left(\sim 10^{6}{ }^{\circ} \mathrm{C} / \mathrm{min}\right)$, the amount of char was significantly lowered $(\sim 8 \%$, carbon basis) compared to the maximum amount which was produced at low heating rates using a TGA ( 30\%, carbon basis; heating rate $\left.1{ }^{\circ} \mathrm{C} / \mathrm{min}\right)$. The char formation takes place in the $100-350{ }^{\circ} \mathrm{C}$ liquid temperature range due to polymerization reactions of compounds in the pyrolysis oil. All pyrolysis oil fractions (whole oil, pyrolytic lignin, glucose and aqueous rich/lean phase) showed charring behavior. The pyrolysis oil chars age when subjected to elevated temperatures $\left(\geq 700{ }^{\circ} \mathrm{C}\right)$, show similar reactivity towards combustion and steam gasification compared to chars produced during fast pyrolysis of solid biomass. However, the structure is totally different where the pyrolysis oil char is very light and fluffy. To be able to use the produced char in conversion processes (energy or syngas production) it will have to be anchored to a carrier.
\end{abstract}

A manuscript based on this Chapter has been submitted to AIChE journal. 


\subsection{Introduction}

Syngas production from biomass can play an important role for producing renewable fuels and chemicals especially when waste streams are being considered. For logistics and processing advantages, pyrolysis oil is proposed to become an intermediate energy carrier as the new 'crude oil' for refining $[1,2]$.

To convert pyrolysis oil to syngas/hydrogen, which is the basis for the production and upgrading (hydrogen) of many fuels and chemicals, catalytic steam reforming is considered as a very attractive route since moderate process conditions can be applied and different scale sizes can be used as compared to high temperature entrained flow gasification [3].

When pyrolysis oil is being catalytically steam reformed, it is always accompanied by thermal reactions such as gasification and cracking. Already during the evaporation of the pyrolysis oil, three different products can be identified, namely: permanent gases, vapors and a carbonaceous solid material (here called char). Especially due to char formation, a fluidized bed has been preferred $[3,4]$ to steam reform pyrolysis oil since clogging of the reactor can be avoided. The char particles are then evenly distributed into the bed or elutriated from the bed. The distribution between these products is likely to be influenced by the heating trajectory of the pyrolysis oil droplet and the final evaporation temperature.

Various research groups [3-6] have steam reformed pyrolysis oil or its fractions in a single fluidized catalytic bed where in most cases, a relatively clean fuel gas was being produced. However, irreversible catalytic activity loss (leading to increasing methane levels) was being observed which has mostly been ascribed to attrition/sintering of the catalyst. Due to this, up till now, no long term operation of steam reforming (or its fractions) was feasible to see the influence of other impurities present in the pyrolysis oil (like sulfur) on the activity of the catalyst. Furthermore, optimization of the evaporation of pyrolysis oil is limited while using a single reactor because the reforming catalyst needs a high temperature to produce a methane free syngas at higher pressures due to the chemical equilibrium [7]. To overcome these problems which limits the applicability of the process, Van Rossum et al. $[3,7,8]$ proposed a staged reactor concept where the evaporation and catalytic conversion are decoupled using a fluidized bed for oil 
evaporation followed by a fixed bed which contains a steam reforming catalyst. In this way, optimization of both, essentially different, processes is possible. A clean syngas could be produced when both the fluidized and fixed bed were at a temperature $\sim 800{ }^{\circ} \mathrm{C}$. A decrease of the evaporation temperature showed promising results in such a way that the catalyst was able to actually 'see' primary tars (oxygenated pyrolysis vapors) which are easier to reform instead of a thermally cracked gas. A full carbon balance, however, could not be made since not all product streams could be analyzed; for instance formed char inside the fluidized bed was partly elutriated from both reactors and ended up in the condenser section. To have a high overall efficiency of the process, all char has to be converted in the process instead of partly being considered as a loss. For this two options seem likely: (i) the char is either combusted in a separated combustor to supply heat for the endothermic steam reforming reactions and evaporation (ii) or the char is kept in the reactor and gasified using steam and/or $\mathrm{CO}_{2}$. An efficiency evaluation [7] showed that internal gasification is preferable. Additionally, this option would also allow an easier process operation; external heating is easier to control than maintaining a heat carrier circulation especially at elevated pressures.

To get more insight in the evaporation of pyrolysis oil, the process is isolated and studied in this Chapter. Initially, the effect of temperature, droplet size and heating rate on the product distribution (char, vapor and gas) is studied. Secondly, the produced chars are evaluated on its general properties, reactivity and shape. Finally, the implications will be discussed on designing a process for steam reforming of pyrolysis oil.

\subsection{Experimental}

\subsubsection{Materials}

The pyrolysis oils were produced in the Process Development Unit of VTT, Finland [9]. Two different biomass sources were used, namely pine wood (PW) and forest residue (FR). The forest residue oil was also separated into an aqueous rich and aqueous lean phase via water addition. Pyrolyctic lignin was obtained by adding pine pyrolysis oil into ice-cooled water as described by Scholze et al. [10]. Activated carbon was obtained from 
Norit. The corresponding elemental analyses and water determinations are given in Table 4.1.

Table 4.1. Elemental analyses (wet) and water content determinations of the pyrolysis oils and related fractions/compounds used. The rest is mainly oxygen with also compounds like sulfur, nitrogen and ash.

\begin{tabular}{c|cccc}
\hline (wt\%) & $\mathbf{C}$ & $\mathbf{H}$ & Rest & $\mathbf{H}_{2} \mathbf{O}$ \\
\hline Pyrolysis oil (PW) & 41.1 & 7.4 & 51.5 & 24.5 \\
Pyrolysis oil (FR) & 40.6 & 7.6 & 51.8 & 23.9 \\
Aqueous rich phase (FR) & 23.3 & 9.4 & 67.3 & 52.1 \\
Aqueous lean phase (FR) & 48.8 & 7.5 & 43.7 & 12.3 \\
Wood (PW) & 45.6 & 5.8 & 48.6 & 6.8 \\
Pyrolytic lignin (PW) & 61.2 & 6.1 & 31.7 & n.d. \\
Wood pyrolysis char (PW) & 88.7 & 2.5 & 7.5 & n.d. \\
Activated carbon (Norit) & 85.9 & 0.6 & 13.5 & n.d. \\
& (n.d. $\rightarrow$ not determined) & &
\end{tabular}

\subsubsection{Continuous pyrolysis oil evaporation}

To quantify the distribution of pyrolysis oil during evaporation between the gas, vapor and char phase, a dedicated continuous pyrolysis evaporation setup was constructed. A schematic overview of the setup is given in Figure 4.1. Pyrolysis oil (FR $100 \mathrm{ml} / \mathrm{h}$, duration ca. $\left.1 \mathrm{~h} ; \mathrm{C}_{\text {in_oil }}\right)$ was sprayed into an empty electrically heated stainless steel tube (diameter $40 \mathrm{~mm}$, length $400 \mathrm{~mm}$ ) using two different externally cooled atomizers. Two thermocouples were placed inside the reactor to record the actual temperature in the middle of the reactor during evaporation experiments. The reported reactor temperatures are averaged values of the two thermocouples over the whole experiment. The reactor temperature was varied between $499-847{ }^{\circ} \mathrm{C}$. The two different atomizers were used to create two different extremes of sizes of droplets which were measured by pictures taken with a high speed camera (Photron Fastcam SA1). An ultrasonic atomizer (UA; Lecher US1, spraying angle $30^{\circ}$ ) created a droplet size distribution of which the largest droplets were measured to be $88-117$ micron (assisting gas $\mathrm{N}_{2} 4.0 \mathrm{Nl} / \mathrm{min}$ ). However, the majority of the droplets were much smaller but below the resolution limit of the camera. The atomizer was specified for water to have a Sauter mean diameter of 30 micron. For 
pyrolysis oil it is expected to be somewhat higher due to the higher viscosity. A house-made (UT) atomizer consisted of a needle which was surrounded by an assisting gas $\left(\mathrm{N}_{2} 2.5 \mathrm{Nl} / \mathrm{min}\right)$. A uniform droplet was formed with a diameter of $\sim 1.9 \mathrm{~mm}$. Additional preheated $\mathrm{N}_{2}$ was added directly under the atomizer in a circular way to avoid vapor condensation on the cooler of the atomizer and to keep the residence time of the gases around 2-3 s over the temperature range measured. At the end of the evaporation chamber a filter (mesh size 5 micron) was placed which together with a small sand layer and enough surface area resulted in a pressure drop of maximal 0.3 bar. The filter temperature was always lower than the reactor temperature $\left(\mathrm{T}=498-665{ }^{\circ} \mathrm{C}\right)$. After the filter the stream was split into two streams: (i) one going to a combustor where the produced gas/vapor mixture was totally combusted with pure oxygen producing $\mathrm{CO}_{2}$ and $\mathrm{H}_{2} \mathrm{O}$. This gas flow was kept constant with a membrane pump which was placed after a condenser. (ii) the other directly fed to a quenching water bath which was mechanically stirred to quickly cool the gas/vapor mixture and trap the condensables. Two micro-GC's (2x Varian CP-4900; detecting $\mathrm{N}_{2}, \mathrm{H}_{2}, \mathrm{CH}_{4}, \mathrm{CO}, \mathrm{CO}_{2}, \mathrm{C}_{2} \mathrm{H}_{4}, \mathrm{C}_{2} \mathrm{H}_{6}, \mathrm{C}_{3} \mathrm{H}_{6}$ and $\mathrm{C}_{3} \mathrm{H}_{8}$ ) measured the gas composition of the combustor $\left(\mathrm{C}_{\text {out_vapor+gas }}\right)$ and of the quench stream $\left(\mathrm{C}_{\text {out_gas }}\right)$. The integral carbon balance was made based on nitrogen as an internal standard which was fed to the evaporator. After an experiment the collected char on the filter was either collected for analysis and reactivity testing or it was combusted $\left(\mathrm{C}_{\text {out_char }}\right)$ to make a total carbon balance over the system. The carbon to gas ratios and char conversions are measured directly and the carbon to vapor conversion is calculated by the difference between the combustor and quench stream according to:

$C_{\text {out_vapor }}=C_{\text {out__astvapor }}-C_{\text {out_gas }}$

Distribution:

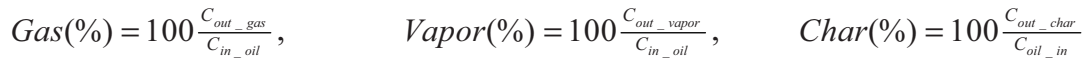

The carbon closure of the three different sections was found to be adequate: (i) Gas only: $101 \pm 1 \%$ based on methane addition and recovery in both the combustor and gas+vapor 
line, (ii) Gas+vapor: acetic acid was evaporated and partially thermally cracked ( $\mathrm{T} \sim 720-750{ }^{\circ} \mathrm{C}, \mathrm{S} / \mathrm{C} \sim 2.5-5.0$ ). Here, no char is being formed: carbon recovery $96 \pm 1 \%$, (iii) Solid: wood pyrolysis char was combusted with a carbon recovery of $97 \pm 2 \%$. The carbon recovery of all the pyrolysis oil evaporation experiments (gas + vapor + solid) was $98 \pm 4 \%$.

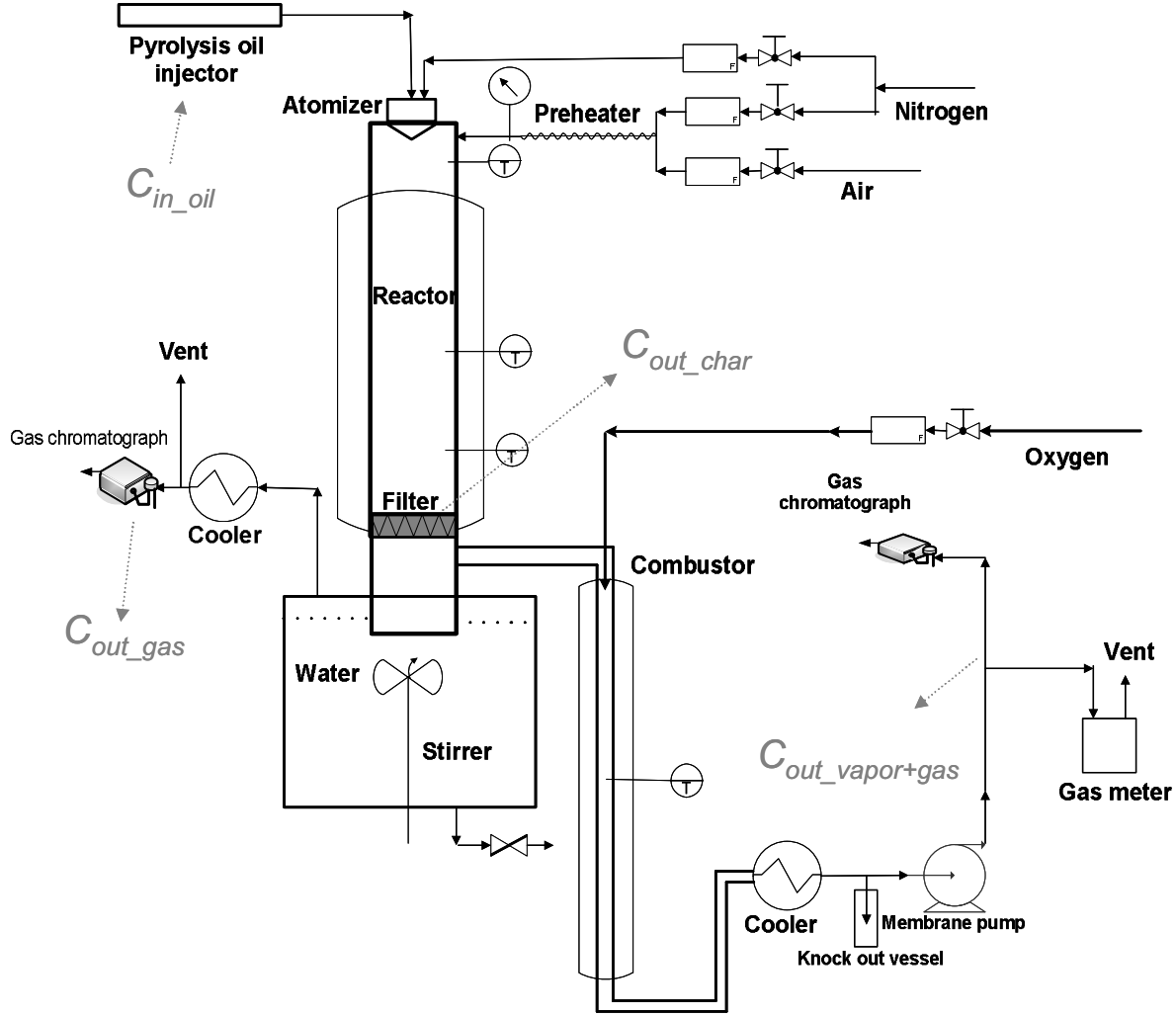

Figure 4.1. Schematic overview of the continuous pyrolysis evaporation setup for measuring the carbon distribution from the oil to gas, vapor and char. The amount of gas and char are measured directly, the vapor amount is calculated by difference. 


\subsubsection{Batch wise pyrolysis oil evaporation}

A fixed amount of pyrolysis oil (FR, $1.4 \pm 0.1 \mathrm{~g}$ ) was added to the bottom of a glass tube (diameter $10 \mathrm{~mm}$ ). The glass tube was placed inside a narrow fitting electrically heated oven and the temperatures were measured inside the oil itself and inside the oven (between the glass tube and alumina oven element). The oil was heated to the desired temperature and kept there (total time $1 \mathrm{~h}$ ) and then either cooled down to room temperature or further heated to $550{ }^{\circ} \mathrm{C}$ for 1 additional hour and then cooled down. The remaining solid/liquid is called 'Residue' and 'Char', respectively. A small nitrogen flow was placed just above the oil to avoid direct contact with air and to remove the vapors which were released during evaporation. The remaining 'Residue'/'Char' was weighed. The 'Residue' which was completely (or almost) soluble in tetrahydrofuran (THF) was analyzed with Gel Permeation Chromatography with THF as elutriation liquid and calibrated using polystyrene [11].

\subsubsection{Thermogravimetric Analysis}

Heating experiments (mainly pyrolysis oil) were performed in a Mettler Toledo thermogravimetric analyzer (TGA). The samples were heated to $800{ }^{\circ} \mathrm{C}$ at a rate of 1,10 or $100{ }^{\circ} \mathrm{C} / \mathrm{min}$ in argon $(60 \mathrm{ml} / \mathrm{min})$. Combustion experiments were performed in the same system. In combustion mode, the samples were heated to $800{ }^{\circ} \mathrm{C}$ at a rate of $5{ }^{\circ} \mathrm{C} / \mathrm{min}$ in a mixture of air $(20 \mathrm{ml} / \mathrm{min})$ and $\operatorname{argon}(40 \mathrm{ml} / \mathrm{min})$.

Additional to the TGA balance, the overall weight loss of the sample was quantified with a very accurate $( \pm 0.1 \mathrm{mg})$ external balance since some weight loss was already observed during the stabilization time of the TGA. Two different weight rate losses are defined:

$$
\begin{array}{ll}
r_{w T} \equiv \frac{d X}{d T}=-\frac{\left(m_{\tau}-m_{\tau+1}\right)}{m_{0}\left(T_{\tau}-T_{\tau+1}\right)} \quad \text { at a constant heating rate } & \left(\frac{1}{{ }^{\circ} C}\right) \\
r_{w t} \equiv \frac{d X}{d t}=-\frac{\left(m_{\tau}-m_{\tau+1}\right)}{m_{0}\left(t_{\tau}-t_{\tau+1}\right)} & \left(\frac{1}{s}\right)
\end{array}
$$

where $\tau$ and $\tau+1$ are logged times, $\mathrm{T}\left({ }^{\circ} \mathrm{C}\right)$ the temperature of the sample cup and $\mathrm{m}_{0}(\mathrm{mg})$ the initial amount of pyrolysis oil as weighted with the external balance. The overall char 
weight conversions $(\mathrm{X})$ and carbon to char conversions were calculated using the external balance.

\subsubsection{Steam gasification of char}

To gasify, a quartz tube (diameter $45 \mathrm{~mm}$, length $400 \mathrm{~mm}$ ) was used which was placed inside an electrically heated oven. A steam generator was used to create a steady steam flow $\left(\sim 300^{\circ} \mathrm{C}, 0.15-0.5 \mathrm{~g} / \mathrm{min}\right)$ and preheated nitrogen $\left(\sim 200^{\circ} \mathrm{C}, 9 \mathrm{ml} / \mathrm{min}\right)$ was added as an internal standard. The amount of steam added compared to the char sample (ca. $4-10 \mathrm{mg}$ ) was high enough that steam conversions below $1 \%$ were obtained. The char sample was placed at the end of the oven to ensure adequate preheating of the steam/nitrogen and allow isothermal gasification. The char sample to be gasified was pre-mixed with quartz (0.2-0.6 g) to lower the pressure drop which can be created due to the fine structure of the char. The mixed sample (ca. $1 \mathrm{~cm}$ in length) was held in the upper part of the heated quartz tube using quartz wool on both sides. Some pressure drop (0.2-0.5 bar) over the sample was being observed. The reactor outlet was cooled and all the steam was condensed out of the sample gas. A micro-GC (Varian CP-4900) was used to analyze the gas composition from which the carbon conversion was calculated. The gasification rate $\left(\mathrm{r}_{\mathrm{wt}}, \mathrm{dX} / \mathrm{dt}\right)$ was assumed to directly correspond to the calculated carbon conversion rate which introduces a small error since most of the char sample consists out of carbon ( $75 \%$ or more) but also some oxygen and hydrogen are present.

\subsection{Results pyrolysis oil evaporation}

\subsubsection{Continuous pyrolysis oil evaporation: product distribution}

Figure 4.2 shows the carbon distribution to permanent gas, vapor and solid phase for both the ultrasonic (UA) and the needle (UT) atomizer using forest residue pyrolysis oil. Over the whole temperature range measured the amount of char produced seems to be constant or a very slight decrease is being observed with increasing temperature. This indicates that the initial distribution between char and vapors/gases is apparently already attained in the temperature trajectory up to $500{ }^{\circ} \mathrm{C}$, an observation which is in line with earlier work [7,12]. The vapor production decreases with increasing temperature and the 
amount of gases increases opposite to the vapor production. A big difference is seen in char production between the two atomizers where the ultrasonic atomizer gives much less char compared to the needle atomizer, $\sim 8 \%$ and $\sim 22 \%$ on carbon basis, respectively. The vapor production seems more or less comparable. However, it is likely that initially more vapors are being produced using the UA atomizer leading to less char and that the main conversion pathway for gas production is via vapor cracking. Small droplets (UA) are much quicker evaporated than larger droplets (UT) and in this way vapors have more time to be cracked to permanent gases.

Compared to the fluidized and staged reactor bed system used by Van Rossum et al. [3] (and Chapters 2 and 3) to study the gasification/steam reforming of pyrolysis oil, for the present setup much more vapors are being measured ( 20-30 wt $\%$ versus $\sim 1 \mathrm{wt} \%$ on carbon basis at $\mathrm{T} \sim 800{ }^{\circ} \mathrm{C}$, noncatalytic). This difference is probably caused by the longer residence time at high temperatures, which enhances thermal vapor cracking $(\sim 10 \mathrm{~s}$ versus 2-3 s).

(A)

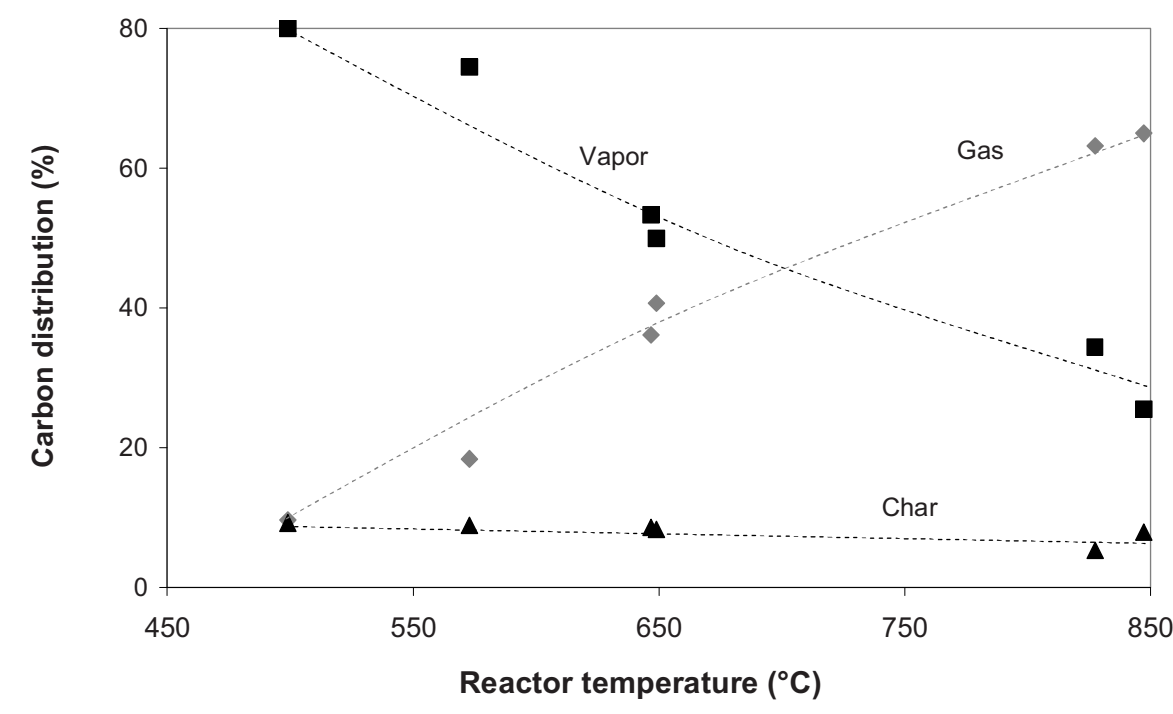


(B)

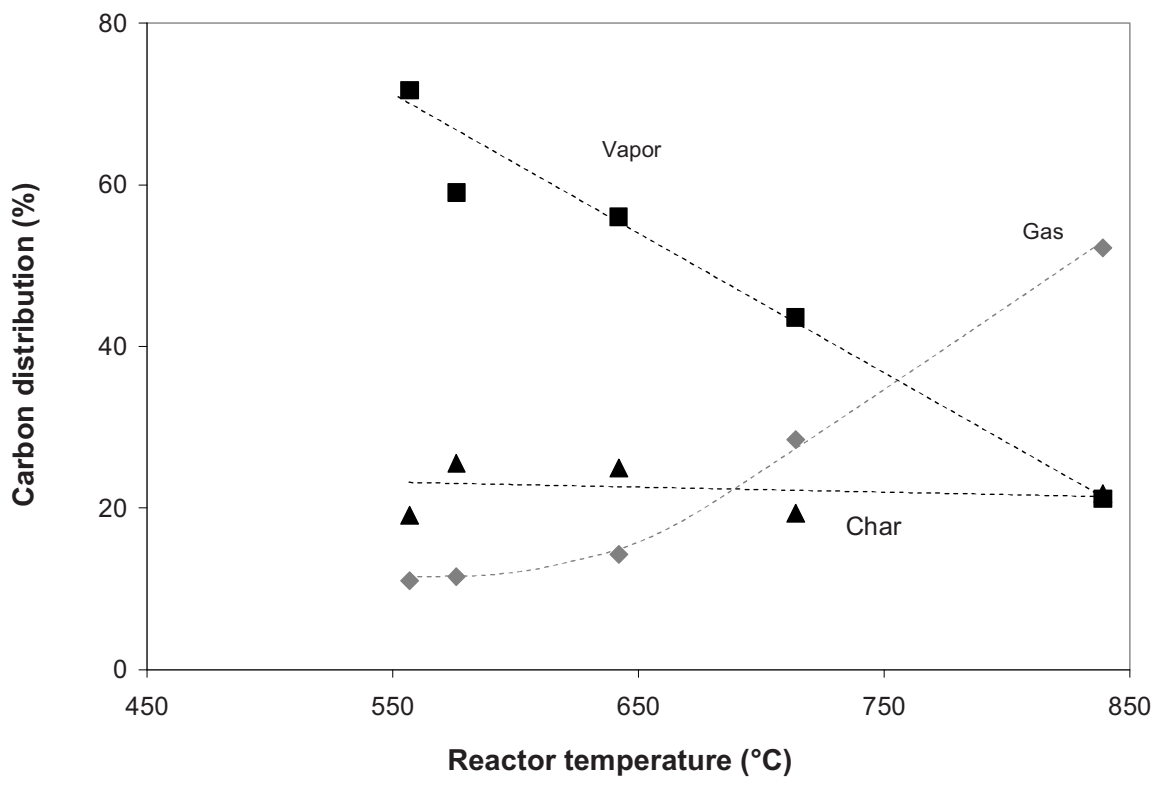

Figure 4.2. $(\mathrm{A}+\mathrm{B})$ carbon distribution over the gas, vapor and solid (char) phase during the evaporation of FR pyrolysis oil using an ultrasonic (A, UA) and needle (B, UT) atomizers at a pyrolysis oil feeding rate of $100 \mathrm{ml} / \mathrm{h}$.

\subsubsection{Batch wise pyrolysis oil evaporation: residue analysis}

Figure 4.3 and Table 4.2 shows the results of the pyrolysis oil evaporation carried out in glass reactor tubes which are heated at $\sim 50{ }^{\circ} \mathrm{C} / \mathrm{min}$ (oven) to different temperatures. The residue (Figure 4.3A) shows a steady decrease in amount with increasing temperature which stabilizes around $\mathrm{T} \sim 500{ }^{\circ} \mathrm{C}$. The amount of char shows more or less a constant production ( $\sim 17 \mathrm{wt} \%, \sim 32 \%$ carbon basis) although the time-temperature trajectory has been totally different. The heating trajectory shows quite a difference between the measured oven temperature and the actual sample temperature. The oven temperature (Figure 4.3B), which is usually measured in heating experiments as for instance with a TGA, shows roughly a constant heating rate till its setpoint temperature. However, the sample temperature strongly deviates from the oven heating trajectory and shows four heating stages as is best illustrated for the $\mathrm{T}_{\text {oven }}=550{ }^{\circ} \mathrm{C}$ experiment: 
- 0-3 min: heating of the liquid, some vapor release can already be visually observed.

- 3-5 min: the liquid temperature increases very slow; this can predominantly be ascribed to water which is evaporated together with some lights. The vapors which are being released are colorless and transparent. The difference in oven and sample temperature almost reaches $200{ }^{\circ} \mathrm{C}$.

- 5-9 min: the sample temperature increases at a constant heating rate. The vapors which are being released get more and more dark with increasing temperature and at a sample temperature $\sim 220{ }^{\circ} \mathrm{C}$ a phase transition occurs and a solid is being formed which is accompanied with a volumetric expansion ( $\sim$ three times) which has also been described by Wornat et al. [13] during the combustion of pyrolysis oil.

- 9 min-end: the sample temperature reaches a constant value/level and the vapor release stops. The produced char has a very porous structure and is brittle.

(A)

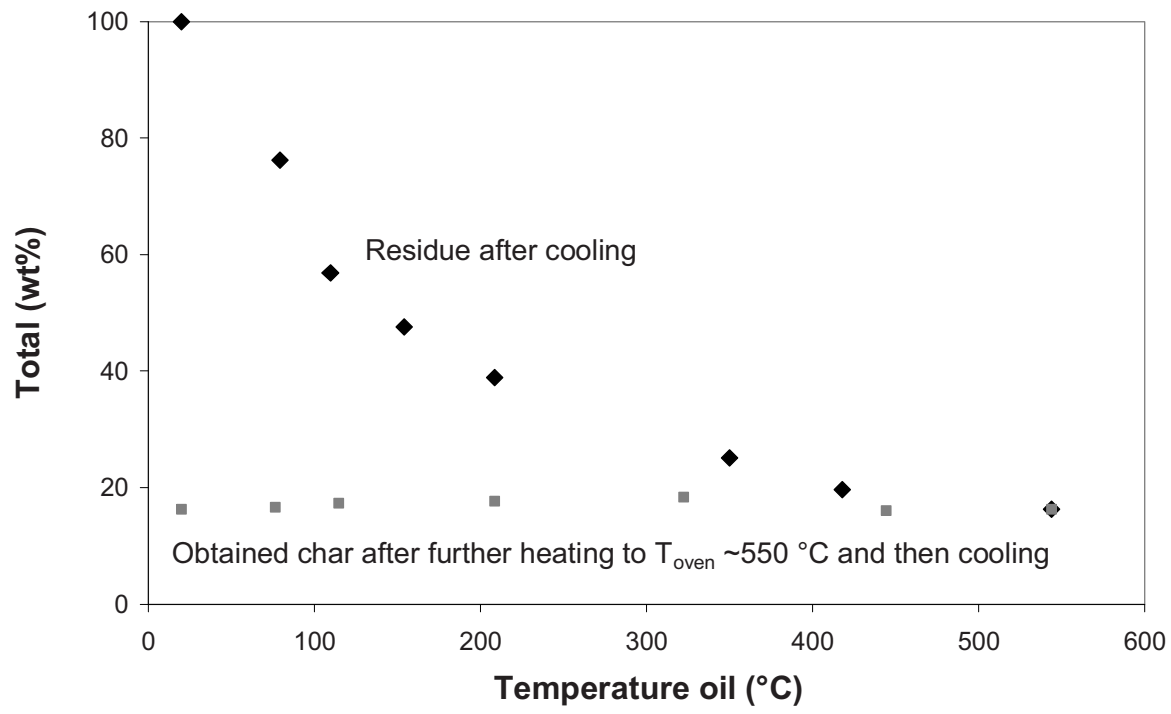


(B)

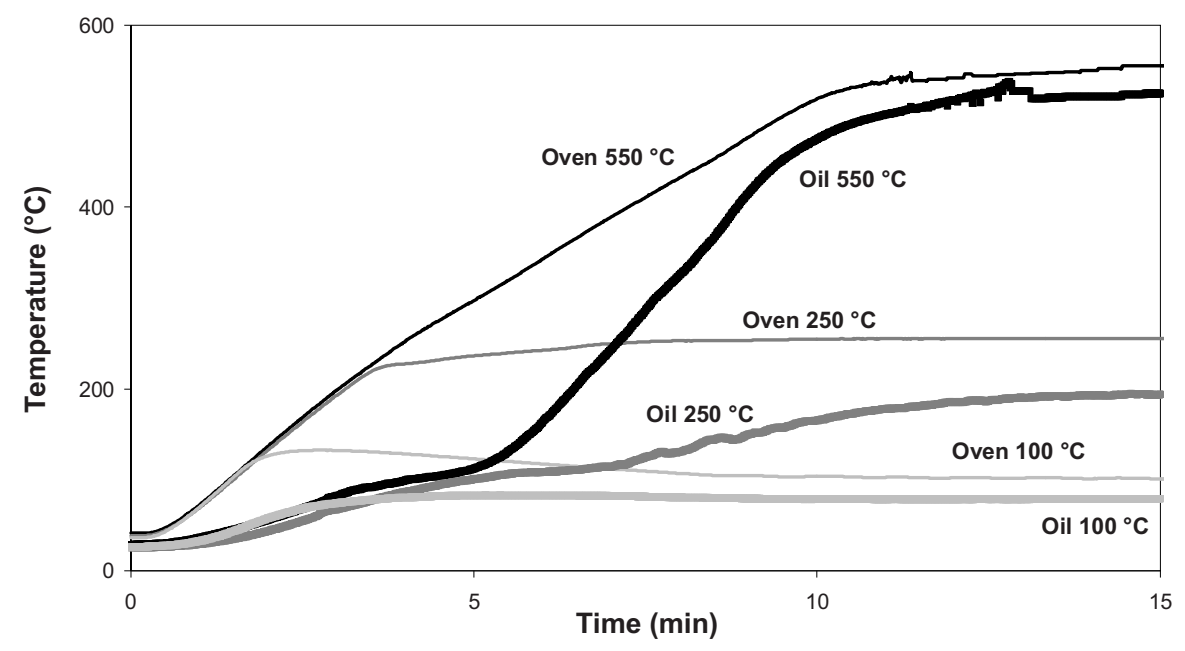

Figure 4.3. Results of pyrolysis oil evaporation done in glass reactor tubes. (A) residue after a heating-cooling cycle and char after a heating-further heating-cooling cycle. (B) temperature profiles of both the oven (heating rate ca. $50^{\circ} \mathrm{C} / \mathrm{min}$ ) and the liquid/solid itself at three different oven set-points, namely: 100,250 and $550^{\circ} \mathrm{C}$.

Table 4.2. Averaged temperatures (at 'steady-state') and solubility of the obtained 'Residue' in THF (T: totally, P: partly, N: not soluble) from forest residue pyrolysis oil glass reactor tube

\begin{tabular}{c|cccccccc}
\multicolumn{10}{c}{ heating experiments. } \\
\hline \multicolumn{1}{c}{} & $\mathbf{1}$ & $\mathbf{2}$ & $\mathbf{3}$ & $\mathbf{4}$ & $\mathbf{5}$ & $\mathbf{6}$ & $\mathbf{7}$ & $\mathbf{8}$ \\
\hline $\mathbf{T}_{\text {oven }}\left({ }^{\circ} \mathbf{C}\right)$ & - & 101 & 152 & 203 & 254 & 368 & 452 & 556 \\
$\mathbf{T}_{\text {sample }}\left({ }^{\circ} \mathbf{C}\right)$ & 20 & 79 & 110 & 154 & 209 & 350 & 418 & 544 \\
Solubility in $\mathbf{T H F}$ & $\mathrm{T}$ & $\mathrm{T}$ & $\mathrm{T}$ & $\mathrm{T}$ & $\mathrm{T} / \mathrm{P}$ & $\mathrm{P}$ & $\mathrm{P}$ & $\mathrm{N}$
\end{tabular}

Figure 4.4 shows Gel Permeation Chromatography results of the residue samples 1 till 5 (Table 4.2) which were (almost) completely soluble in THF. The initial oil heating, which is accompanied with already some vapor release, did not result in a significant differences in the profile of the distribution of the higher fractions present in pyrolysis oil. 
This suggests that even though the oil was at $79^{\circ} \mathrm{C}$ for almost an hour, no significant polymerization, which would result in heavier product formation, took place. Further heating of the oil created heavier fractions as seen in the increasing molecular weight measured with the GPC. This is also in line with the observation of lesser solubility in THF and the visual change from liquid to solid during the experiment. This suggests that polymer formation takes place in the liquid phase directly after water (and lights) evaporation $\left(\mathrm{T}_{\text {liquid }}>100{ }^{\circ} \mathrm{C}\right.$ ). These polymers eventually react further to char (solvent insoluble) fractions which were observed from $250{ }^{\circ} \mathrm{C}$ (see Table 4.2).

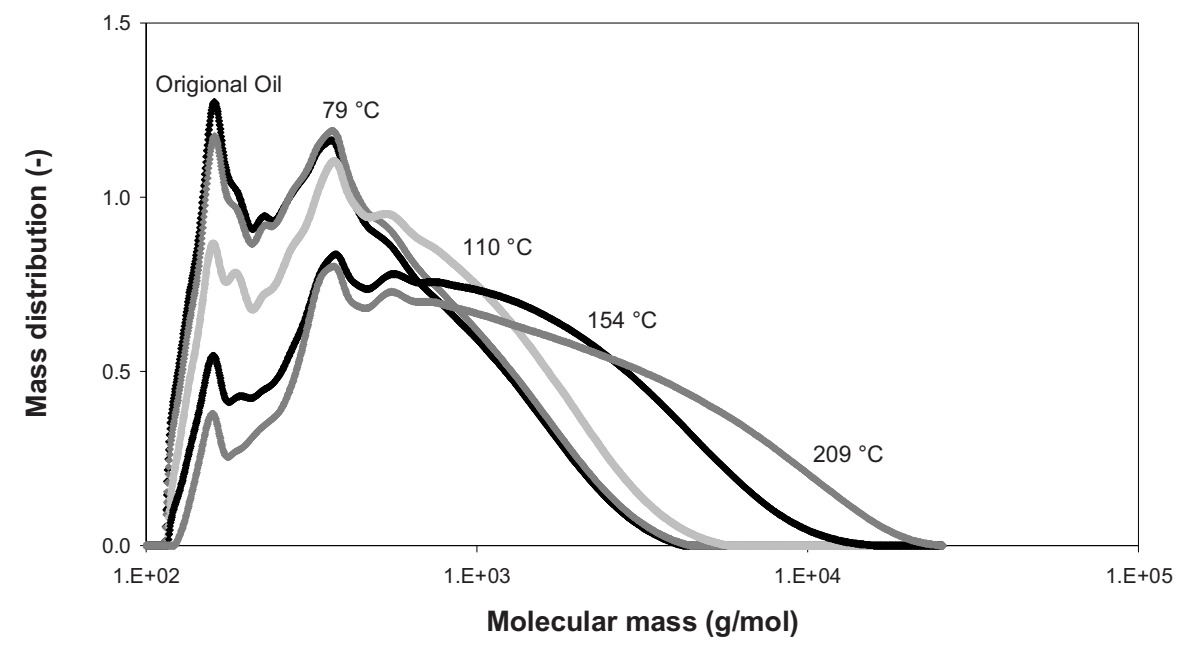

Figure 4.4. Gel Permeation Chromatography results of the original pyrolysis oil (sample 1) and of residues after heating (samples 2 till 5). The displayed temperatures are of the actual liquid (at 'steady-state').

\subsubsection{TGA: evaporation}

Figure 4.5 shows the evaporation of pyrolysis oil using TGA with increasing sample cup temperature. Table 4.3 shows the amounts of char (both weight and carbon basis) being produced with TGA for pyrolysis oil and related fractions/compounds.

When the heating rate is varied, the following observations can be made:

- In the initial heating stage (up to $175^{\circ} \mathrm{C}$ ), a clear peak of mass release (Figure $4.5 \mathrm{~B})$ can be identified. This is the evaporation of water and lights when the liquid 
temperature is almost constant similar to as can be seen in Figure 4.3B (region 3-5 $\mathrm{min}$ in the $\mathrm{T}_{\text {oven }}=550{ }^{\circ} \mathrm{C}$ experiment).

- The $\mathrm{dX} / \mathrm{dt}$ profile (Figure 4.5C) shows that between the three experiments roughly a factor of 10 change in conversion rate is being observed which corresponds to the step change applied in the heating rates. This indicates that the reactions/evaporation of the component groups seem to follow first order kinetic behavior which has been the basis for modeling pyrolysis oil droplet evaporation $[12,14]$.

- The $\mathrm{dX} / \mathrm{dT}$ (Figure 4.5B) profiles are quite similar. The small differences observed are most likely caused by a difference in actual liquid sample temperature and sample cup temperature which is expected to be large at high heating rates (next to the first order behavior of the evaporation and reactions).

- The carbon to char conversion shows a slight trend of increasing char production with lower heating rates. The produced char amounts are similar to the glass tube heating experiments and higher than the droplet evaporation experiments.

The heating of different fractions of pyrolysis oil and related compounds (Table 4.3) all resulted in the formation of considerable amounts of char. The aqueous rich fraction of pyrolysis oil, which is considered to be an important hydrogen source and easy to steam reform $[4,5]$, still resulted in $24 \%$ of carbon which was converted to char. The heavier fractions of pyrolysis oil (aqueous lean phase and pyrolictic lignin) form high amounts of char. The amount of char formed with evaporating pyrolysis oil is under slow heating rates $\left(1-100{ }^{\circ} \mathrm{C} / \mathrm{min}\right)$ similar to pyrolysis of solid biomass at $\sim 500{ }^{\circ} \mathrm{C}(25 \%$ carbon to char conversion, Table 4.3). It is striking that such high amounts of char are formed since the large molecular structures which were present in the original biomass are being depolymerized in the pyrolysis process to end up in the pyrolysis oil or are mainly concentrated in the char byproduct. Char formation during pyrolysis oil evaporation seems to be mainly due to polymerization reactions of the oil as illustrated in Figure 4.4.

However, some polymerization reactions can already take place during the pyrolysis oil production/condensation directly leading to products which can not be re-evaporated. It is then interesting to see if these products can be readily gasified or that they always lead to the production of char. 
It will be important to heat up quickly through the $100 \rightarrow 350{ }^{\circ} \mathrm{C}$ temperature zone where the polymerization takes place. The lower amount of char formation at higher heating rates shows clearly that steering is possible. Figure 4.6 shows heating rates for the TGA, heated glass tubes and droplet evaporation. The 'droplet evaporation' heating rates after 'lights' evaporation when char formation starts were estimated with a heat balance over a droplet according to:

$\frac{d T}{d t}=\frac{6 N u \lambda}{c_{p} \rho d_{p}{ }^{2}} \Delta T \quad$ with Nusselt (flow around sphere) $\quad N u=2+0.66 \operatorname{Re}^{\frac{1}{2}} \operatorname{Pr}^{\frac{1}{3}} \approx 7$

With $d_{p}$ the droplet size of the pyrolysis oil, $c_{p}$ the heat capacity of a liquid $\sim 2000 \mathrm{~J} / \mathrm{kg} /{ }^{\circ} \mathrm{C}, \rho$ the density of the liquid $\sim 1000 \mathrm{~kg} / \mathrm{m}^{3}, \lambda$ thermal conductivity of gas $\sim 0.06 \mathrm{~W} / \mathrm{m} /{ }^{\circ} \mathrm{C}$ and $\Delta \mathrm{T}$ the temperature difference $\sim 500{ }^{\circ} \mathrm{C}$ (a $50 \%$ spread over the calculated heating rate values is assumed in Figure 4.6). The estimated heating rates are in the same order of magnitude as estimated by García Pérez et al. [15]. Only very high heating rates $\left(\geq 10^{5}{ }^{\circ} \mathrm{C} / \mathrm{min}\right)$ results in significant reductions of char production. This shows that with widely used heating analyzing equipment such as TGA, an analysis can be made of maximum char production that is probable from a certain compound/oil This can be useful to predict gasification behavior but it must be kept in mind that the process of evaporation is most likely/essentially different between a TGA and an atomizer. Probably there is also a minimum amount of char which will be formed. Glucose like compounds and heavier fractions are always present in the pyrolysis oil (both aqueous rich and lean phases) which tend to polymerize rather than to evaporate/decompose (see Table 4.3). However, it is possible that with extremely high heating rates or diluted solutions (e.g. water and methanol) compounds remain isolated and due to the vigorous nature of such evaporation end up in the gas/vapor phase before they can fully react in the liquid phase. With this 'evaporation' the density of the reactive compounds is lowered significantly (factor $\sim 10^{3}$ ) which will result in less polymerization since polymerization has a reaction order higher than one [16]. 
(A)

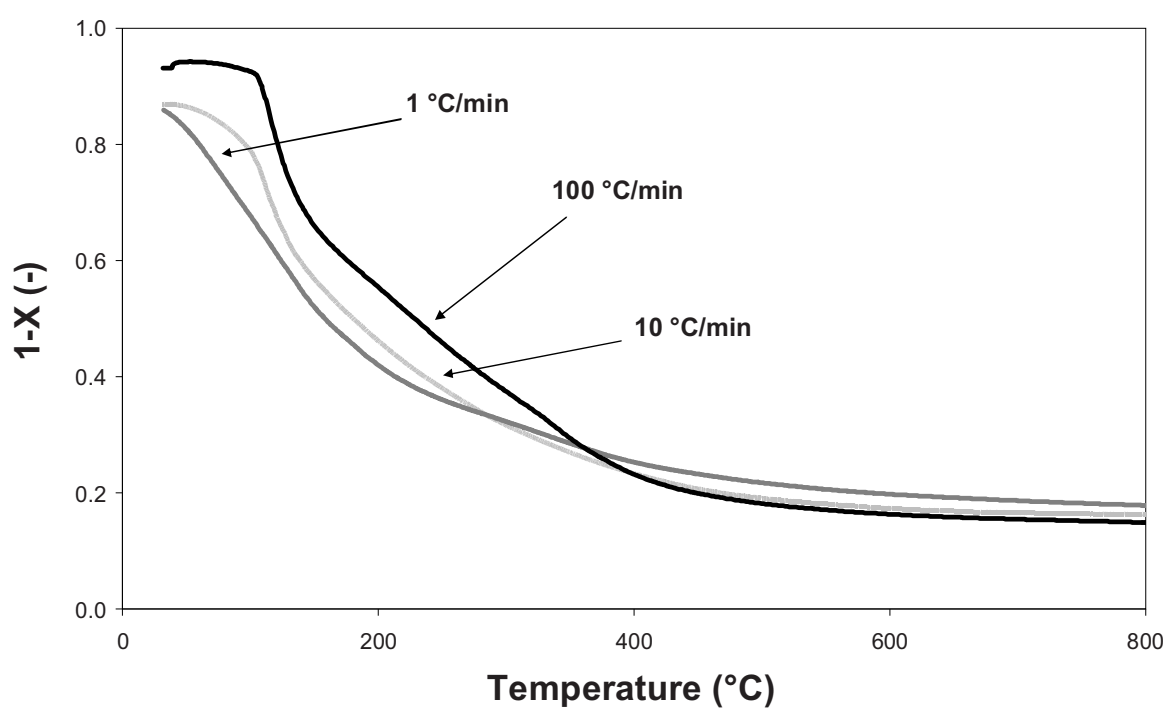

(B)

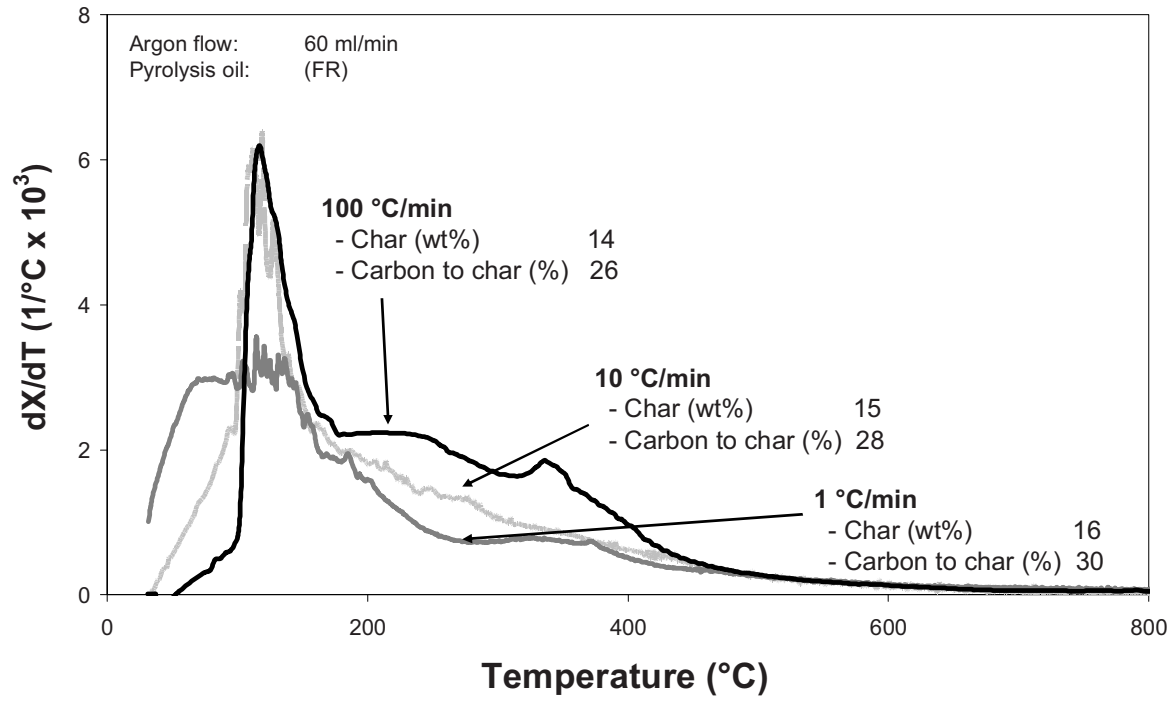


(C)

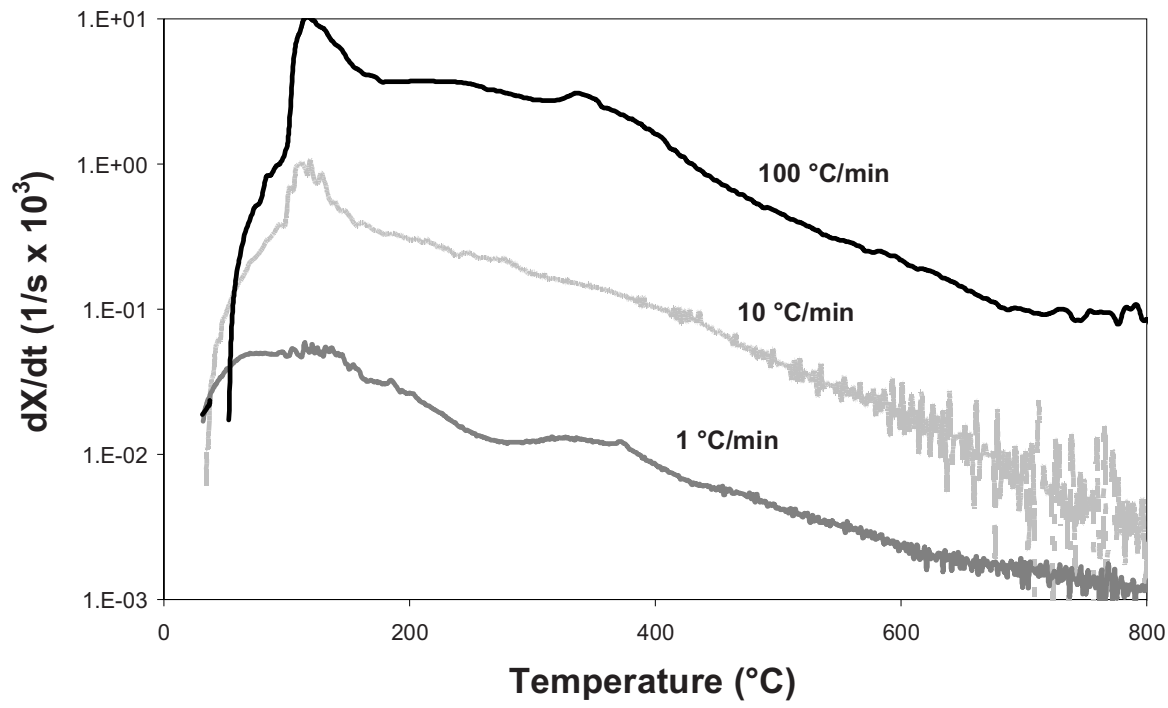

Figure 4.5. Thermogravimetric analysis of pyrolysis oil at different heating rates $(1,10$ and 100

${ }^{\circ} \mathrm{C} / \mathrm{min}$ ) in inert (argon) gas. (A) weight conversion (1-X) versus temperature profile. (B) reaction rate $\mathrm{r}_{\mathrm{wT}}$ (temperature based) versus temperature. (C) reaction rate $\mathrm{r}_{\mathrm{wt}}$ (time based) versus temperature. The reported measured temperatures are of the sample cup, not of the actual liquid inside. $\mathrm{m}_{0}$ is measured with an external balance since some weight loss is being observed during the stabilization time of the TGA; this results in that the starting point is always lower than 1.

Table 4.3. Char productions using TGA of pyrolysis oil and related fractions/compounds. The amounts are given both on weight and carbon to char basis. The sample was heated to $800{ }^{\circ} \mathrm{C}$ with a heating rate of $10^{\circ} \mathrm{C} / \mathrm{min}$ and an argon flow of $60 \mathrm{ml} / \mathrm{min}$.

\begin{tabular}{c|cc}
\hline (\%) & Weight of feed & Carbon to char \\
\hline Pyrolysis oil (FR) & 15 & 28 \\
Aqueous rich phase (FR) & 7 & 24 \\
Aqueous lean phase (FR) & 21 & 33 \\
Wood (PW) & 15 & 25 \\
Pyrolytic lignin (PW) & 43 & 54 \\
Glucose solution (40 wt\%) & 7 & 28
\end{tabular}


Evaporation of Pyrolysis Oil: Product Distribution and Residue Char Analysis

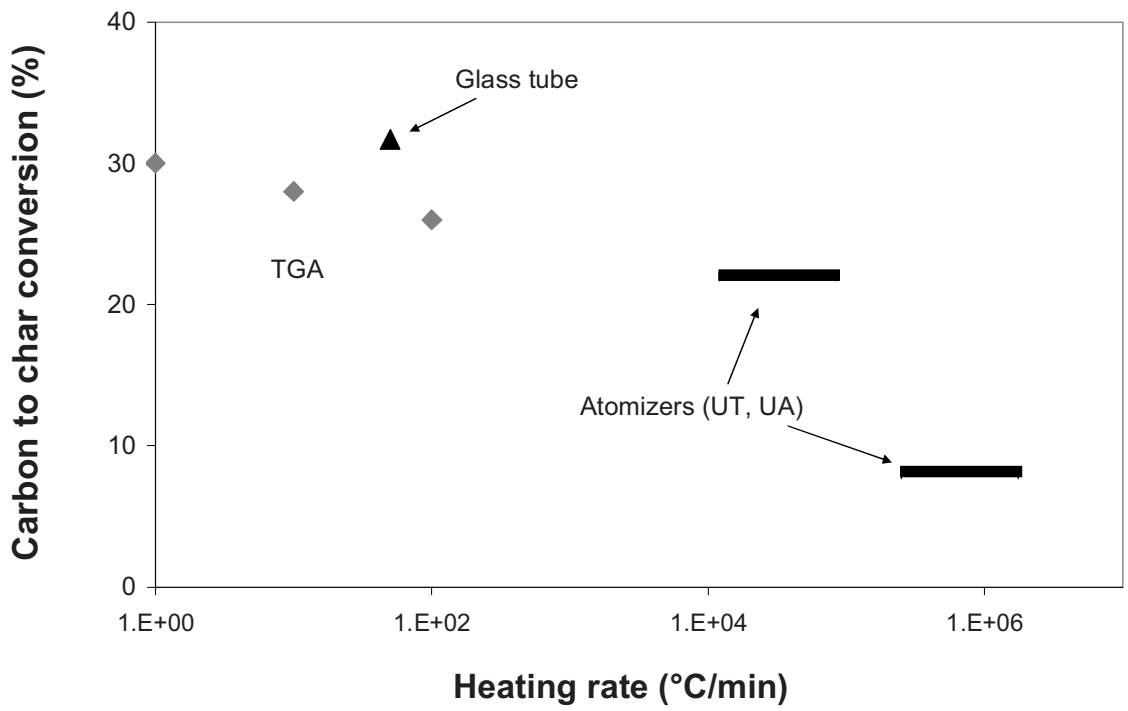

Figure 4.6. Carbon to char conversion of pyrolysis oil versus estimated heating rates of the following equipment: TGA, heated glass tube and droplet evaporation using two different atomizer types (UT and UA).

\subsection{Results char analysis}

\subsubsection{Char combustion}

From the continuous pyrolysis oil evaporation setup, char samples (called pyrolysis oil char) were collected from the installed filter (see Figure 4.1) which were produced at different temperatures and using the two different atomizers. Figure 4.7 shows the combustion experiments done in a TGA when the samples were heated in an air/argon mixture at a constant heating rate of $5{ }^{\circ} \mathrm{C} / \mathrm{min}$. Two different types of carbon containing materials were initially heated to see the difference in the start and the peak of the combustion process (see Figure 4.7A), namely char from fast pyrolysis (wood pyrolysis char) which is known to have a high reactivity and activated carbon which is quite stable char. The difference in combustion peaks is significant; around $500{ }^{\circ} \mathrm{C}$ for wood pyrolysis char and $645{ }^{\circ} \mathrm{C}$ for activated carbon. The collected chars (Figure 4.7B) show reactivities more similar to char from wood fast pyrolysis than from activated carbon. 
This is different to what Branca et al. [17] measured where the pyrolysis oil char reactivities were lower than those of wood pyrolysis char. This difference is most likely due to the different char production methods (cup heating versus atomization). The use of different atomizers shows a slight difference in reactivity where UA (small droplets) is combusted at a lower temperature than UT (big droplets). This is remarkable since with small droplet evaporation, the amount of char being produced is much less and one could think only a lesser reactive fraction would remain. The reactivity is most likely determined by the composition of the char and the accessibility for gases. Besides this the temperature, at which the char has been produced, seems to have an important influence on the activation and peak temperatures. When pyrolysis oil evaporation chars are being produced at high temperatures $\left(\sim 850{ }^{\circ} \mathrm{C}\right)$, they are less reactive. Up till a temperature of $654{ }^{\circ} \mathrm{C}$, the reactivity seems similar. This was also confirmed when chars were produced at different final temperatures (heating rate: $10{ }^{\circ} \mathrm{C} / \mathrm{min}$ ), kept at those temperatures for $15 \mathrm{~min}$, and then cooled down. The reactivity of these chars increase with decreasing final temperature of production as is shown in Figure 4.7C. 
Evaporation of Pyrolysis Oil: Product Distribution and Residue Char Analysis

(A)

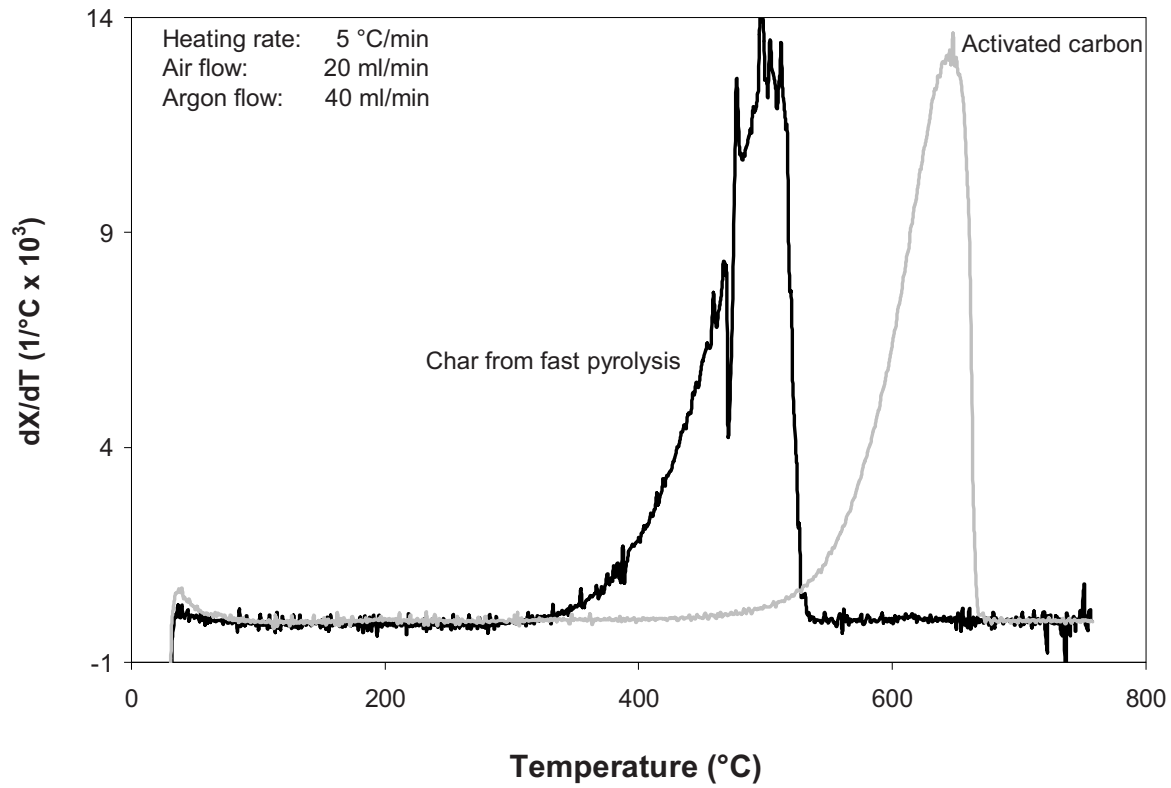

(B)

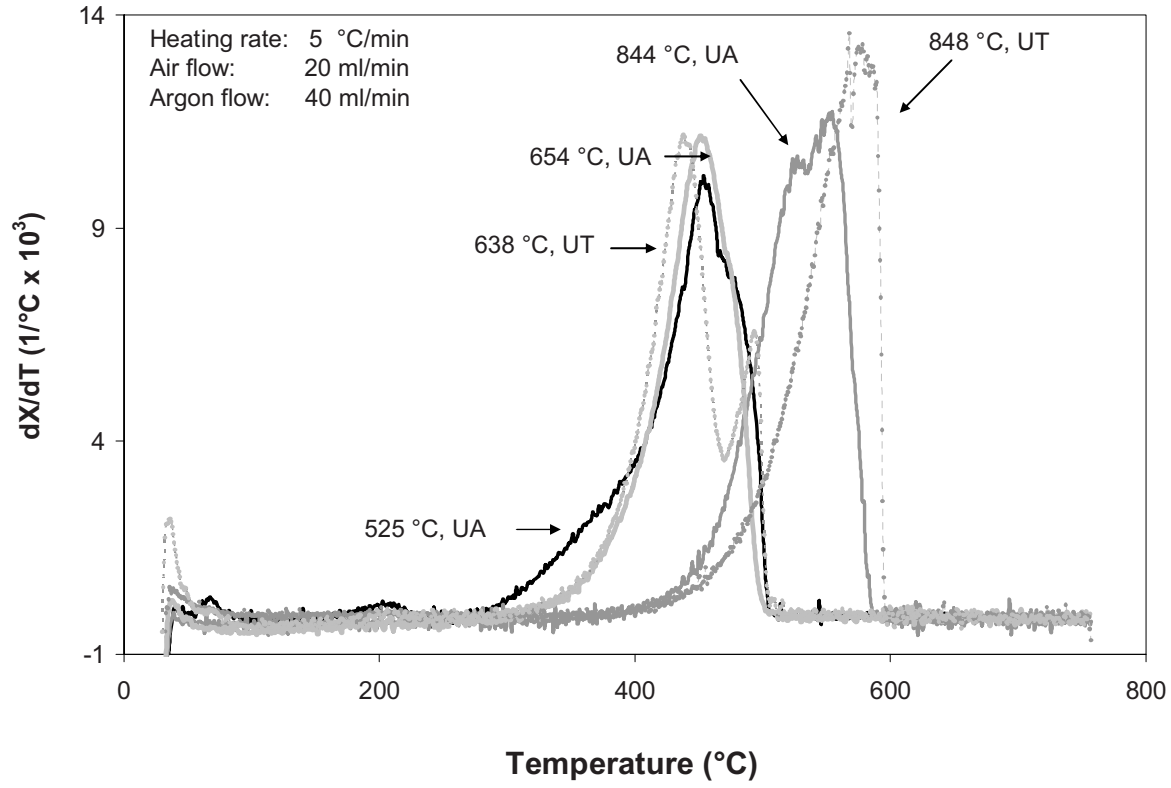


(C)

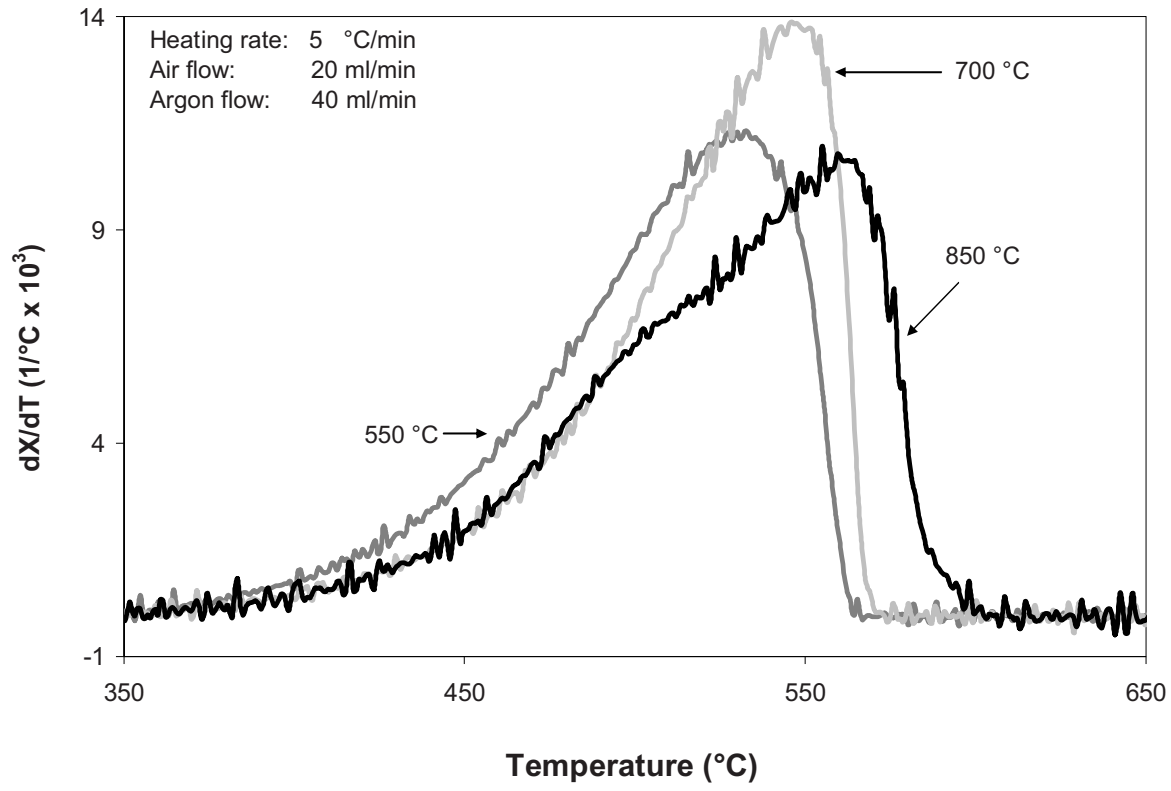

Figure 4.7. Thermogravimetric analysis in an air flow. (A) shows combustion profiles during a constant heating of the sample for char produced during the fast pyrolysis of pine wood and of

activated carbon. (B) shows combustion profiles of chars collected from the continuous evaporation setup which was operated at different temperatures using two different atomizers. (C) shows chars produced at a constant heating rate of $10{ }^{\circ} \mathrm{C} / \mathrm{min}$ and then cured $(15 \mathrm{~min})$ at different peak temperatures $\left(550,700\right.$ and $\left.850^{\circ} \mathrm{C}\right)$.

\subsubsection{Structural analysis of char}

From the chars produced, one was selected for further analysis, namely the pyrolysis oil char produced at $525{ }^{\circ} \mathrm{C}$ with the ultrasonic atomizer (UA, elemental analysis (wt\%): C: 76.7, H: 3.4, Rest: 19.9). This choice was based upon (i) evaporation experiments showed the lowest char yields with this atomizer and (ii) combustion activity measurements showed that this chars is among the most reactive. Figure 4.8 shows Scanning Electron Microscope (SEM) photos of the char. The char shows to be consisting of mostly hollow spheres (wall thickness order magnitude of a few hundred nanometers) which have been ruptured. Onto and into these larger structures, smaller 
particles are deposited. The char is very light/fluffy as compared to char produced during fast pyrolysis of wood. This is believed to be the reason for the high carbon elutriation from an earlier used fluidized bed for steam reforming of pyrolysis oil [3,7,8] (and Chapters 2 and 3). The largest sizes of the spheres (around 100 micron) are in the same size range as the largest pyrolysis oil droplets (88-117 micron) which were photographed with the high speed camera. The spheres seem to be similar to the glassy/cenosphere solids produced during pyrolysis oil evaporation and/or combustion $[13,15]$.

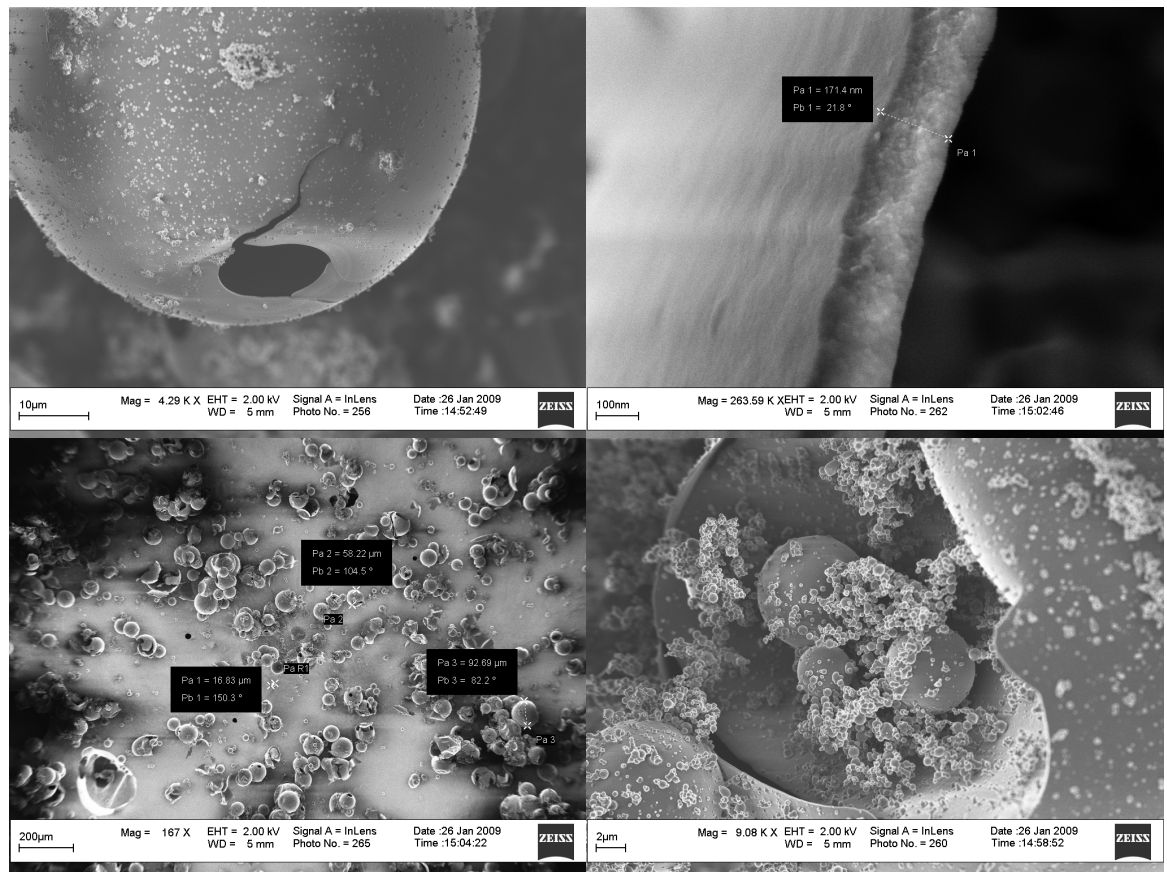

Figure 4.8. SEM photos taken of char from the continuous pyrolysis oil droplet evaporation setup produced at $525^{\circ} \mathrm{C}$ using an ultrasonic atomizer.

\subsubsection{Char steam gasification}

Besides combustion reactivity, the reactivity of char towards steam gasification was also studied. A high surface area is seen using the SEM photos (Figure 4.8) which promises a high reactivity since the steam should be able to penetrate deep into the char structure. Figure 4.9A shows measured reaction rates of the char for steam gasification at a char conversion $(\mathrm{X})$ of 0.3 . The steam gasification was always preceded by some 
devolatilization of the char, which is also expected when looking at TGA pyrolysis oil heating (Figure 4.5B) where above $525{ }^{\circ} \mathrm{C}$ a small but significant amount of solid conversion is attained. At low temperatures $\left(<700{ }^{\circ} \mathrm{C}\right)$ this effect is still significant but at higher temperature it is negligible compared to the steam gasification.

The gasification rate of pyrolysis oil char can be well described with an Arrhenius type of temperature dependence giving an activation energy (Ea) of $274 \mathrm{~kJ} / \mathrm{mol}$ which is at the higher end compared to earlier measured activation energies of steam gasification of biomass originating chars (Ea 105-271 kJ/mol) [18].

The reactivity profiles at the same temperature for pyrolysis oil char, wood pyrolysis char and activated carbon show distinct behavior (Figure 4.9B). The activated carbon shows a constant activity over the whole conversion range measured which can be interpreted as zero order gasification reactivity in char. The pyrolysis oil char and wood pyrolysis char show quite similar profile namely a readily decreasing reactivity with increasing conversion which was also observed by Barrio et al. [18]. The following explanation can be given for this change in reactivity: (i) the reaction order in char is not zero, (ii) there is inhibition (for instance hydrogen and carbon monoxide), (iii) the carbon structure changes/is less accessible which results in an apparent different reaction order, and (iv) the char ages in time leading to less reactive chars. (iii) and (iv) are expected to be dominant in explaining this behavior. The carbon surface structure has been shown on SEM photos to be very complex (Figure 4.8) where big hollow spheres are present which could be assumed to be reacting as a flat plate and smaller deposits which could react away as small porous spheres. This complex structure could lead to a higher initial rate decreasing with increasing conversion. The char has shown 'aging' when it is subjected to elevated temperatures for a certain time (Figure 4.7C and ref [19]) leading to a decreasing reactivity rate. The activated carbon giving its constant reactivity over time is then due to that the overall structure does not change (in the conversion range measured) and does not undergo 'aging' since it was already subjected to higher temperatures during production. 
(A)

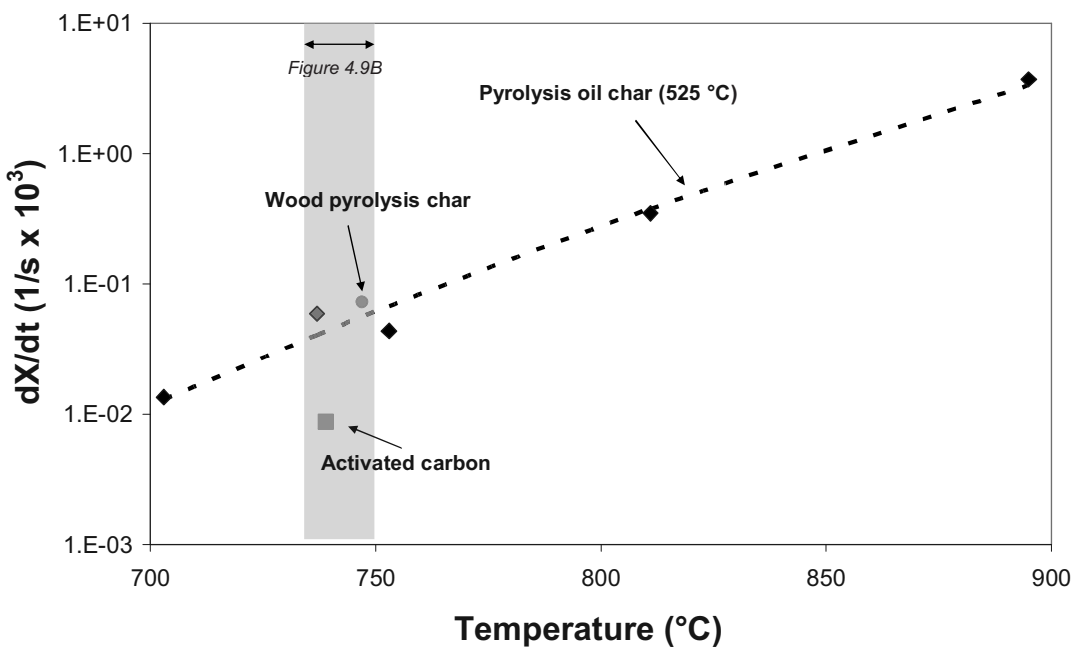

(B)

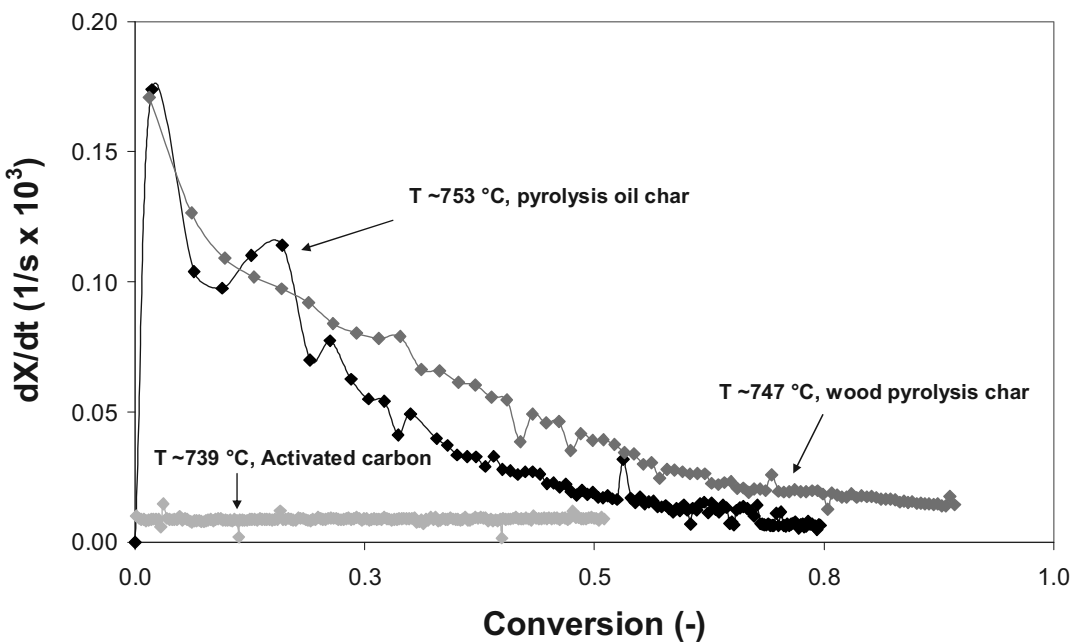

Figure 4.9. (A) Steam gasification rate versus temperature (including devolatilization) of char produced from evaporation of pyrolysis oil at $525^{\circ} \mathrm{C}$ with the ultrasonic atomizer (UA) at a char conversion of $\mathrm{X}=0.3$. The dotted line is the Arrhenius kinetic fit with an Ea of $274 \mathrm{~kJ} / \mathrm{mol}$. The steam gasification rates of wood pyrolysis char and activated carbon are added for comparison. (B) Gasification rate profiles ( $\left.\mathrm{r}_{\mathrm{wt}}\right)$ of pyrolysis oil char, wood pyrolysis char and activated carbon at similar temperatures $\left(\mathrm{T}=739-753{ }^{\circ} \mathrm{C}\right)$. 


\subsection{Mechanism of pyrolysis oil evaporation}

The temperature-time history of a pyrolysis droplet determines not only the amount of char being formed but also its reactivity as is illustrated in Figure 4.10. Our results show that a part of the pyrolysis oil seems to always evaporate, leading to gases and vapors which can be reformed to create syngas. Another part can either be converted to char or similar to the abovementioned route generate gases/vapors which is determined by the heating rate. With higher heating rates the ratio of the rate of polymerization/gasification is lowered. The formed chars show 'aging' behavior when they are exposed to higher temperatures (above $650^{\circ} \mathrm{C}$, see Figure $4.7 \mathrm{~B}$ and $\mathrm{C}$ ). This aging behavior, together with the complex structure of the char, results in steam gasification rates which decrease with increasing extend of conversion.

When the whole evaporation process would be pressurized, the evaporation curve (Figure 4.3 and 4.5 ) is expected to shift to higher temperatures. This will probably lead to more char formation since polymerization rates are higher.

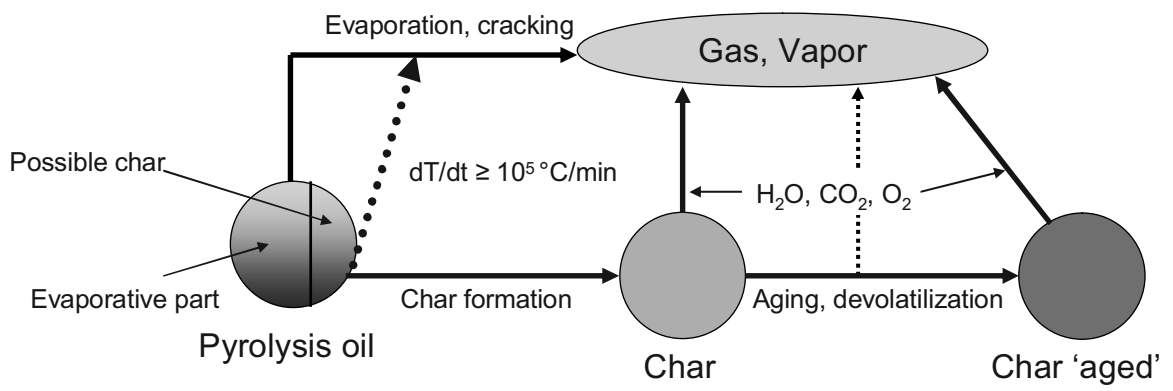

Figure 4.10. Evaporation scheme of pyrolysis oil leading to gases, vapors and char. The formed char can age to form a less reactive char. Both chars can be converted either by gasification (steam and $\mathrm{CO}_{2}$ ) or combustion. The temperature-time trajectory will determine which pathways are more dominant. 


\subsection{Implications for steam reforming of pyrolysis oil}

The presented results have shown that with the evaporation of pyrolysis oil (or its fractions) always char will be formed. This has a large impact on steam reforming process of pyrolysis oil whether single or staged reactor concepts are envisaged. This char amount can be considerable: a maximum of $32 \%$ on carbon basis was obtained using forest residue pyrolysis oil under slow heating conditions. This amount differs with varying types/qualities of pyrolysis oil [7].

Char formation during slow evaporation is much higher than other possible reactions leading to solid carbonaceous species such as coke which can be formed on the steam reforming catalyst (at sufficient high temperatures) and soot formed via vapor cracking. By applying very high heating rates the amount of char formed can be significantly reduced where the underlying mechanism seems to be dilution of the reactive species ( $\sim 10^{3}$ times with evaporation) and/or higher gasification rates of char precursors relative to polymerization. Specially designed atomizers create very small droplets which can be evaporated quickly. The speed of evaporation can be further increased with the use of a fluidized bed which has excellent heat transfer properties. However, not only the amount of char is important but also in which form it is being created. Droplet evaporation in a heated empty space leaves a very light/fluffy char residue which easily elutriates from the reactor before it can be converted.

It is therefore necessary to bind the char to a carrier. Sand [3] has shown to not have enough binding capacity (fluidization scrapes char of its surface) and therefore more porous materials are probably preferred so that char formation takes place inside the carrier. How to contact the pyrolysis oil to such a carrier is not yet straightforward and has to be investigated further. The initial high temperature difference between the droplet and the carrier can limit the effectiveness of contacting. The Leidenfrost effect (which was shown to occur with large pyrolysis oil droplets on a hot surface) can let droplets bounce off the carrier and it has to be investigated what would be the ideal oil/carrier particle diameter ratio: a high ratio will cool down the carrier which then would allow carrier soaking and a low ratio would instantly heat the oil. Another option could be to modify the shape of the steam/dry reforming catalyst in such a way that residual char which elutriates from the fluidized bed is bound to it in the secondary reactor. In this way 
the char could get sufficient residence time to react. Preliminary tests in a bubbling fluidized with a more porous bed material have shown higher carbon to gas conversions as compared to 'inert' sand [20].

The char itself has combustion and gasification properties comparable to other biomass originated chars. When pyrolysis oil steam/dry reforming is considered, the char can be combusted to supply heat for the endothermic reforming reactions and evaporation. However, direct internal gasification of the char is preferred from an efficiency and process operation point of view [7]. Current steam gasification tests have shown that at the preferred temperature regime $\left(<700{ }^{\circ} \mathrm{C}\right)$ for operating a fluidized bed for evaporation, the rate of char conversion is too low. Higher operating pressures will probably enhance this conversion rate but catalytic active materials (Chapter 5) seem to be necessary to change char gasification conversion times from hours to minutes.

\subsection{Conclusions}

Pyrolysis oil (and all its fractions) evaporation is always coupled with the formation of char which is formed via polymerization reactions. The speed through which the pyrolysis oil liquid goes through the $100-350{ }^{\circ} \mathrm{C}$ temperature zone determines the total amount of char that is formed. Very high heating rates $\left(\geq 10^{5}{ }^{\circ} \mathrm{C} / \mathrm{min}\right)$ which can be achieved with small droplets lead to much less char ( $8 \%$, carbon basis) than the 'maximum' amount ( $\sim 30 \%$, carbon basis) which is measured with analytical heating equipment like TGA.

Char from pyrolysis oil evaporation has a very open structure and it consists out of large hollow spheres onto which smaller particles are being deposited. The char has reactivities towards combustion and steam gasification comparable to char formed during the pyrolysis of biomass. The char shows aging behavior when subjected to higher temperatures $\left(\geq 650-700^{\circ} \mathrm{C}\right)$. 


\section{References}

1. De Miguel Mercader, F.; Ardiyanti, A.; Gutierrez, A.; Khromova, S.; Leijenhorst, E.; Kersten, S. R. A.; Hogendoorn, J. A.; Prins, W.; Groeneveld, M. J. Upgrading of bioliquids for co-processing in standard refinery units. Proceedings of the 16th European Biomass Conference and Exhibition, Valencia, Spain, June 2-6, 2008, 2103.

2. Corma, A.; Huber, G.W.; Sauvanaud, L.; O’Conner, P. Processing biomass-derived oxygenates in the oil refinery: Catalytic cracking (FCC) reaction pathways and role of catalyst. J. Catal. 2007, 247, 307.

3. Van Rossum, G.; Kersten, S.R.A.; Van Swaaij, W.P.M. Catalytic and Noncatalytic Gasification of Pyrolysis Oil. Ind. Eng. Chem. Res. 2007, 46, 3959.

4. Czernik, S.; French, R.; Feik, C.: Chornet, E. Hydrogen by Catalytic Steam Reforming of Liquid Byproducts from Biomass Thermoconversion Processes. Ind. Eng. Chem. Res. $2002,41,4209$.

5. Kechagiopoulos, P.N.; Voutetakis, S.S.; Lemonidou, A.A.; Vasalos, I.A. Hydrogen Production via Reforming of the Aqueous Phase of Bio-Oil over Ni/Olivine Catalysts in a Spouted Bed Reactor. Ind. Eng. Chem. Res. 2009, 48, 1400

6. Medrano, J.A.; Oliva, M.; Ruiz, J.; Garcia, L.; Arauzo, J. Hydrogen from biomass pyrolysis liquids. Catalytic steam reforming in fluidized bed reactor with $\mathrm{Ni} / \mathrm{Mg}-\mathrm{Al}$ catalysts. Proceedings of the 16th European Biomass Conference and Exhibition, Valencia, Spain, June 2-6, 2008, 2158.

7. Van Rossum, G.; Kersten, S.R.A.; Van Swaaij, W.P.M. Staged gasification/steam reforming of pyrolysis oil. Ind. Eng. Chem. Res. 2009, 48, 5857.

8. Van Rossum, G.; Potic, B.; Kersten, S.R.A.; Van Swaaij, W.P.M. Catalytic gasification of dry and wet biomass. Catal. Today 2008, 145, 10. 
9. Oasmaa, A.; Sipilä, K.; Solantausta, Y.; Kuoppala, E. Quality Improvement of Pyrolysis Liquid: Effect of Light Volatiles on the Stability of Pyrolysis Liquids. Energy \& Fuels $2005,19,2556$.

10. Scholze, B.; Meier, D. Characterization of the water-insoluble fraction from pyrolysis oil (pyrolytic lignin). Part I. PY-GC/MS, FTIR, and functional groups. J. Anal. Pyrolysis $2001,60,41$.

11. Scholze, B.; Hanse, C.; Meier, D. Characterization of the water-insoluble fraction from pyrolysis liquids (pyrolytic lignin). Part II. GPC, carbonyl groups, and ${ }^{13} \mathrm{C}-\mathrm{NMR}$. J. Anal. Pyrolysis 2001, 58-59, 387.

12. Branca, C.; Di Blasi, C. Multistep Mechanism for the Devolatilization of Biomass Fast Pyrolysis Oils. Ind. Eng. Chem. Res. 2006, 45, 5891.

13. Wornat, M.J.; Porter, B.G.; Yang, N.Y.C. Single Droplet Combustion of Biomass Pyrolysis Oils. Energy \& Fuels 1994, 8, 1131.

14. Hallett, W.L.H.; Clark, N.A. A model for the evaporation of biomass pyrolysis oil droplets. Fuel 2006, 85, 532.

15. García Pérez, M.; Lappas, P.; Hughes, P.; Dell, L.; Chaala, A.; Kretschmer, D.; Roy, C. Evaporation and Combustion Characteristics of Biomass Vacuum Pyrolysis Oils. IFRF Combustion Journal 2006, 200601.

16. Knežević, D.; Van Swaaij, W.P.M.; Kersten, S.R.A. Hydrothermal Conversion of Biomass: I, Glucose Conversion in Hot Compressed Water. Ind. Eng. Chem. Res. 2009, 48,4731 .

17. Branca, C.; Di Blasi, C.; Elefante, R. Devolatilization and Heterogeneous Combustion of Wood Fast Pyrolysis Oils. Ind. Eng. Chem. Res. 2005, 44, 799. 


\section{Evaporation of Pyrolysis Oil: Product Distribution and Residue Char Analysis}

18. Barrio, M.; Gøbel, B.; Risnes, H.; Henriksen, U.; Hustad, J.E.; Sørensen, L.H. Steam gasification of wood char and the effect of hydrogen inhibition on the chemical kinetics. Progress in thermochemical biomass conversion: Volume 1, Bridgwater, A.V., MPG Books Ltd: Cornwall, U.K., 2001, 32.

19. Chen, G.; Yu, Q.; Sjőstrőm, K. Reactivity of char from pyrolysis of birch wood. J. Anal. Appl. Pyrolysis 1997, 40-41, 491.

20.

Bleeker, M.F.; Veringa, H.J.; Kersten, S.R.A. Production of hydrogen with the steam-iron process using pyrolysis oil. Ind. Eng. Chem. Res. 2009, submitted. 


\title{
Chapter 5
}

\author{
Design of Efficient Catalysts for Gasification \\ of Pyrolysis Oil Char
}

\begin{abstract}
The catalytic performance of a ceria-zirconia based catalyst for (i) steam/ $\mathrm{CO}_{2}$ gasification and (ii) combustion of char produced during pyrolysis oil evaporation was investigated and compared with the noncatalytic scenario in the temperature range $600-800{ }^{\circ} \mathrm{C}$. Kinetic studies revealed that the presence of the ceria-zirconia catalyst enhanced char gasification rates significantly, up to one order of magnitude at $800{ }^{\circ} \mathrm{C}$, for both steam and $\mathrm{CO}_{2}$ gasification. It is suggested that the red-ox properties of the ceria-zirconia catalyst play a significant role in char gasification, by allowing oxygen mobility and activation of $\mathrm{H}_{2} \mathrm{O}$ and $\mathrm{CO}_{2}$. Furthermore, XPS and SEM characterization studies showed that the catalyst also influences the nature of char formed during pyrolysis oil evaporation to a great extent, by forming oxygenated species which are expected to be more reactive.
\end{abstract}

A manuscript based on this Chapter has been submitted to Fuel. 


\subsection{Introduction}

Biomass has recently received considerable attention as a potential sustainable feedstock for hydrogen production, as it would strongly contribute to the minimization of green house emissions. In the context of biomass, flash pyrolysis of lignocelluloses results in liquid pyrolysis oil. This makes it a convenient feedstock for storage, transport and processing as compared to the bulk biomass [1]. Catalytic steam reforming of pyrolysis oil is a promising option for hydrogen production. This reaction is carried out at high temperatures $\left(>800{ }^{\circ} \mathrm{C}\right)$ [2]. Therefore, pyrolysis oil needs to be evaporated and heated to the desired reaction temperature. The instability of pyrolysis oil at these high temperatures due to polymerization reactions results in carbonaceous solid residues, besides gases and vapors. These solid residues are referred to as homogeneous char. We have shown earlier and concluded [3] (Chapter 4) that formation of these carbonaceous deposits during pyrolysis oil evaporation cannot be avoided completely. These carbonaceous species can be detrimental to catalyst activity/stability and affect the efficiency of the overall reforming process [4].

Decoupling of (i) pyrolysis oil evaporation and (ii) reforming of the generated gases/vapors using a two staged reactor concept (fluidized bed for evaporation + fixed bed for steam reforming) has been reported [5] to successfully improve steam reforming catalyst stability and improve the process. Contact between char and reforming catalyst can be avoided if char is retained and converted in the fluidized bed itself and a catalyst is essential for this [4]. Steam and $\mathrm{CO}_{2}$ gasification are promising routes to enhance char removal during pyrolysis oil evaporation [4], producing at the same time a high value gas product (syngas). Pyrolysis oil is being evaporated at around $700{ }^{\circ} \mathrm{C}$ and at these low temperatures a catalyst is essential to achieve the required char gasification.

The envisioned downstream processes determine the preference for steam or $\mathrm{CO}_{2}$ as gasification agent. Steam gasification is used to produce a hydrogen-rich gas product. On the contrary, combined steam and $\mathrm{CO}_{2}$ gasification is applied when the end application requires adjustment of the $\mathrm{H}_{2} / \mathrm{CO}$ ratio to lower values (around 2-3, e.g. for methanol synthesis and Fischer-Tropsch process).

In the case that $\mathrm{CO}_{2}$ and/or steam gasification of char are insufficient for the required levels of char removal, an external partial combustion step (e.g. via a circulating fluidized 
bed) is required. The heat released during this exothermic combustion can be integrated to (i) pyrolysis oil evaporation or (ii) the endothermic reforming step. The circulation of char (solid) at high pressures (10-30 bar) is the main challenge, as it results in difficult process operability.

There are parallels to be drawn between char and coal gasification, as the challenges are very similar. Exhaustive work on coal gasification [6,7] has shown that alkali metal compounds are effective catalysts for steam gasification of coal. Alkali metals are suggested to enhance gasification activity by assisting in the formation of $\mathrm{OH}$ groups $[8,9]$. In the well known Exxon Catalytic Coal Gasification (CCG) process, for instance, $\mathrm{K}_{2} \mathrm{CO}_{3}$ was used as catalyst. This allowed reaction temperatures as low as $650-750{ }^{\circ} \mathrm{C}$. Similarly, enhanced gasification activity by alkali/alkaline earth based catalysts has been reported also for $\mathrm{CO}_{2}$ gasification of coal $[7,10,11]$. In comparison to steam gasification, $\mathrm{CO}_{2}$ gasification is carried out at higher temperatures even in the presence of a catalyst $\left(750-900{ }^{\circ} \mathrm{C}\right)$.

The most widely reported coal gasification catalyst, $\mathrm{K}_{2} \mathrm{CO}_{3}$, however, presents quite a few problems. First of all, catalyst losses occur during gasification due to the formation of volatile $\mathrm{KOH}$ species. Secondly, interaction of catalyst with minerals present in coal leads to the formation of inactive and water insoluble compounds (e.g. potassium aluminum-silicates) from which recovery of the catalyst is difficult $[10,11]$. These catalyst losses make the gasification process uneconomic. Furthermore, it has been reported by Marshall and Smits [12] that potassium promotes the methanation reaction, which is favored at high pressure and low temperature (industrial desired conditions) and undesired in our case as part of the syngas would be consumed. Therefore, an alternative catalyst which has the ability to activate $\mathrm{H}_{2} \mathrm{O}$ and $\mathrm{CO}_{2}$ and avoiding the abovementioned problems is desired for minimizing the problems related to homogeneous char formation during pyrolysis oil gasification. Tomisighe et al. [13] observed that $\mathrm{CeO}_{2}$ supported catalysts (e.g. $\mathrm{Rh} / \mathrm{CeO}_{2} / \mathrm{SiO}_{2}$ ) with the ability to activate both water and $\mathrm{CO}_{2}[14,15]$, exhibited good activity in cellulose gasification. Ceria-based catalysts may thus be a good option for the steam and $\mathrm{CO}_{2}$ gasification of char formed during pyrolysis oil evaporation.

The contact between catalyst and char is a crucial step in the gasification process, as it influences the catalytic activity to a large extent. In the case of coal gasification, a 
solution containing the catalyst precursor is sprayed on coal prior to gasification. In the case of pyrolysis oil, this approach cannot be applied since evaporation of pyrolysis oil is required previous to gasification. Instead, pyrolysis oil is sprayed on the catalyst particles in the gasification unit itself.

The aim of the present Chapter is to develop an active and stable ceria catalyst for the (i) steam $/ \mathrm{CO}_{2}$ gasification and (ii) combustion of char formed during pyrolysis oil evaporation. Additionally, we aim at exploring and understanding whether the presence of catalyst has any influence on the nature of char formed during the pyrolysis oil evaporation, which would in turn influence the reactivity/kinetics of gasification.

\subsection{Experimental}

\subsubsection{Catalyst preparation}

Ceria catalysts were prepared using the wet impregnation technique. Yttrium stabilized zirconia (TOSOH, TZ-8Y) was first calcined for $15 \mathrm{~h}$ at $850{ }^{\circ} \mathrm{C}$ (heating rate $\left.5{ }^{\circ} \mathrm{C} / \mathrm{min}\right)$ in flowing air $(30 \mathrm{ml} / \mathrm{min})$. The powder was then impregnated with an aqueous solution of $\mathrm{Ce}\left(\mathrm{NO}_{3}\right)_{3} \cdot 6 \mathrm{H}_{2} \mathrm{O}$ (Fuka) to yield a catalyst with $8.2 \%$ ceria loading. The $\mathrm{Ce}\left(\mathrm{NO}_{3}\right)_{3} \cdot 6 \mathrm{H}_{2} \mathrm{O}$ solution was mixed for $2 \mathrm{~h}$ and then dried at $50{ }^{\circ} \mathrm{C}$ in vacuum for $4 \mathrm{~h}$ in a rotary evaporator. Subsequently, the impregnated catalyst was first calcined at $700{ }^{\circ} \mathrm{C}$ (heating rate $5{ }^{\circ} \mathrm{C} / \mathrm{min}$ ) for $6 \mathrm{~h}$ and then crushed and sieved to give grains of $0.3-0.6 \mathrm{~mm}$. This catalyst will be, hereafter, denoted as Ce-Zr-O.

\subsubsection{Materials}

The pyrolysis oil was produced in the Process Development Unit of VTT (Finland) from forest residue [16].

For noncatalytic experiments, finely powdered char, produced at $525{ }^{\circ} \mathrm{C}$, was used. Char production is described in detail in Chapter 4. This char will be, hereafter, denoted as external char. 


\subsubsection{Contact between char and catalyst}

The contact between char and catalyst will depend on the type of catalyst and the contacting efficiency in a fluidized bed. In order to verify the relevance of such contact, two extreme situations have been tested in this work: (i) absorption of the oil into the catalyst particles and subsequent heating to produce char in-situ in the pores of the catalyst, resulting in optimal contact and (ii) physical mixing of char, produced externally, with the catalyst particles in a mortar leading to poor (interparticle) contact.

The preparation procedure for (i) was the following: approximately $40 \mathrm{mg}$ of Ce- $\mathrm{Zr}-\mathrm{O}$ or $\mathrm{SiO}_{2}$ as an inert, reference material [17], (Aerosil 380, Degussa) was impregnated with pyrolysis oil (15-20 mg) in a small crucible. Subsequently, the impregnated catalyst was first heated up to $800{ }^{\circ} \mathrm{C}\left(10^{\circ} \mathrm{C} / \mathrm{min}\right)$ in flowing argon $(60 \mathrm{ml} / \mathrm{min})$ and then cooled down to room temperature under the same atmosphere. This char will be, hereafter, referred as internal char. For (ii), finely powdered char (denoted as external char) was physically mixed manually in a mortar with known amounts of catalyst. This char will be, hereafter, denoted as physical mix char.

\subsubsection{Catalyst and char characterizations}

Catalyst composition was determined with X-ray fluorescence spectroscopy (XRF) (Phillips PW 1480 spectrometer). Char composition was determined by elemental analysis.

BET specific surface area and porosity were measured with nitrogen adsorptiondesorption at $-196{ }^{\circ} \mathrm{C}$ in a Micromeritics TriStar instrument. The samples were first degassed at $300{ }^{\circ} \mathrm{C}$ in nitrogen

X-Ray photoelectron spectra (XPS) were recorded on a Physical Electronics Quantera XPS system using a monochromatic Al K $\alpha(1486.6 \mathrm{eV}) \mathrm{X}$-ray source operated at 24W (beam diameter $100 \mu \mathrm{m}$ ) with charge neutralization. Survey scans were collected from $-5 \mathrm{eV}$ to $1345 \mathrm{eV}$ with a pass energy equal to $224 \mathrm{eV}$ and $0.8 \mathrm{eV}$ step size. All scans were taken at a $45^{\circ}$ tilt angle. The pressure inside the chamber remained $<3 \cdot 10^{-12}$ bar. Peak shape fitting was performed with Gaussian-Lorentzian sum function and Shirley background subtraction [18] with constraints applied to full width, half maximum (FWHM) values. All binding energies were referenced against a main C (1s) peak at $285.0 \mathrm{eV}$. 
Scanning Electron Microscope (SEM) images were obtained using a LEO 1550 instrument.

\subsubsection{Reactivity measurements}

$\mathrm{CO}_{2}$ gasification experiments were performed in a Mettler Toledo thermogravimetric analyzer (TGA) equipped with good temperature control $\left( \pm 0.7^{\circ} \mathrm{C}\right)$ and a balance $(1 \mu \mathrm{g}$ sensitivity). Experiments were performed isothermally in the temperature range 600-900 ${ }^{\circ} \mathrm{C}$ in a small crucible. Samples were heated rapidly $\left(\sim 150{ }^{\circ} \mathrm{C} / \mathrm{min}\right)$ to the desired temperature in a mixture of carbon dioxide $(20 \mathrm{ml} / \mathrm{min})$ and $\operatorname{argon}(40 \mathrm{ml} / \mathrm{min})$. All experiments were carried out until char conversion was completed or reached steady values. Additional to the TGA balance, the samples weight loss was quantified with a very accurate external balance $(0.01 \mu \mathrm{g}$ sensitivity).

Combustion experiments were performed in the same system. The samples were heated up to $800{ }^{\circ} \mathrm{C}$ at $5{ }^{\circ} \mathrm{C} / \mathrm{min}$ in a mixture of air $(20 \mathrm{ml} / \mathrm{min})$ and argon $(40 \mathrm{ml} / \mathrm{min})$. The initial and final weights of samples were also quantified with the same external balance. It is noteworthy to mention that isothermal experiments were not done for combustion experiments as reaction would have occurred to a too large extent during heating up.

Steam gasification experiments were carried out in a fixed bed reactor. A quartz tube (diameter $45 \mathrm{~mm}$, length $400 \mathrm{~mm}$ ) was used which was placed inside an electrically heated oven. A steam generator was used to create a constant steam flow $\left(300{ }^{\circ} \mathrm{C}\right.$, 0.15-0.5 g/min) and preheated nitrogen (ca. $200{ }^{\circ} \mathrm{C}, 9 \mathrm{ml} / \mathrm{min}$ ) was added as an internal standard. The amount of steam added compared to the char sample (ca. 4-10 mg) was high enough that zero conversion of steam could be assumed. Samples were placed at the end of the oven to ensure adequate preheating of the steam/nitrogen and isothermal gasification. The samples containing char only were premixed with quartz (ca. $150 \mathrm{mg}$ ) to minimize the pressure drop which was created due to the fine structure of the char. However some pressure drop (0.2-0.5 bar) over the sample was observed. For the samples containing char and catalyst ( $9 \mathrm{mg}$ of char $+55 \mathrm{mg} \mathrm{Ce}-\mathrm{Zr}-\mathrm{O}$ ) no quartz was used. The maximum pressure drop observed in this case was 0.3 bar. The reactor outlet was cooled to $\sim 15{ }^{\circ} \mathrm{C}$ and the steam was condensed out completely. A micro-GC (Varian CP-4900) was used to analyze the gas composition. 


\subsubsection{Definitions and reaction equations}

The degree of conversion, $X(t)$, is obtained in this study from the following expression, $X=\left(m_{0}-m_{t}\right) / m_{0} ;(-)$, where $m_{t}$ is the char mass at a certain time $t$ and $m_{0}$ represents the char mass at the beginning of the gasification. The rate of gasification is here defined as the change of conversion over a time period, $r_{w t}=d X / d t ;(1 / \mathrm{s})$. The rate of combustion is here defined as the change of conversion over a temperature range $r_{w T}=d X / d T ;\left(1 /{ }^{\circ} \mathrm{C}\right)$

The reaction equations involved in char gasification and combustion are:

$$
\begin{array}{ll}
\mathrm{C}_{x} \mathrm{H}_{y} \mathrm{O}_{z(s)}+(x-z) \mathrm{H}_{2} \mathrm{O} \rightarrow x \mathrm{CO}+\left(\frac{y}{2}+x-z\right) \mathrm{H}_{2} & \text { steam gasification } \\
\mathrm{C}_{x} \mathrm{H}_{y} \mathrm{O}_{z(s)}+(x-z) \mathrm{CO}_{2} \rightarrow(2 x-z) \mathrm{CO}+\frac{y}{2} \mathrm{H}_{2} & \mathrm{CO}_{2} \text { gasification } \\
\mathrm{C}_{x} \mathrm{H}_{y} \mathrm{O}_{z(s)}+\left(\frac{y}{4}+x-\frac{z}{2}\right) \mathrm{O}_{2} \rightarrow x \mathrm{CO}_{2}+\frac{y}{2} \mathrm{H}_{2} \mathrm{O} & \text { combustion } \\
\mathrm{CO}+\mathrm{H}_{2} \mathrm{O} \leftrightarrow \mathrm{CO}_{2}+\mathrm{H}_{2} & \text { water-gas shift }
\end{array}
$$

\subsection{Results}

\subsubsection{Catalysts characterization}

The ceria content in the catalyst was $8.2 \mathrm{wt} \%$, in the range intended for preparation. Specific surface areas for $\mathrm{Ce}-\mathrm{Zr}-\mathrm{O}$ and $\mathrm{SiO}_{2}$ powders after calcination at $700{ }^{\circ} \mathrm{C}$ were $18 \mathrm{~m}^{2} / \mathrm{g}$ and $351 \mathrm{~m}^{2} / \mathrm{g}$, respectively. The nitrogen sorption isotherm and the pore volume distribution (inset) for the $\mathrm{Ce}-\mathrm{Zr}-\mathrm{O}$ catalyst are shown in Figure 5.1. The isotherm, assigned to Types II \& IV [19], was typical for particles which either are nonporous or possess macropores and relatively low external surface areas. Figure 5.1 (inset) also shows that $\mathrm{Ce}-\mathrm{Zr}-\mathrm{O}$ presented a broad pore distribution, with a mean pore diameter $\sim 50 \mathrm{~nm}$ 


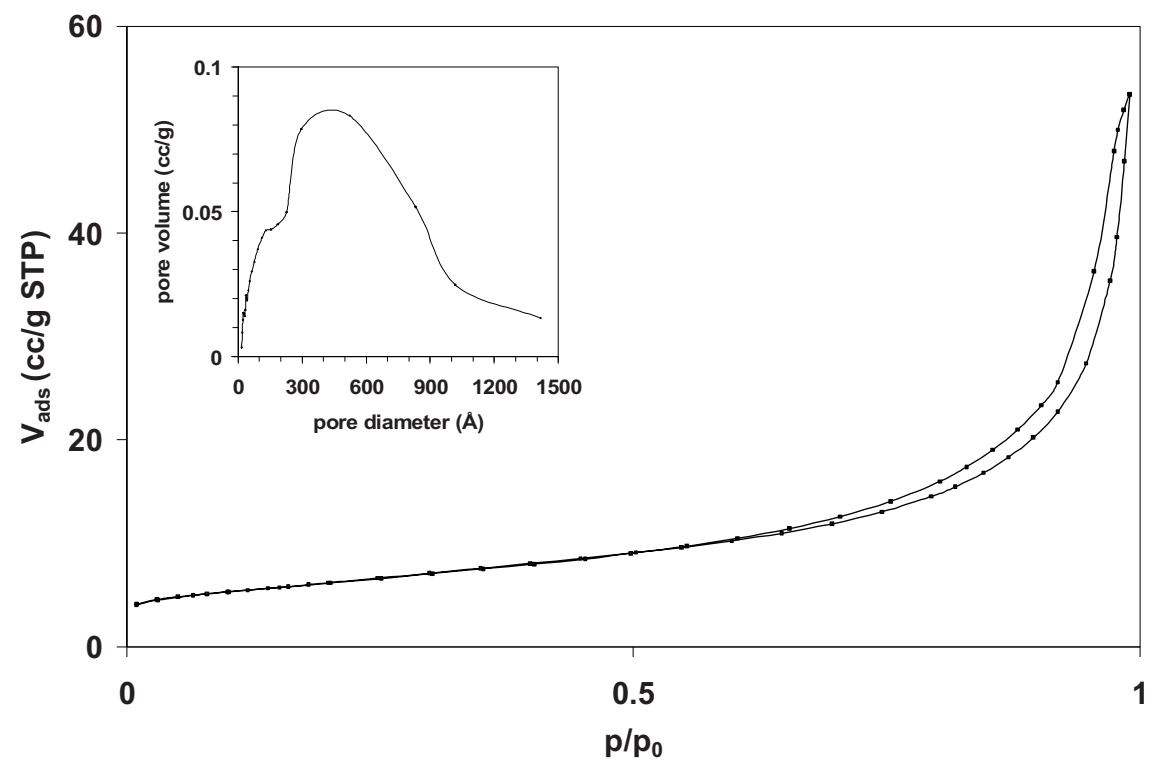

Figure 5.1. Nitrogen adsorption isotherm and pore volume distribution (inset) of Ce-Zr-O after calcination at $700{ }^{\circ} \mathrm{C}$.

\subsubsection{Composition of pyrolysis oil and external char}

The carbon and hydrogen content in the pyrolysis oil were $40.6 \mathrm{wt} \%$ and $7.6 \mathrm{wt} \%$ respectively. The rest $(51.8 \mathrm{wt} \%)$ was mainly oxygen and small amounts of other components, e.g. sulfur, nitrogen and ash. Char produced externally consisted of $76.7 \mathrm{wt} \%$ carbon, $3.4 \mathrm{wt} \%$ hydrogen and $19.9 \mathrm{wt} \%$ oxygen.

\subsubsection{Characterization of internal char deposited on Ce-Zr-O}

Figure 5.2 illustrates char formed during pyrolysis oil evaporation in the presence of Ce-Zr-O. A typical SEM photograph of the cross-section of a catalyst particle with internal char is shown in Figure 5.2A. A zoomed in image of the cross-section (Figure 5.2B) reveals that char formed during pyrolysis oil evaporation was evenly distributed in the catalyst (dark spots are carbon), filling the catalyst pores. An energy dispersive X-ray spectroscopy (EDX) analysis of this section (Figure 5.2C) confirms the presence of carbon and thus, char. 

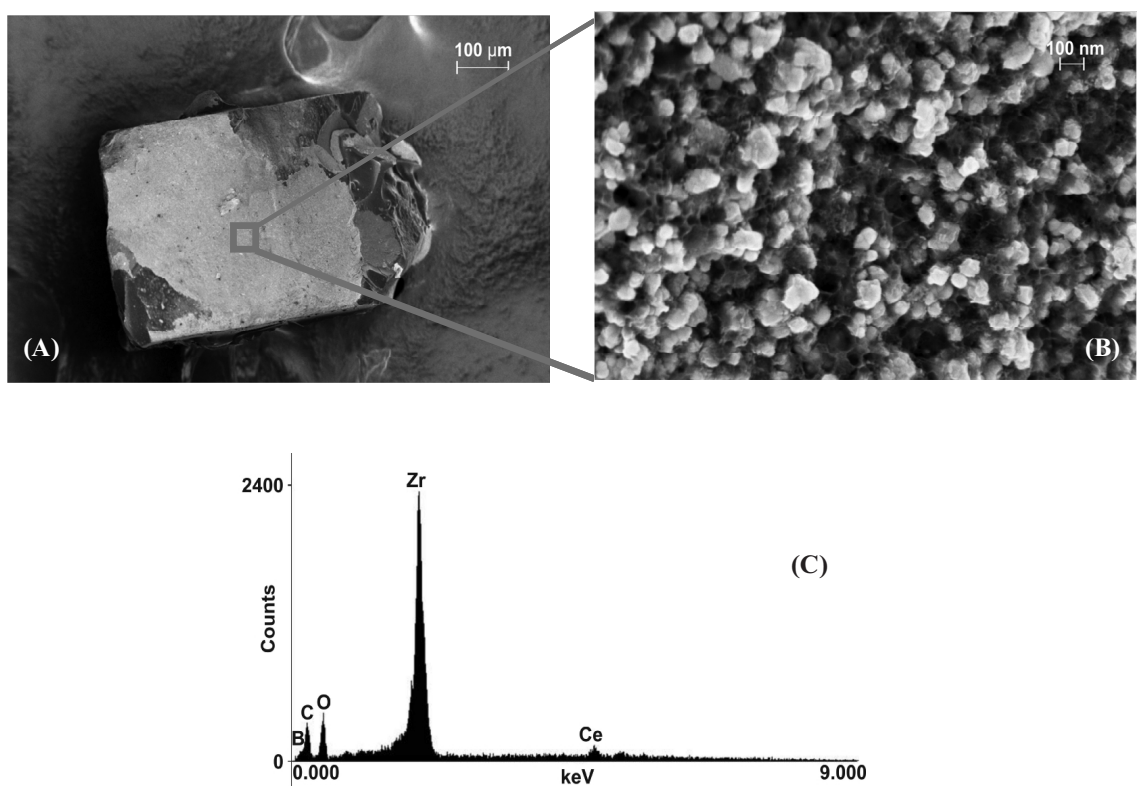

Figure 5.2. Cross-sectional SEM images on a cut catalyst particle of internal char deposited on Ce-Zr-O, (A) Low magnification and (B) high magnification. (C) EDX analysis of a selected area. The light area is the cross section.

Figure 5.3A shows a typical tilted top-view SEM image of internal char deposited on a catalyst particle. EDX analysis (Figure 5.3B) indicates that these deposits were mainly composed of char. As seen, char was not exclusively located in the catalyst pores. A small amount of char formed an external thin surface layer. As shown in Figure 5.3C (cross-section), this external deposits layer was only few $\mu \mathrm{m}$ thick (up to $5 \mu \mathrm{m}$ ). Considering that catalyst particles size is in the range $300-600 \mu \mathrm{m}$, the volume of the external deposits layer is equivalent to a very small fraction of the volume of a catalyst particle $(\sim 2.5 \%)$. 

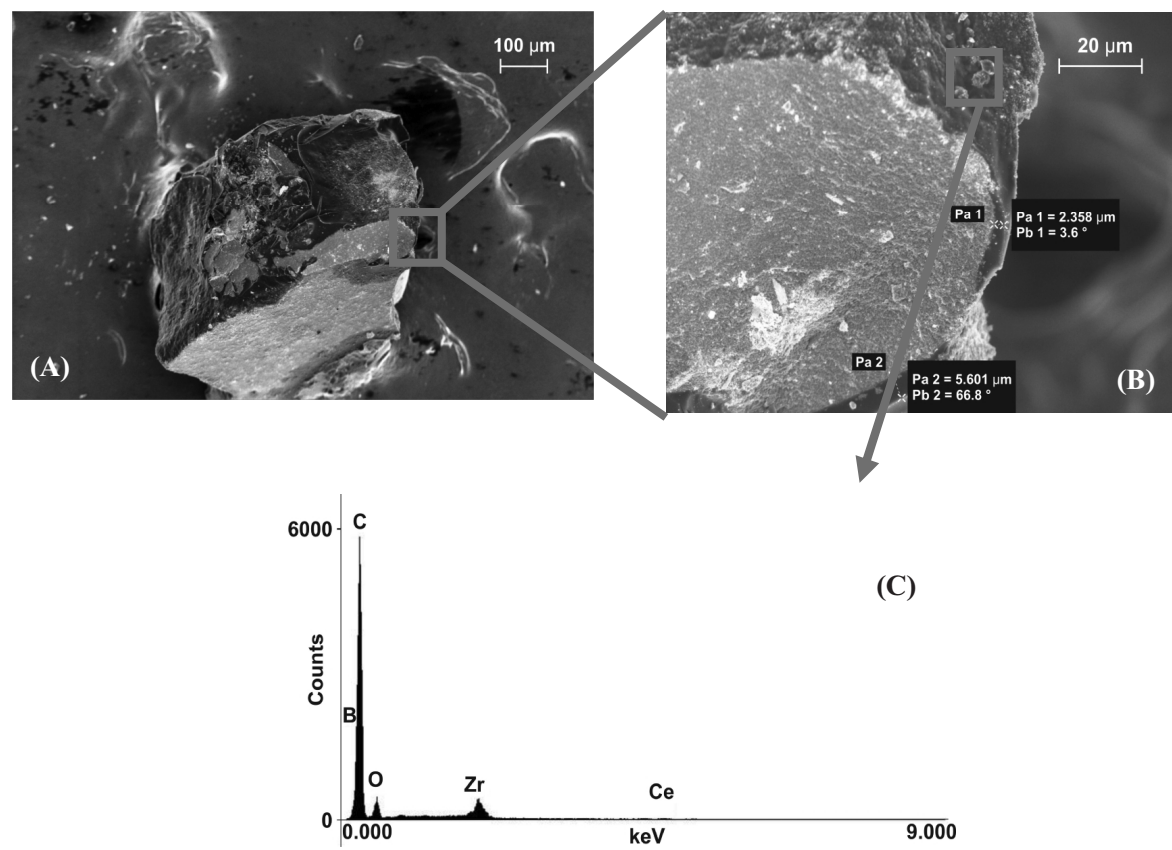

Figure 5.3. Top-view SEM images of internal char deposited on Ce-Zr-O, (A) Low magnification and (B) high magnification. (C) EDX analysis of a selected area.

Presence of internal char in $\mathrm{Ce}-\mathrm{Zr}-\mathrm{O}$ resulted in an increase in specific surface area $\left(86 \mathrm{~m}^{2} / \mathrm{g}\right)$ as compared to that determined in the absence of char $\left(18 \mathrm{~m}^{2} / \mathrm{g}\right)$. Nitrogen adsorption and pore volume distribution for internal char deposited on $\mathrm{Ce}-\mathrm{Zr}-\mathrm{O}$ are shown in Figure 5.4. The physisorption isotherm, Type $I V$, is characteristic for materials possessing mesoporosity. The corresponding hysteresis loop was associated with narrow slit-like pores, Type H4. Decrease in macropore volume (compare top insets Figure 5.1 and 5.4) when Ce-Zr-O was impregnated with internal char indicates that the char was located in the catalyst pores, influencing the textural properties of $\mathrm{Ce}-\mathrm{Zr}-\mathrm{O}$, in line with the SEM results. An oxidation treatment of this sample resulted in a macropore volume comparable to that of the fresh $\mathrm{Ce}-\mathrm{Zr}-\mathrm{O}$, confirming the location of char in the $\mathrm{Ce}-\mathrm{Zr}-\mathrm{O}$ pores (bottom inset Figure 5.4). 


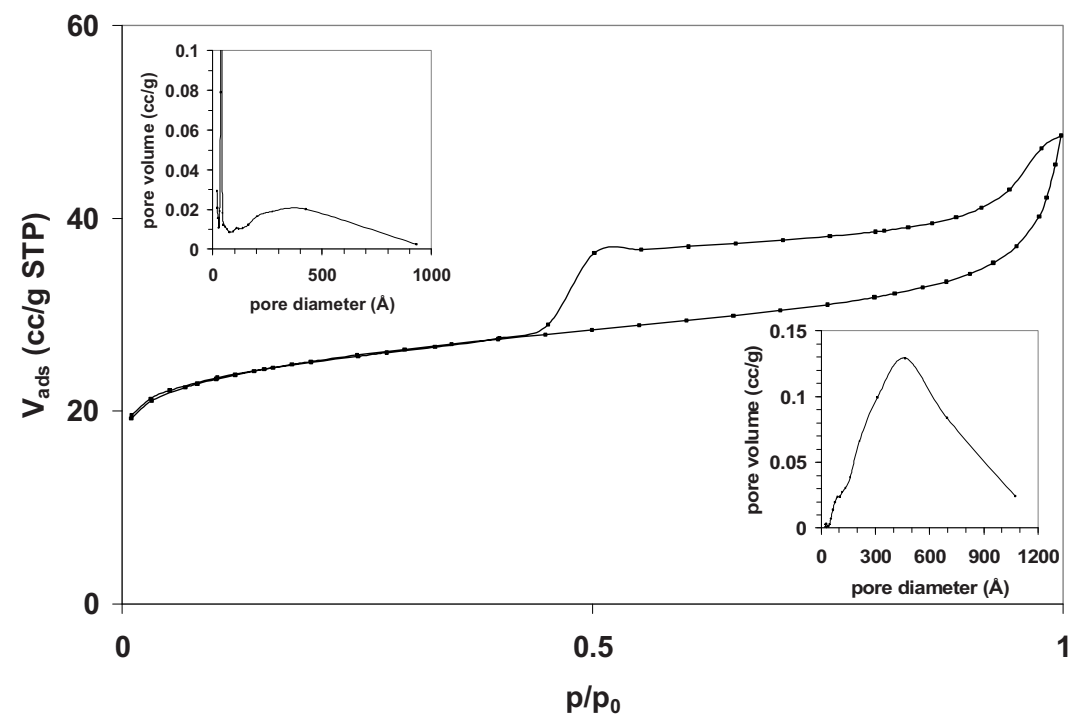

Figure 5.4. Nitrogen adsorption isotherm of internal char deposited on $\mathrm{Ce}-\mathrm{Zr}-\mathrm{O}$ and pore volume distribution of this sample before (top inset) and after (bottom inset) an oxidation treatment.

Figure 5.5 presents the XPS spectra of external char, Ce-Zr-O and internal char deposited on $\mathrm{Ce}-\mathrm{Zr}-\mathrm{O}$ in the regions of the binding energy of the $\mathrm{C} 1 \mathrm{~s}$ and $\mathrm{O} 1 \mathrm{~s}$. Figures 5.5A and 5.5B correspond to $\mathrm{C} 1 \mathrm{~s}$ spectra of internal char deposited on $\mathrm{Ce}-\mathrm{Zr}-\mathrm{O}$ and external char in the absence of Ce-Zr-O, respectively. Both spectra present a main peak at $285 \mathrm{eV}$, attributed to C-C and C-H bonds [20-22] in hydrocarbons, and a long tail at higher binding energies which is composed of 4 overlapping individual peaks associated to O-C type bond ( $\mathrm{C}-\mathrm{O}, \mathrm{C}=\mathrm{O}, \mathrm{O}-\mathrm{C}=\mathrm{O}$ and $\mathrm{CO}_{3}$ ) [20-22]. Comparison between the $\mathrm{C} 1 \mathrm{~s}$ spectra of both samples (Figure 5.5C) shows that O-C type bond $(>286 \mathrm{eV})$ is more dominant in internal char (formed in the presence of the Ce-Zr-O catalyst). 
(A)

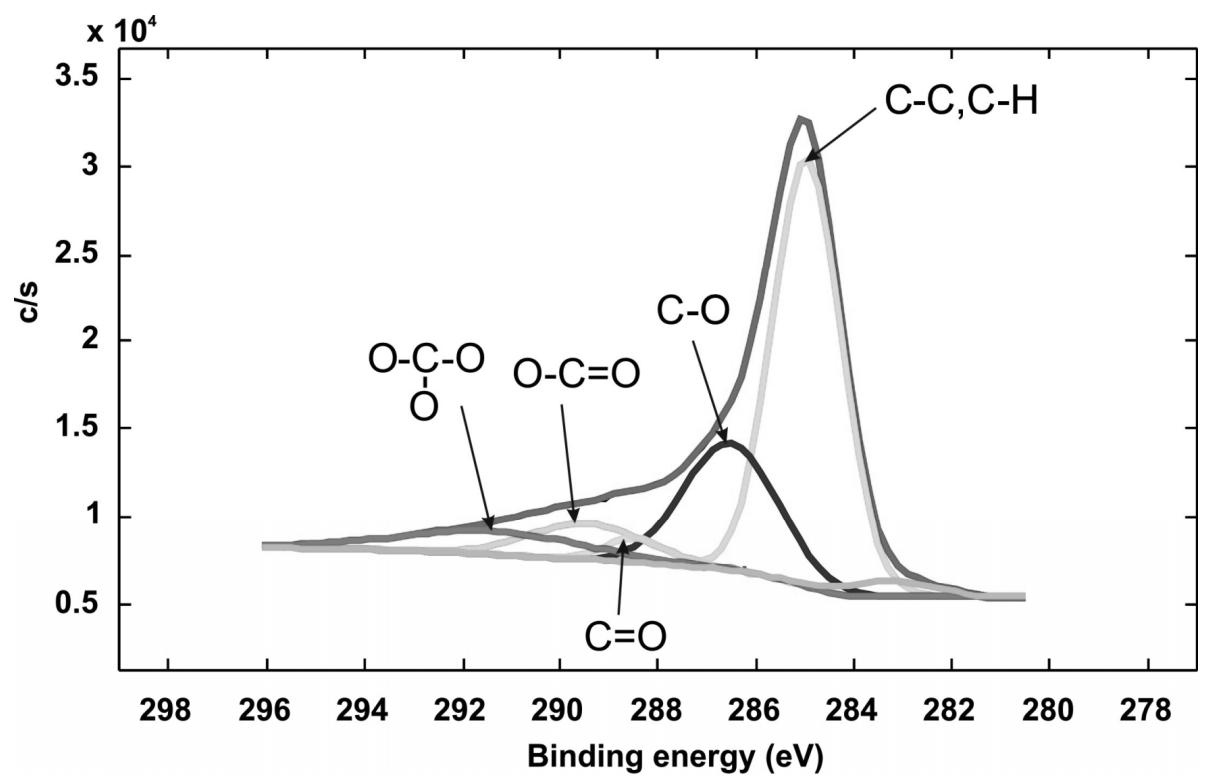

(B)

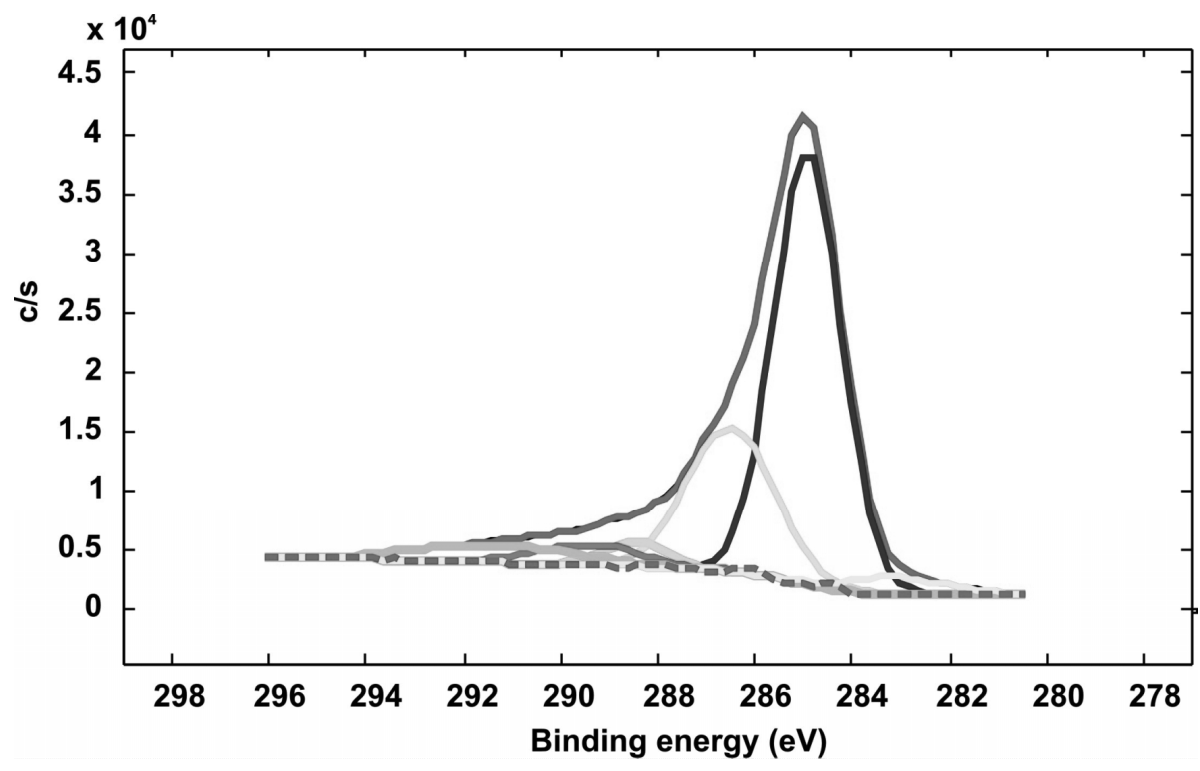


Chapter 5

(C)

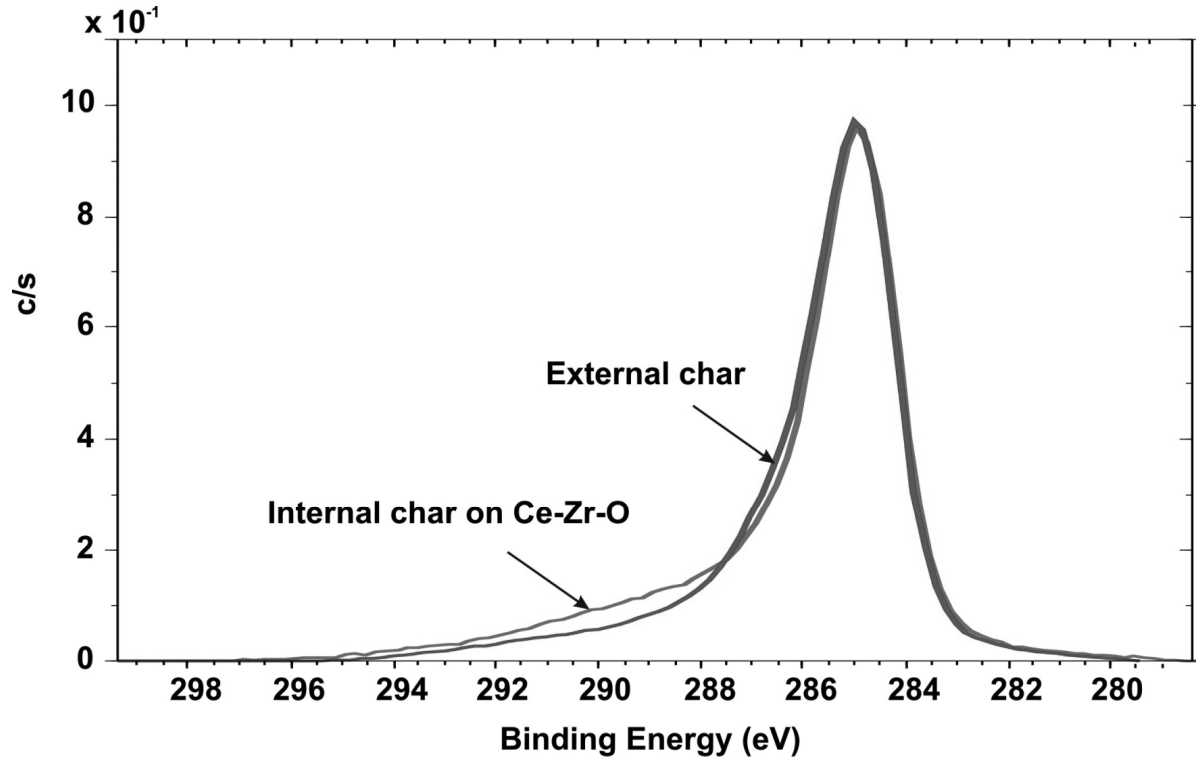

(D)

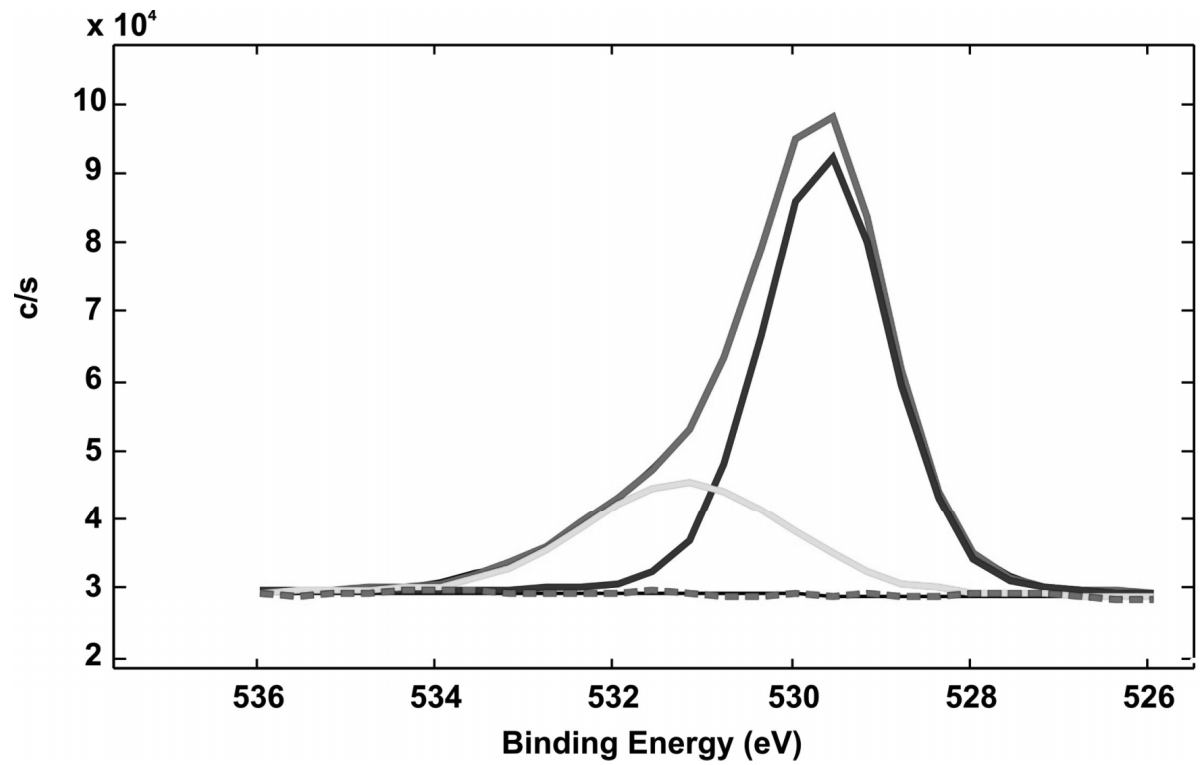


(E)

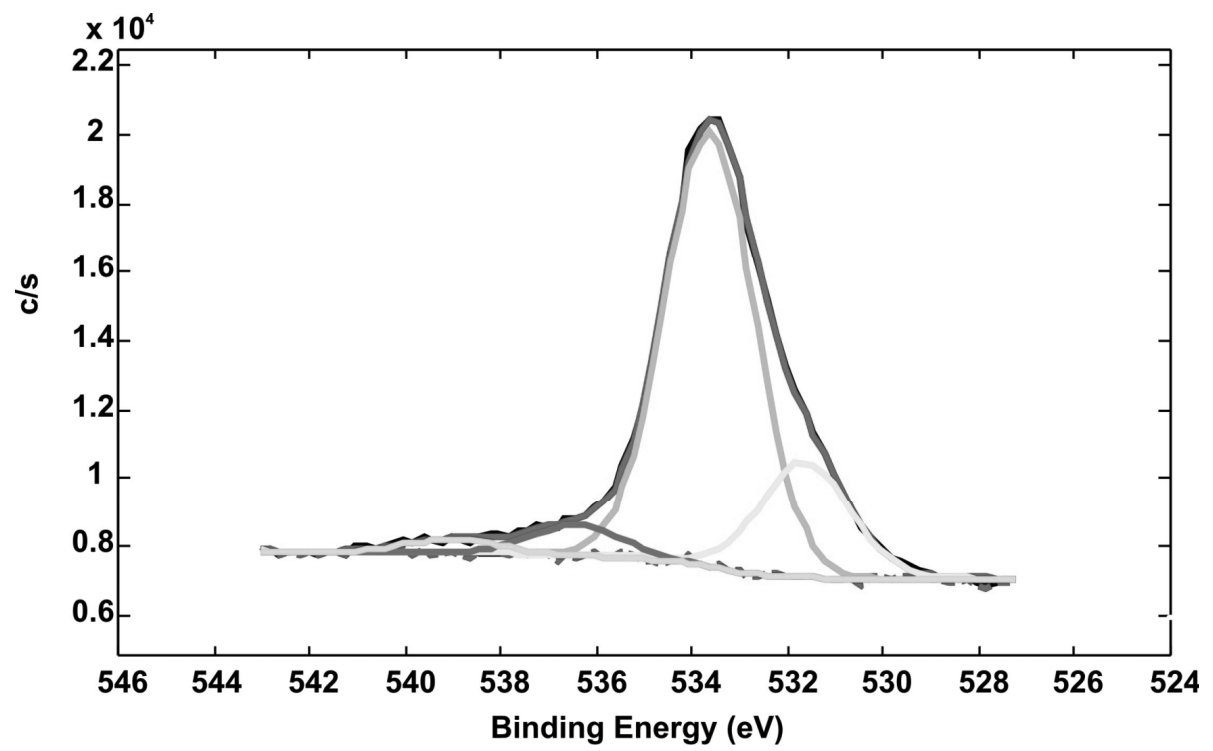

(F)

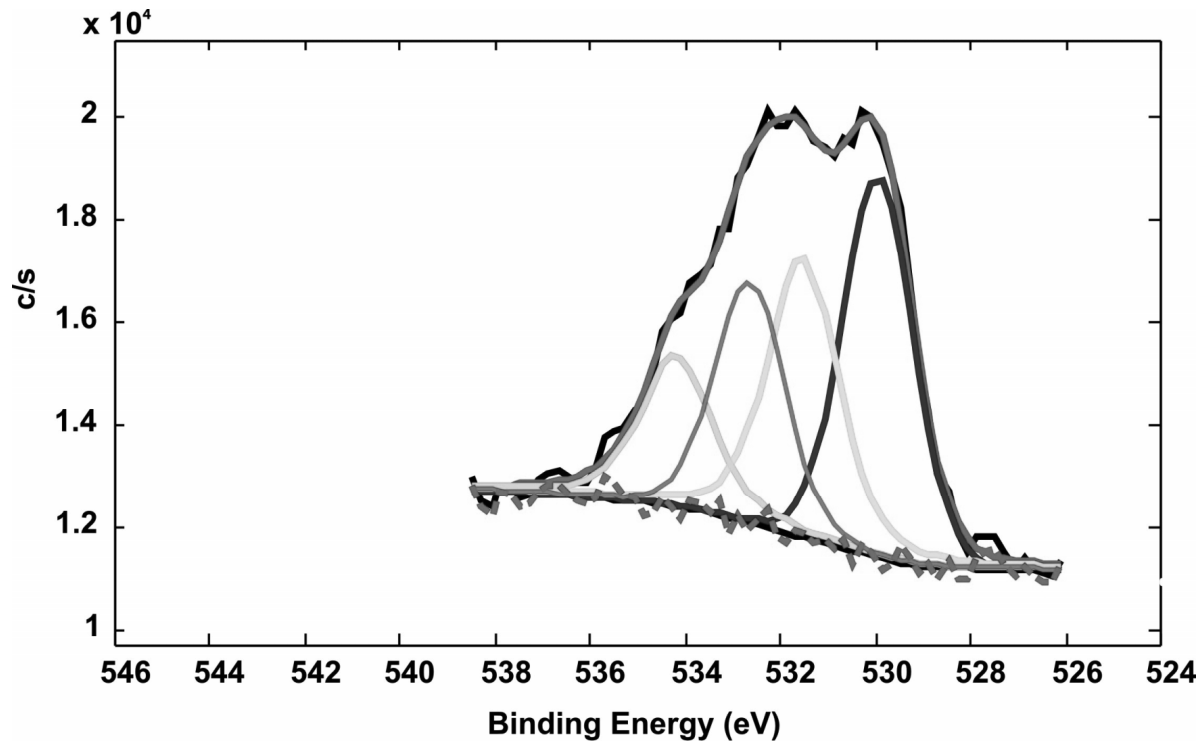


(G)

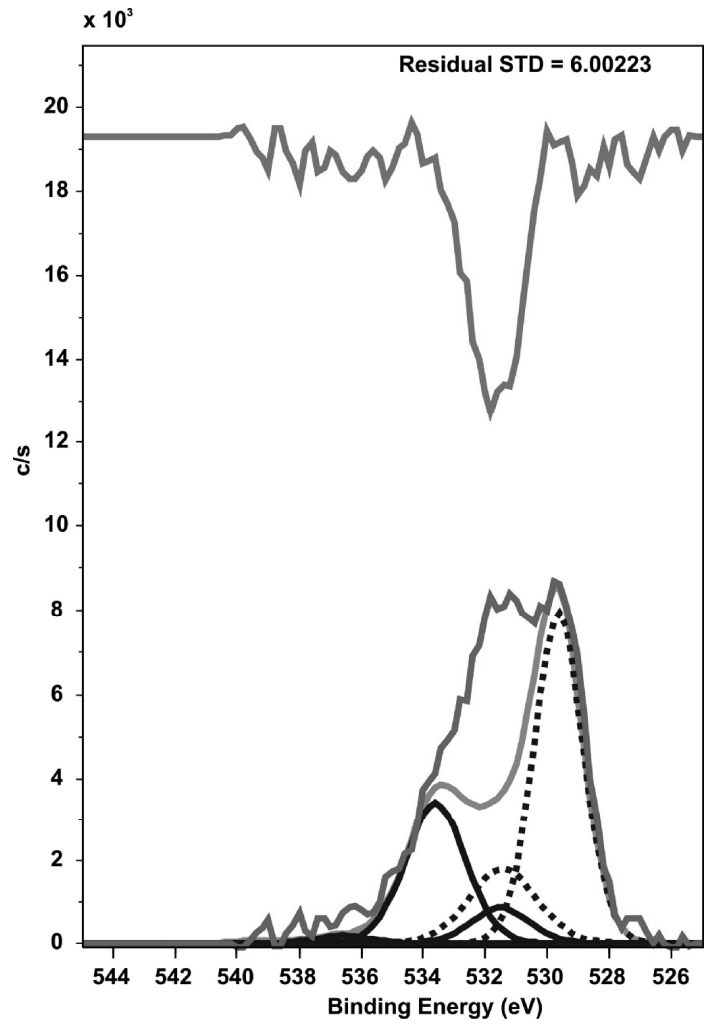

Figure 5.5. XPS spectra of (A) C1s internal char deposited on Ce-Zr-O, (B) C1s external char, (C) comparison C1s external char/internal char deposited on Ce-Zr-O, (D) O1s Ce-Zr-O, (E) O1s external char, (F) O1s internal char deposited on Ce-Zr-O (G) comparison O1s Ce-Zr-O (dash lines)/external char (dark solid lines)/internal char deposited on Ce-Zr-O (light solid line).

Spectra in the region of the binding energy of the O1s electrons are depicted in Figures 5.5D-G. The spectrum corresponding to Ce-Zr-O (Figure 5.5D) presents a peak which can be described as contribution from two different types of oxygen. One type of oxygen is assigned to a main peak centered at $531.2 \mathrm{eV}$ and the second one is associated to a minor peak centered at $532.2 \mathrm{eV}$. The $\mathrm{O} 1 \mathrm{~s}$ fitting of the spectrum corresponding to external char is shown in Figure 5.5E. In this case, the optimal fitting of the curve is constituted of 4 peaks, at positions $531.6 \mathrm{eV}, 533.6 \mathrm{eV}, 536.4 \mathrm{eV}$ and $539.0 \mathrm{eV}$. The first two peaks are assigned to $\mathrm{C}=\mathrm{O}$ and $\mathrm{C}-\mathrm{O}$ bonds, respectively, and the other two at higher 
binding energies are satellite peaks [20-22]. Figure 5.5F shows the O1s fitting spectrum of internal char deposited on Ce-Zr-O. A broad peak in the range $528-538 \mathrm{eV}$ was observed. The best fitting for this peak was obtained with the addition of four individual bands at the following binding energies: $529.9 \mathrm{eV}, 531.5 \mathrm{eV}, 532.6 \mathrm{eV}$ and $534.17 \mathrm{eV}$. Figure $5.5 \mathrm{G}$ shows the overlapping of the O1s spectrum of internal char deposited on $\mathrm{Ce}-\mathrm{Zr}-\mathrm{O}$ (light solid line) with the individual curves and the resulting fitting of the O1s spectra corresponding to Ce-Zr-O (dash lines) and external char (dark solid lines). To do so, the parameters associated with the main band for both $\mathrm{Ce}-\mathrm{Zr}-\mathrm{O}$ and external char, namely peak position, area and full width half maximum (FWHM), were constrained when comparing them with the O1s spectrum of internal char deposited on the catalyst. The parameters associated with the rest of the individual bands depended on those associated with the main band (see Tables 5.1 and 5.2). It is clear from Figure 5.5G that the fitting resulting from the sum up of the 6 individual bands ( 2 from $\mathrm{Ce}-\mathrm{Zr}-\mathrm{O}$ and 4 from external char) was not equivalent to the $\mathrm{O} 1 \mathrm{~s}$ spectrum associated with internal char deposited on Ce-Zr-O. There was remaining intensity which could not be explained by any of the individual components. This remaining peak, so-called residual, shown on the top of the figure, was in the binding energy range $530.2-533.5 \mathrm{eV}$. This binding energy range is typical of $\mathrm{O}-\mathrm{C}$ bonds $\left(\mathrm{CO}_{3}[20]\right)$, in good agreement with the findings obtained for C1s (Figure 5.5A).

Table 5.1. Quantification parameters of the $\mathrm{O} 1 \mathrm{~s}$ spectrum of char

\begin{tabular}{c|ccccc}
\hline Band & Peak position & Area & FWHM & Delta peak position & Area \\
\hline 1 & 533.7 & 30516 & 2.23 & 0 & $\mathrm{~A}$ \\
2 & 531.6 & 7714 & 2.23 & -2.1 & $\mathrm{~A} * 0.252$ \\
3 & 536.7 & 1731 & 2.23 & +3.0 & $\mathrm{~A} * 0.057$ \\
4 & 539.2 & 744 & 2.23 & +5.5 & $\mathrm{~A} * 0.024$
\end{tabular}

Table 5.2. Quantification parameters of the O1s spectrum of CeYSZ

\begin{tabular}{c|cccccc}
\hline Band & Peak position & Area & FWHM & Delta peak position & Area & Delta FWHM \\
\hline 1 & 529.6 & 81655 & 1.80 & 0 & A & 0 \\
2 & 531.4 & 25969 & 2.54 & +1.8 & $\mathrm{~A}^{*} 0.318$ & +0.74
\end{tabular}




\subsubsection{Reactivity measurements}

\subsubsection{1 $\mathrm{CO}_{2}$ gasification}

Figure 5.6 shows a typical result for $\mathrm{CO}_{2}$ (dry) gasification of char expressed as char conversion $v s$. reaction time at $700{ }^{\circ} \mathrm{C}$. Reactions rate $\left(r_{w t}\right)$ can be calculated with the derivative. The resulting rates for internal char (deposited on $\mathrm{Ce}-\mathrm{Zr}-\mathrm{O}$ ) in the temperature range between 600 and $800{ }^{\circ} \mathrm{C}$ are shown in Figure 5.7 as a function of the conversion. As can be clearly seen, char reactivity increased sharply with temperature. The initial rate of gasification at $800{ }^{\circ} \mathrm{C}$ was approximately one order of magnitude higher than that $600{ }^{\circ} \mathrm{C}$. The influence of temperature in the reactivity profile is also observed in Figure 5.7. At low temperatures $\left(600^{\circ} \mathrm{C}\right)$, char was gasified at a relatively constant rate throughout the whole experiment whereas the rate of gasification at higher temperatures $\left(700{ }^{\circ} \mathrm{C}\right.$ and $\left.800{ }^{\circ} \mathrm{C}\right)$ decreased significantly with conversion.

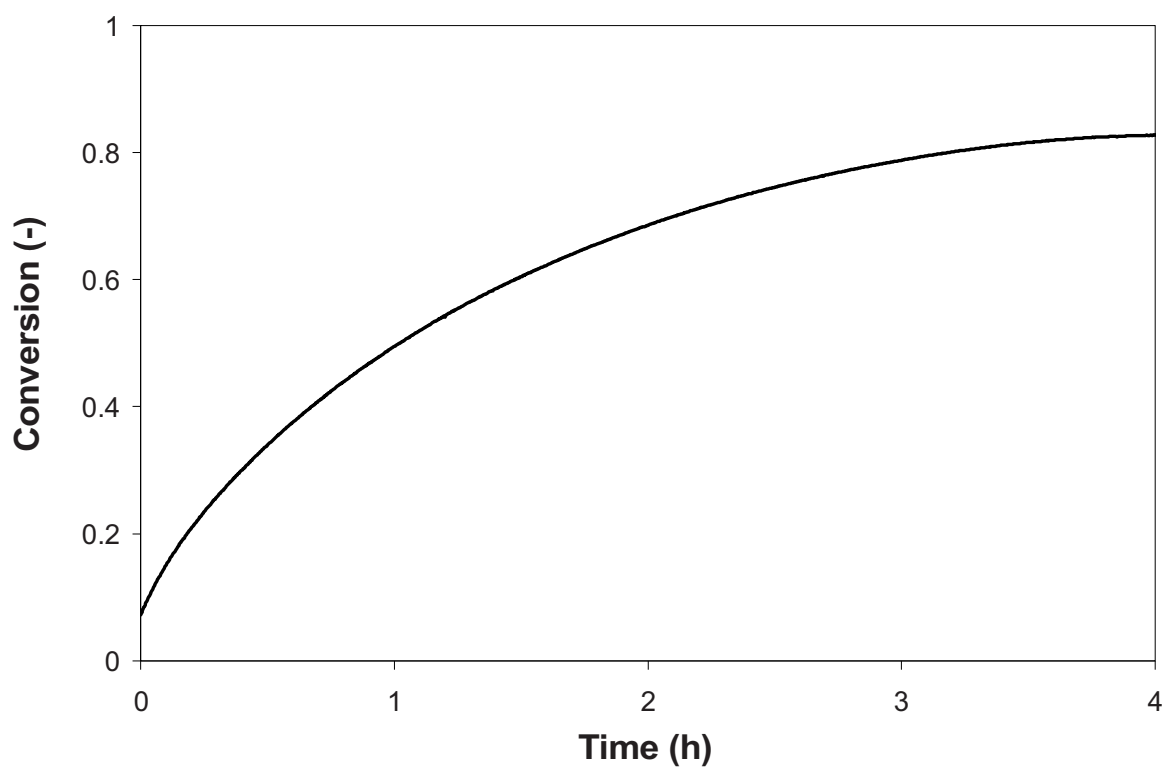

Figure 5.6. Char conversion as a function of reaction time for $\mathrm{CO}_{2}$ gasification of internal char deposited on Ce-Zr-O at $700{ }^{\circ} \mathrm{C} . \mathrm{CO}_{2}$ flow: $20 \mathrm{ml} / \mathrm{min}$; Ar flow: $40 \mathrm{ml} / \mathrm{min}$. 
Comparison of char reactivity at 0.3 conversion in the presence (internal char) and absence (external char) of Ce-Zr-O is illustrated in Figure 5.8. As expected, the presence of $\mathrm{Ce}-\mathrm{Zr}-\mathrm{O}$ had a significant influence on the rate of gasification, especially at the higher temperatures, e.g. the presence of $\mathrm{Ce}-\mathrm{Zr}-\mathrm{O}$ allowed char to gasify one order of magnitude faster than char gasified noncatalytically.

Figure 5.8 also shows the reactivity at 0.3 conversion of internal char deposited on $\mathrm{SiO}_{2}$ at $700{ }^{\circ} \mathrm{C}$. The reactivity in this case was comparable to that observed noncatalytically, indicating the inertness of $\mathrm{SiO}_{2}$.

Table 5.3 compares the activation energies calculated according the Arrhenius equation for the catalytic (internal char deposited on $\mathrm{Ce}-\mathrm{Zr}-\mathrm{O}$ ) and the noncatalytic (external char) $\mathrm{CO}_{2}$ gasification. As expected, the presence of $\mathrm{Ce}-\mathrm{Zr}-\mathrm{O}$ lowered the activation energy.

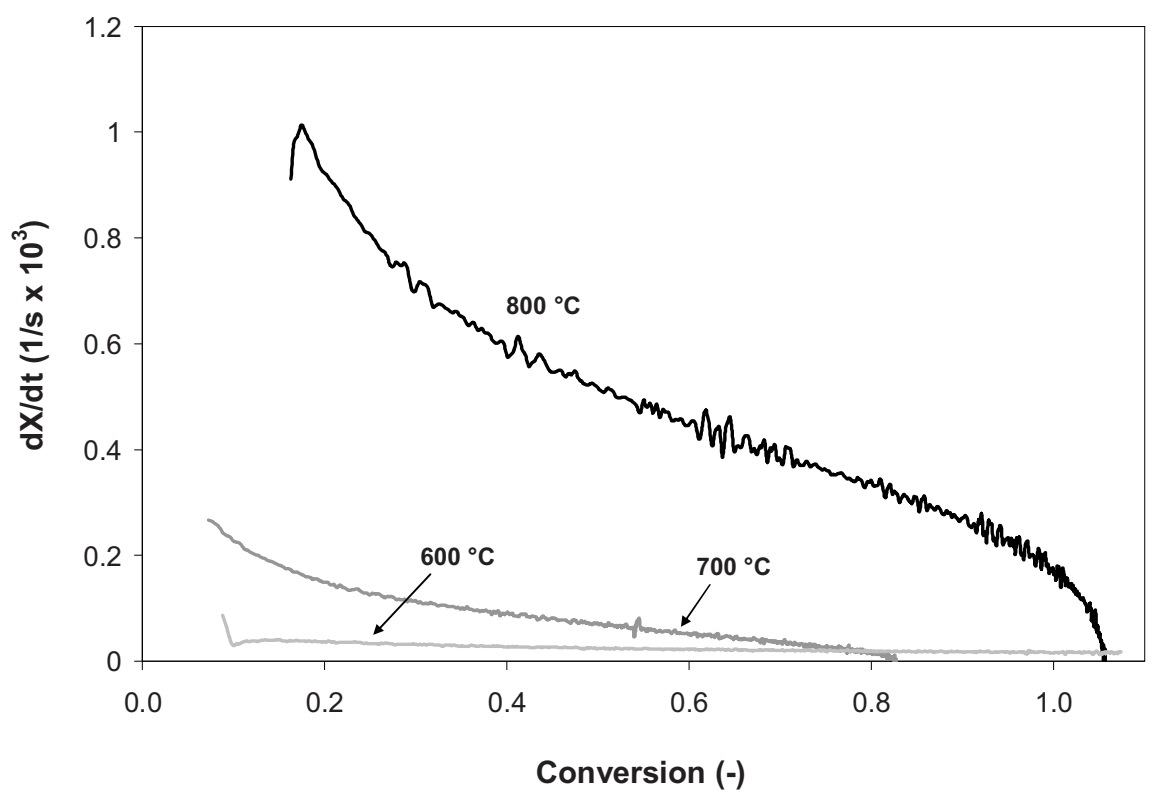

Figure 5.7. Reactivity of internal char in the presence of catalyst as a function of the degree of conversion during $\mathrm{CO}_{2}$ gasification. $\mathrm{CO}_{2}$ flow: $20 \mathrm{ml} / \mathrm{min}$; Ar flow: $40 \mathrm{ml} / \mathrm{min}$. 


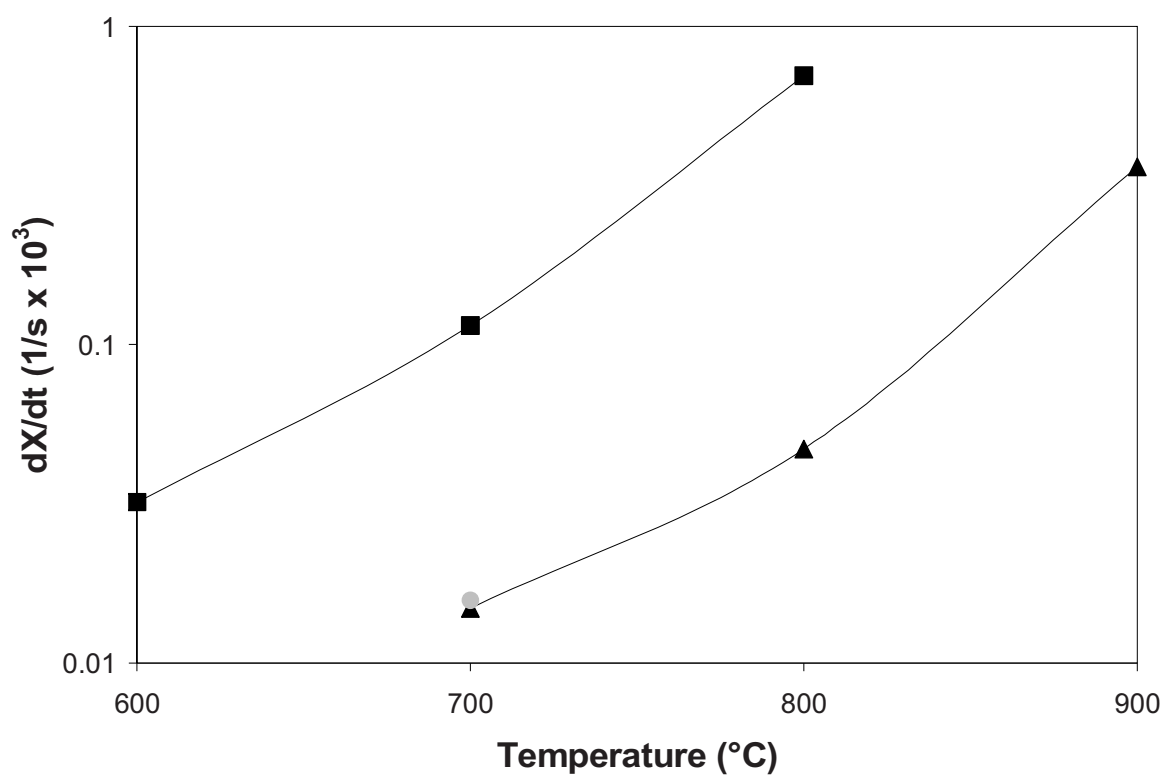

Figure 5.8. Char reactivity during $\mathrm{CO}_{2}$ gasification at $\mathrm{X}=0.3$ as a function of temperature in the absence (external char) and presence (internal char) of catalyst. ( $\mathbf{\Delta})$ external char, ( $\mathbf{(})$ internal char deposited on Ce-Zr-O and (o) internal char deposited on $\mathrm{SiO}_{2}$.

$\mathrm{CO}_{2}$ flow: $20 \mathrm{ml} / \mathrm{min}$, Ar flow: $40 \mathrm{ml} / \mathrm{min}$.

Table 3. Activation energies calculated by the Arrhenius equation for the catalytic and noncatalytic steam and $\mathrm{CO}_{2}$ gasification of char

\begin{tabular}{c|cc}
\hline & $\mathrm{Ea}(\mathrm{kJ} / \mathrm{mol})$ \\
& $\mathrm{H}_{2} \mathrm{O}$ & $\mathrm{CO}_{2}$ \\
\hline Catalytic & 157 & 119 \\
Noncatalytic & 274 & 160
\end{tabular}

\subsubsection{Steam gasification}

Reactivity profiles for the steam gasification of internal char deposited on $\mathrm{Ce}-\mathrm{Zr}-\mathrm{O}$ as a function of the degree of conversion and temperature are shown in Figure 5.9. Similar to dry $\left(\mathrm{CO}_{2}\right)$ gasification, both reactivity profile and rate of gasification were found to strongly depend on temperature. Char gasification at $581{ }^{\circ} \mathrm{C}$ was very slow and constant. 
The increase in temperature up to $623{ }^{\circ} \mathrm{C}$ increased the rate of gasification by a factor of 4 and resulted in a comparable reactivity profile. Char reactivity was further increased when carrying out experiments at $736{ }^{\circ} \mathrm{C}$. Reactivity at this reaction temperature was approximately 40 times faster than that obtained at $581{ }^{\circ} \mathrm{C}$. In contrast to the observations at lower temperatures, reactivity at $736{ }^{\circ} \mathrm{C}$ decreased as char was being consumed.

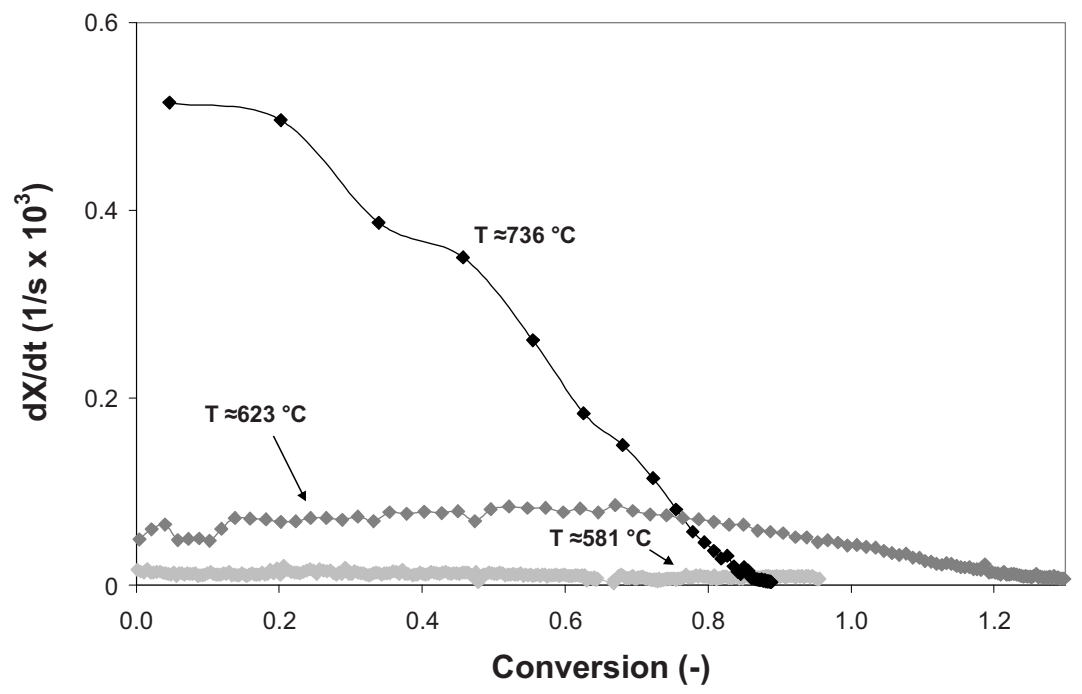

Figure 5.9. Reactivity of internal char in the presence of catalyst as a function of the degree of conversion during steam gasification. Steam flow: $0.15-0.5 \mathrm{~g} / \mathrm{min}, \mathrm{N}_{2}$ flow: $9 \mathrm{ml} / \mathrm{min}$. $\mathrm{T} \approx 581{ }^{\circ} \mathrm{C}$ $(\diamond), \Delta \mathrm{p} \approx 0.2$ bar; $\mathrm{T} \approx 623{ }^{\circ} \mathrm{C}, \Delta \mathrm{p} \approx 0.2 \operatorname{bar}(\diamond) ; \mathrm{T} \approx 736^{\circ} \mathrm{C}, \Delta \mathrm{p} \approx 0.3 \operatorname{bar}(\diamond)$.

Char reactivity for steam gasification in the presence (internal char) and absence (external char) of Ce-Zr-O is compared at 0.3 conversion in Figure 5.10. Similar to our findings for $\mathrm{CO}_{2}$ gasification, char reactivity during steam gasification was enhanced by the presence of $\mathrm{Ce}-\mathrm{Zr}-\mathrm{O}$, however to a lower extent. Comparison between reaction times at approximately $735{ }^{\circ} \mathrm{C}$ indicates that char gasification occurred $\sim 3.5$ times faster when the reaction was carried out catalytically.

Regarding the gas product distribution, $\mathrm{H}_{2}, \mathrm{CO}$, and $\mathrm{CO}_{2}$ were the only products formed during gasification of the internal char deposited on Ce-Zr-O. In the noncatalytic case (external char), besides the above mentioned products, small amounts of $\mathrm{CH}_{4}$ were 
also observed in the beginning of the reaction. The $\mathrm{CO} / \mathrm{CO}_{2}$ ratio during catalytic internal char gasification was approximately 0.06 whereas $\mathrm{CO}$ and $\mathrm{CO}_{2}$ concentrations were comparable in the noncatalytic case, indicating that in the presence of $\mathrm{Ce}-\mathrm{Zr}-\mathrm{O}$ the watergas shift equilibrium was completely shifted towards $\mathrm{CO}_{2}$ and $\mathrm{H}_{2}$ production.

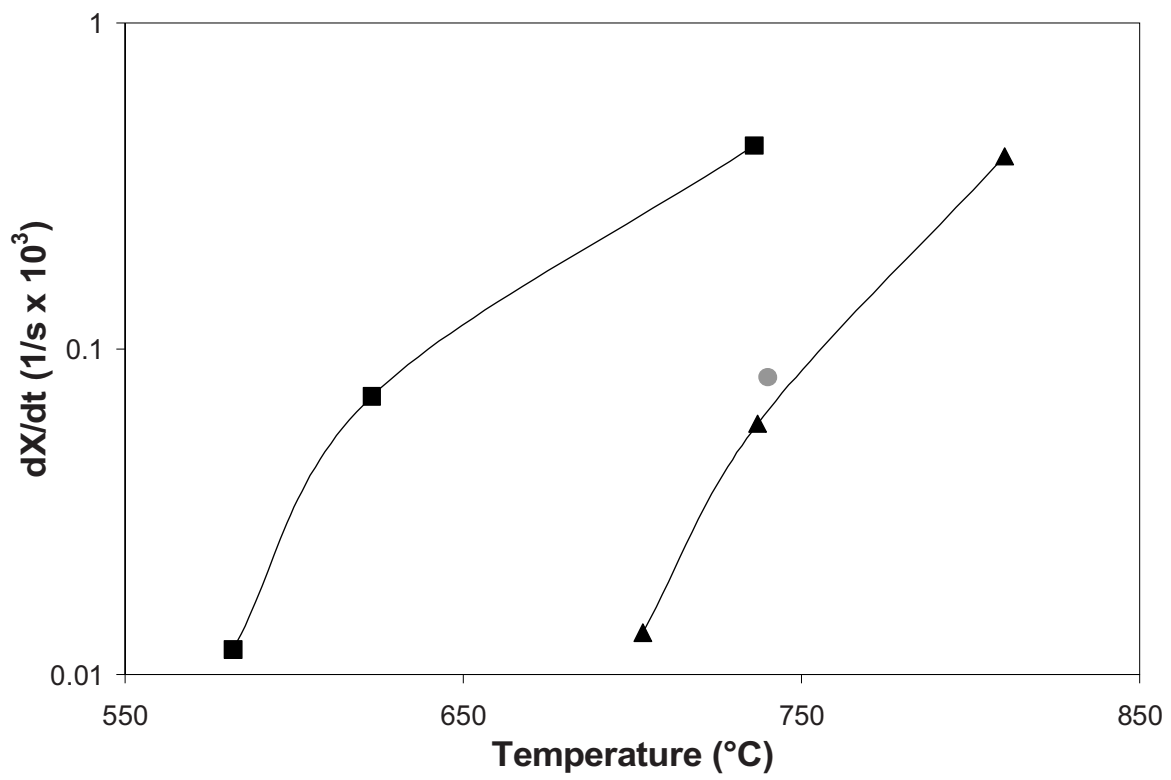

Figure 5.10. Char reactivity during steam gasification at $X=0.3$ as a function of temperature in the absence (external char) and presence (internal and physical mixing char) of catalyst. ( $\boldsymbol{\Delta})$ external char, (๘) internal char deposited on Ce-Zr-O and (๑) physical mix char with Ce-Zr-O. Steam flow: 0.15-0.5 g/min; $\mathrm{N}_{2}$ flow: $9 \mathrm{ml} / \mathrm{min}$.

Figure 5.10 also includes reactivity of char physically mixed with $\mathrm{Ce}-\mathrm{Zr}-\mathrm{O}$ (solidsolid contact) at $740{ }^{\circ} \mathrm{C}$. It can be seen from the Figure that the reactivity of this char was remarkably slower ( $\sim 3$ times) than that observed for internal char deposited on $\mathrm{Ce}-\mathrm{Zr}-\mathrm{O}$ and comparable to that associated with external char (gasified noncatalytically) under similar reaction conditions. These results clearly indicate that physical mixing of char with catalyst particles resulted in poor contact and thus, char gasification is only enhanced marginally by the presence of the Ce-Zr-O catalyst. 
Table 5.3 shows, similarly to the observations on $\mathrm{CO}_{2}$ gasification, that the presence of Ce-Zr-O (internal char) decreased the activation energy significantly.

\subsubsection{Combustion}

Figure 5.11 shows the reactivity profiles for char combustion in the presence (internal char) and absence (external char) of $\mathrm{Ce}-\mathrm{Zr}-\mathrm{O}$ as a function of temperature. Char combusted noncatalytically resulted in a main peak centered around $460{ }^{\circ} \mathrm{C}$ and a smaller, second peak with maximum at $530{ }^{\circ} \mathrm{C}$. The presence of $\mathrm{Ce}-\mathrm{Zr}-\mathrm{O}$ enhanced char combustion drastically, as evidenced by the presence of a single peak centered at $330{ }^{\circ} \mathrm{C}$.

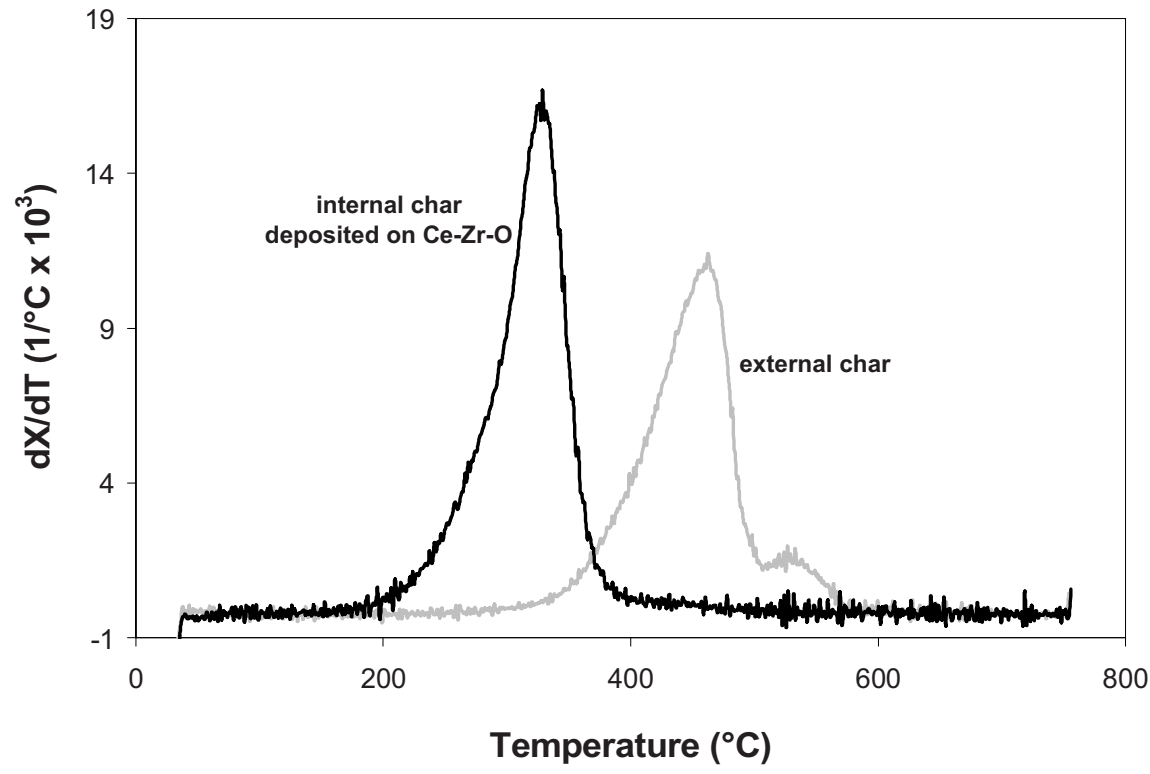

Figure 5.11. Char reactivity during combustion as a function of temperature in the absence (external char) and presence (internal char) of catalyst. Air flow: $20 \mathrm{ml} / \mathrm{min}$,

Ar flow: $40 \mathrm{ml} / \mathrm{min}$, heating rate: $5{ }^{\circ} \mathrm{C} / \mathrm{min}$. 


\subsection{Discussion}

This work in this Chapter reports on catalytic steam gasification of pyrolysis oil derived char and adds on noncatalytic findings (Chapter 4). Additionally, this work addresses catalytic $\mathrm{CO}_{2}$ gasification and char combustion as alternative approaches to convert char formed during pyrolysis oil evaporation. The kinetic results show the effectiveness of the ceria-zirconia catalyst to convert char to syngas via catalytic steam and $\mathrm{CO}_{2}$ gasification at relatively low temperatures $\left(<700{ }^{\circ} \mathrm{C}\right)$, as evidenced by the substantial enhancement in char reactivity and the decrease in activation energies, as compared to the noncatalytic scenario (see Figures 5.8 and 5.10).

In addition, this catalyst showed excellent combustion activity. In the presence of $\mathrm{Ce}-\mathrm{Zr}-\mathrm{O}$, internal char was fully combusted at temperatures below $400{ }^{\circ} \mathrm{C}$ whereas noncatalytic combustion of (external) char required temperatures up to $\sim 570{ }^{\circ} \mathrm{C}$. This enhanced reactivity by using ceria-based catalyst is in good agreement with results of McKee [23] on combustion of graphite, reporting that addition of $\mathrm{Ce}$ to the graphite allowed initial combustion of graphite at $450{ }^{\circ} \mathrm{C}$, instead of $700{ }^{\circ} \mathrm{C}$ in absence of catalyst.

It is here appropriate to recall that external char, produced in the absence of catalyst, was formed at $525{ }^{\circ} \mathrm{C}$. On the other hand, internal char, formed in-situ on the catalyst, was produced by heating the catalyst impregnated with oil up to $750{ }^{\circ} \mathrm{C}$. Thus, the char produced catalytically was formed at higher temperatures. We have reported in Chapter 4 that reactivity of char strongly depends on the temperature at which it is formed. The higher the temperature the more devolatilization (gas release) char undergoes, resulting in a lower reactivity of char. Accordingly, the char produced in the presence of catalyst should be less reactive than char produced noncatalytically. Therefore, the already catalytic effect of the ceria-zirconia catalyst on gasification and combustion rates is more significant and as a consequence, the temperature required for char conversion could be lowered even further, especially since pyrolysis oil evaporation can be carried out at lower temperatures (e.g. $\left.500{ }^{\circ} \mathrm{C}\right)$.

It is well known that $\mathrm{CeO}_{2}$ has excellent oxygen exchange capacity involving red-ox changes between $\mathrm{Ce}^{4+}$ and $\mathrm{Ce}^{3+}[24]$ and that it has ability to activate $\mathrm{H}_{2} \mathrm{O}$ and $\mathrm{CO}_{2}$. Sharma et al. [14] proved that re-oxidation of $\mathrm{CeO}_{2-\mathrm{x}}$ by $\mathrm{CO}_{2}$ occurs at temperatures as low as $350{ }^{\circ} \mathrm{C}$. Further, water activation $\left(\mathrm{CeO}_{2-x}\right.$ re-oxidation $)$ over ceria was reported to 
proceed rapidly at $550{ }^{\circ} \mathrm{C}$ [25]. Therefore both reactants, $\mathrm{CO}_{2}$ and $\mathrm{H}_{2} \mathrm{O}$, are activated on $\mathrm{Ce}-\mathrm{Zr}-\mathrm{O}$ at the reaction temperatures used in this study. Interestingly, our kinetic results reveal that noncatalytic steam gasification of char was significantly faster (up to one order of magnitude at $800{ }^{\circ} \mathrm{C}$ ) than $\mathrm{CO}_{2}$ gasification (compare Figures 5.8 and 5.10). In contrast, under comparable reaction conditions and in the presence of $\mathrm{Ce}-\mathrm{Zr}-\mathrm{O}$, the rate for steam gasification was only slightly higher than that observed for $\mathrm{CO}_{2}$ gasification. These facts indicate that the $\mathrm{Ce}-\mathrm{Zr}-\mathrm{O}$ red-ox catalyst is able to speed up gasification with $\mathrm{CO}_{2}$ even more effectively than with water.

Differences in the $\mathrm{CO} / \mathrm{CO}_{2}$ ratio and $\mathrm{H}_{2}$ amounts between catalytic and noncatalytic gasification of char confirms that $\mathrm{Ce}-\mathrm{Zr}-\mathrm{O}$ can readily activate both $\mathrm{H}_{2} \mathrm{O}$ and $\mathrm{CO}_{2}$. In the case of catalytic steam gasification (internal char deposited on $\mathrm{Ce}-\mathrm{Zr}-\mathrm{O}$ ), the $\mathrm{CO} / \mathrm{CO}_{2}$ ratio was much lower than that observed noncatalytically (external char) $(\sim 0.06 v s .1)$, indicating that in the presence of $\mathrm{Ce}-\mathrm{Zr}-\mathrm{O}$ the water-gas shift equilibrium was shifted towards $\mathrm{CO}_{2}$ and $\mathrm{H}_{2}$ production, in agreement with literature [26-28]. It is important to highlight that, in contrast to alkali-based and earth-alikali based ( $\mathrm{K}, \mathrm{Na}, \mathrm{Mg}, \mathrm{Ca}$, ect.) or Ni-based catalysts [29-31], used in catalytic coal gasification, ceria-zirconia catalysts do not catalyze the methanation reaction when mixed with carbon $[12,30,32,33]$ and thus syngas yields remain high.

Characterization results suggest that $\mathrm{Ce}-\mathrm{Zr}-\mathrm{O}$ also plays a crucial role in the nature of char formed during pyrolysis oil evaporation (internal char) and this could also explain the differences in char reactivity between catalytic and noncatalytic conditions. It was concluded from XPS spectra that char produced during pyrolysis oil evaporation in the presence of $\mathrm{Ce}-\mathrm{Zr}-\mathrm{O}$ was more oxygenated than that formed noncatalytically. Domazetis et al. [30] observed similar oxygenate species for the catalytic gasification of low-quality coals over Fe-based catalysts. The authors speculated that Fe-oxygenate complexes formed during pyrolysis participate in metal assisted pyrolysis and gasification. As mentioned earlier, it is well established that ceria possesses excellent red-ox properties $[34,35]$, generating oxygen vacancies and thus allowing release and storage of oxygen ('oxygen storage capacity' OSC) [35,36]. Therefore, we may speculate that occurrence of oxygen release from ceria during pyrolysis oil evaporation resulted in oxygen vacancies and formation of new carbon-oxygen bonds in char (e.g. carbonyl and carbonate groups). 
$\mathrm{H}_{2} \mathrm{O}$ and $\mathrm{CO}_{2}$ (potential oxidants) released in gas phase during evaporation would be able to fill in the generated oxygen vacancies in ceria.

Evolution of these new C-O type of bonds suggests that the contact between (internal) char and $\mathrm{Ce}-\mathrm{Zr}-\mathrm{O}$ was excellent. This hypothesis was confirmed by SEM images (Figure 5.2), which showed that char was located inside the pores of Ce-Zr-O and thus in intimate contact with the catalyst. Change in porosity between fresh $\mathrm{Ce}-\mathrm{Zr}-\mathrm{O}$ and $\mathrm{Ce}-\mathrm{Zr}-\mathrm{O}$ mixed with internal char (compare Figures 5.1 and 5.4) also suggested that char was mostly deposited in the macropores of $\mathrm{Ce}-\mathrm{Zr}-\mathrm{O}$, in agreement with our previous findings. Further porosity measurements of a sample containing internal char deposited on $\mathrm{Ce}-\mathrm{Zr}-\mathrm{O}$ which had been previously submitted to an oxidation treatment $\left(\mathrm{O}_{2} / \mathrm{He}\right)$ (see Figure 5.4 bottom inset) corroborated the location of char by showing comparable porosity to that observed for the fresh Ce-Zr-O. A small amount of char, however, formed an external thin surface layer of few $\mu \mathrm{m}$ thick (see Figure 5.3B). This suggests that a small fraction of the oil did not penetrate into the catalyst pores prior to char formation, resulting in overimpregnation of the catalyst particles. As a consequence, this small amount of char was not in intimate contact with the catalyst, resulting in a slightly lower rate of gasification. Therefore, higher char reactivities could be obtained by optimizing (i) catalyst/pyrolysis ratios and (ii) contact between catalyst/char.

$\mathrm{Up}$ to this point, our findings show the significant role of the Ce-Zr-O catalyst in enhancing char reactivity during steam and $\mathrm{CO}_{2}$ gasification; however, discrimination between the role of the catalyst during pyrolysis oil evaporation and that during char gasification requires further research.

In the case of coal gasification, it has been stated in literature that surface area plays an important role in the rate of gasification. The higher the surface area the faster the gasification rate is $[37,38]$. In order to study the influence of catalyst surface area in char gasification, $\mathrm{CO}_{2}$ gasification of internal char was carried out over $\mathrm{SiO}_{2}$ with very high surface area $\left(351 \mathrm{~m}^{2} / \mathrm{g}\right)$ and with no ability to activate $\mathrm{CO}_{2}$. The low gasification rate obtained over this $\mathrm{SiO}_{2}$ (Figure 5.8), comparable to that observed noncatalytically and much lower than that over $\mathrm{Ce}-\mathrm{Zr}-\mathrm{O}$, confirmed the essential role of $\mathrm{Ce}-\mathrm{Zr}-\mathrm{O}$ in activating $\mathrm{CO}_{2}$ and $\mathrm{H}_{2} \mathrm{O}$ and thus enhancing char gasification and ruled out any positive contribution of surface area of noncatalytic materials in the rate of char gasification. Based on our observations and discussions we thus propose that ceria provides oxygen 
for char gasification, resulting in oxygen vacancies, and that activation of $\mathrm{CO}_{2}$ and $\mathrm{H}_{2} \mathrm{O}$ on Ce-Zr-O leads to regeneration of the oxygen vacancies. This is consistent with our studies of steam reforming of acetic acid [15] and water-gas shift [39], where the role of ceria is suggested and observed. Another important observation is that differences in char production which are expected to result in different char structures, yielded to comparable gasification rates, as observed for internal char deposited on $\mathrm{SiO}_{2}$ (char produced at low heating rate) and external char (char produced at high heating rate [3]).

The catalytic activity of $\mathrm{Ce}-\mathrm{Zr}-\mathrm{O}$ could also explain the dependence of reactivity profiles of internal char on temperature for both steam and $\mathrm{CO}_{2}$ gasification (Figures 5.7 and 5.9). At low temperatures, the rate of gasification was relatively constant throughout the whole conversion range. In contrast, at high temperatures, the rate of gasification decreased significantly with the degree of conversion. Figure 5.12 illustrates the proposed explanation for this behavior. Before reaction (top image) part of the char is in intimate contact with the Ce-Zr-O particles. Due to the high catalytic activity of Ce-Zr-O, the char in close contact with the catalyst particles will be the first to react away. As a result, the catalyst pores will start to retrieve their porosity and the remaining char will be submitted to forces due to tension which will induce break up of the initial char structure, resulting in smaller char-catalyst interface. It was shown that catalytic gasification is much faster than the analogous noncatalytic and therefore poorer contact between the char and the catalyst will result in a decrease in gasification rate with increasing conversion. As proposed in Figure 5.12, char gasified at high temperatures (bottom left image) results in a more abrupt decrease in char-catalyst interface than char gently gasified at lower temperatures (bottom right image), resulting in a decrease in the rate of gasification with increasing the degree of conversion to a larger extent than at lower temperatures. 


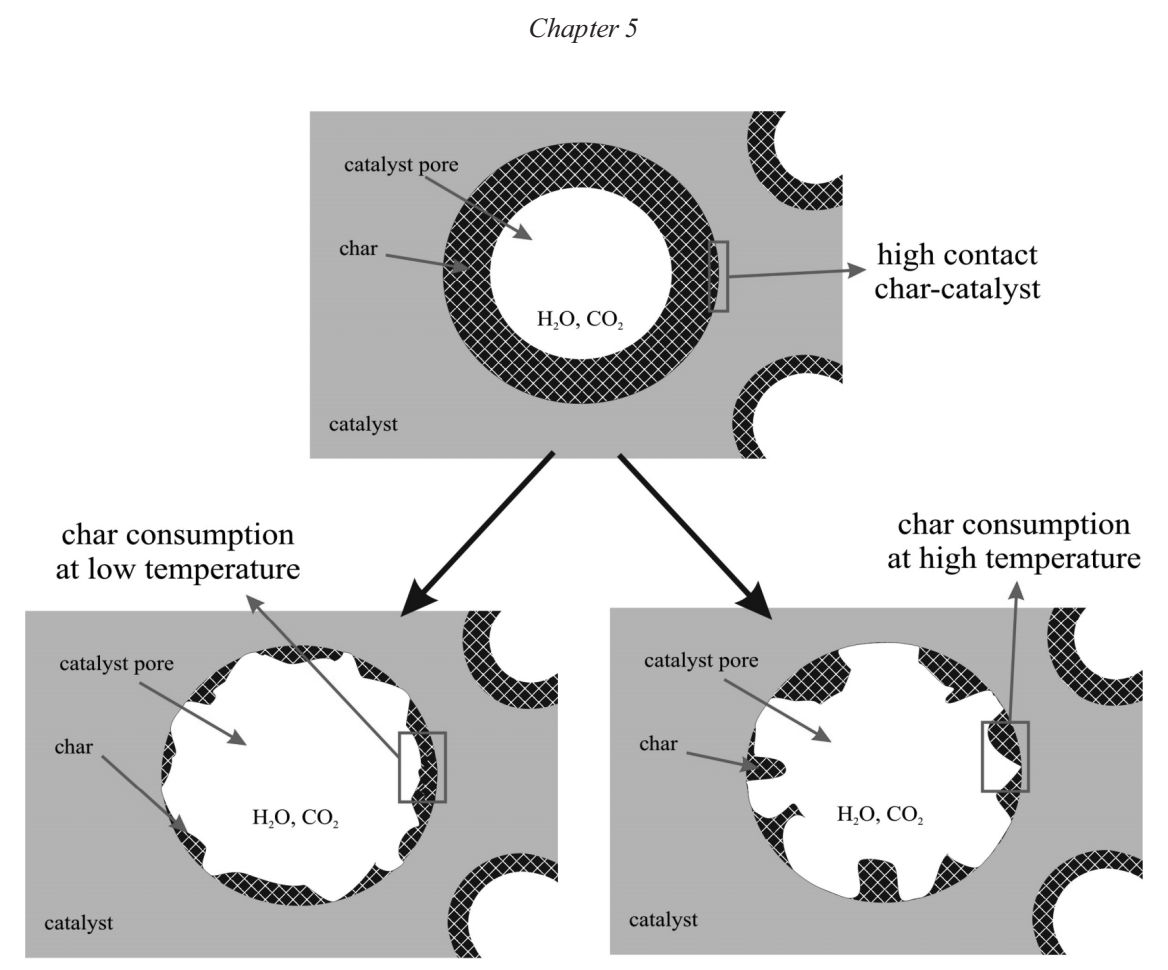

Figure 5.12. Proposed explanation for the dependence of char reactivity profiles on temperature. Char deposited on porous Ce-Zr-O before reaction (top) and char consumption at high temperatures (bottom left) and low temperatures (bottom right).

Based on the obtained results, Figure 5.13 illustrates the possible paths involved in steam and $\mathrm{CO}_{2}$ char gasification in the presence and absence of $\mathrm{Ce}-\mathrm{Zr}-\mathrm{O}$.

$\mathrm{C}^{*} \equiv$ higher stability carbon

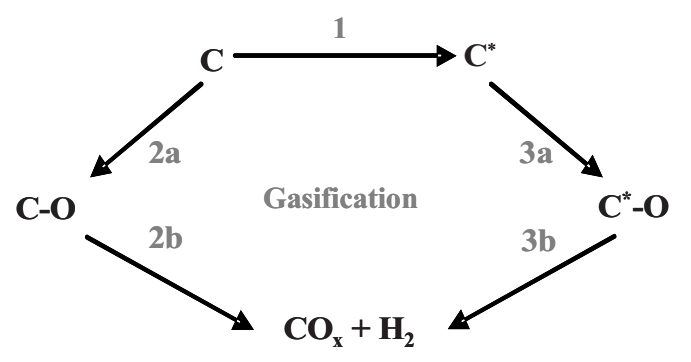

Figure 5.13. Proposed mechanism for $\mathrm{CO}_{2}$ and steam gasification of char derived from pyrolysis oil. 
Char gasification occurs mainly via two parallel routes. On one hand, the initial char, which is slightly oxygenated, here referred as $C$, is first converted to more reactive intermediates (further oxygenated char), here denoted as $C-O$ (route $2 \mathrm{a}$ ), which react further to lead to the end products $\left(\mathrm{CO}_{\mathrm{x}}+\mathrm{H}_{2}\right)$ (route $2 \mathrm{~b}$ ). As discussed earlier, pyrolysis oil evaporation in the presence of $\mathrm{Ce}-\mathrm{Zr}-\mathrm{O}$ resulted in the generation of more oxygenated char (C-O bond type species). Therefore, according to the proposed scheme, Ce-Zr-O facilitates the pre-steps involved in char gasification (route 2a), explaining, to a certain extent, the enhancement in char reactivities.

In Chapter 4 on noncatalytic steam gasification, we concluded that, similar to coal gasification [40], part of the initial char undergoes a gradual transformation (aging process) towards a hydrogen and oxygen lean type of char, denoted as $\mathrm{C}^{*}$, which can be accompanied by devolatilization. This results in a more stable and thus less reactive char (route 1). It was further concluded that devolatilization is favored at high temperatures. In the present study, char on the catalyst was produced at $750{ }^{\circ} \mathrm{C}$. According to the noncatalytic results, at this temperature, devolatilization should have already occurred to a large extent. Therefore, further devolatilization during catalytic $\mathrm{CO}_{2}$ and steam gasification is expected to occur only marginally. Similar to the analogous route described for the initial char, the aged char, $\mathrm{C}^{*}$, is further converted to more reactive oxygenate intermediates, represented as $C^{*}-O$, (route 3a) which are gasified to $\mathrm{CO}_{\mathrm{x}}+\mathrm{H}_{2}$ (route $3 \mathrm{~b}$ ). Also in this case, $\mathrm{Ce}-\mathrm{Zr}-\mathrm{O}$ is suggested to enhance the route towards formation of oxygenates, resulting in an enhancement in gasification rates.

To summarize, $\mathrm{Ce}-\mathrm{Zr}-\mathrm{O}$ enhanced $\mathrm{CO}_{2}$ and steam gasification of char derived from pyrolysis oil significantly. Based on our observations and discussions addressed in this work, we conclude that this enhancement could be further improved. Two main aspects should be considered for optimization: the catalyst/char contact and the temperature in which char is produced on the catalyst. 


\subsection{Conclusions}

Our findings demonstrate that pyrolysis oil evaporation in combination with internal catalytic char gasification is feasible at relatively low temperatures $\left(\leq 700{ }^{\circ} \mathrm{C}\right)$. This can be explained by the high efficiency of the ceria-zirconia based catalyst to convert char to syngas via catalytic steam $/ \mathrm{CO}_{2}$ gasification at those low temperatures. The role of the $\mathrm{Ce}-\mathrm{Zr}-\mathrm{O}$ catalyst is suggested to provide oxygen for char gasification, resulting in oxygen vacancies, and activate $\mathrm{H}_{2} \mathrm{O}$ and $\mathrm{CO}_{2}$ to regenerate the oxygen vacancies formed. Additionally, Ce-Zr-O facilitates the pre-steps involved in char gasification, by making char more oxygenated and thus more reactive during pyrolysis oil evaporation. It has been shown that a good contact between char and catalyst is essential for the catalytic enhancement in char gasification. The catalyst/pyrolysis oil ratio and the temperature in which char is produced are two aspects to be optimized. 


\section{References}

1. Mullen, C.A.; Boateng A.A. Chemical composition of bio-oils produced by fast pyrolysis of two energy crops. Energy \& Fuels 2008, 22, 2104.

2. Rioche, C.; Kulkarni, S.; Meunier, F.C.; Breen, J.P.; Burch R. Steam reforming of model compounds and fast pyrolysis bio-oil on supported noble metal catalysts. Appl. Catal. B $2005,61,130$.

3. Van Rossum, G.; Matas Güell, B.; Balegedde Ramachandran, R.P.; Seshan, K.; Lefferts, L.; Van Swaaij, W.P.M. ; Kersten, S.R.A. Evaporation of pyrolysis oil: product distribution and residue char analysis. AIChE J. 2009, submitted.

4. Van Rossum, G.; Kersten, S.R.A. ; Van Swaaij, W.P.M. Staged Catalytic Gasification/Steam Reforming of Pyrolysis Oil. Ind. Eng. Chem. Res. 2009, 48, 5857.

5. Van Rossum, G.; Kersten, S.R.A.; Van Swaaij, W.P.M. Catalytic and Noncatalytic Gasification of Pyrolysis Oil. Ind. Eng. Chem. Res. 2007, 46, 3959.

6. Shang Jung, Y.; Wolf, E.E. $\mathrm{K}_{2} \mathrm{CO}_{3}$-catalysed steam gasification of supercritical extracted chars. Fuel 1983, 62738

7. Walker Jr, P.L.; Matsumoto, S.; Hanzawa, T.; Muira, T.; Ismail, I.M.K. Catalysis of gasification of coal-derived cokes and chars. Fuel 1983, 62, 140.

8. Henderson, M.A. The interaction of water with solid surfaces: fundamental aspects revisited. Surface Science Reports 2002, 46, 1.

9. Snoeck, J.W.; Froment, G.F.; Fowles, M. Steam/ $/ \mathrm{CO}_{2}$ Reforming of Methane. Carbon Formation and Gasification on Catalysts with Various Potassium Contents. Ind. Eng. Chem. Res. 2002, 41, 3548.

10. Bruno, G.; Buroni, M.; Carvani, L.; Piero, G.D.; Passoni, G. Water-insoluble compounds formed by reaction between potassium and mineral matter in catalytic coal gasification. Fuel 1988, 67, 67. 
11. Sharma, A.; Kawashima, H.; Saito, I.; Takanohashi, T. Structural Characteristics and Gasification Reactivity of Chars Prepared from $\mathrm{K}_{2} \mathrm{CO}_{3}$ Mixed HyperCoals and Coals. Energy \& Fuels 2009, 23, 1888.

12. Marshall, H.A.; Smits, F.C.R.M. Exxon Catalytic Coal Gasification process and large pilot plant development program. Proceedings - 9th Annual International Conference on coal gasification, liquefaction and conversion to electricity 1982.

13. Tomishige, K.; Asadullah, M.; Kunimori, K. Syngas production by biomass gasification using $\mathrm{Rh} / \mathrm{CeO}_{2} / \mathrm{SiO}_{2}$ catalysts and fluidized bed reactor. Catal. Today 2004, 89, 389.

14. Sharma, S.; Hilaire, S.; Vohs, J.M.; Gorte, R.J.; Jen, H.W. Evidence for Oxidation of Ceria by $\mathrm{CO}_{2}$. J. Catal. 2000, 190, 199.

15. Matas Güell, B.; Babich, I.; Nichols, K.P.; Gardeniers, J.G.E.; Lefferts, L.; Seshan, K. Design of a stable steam reforming catalyst - A promising route to sustainable hydrogen from biomass oxygenates. Appl. Catal. B 2009, 90, 38.

16. Oasmaa, A.; Sipila, K.; Solantausta, Y.; Kuoppala, E. Quality Improvement of Pyrolysis Liquid: Effect of Light Volatiles on the Stability of Pyrolysis Liquids. Energy \& Fuels $2005,19,2556$

17. Schuurman, Y.; Marquez-Alvarez, C.; Kroll, V.C.H.; Mirodatos, C. Unraveling mechanistic features for the methane reforming by carbon dioxide over different metals and supports by TAP experiments. Catal. Today 1998, 46, 185.

18. Oku, M.; Suzuki, S.; Ohtsu, N.; Shishido, T.; Wagatsuma, K. Comparison of intrinsic zero-energy loss and Shirley-type background corrected profiles of XPS spectra for quantitative surface analysis: Study of Cr, Mn and Fe oxides. Appl. Surface Science 2008, 254,5141 .

19. Sing, K.S.W. Reporting physisorption data for gas solid systems - with special reference to the determination of surface area and porosity. Pure Appl. Chem. 1982, 54, 2201. 
20. Beamson, G.; Briggs, D. High Resolution XPS of Organic Polymers: The Scienta ESCA300 Database. John Wiley \& Sons, Chichester, 1992.

21. Moulder, J.F.; Stickle, W.F.; Sobol, P.E.; Bomben, K.D. Handbook of X-ray Photoelectron Spectroscopy. Perkin-Elmer Corporation, Eden Prairie, 1992.

22. Sharanda, L.F.; Plyuto, Y.V.; Babich, I.V.; Plyuto, I.V.; Shpak, A.P.; Stoch, J.; Moulijn, J.A. Synthesis and characterisation of hybrid carbon-alumina support. Appl. Surface Science 2006, 252, 8549 .

23. McKee, D.W. Rare earth oxides as carbon oxidation catalysts. Carbon 1985, 23, 707.

24. Nagaoka, K.; Seshan, K.; Takanabe, K.; Aika, K.I. Improvement of Pt/ZrO $\mathrm{Z}_{2}$ by $\mathrm{CeO}_{2}$ for high pressure $\mathrm{CH}_{4} / \mathrm{CO}_{2}$ reforming. Catal. Letters 2005, 99, 97.

25. Padeste, C.; Cant, N.W.; Trimm, D.L. The influence of water on the reduction and reoxidation of ceria. Catal. Letters 1993, 18, 305.

26. Fu, Q.; Saltsburg, H.; Flytzani-Stephanopoulos, M. Active Nonmetallic Au and Pt Species on Ceria-BasedWater-Gas Shift Catalysts. Science 2003, 301, 935.

27. Jacobs, G.; Williams, L.; Graham, U.; Sparks, D.; Davis, B.H. Low-Temperature WaterGas Shift: In-Situ Reaction Study of a $\mathrm{Pt} / \mathrm{CeO}_{2}$ Catalyst for Fuel Cell Reformer Applications. J. Physical Chem. B 2003, 107, 10398.

28. Meunier, F.C.; Tibiletti, D.; Goguet, A.; Reid, D.; Burch, R. On the reactivity of carbonate species on a $\mathrm{Pt} / \mathrm{CeO}_{2}$ catalyst under various reaction atmospheres: Application of the isotopic exchange technique. Appl. Catal. A 2005, 289, 104.

29. Hamilton, R.T.; Sams, D.A.; Shadman, F. Variation of rate during potassium-catalysed $\mathrm{CO}_{2}$ gasification of coal char. Fuel 1984, 63, 1008.

30. Domazetis, G.; Liesegang, J.; James, B.D. Studies of inorganics added to low-rank coals for catalytic gasification. Fuel Processing Technology 2005, 86, 463. 
31. Otake, Y.; Walker Jr, P.L. Pyrolysis of demineralized and metal cation loaded lignites. Fuel 1993, 72, 139.

32. Takarada, T.; Sasaki, J.; Otsuka, Y.; Tamai, Y.; Tomita, A. Direct production of high British Thermal Unit gas from the low-temperature steam gasification of brown coal. Ind. Eng. Chem. Res. 1987, 26, 627.

33. Kustov, A.L.; Frey, A.M.; Larsen, K.E.; Johannessen, T.; Nørskov, J.K.; Christensen, C.H. CO methanation over supported bimetallic Ni-Fe catalysts: From computational studies towards catalyst optimization. Appl. Catal. A 2007, 320, 98.

34. Haffad, D.; Chambellan, A.; Lavalley, J.C. Propan-2-ol transformation on simple metal oxides $\mathrm{TiO}_{2}, \quad \mathrm{ZrO}_{2}$ and $\mathrm{CeO}_{2}$. J. Molecular Catal. A 2001, 168, 153.

35. Sadi, F.; Duprez, D.; Gérard, F.; Miloudi, A. Hydrogen formation in the reaction of steam with $\mathrm{Rh} / \mathrm{CeO}_{2}$ catalysts: a tool for characterising reduced centres of ceria. J. Catal. 2003, $213,226$.

36. Vlaic, G.; Di Monte, R.; Fornasiero, P.; Fonda, E.; Kaspar, J.; Graziani, M. Redox Property-Local Structure Relationships in the Rh-Loaded CeO2-ZrO2 Mixed Oxides. $J$. Catal. 1999, 182, 378.

37. Pis, J.J.; Menéndez, J.A.; Parra, J.B.; Álvarez, R. Relation between texture and reactivity in metallurgical cokes obtained from coal using petroleum coke as additive. Fuel Processing Technology 2002, 77-78, 199.

38. Arias, B.; Pevida, C.; Rubiera, F.; Pis, J. Changes in coal char reactivity and texture during combustion in an entrained flow reactor. J. Thermal Analysis and Calorimetry $2007,90,859$.

39. Azzam, K.G.; Babich, I.V.; Seshan, K.; Lefferts, L. Bifunctional catalysts for single-stage water-gas shift reaction in fuel cell applications.: Part 1. Effect of the support on the reaction sequence. J. Catal. 2007, 251, 153.

40. Tyler, R.J. Flash pyrolysis of coals. 1. Devolatilization of a Victorian brown coal in a small fluidized-bed reactor. Fuel 1979, 58, 680 . 


\section{Outlook}

Pyrolysis oil has the potential to become the 'sustainable crude oil'. With fast pyrolysis, biomass (waste) streams are standardized in such a way that the current heat and power and petrochemical industry can start to replace part of their conventional fossil feedstocks with a green alternative in (modified) current and new to be developed processes.

One of the important processes to convert pyrolysis oil, its fractions or other bioliquid streams will be steam reforming to produce syngas/hydrogen. In this Thesis, a start has been made to develop a reactor and a process which can adequately reform reactive bioliquids. By splitting the process in first an evaporation section followed by the catalytic conversion of vapors and gases, both processes could be optimized separately. The steam reforming catalyst has to be optimized on activity and does not need the mechanical strength for fluidization anymore which was shown to be a main reason for catalytic deactivation in this work and work done by others. The evaporation of the pyrolysis oil can be done at a lower temperature and can be optimized for minimizing char formation and/or making sure that the char is deposited on (active) materials for further conversion. According to the author, the following research and technical questions remain which need to be addressed:

- How stable are commercially available and newly developed catalysts for actual pyrolysis oil reforming. Immediate catalyst deactivation (due to sintering/attrition) does now not occur but commercial expected catalyst lifetimes must now be estimated. How do for instance trace impurities like sulfur and chlorides affect the catalyst activity? Another important issue is coke buildup control. 
- A start has been made to investigate the evaporation behavior of pyrolysis oil and very interesting results have been obtained, especially related to char formation. It will be important to investigate this further and combine it with controlled contacting of the pyrolysis oil with (catalytically active) particles.

- The products syngas and hydrogen are used in further processes at elevated pressures. Due to the high cost of pressurizing gas and equipment size considerations it is preferable to also pressurize the whole steam reforming process. Compared to other biomass thermo-chemical conversion processes pyrolysis oil reforming is 'easy' to pressurize since a liquid is used as a reactant. However, in this work it was shown that the evaporation step is very important in steering the initial product distribution. Since evaporation is probably pressure dependant it is important to study its impact.

- Up till now, research has been done on available pyrolysis oils. It will be very interesting to see whether it is possible to avoid optimization of the processes of fast pyrolysis and steam reforming separately but to look for an integrated optimization of the conversion chain possibly with other upgrading technologies (like hydrodeoxygenation) to come to full biorefinery concepts.

With the obtained results a reliable economic evaluation can be made for upscaling of this technology to pilot scale and eventually for commercial operation. It is foreseen that this technology would initially find its application as an add-on technology to already existing steam reformers. In this way, market implementation barriers (like a high capital investment) are lowered and already existing petrochemical/oil companies can readily make their conversion chain more sustainable. However, the overall route of biomass (waste) to hydrogen/synthesis gas needs to be well analyzed since a widely decentralized market (e.g. farmers and forestry) has to be linked to a strongly centralized one. 


\section{Appendix I}

Steam Reforming of Vapors/Gases Released during Commercial Charcoal Production 


\section{A.I.1 Introduction}

During the production of charcoal from wood, a lot of energy is being released in the form of vapors and gases. These vapors and gases are usually combusted to supply heat for the process and to dry the feedstock. However, still an excess amount of heat is released which is not utilized.

To utilize the excess heat, three solutions are proposed to convert the whole or part of the vapor/gas stream:

(i) Direct combustion and use a steam cycle to coproduce electricity.

(ii) Onsite steam reforming of the vapors and gases to produce a low tar gas which can be (co-)combusted to produce electricity (e.g. in gas or diesel engines) and heat for the process.

(iii) Condensation of part of the vapors produced and use this oil on site or as a commodity energy carrier for centralized combustion or steam reforming.

Option (i) can in principle be applied since the technology is readily available. However, usually large facilities ( $>1 \mathrm{MW}$ ) are necessary to have favorable economics. For (ii) and (iii), the feasibility of steam reforming such streams still has to be investigated. In this Appendix, steam reforming of a side vapor/gas stream of a commercial charcoal production facility is reported, namely of one of the Twin Retorts of Carbo, The Netherlands.

This Twin Retort technology [1] is based on semi batch charcoal production using two retorts, which is illustrated in Figure A.I.1. One retort is charged with wood and placed inside an oven. This retort heats up and the wood starts to dry, releasing a large amount of steam. When the wood temperature is sufficiently high $\left(>200{ }^{\circ} \mathrm{C}\right)$, carbonization of the wood starts and besides steam also permanent gases and vapors are released. With a further temperature increase, the rate of carbonization increases rapidly. In this stage, significant amounts of vapor/gas are being produced with a high heating value. By operating two retorts in counter-phase, combustion of the vapors/gases released by one retort can supply enough heat for both retorts and even a surplus heat is available. 
To analyze the potential of steam reforming (part of) the vapors/gases produced during carbonization the following analysis are made:

- First the temperature is measured at various points of the retort to see how they fluctuate during the process.

- An analysis is made of the amounts of vapors and gases (and composition) which are being released.

- The gases and vapors of one retort (side stream) are steam reformed.

\section{A.I.2 Analysis of the Twin Retort Carbonization Process: Temperature}

As a first part of the examination, thermocouples were placed inside the twin retort in order to follow temperature variations during operation at the following locations:

- Inside the oven where the released gases and vapors are combusted.

- Against the outside steel wall of the vessels (A and B).

- Inside the vapor outlet of the vessel.

Figure A.I.1 shows a schematic representation of the Twin Retort process and where the temperatures are measured.

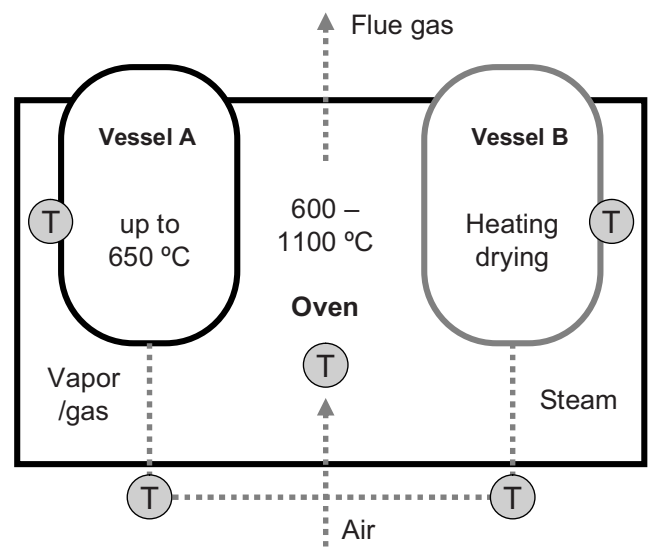

Figure A.I.1. Schematic representation of the Twin Retort for the semi-batch wise production of charcoal. 
Figure A.I.2 shows typical measured temperatures over a full day of operation. What can be clearly seen is that all temperatures vary in time. The most important observation is that the temperature of the released vapor/gas streams is maximally $500{ }^{\circ} \mathrm{C}$ which indicates that the vapor fraction will be in the range of $\sim 70 \mathrm{wt} \%$ (see Chapters 2 and 4).

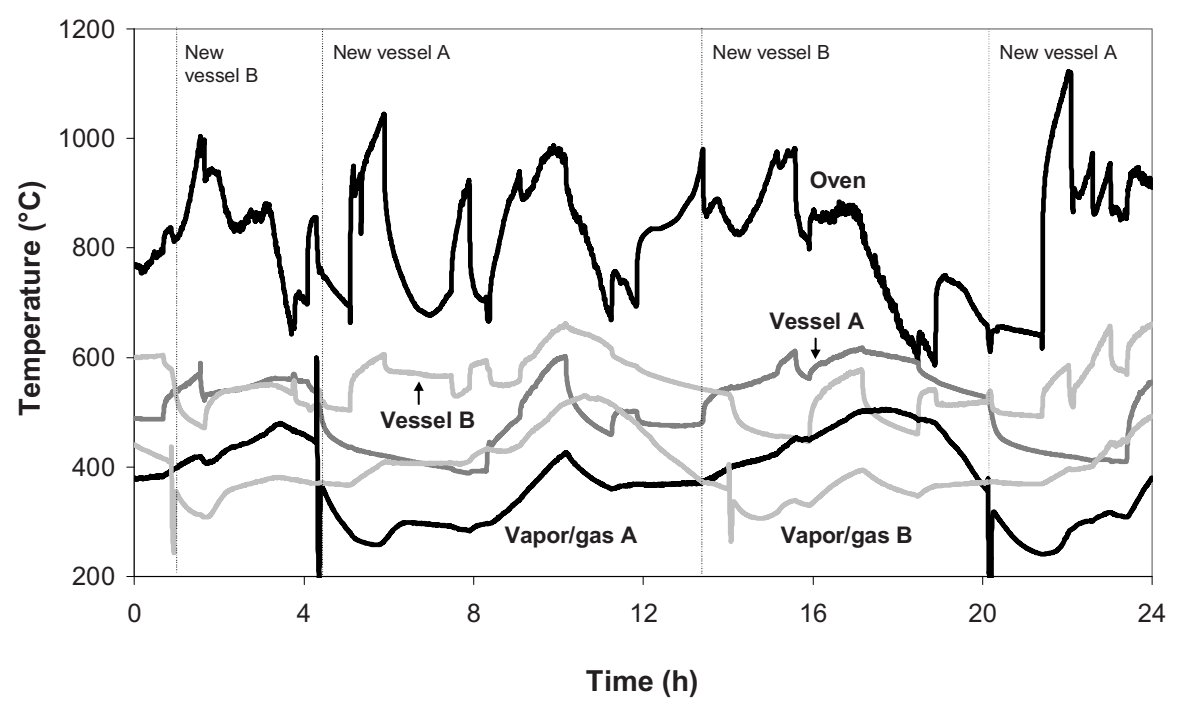

Figure A.I.2. Measured temperatures of the oven, vessels (A and B) and vessel outlets (Vapor/gas A+B) of a Twin Retort over a full day of operation.

Sequential vessel changes are indicated.

\section{A.I.3 Vapor collection and vapor/gas analysis}

To measure the global mass and component balances of the process, the following measurement equipment has been installed at one of the vessels (B) of the retort:

- A balance was fitted on top of the vessel. The vessel hangs freely inside the oven of the retort and is made leak tight using a sand lock. The weight of the vessel could be continuously measured. 
- A small amount of the vapors/gases $(\sim 2 \%)$ is drawn from the exit line using a membrane pump. The vapors and water are condensed using an externally cooled spraying column. The residual gas is filtered; the flow and the gas composition are measured using a micro GC.

Figure A.I.3 shows a schematic overview of the Twin Retort with the measurement equipment.

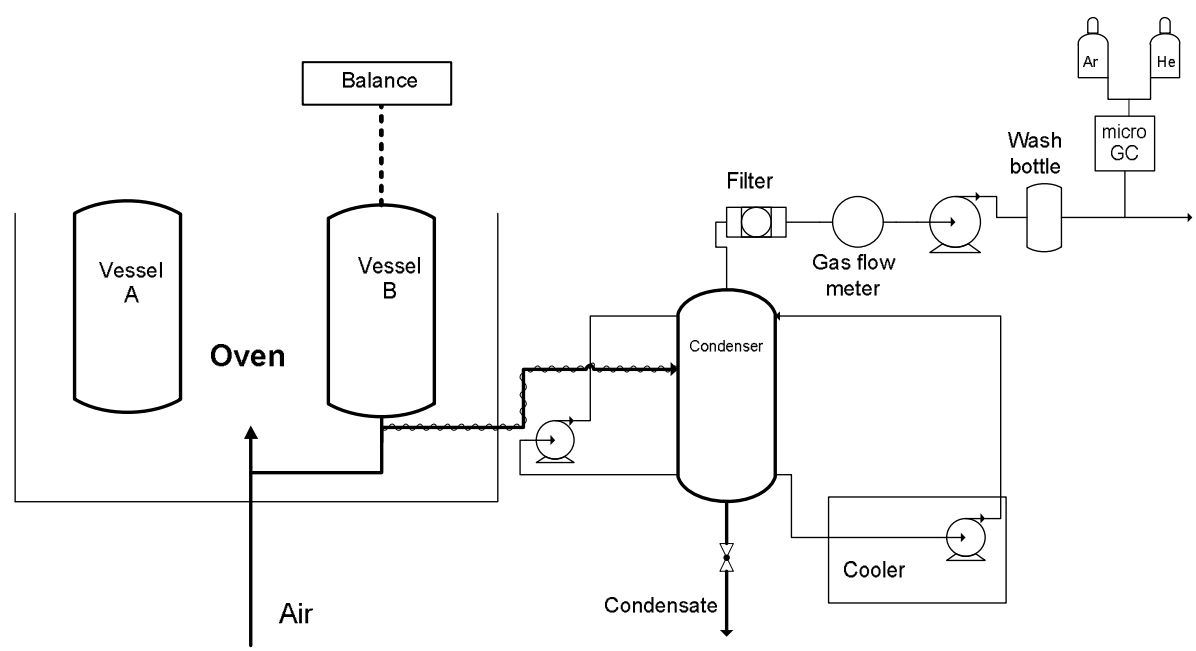

Figure A.I.3. Twin Retort and measurement equipment for analyzing the global mass and component balance.

Figure A.I.4 shows the (A) permanent gas composition, (B) temperature, and (C) weight loss of the vessel. Two phases can be identified in the conversion, namely a drying phase and a pyrolysis/carbonization phase.

\section{Drying}

In the first 4 hours of the experiment, the wood is mainly dried which releases large amounts of water and small amounts of gas (mainly $\mathrm{CO}_{2}$ and $\mathrm{CO}$ ). The temperature of the outgoing vapors/gases is quite low (see Figure A.I.4B) because most of the ingoing energy is used for the evaporation of water. 


\section{Pyrolysis/Carbonization}

After the initial drying, carbonization of the wood starts. Large amounts of vapors and gases are being released (see Figure A.I.4C) and the temperature increases steadily since less heat is necessary for the pyrolysis reaction than for the evaporation of the water. The temperature rise further enhances the carbonization process and the weight loss rate increases till the point that most of the wood is converted to charcoal. The weight loss rate then decreases finalizing the production of charcoal with an overall weight yield of $46 \%$ (wet biomass basis). During the carbonization of the wood, the gas composition was measured continuously and the condensed vapors periodically. On average, the vapor fraction in the vapor/gas stream is $70 \mathrm{wt} \%$ in the time span of $7.5-10 \mathrm{~h}$.

(A)

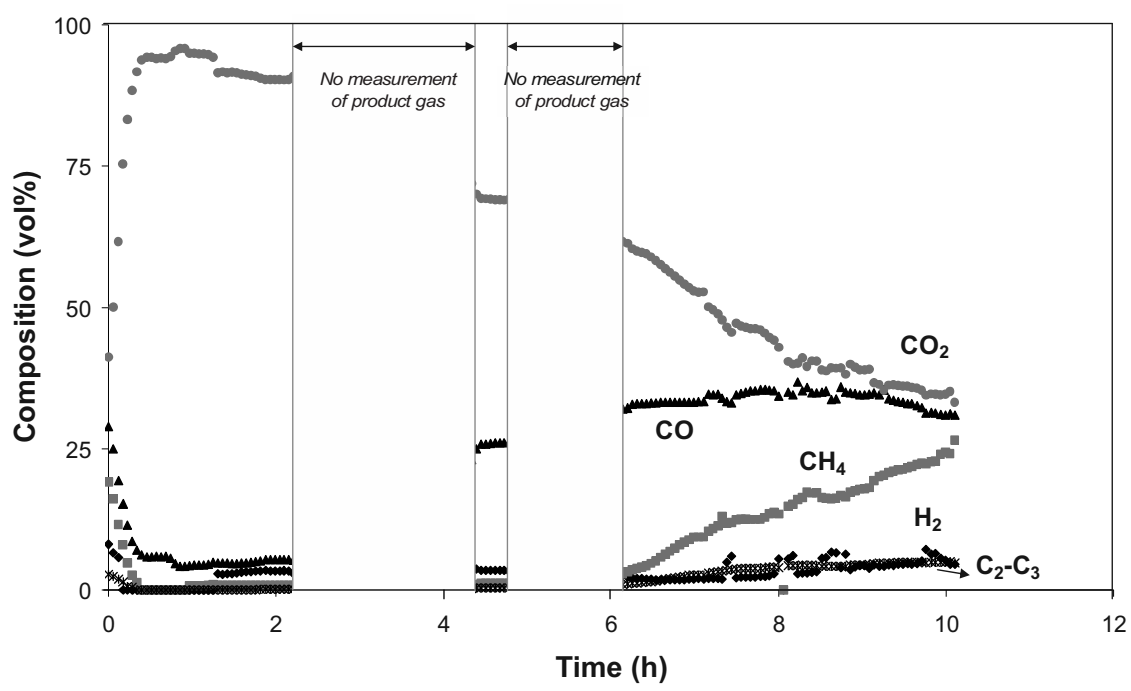


(B)

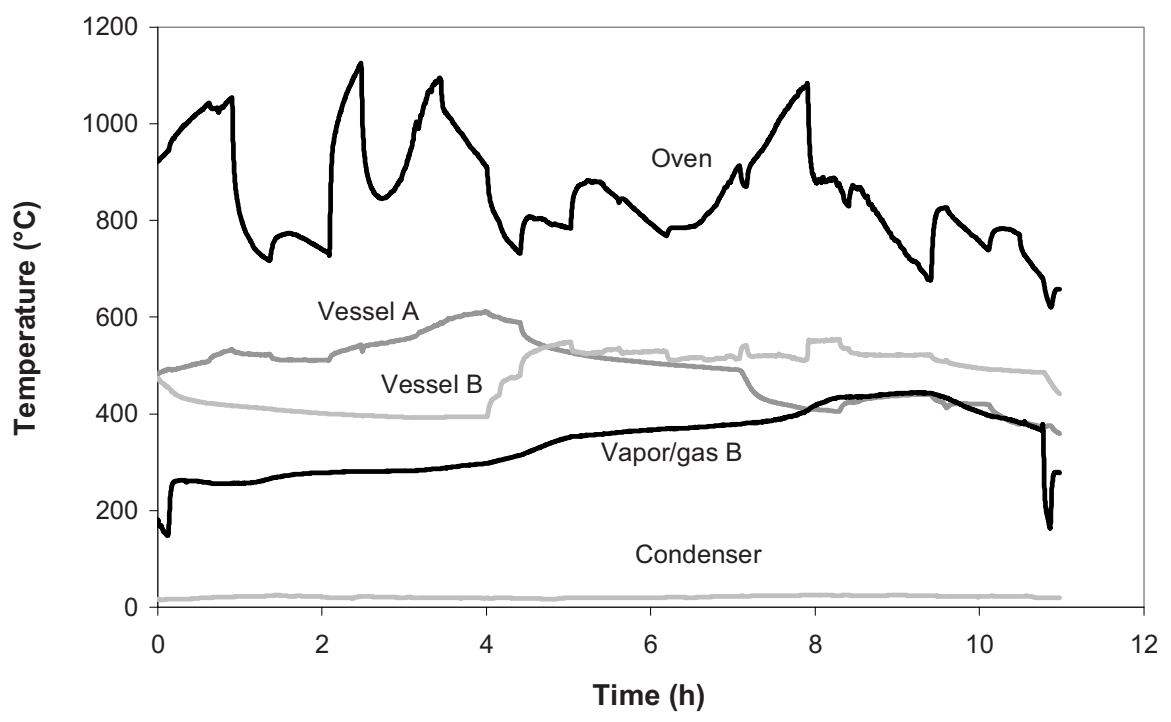

(C)

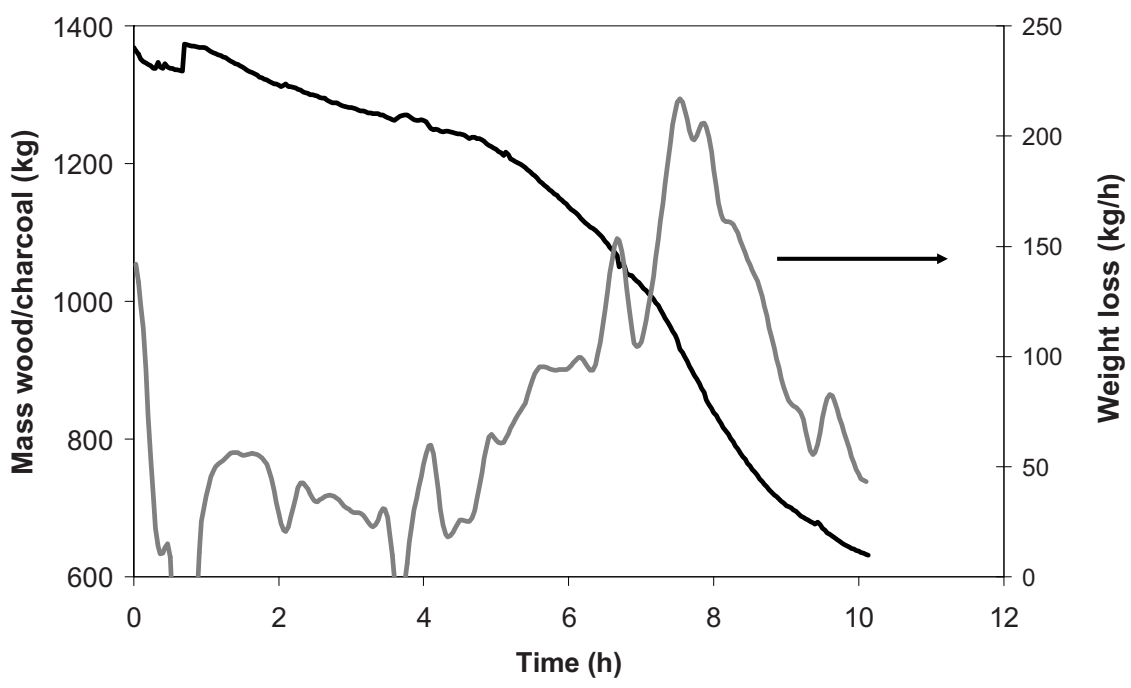

Figure A.I.4. Results of single vessel conversion. (A) permanent gas composition, (B) temperature, (C) mass wood/charcoal and weight loss. 


\section{A.I.4 Catalytic conversion of the vapors to permanent gases}

In order to examine the steam $/ \mathrm{CO}_{2}$ reforming of the vapors (and gases) which come from a single Twin Retort vessel, a catalytic fixed bed reactor was placed between the condenser section and sampling point of the vessels exit; the whole analysis section (condenser, balance, micro-GC) was kept essentially the same as is illustrated in Figure A.I.5. The reactor consisted of two parts; at the beginning a heating section was installed which was filled with alumina and the second part the catalyst itself (operated at $850{ }^{\circ} \mathrm{C}$ ). The catalyst used was a commercial fixed bed steam reforming catalysts for naphtha conversion which consists of nickel on alumina and some other promoters (see Chapters 2 and 3$)$.

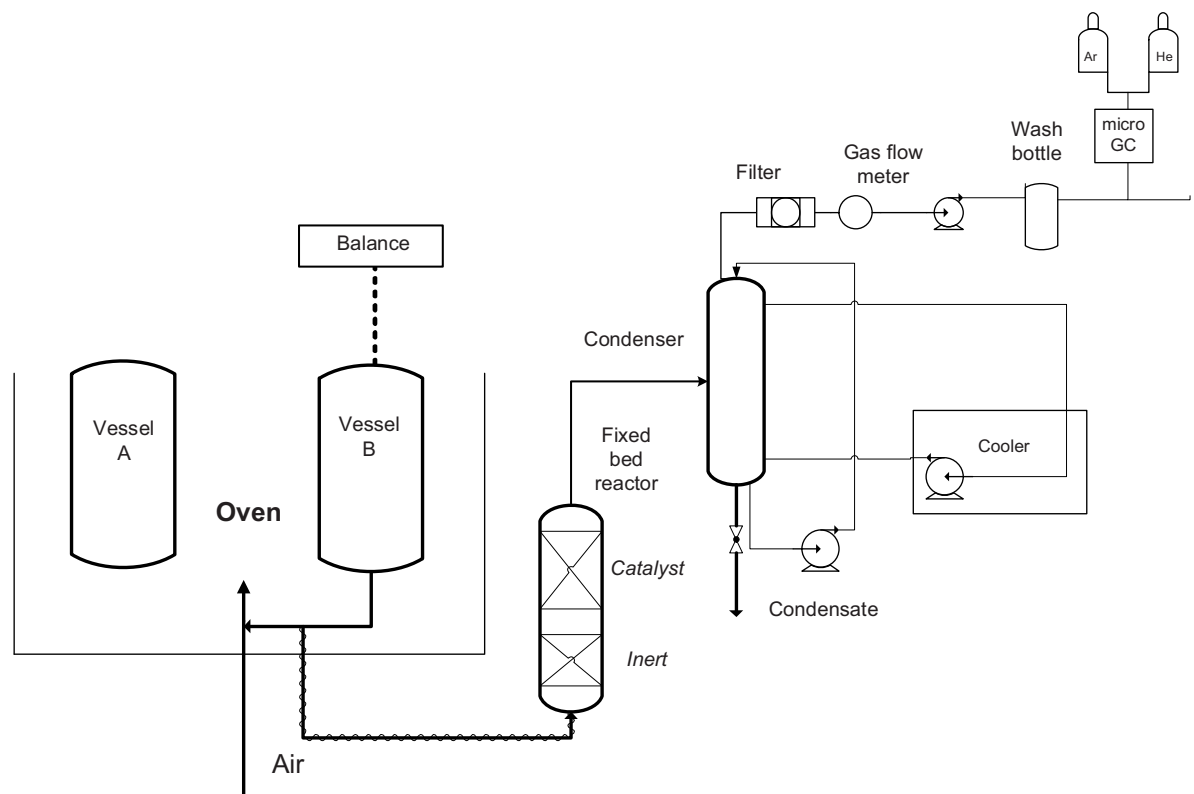

Figure A.I.5. Twin Retort to which a (steam/ $/ \mathrm{CO}_{2}$ ) reforming reactor was coupled and the measurement equipment for analyzing the global mass and component balance.

Figure A.I.6 shows the (A) permanent gas composition of major gases $\left(\mathrm{H}_{2}, \mathrm{CO}\right.$, and $\left.\mathrm{CO}_{2}\right)$, (B) permanent gas composition of minor gases $\left(\mathrm{CH}_{4}\right.$ and $\left.\mathrm{C}_{2}-\mathrm{C}_{3}\right)$, and $(\mathrm{C})$ weight loss of the vessel. The concentrations were measured only during the carbonization phase 
since the catalyst needs activation with hydrogen before usage and exposing the catalyst only to steam (released during drying) would oxidize the catalyst.

The gas/vapor stream fed to the reformer is similar to the feeds tested in Chapter 3 with atomizer temperatures around $500{ }^{\circ} \mathrm{C}$ ( $\sim 70 \mathrm{wt} \%$ vapor, $\sim 30 \mathrm{wt} \%$ gas).

Over the whole period measured, the condensate collected after the reformer was colorless which indicates that (almost) no vapors came through the catalytic bed but that they were converted to permanent gases. The gas composition changes in time with carbon monoxide and methane (although very low) rising and carbon dioxide lowering. The percentage of hydrogen was more or less constant over the period measured. The observed increasing methane slip can be explained by the following:

- More methane is fed to the reactor in time which leads to a incomplete conversion.

- The amount of water (and $\mathrm{CO}_{2}$ ) fed to the reformer decreases during carbonization; they are however essential for the reformer to work properly and reach full methane conversions. An indication during the measurement that there was a shortage of water was that during pyrolysis no or hardly no condensate was collected. To overcome this problem the reformer should be connected to both vessels where one is drying (releasing water) and one is carbonizing.

- Catalyst deactivation takes place. Catalyst deactivation can take place both reversible and irreversibly. If catalyst deactivation was the cause for the methane slip, it was irreversible deactivation since the catalyst regained its full conversion in consecutive experiments. However, irreversible catalyst deactivation can occur after long term operation.

Some carbon was found in the reformer reactor which probably could have been minimized by increasing the steam flow to the reactor. 
(A)

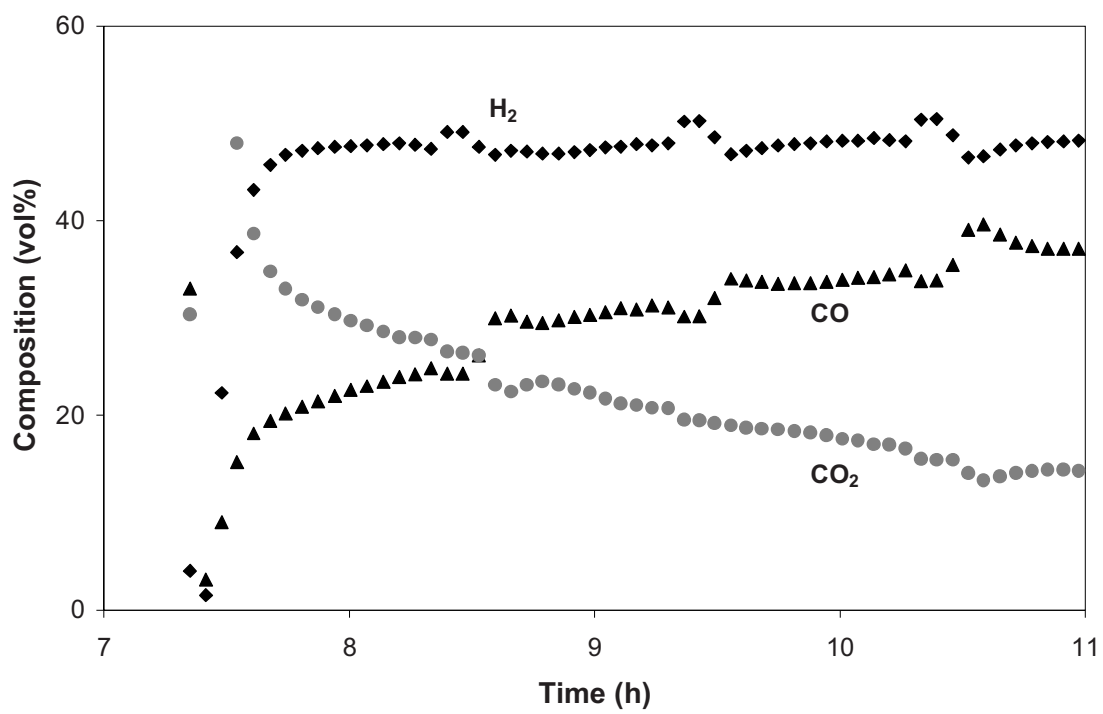

(B)

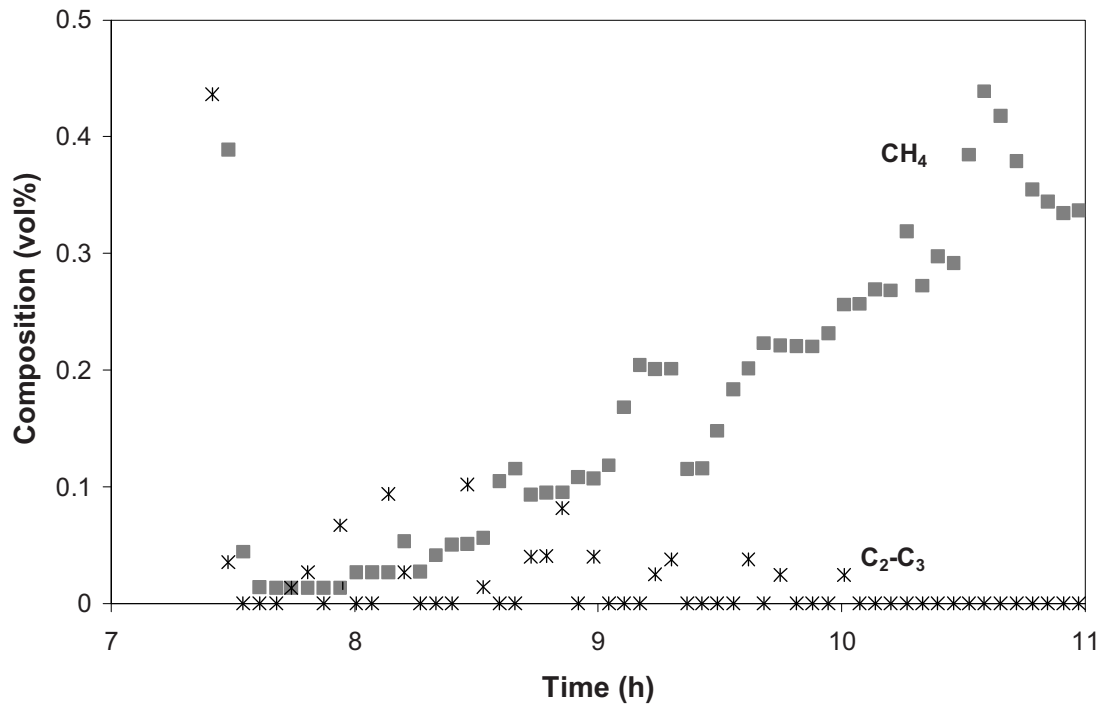


(C)

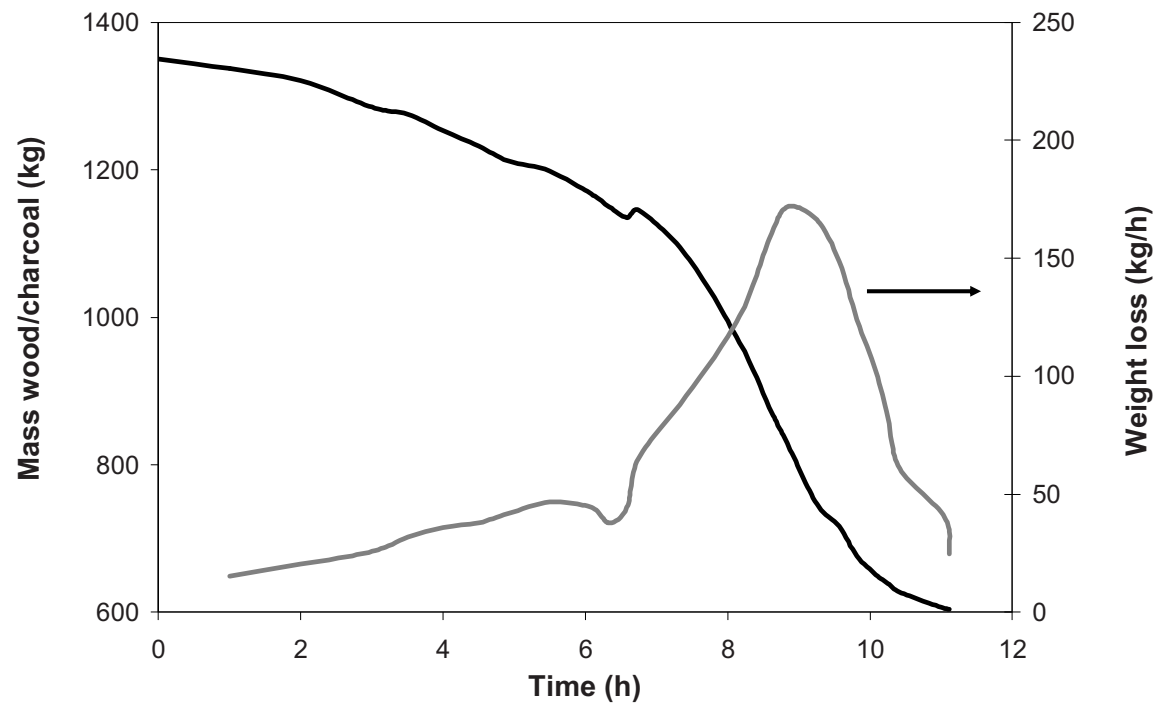

Figure A.I.6. Results of single vessel conversion where the side stream is led over a reformer reactor. (A) permanent gas composition, (B) temperature,

(C) mass wood/charcoal and weight loss.

\section{A.I.5 Summarizing}

The permanent gases and vapors which have been released during the charcoal production in a Twin Retort can be converted into a gas which is rich in hydrogen, carbon monoxide and carbon dioxide. Only low amounts of methane have been measured which, when electricity generation is envisaged, would not create a problem since it can be combusted evenly well as the hydrogen and carbon monoxide. Visual analysis of the condensate indicates that the tar level in the gas will be low.

\section{Reference}

1. Reumerman, P.J.; Frederiks, B. Charcoal production with reduced emissions. Proceedings of the $12^{\text {th }}$ European Conference on Biomass for Energy, Industry and Climate Protection, Amsterdam, The Netherlands, 2002. 


\title{
Appendix II
}

\author{
System Configurations for the Conversion \\ of Pyrolysis Oil to Fuel Cell Electricity
}

\begin{abstract}
In this Appendix, three system configurations of a fuel processor are presented, which can convert pyrolysis oil into fuel cell electricity. Such a fuel processor consists of: a pyrolysis oil gasifier, gas cleaning, and a fuel cell plus afterburner. The analysed systems differ in gasifier type, fuel cell type (molten carbonate and solid oxide), and recycle strategy. Modelling was done using Aspen plus $11.1 \AA^{\circledR}$ software, and pinch composite diagrams were constructed to analyze the energy flows in the system for the possibility of heat integration and self-sustaining operation. Simulations show that, when using a SOFC in combination with a pyrolysis oil reformer, an overall efficiency from pyrolysis oil to electricity of over $50 \%$ can be reached.
\end{abstract}

Adapted from:

Van Rossum G., Kersten S.R.A., Prins W., Van Swaaij W.P.M. 2nd World Conference for Energy, Industry and Climate Protection, 10-14 May 2004, Rome, 1179. 


\section{A.II.1 Introduction}

A future application of pyrolysis oil gasification is the combination with decentralized stationary electricity production (ca. $500 \mathrm{~kW}$ ) using high temperature fuel cells [1]. The most important advantage of this kind of system is that a very high overall electric efficiency (ca. 50\%) can be attained compared to other systems like an internal combustion engine (ca. 30\%), a micro-turbine (ca. 25\%) and a gas turbine (ca. 35\%) [2]. In addition, heat is available at high temperatures, which can be used effectively.

In this Appendix, the basic mass and energy balances of the proposed system (pyrolysis oil gasification integrated with high temperature fuel cells) are presented to validate its feasibility to operate on a self-sustaining basis while achieving an overall high electric efficiency.

\section{A.II.2 System description}

The proposed system for converting pyrolysis oil to fuel cell electricity consists of the following processes (an example of such a system is shown in Figure A.II.1):

- Gasifier: pyrolysis oil to fuel gas conversion

The pyrolysis oil is gasified to a $\mathrm{H}_{2}, \mathrm{CO}, \mathrm{CO}_{2}, \mathrm{H}_{2} \mathrm{O}$, and $\mathrm{CH}_{4}$ containing gas mixture, which can be used as a fuel in high temperature fuel cells. Various gasification reactions can be used for this conversion, examples are: steam, dry and autothermal reforming and partial oxidation. By introducing a catalyst into the system, the temperature is kept at a moderate level $\left(600-900{ }^{\circ} \mathrm{C}\right)$. Because pyrolysis oil is unstable and forms char (coke) upon heating, it must be added to the gasifier at room temperature to prevent blockage problems [3].

- Product gas purification

A hot gas clean-up system must, most probably, be installed between the gasifier and the fuel cell, due to the high constrains of the fuel cells [2] relative to the level of contaminants in the feed. For this purpose the gas from the gasifier is cooled for cleaning and reheated before entering the fuel cell. 
Appendix II

- Electricity production in high temperature fuel cells

When stationary electricity production is considered, high temperature fuel cells have a few distinct advantages over low temperature fuel cells:

- The electric efficiency of the fuel cell is higher.

- The energy, which is not converted to electricity, is released as heat at an attractive temperature $\left(600-1000{ }^{\circ} \mathrm{C}\right)$. This heat can be used elsewhere in the system, whereas when low temperature fuel cells are used, the heat is not available for integration and has to be removed from the system by cooling.

- The fuel cell can convert, besides $\mathrm{H}_{2}, \mathrm{CO}$ via the water gas shift reaction and $\mathrm{CH}_{4}$ via internal reforming. Hence, no high shift towards $\mathrm{H}_{2}$ production has to be attained.

- The impurity restrictions are less severe.

Two high temperature fuel cells are being developed and are near commercialization, namely the Molten Carbonate Fuel Cell (MCFC) and the Solid Oxide Fuel Cell (SOFC)

- Oxidation: burning of residual fuel

Because not all the fuel can be converted in the fuel cell (ca. $75 \%$ can be converted), a lean fuel gas mixture exits the anode of the fuel cell, which is burned to provide additional heat for the system.

Three alternative systems have been analyzed:

System A: Steam reforming coupled with a MCFC (see Figure A.II.1)

This system was also actually developed, built, and tested in the Bio-electricity project (ENK5 CT2002-00634) for which this process analysis was made. Steam is generated and added to the gasifier for the reforming of the pyrolysis oil towards a hydrogen rich gas. Steam reforming has been chosen as the reaction because it can attain a high efficiency towards gas production and is known to give less carbon formation compared to, for instance, partial oxidation. A MCFC fuel cell is being used for the electricity production, since this fuel cell is in a further commercial development stage compared to the SOFC and operates at a lower temperature (ca. $650{ }^{\circ} \mathrm{C}$ versus ca. $950^{\circ} \mathrm{C}$ ), which make the materials of construction cheaper. The system contains, except for the fuel cell, no recycles, which could make the operation of this system easier. 
System B: Combined steam and dry reforming coupled with a SOFC (see Figure A.II.2)

In this system, anode off-gas from the fuel cell is recycled back to the gasifier for the reforming of pyrolysis oil. A clear advantage of this system is that, except for the pyrolysis oil and the air for the fuel cell, no extra reactants are needed for this system and that heat is easily transported to the gasifier in the form of high temperature gases from the fuel cell. Additionally, part of the fuel, which was not converted inside the fuel cell, is recycled back to the reformer allowing an overall higher fuel conversion. Because a SOFC is being used, the heat is released at a higher temperature allowing easier heat integration compared to a MCFC. The high temperature of the recycle stream and the overall high temperature operation will probably make the system more expensive and relatively complex to operate.

\section{System C: Partial oxidation coupled with a MCFC (see Figure A.II.3)}

Preheated air is added to the gasifier to partially oxidize the pyrolysis oil. The system will be the simplest to operate, since no recycles are included and heat is produced inside the gasifier. However, the electric efficiency will be lower compared to the other systems since part of the fuel is burned in the oxidizer.

\section{A.II.3 Model description}

The process models were built using Aspen Plus 11.1® software where the process conditions, gasifier and fuel cell type were varied. For modelling pyrolysis oil, ethylglycol diacetate $\left(\mathrm{C}_{6} \mathrm{H}_{10} \mathrm{O}_{4}\right)$ was chosen to give a CHO-elemental composition similar to dry pyrolysis oils $(\mathrm{C}=49.3, \mathrm{H}=7.0$ and $\mathrm{O}=43.8 \mathrm{wt} \%)$. Additionally, the enthalpy of formation was redefined corresponding to a dry LHV of $22 \mathrm{MJ} / \mathrm{kg}$ for the pyrolysis oil [5].

All gas compositions of the reactor effluents (gasifier, fuel cell and oxidation) are calculated by minimizing the Gibbs Free energy at the prevailing operating conditions of the reactors, e.g. chemical equilibrium is assumed in the various components: $\mathrm{H}_{2} \mathrm{O}, \mathrm{CO}_{2}$, $\mathrm{H}_{2}, \mathrm{CO}, \mathrm{CH}_{4}, \mathrm{~N}_{2}$, and $\mathrm{O}_{2}$. Because catalysts are used in combination with high reactor temperatures, this assumption has been considered to be reasonable. 


\section{Appendix II}

Pinch technology was used for analyzing the energy flows in the systems for possible heat integration optimization [5]. This method has been widely applied in industry to identify energy saving options. Composite diagrams (heat versus temperature) are defined from the hot and cold streams, which are respectively the heat sources and the heat requirements of the system. The closest temperature distance between the composite hot and cold streams is called the pinch point $\left(\Delta \mathrm{T}_{\mathrm{min}}\right)$ of the system.

Here, the composite diagrams were used to analyse if a system could be operated autothermally or not at certain process conditions. Crossing of the cold and hot stream curves (no $\Delta \mathrm{T}_{\min }$ ) means that the system can never be operated autothermally while if $\Delta \mathrm{T}_{\min }>0{ }^{\circ} \mathrm{C}$ and preferably $\Delta \mathrm{T}_{\min }>>50{ }^{\circ} \mathrm{C}$ the system can be operated on a selfsustaining basis. However, caution should be taken into account, since pinch technology is based on an ideal heat integration network, while a practical network still has to be chosen. Additionally, heat losses to the environment will always give less integration possibilities than ideally calculated. 


\section{A.II.4 Results}

Table A.II.1 shows the standard values of the process conditions in the models.

Table A.II.1. Process conditions used in the models

\begin{tabular}{l|c}
\hline & Standard \\
\hline Gasifier temperature $\left({ }^{\circ} \mathrm{C}\right)$ & 700 \\
Gas clean-up temperature $\left({ }^{\circ} \mathrm{C}\right)$ & 450 \\
$\mathrm{MCFC}$ temperature inlet $\left({ }^{\circ} \mathrm{C}\right)$ & 600 \\
$\mathrm{MCFC}$ temperature outlet $\left({ }^{\circ} \mathrm{C}\right)$ & 700 \\
$\mathrm{SOFC}$ temperature inlet $\left({ }^{\circ} \mathrm{C}\right)$ & 900 \\
$\mathrm{SOFC}$ temperature outlet $\left({ }^{\circ} \mathrm{C}\right)$ & 1000 \\
Steam $\left(+\mathrm{CO}_{2}\right) /$ Carbon ratio & 4.5 \\
Water content pyrolysis oil $(\mathrm{wt} \%)$ & 25 \\
Conversion of fuel in the anode of the fuel cell $(\%)$ & 75 \\
Conversion of $\mathrm{O}_{2}\left(\mathrm{MCFC}+\mathrm{CO}_{2}\right)$ in the cathode of the fuel cell $(\%)$ & 50 \\
Electric efficiency of converted fuel $\left(\mathrm{H}_{2}\right.$ basis) in the fuel cell $(\%)$ & 60
\end{tabular}

Four process conditions were varied to evaluate how sensitive the alternative systems are. The varied process conditions and their values are given in Table A.II.2.

Table A.II.2. Process conditions varied for sensitivity analysis. For variation of the overall electric efficiency the conversion of fuel in the fuel cell anode is varied.

\begin{tabular}{l|c}
\hline & Sensitivity \\
\hline Reformer temperature $\left({ }^{\circ} \mathrm{C}\right)$ & $500-900$ \\
Steam $\left(+\mathrm{CO}_{2}\right) /$ Carbon ratio & $1.5-7.5$ \\
Water content pyrolysis oil (wt $\%)$ & $0-50$ \\
Overall electric efficiency $(\%)$ & $30-50$ \\
\hline
\end{tabular}

Figures A.II.1, A.II.2, and A.II.3 show the model process flow diagrams together with their pinch composite diagrams for steam reforming coupled with a MCFC (A), combined steam and dry reforming coupled with a SOFC (B) and partial oxidation coupled with a MCFC (C), respectively. The standard values of Table A.II.1 were used to construct the pinch composite diagrams. 

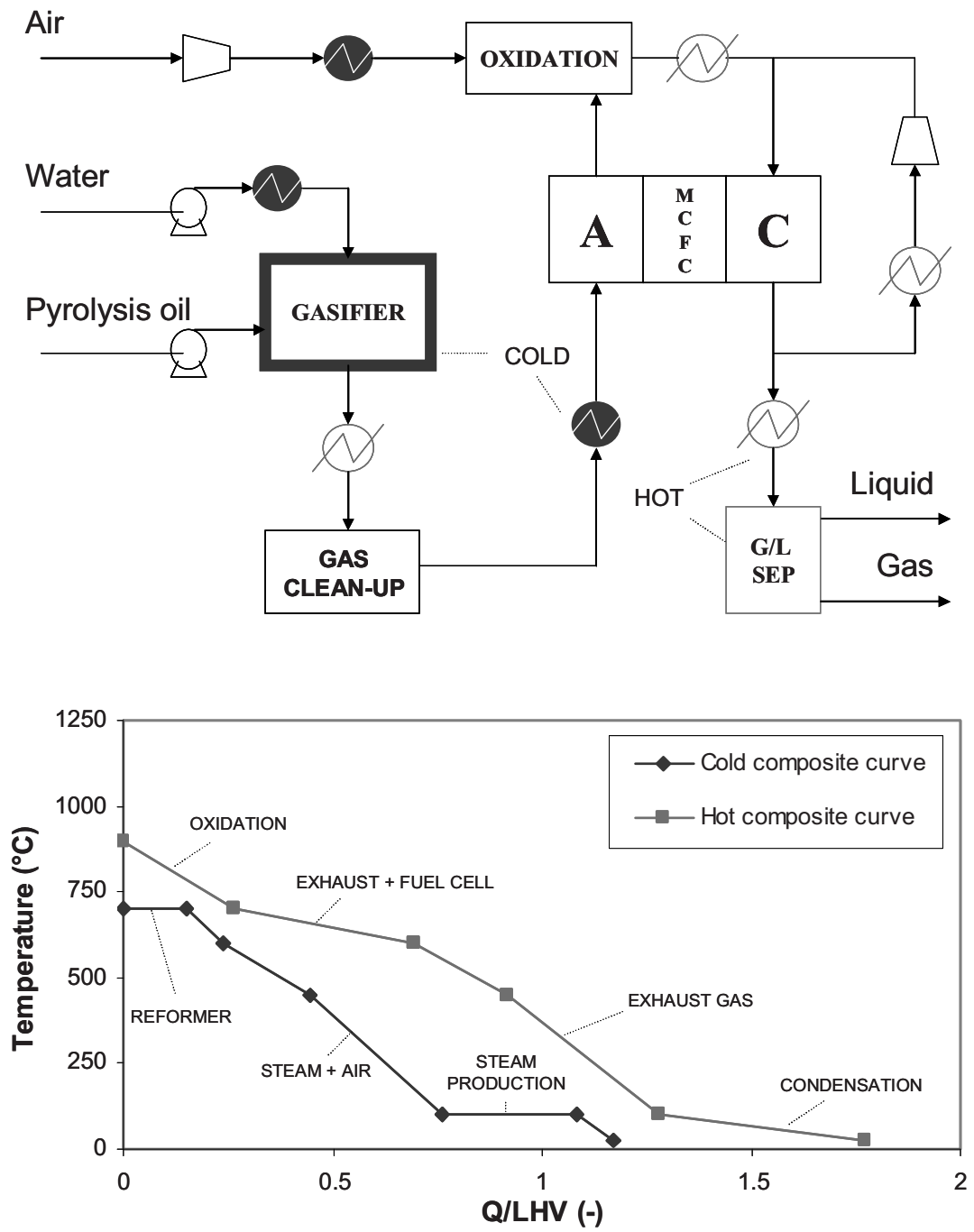

Figure A.II.1. (System A) Steam reforming followed by an MCFC. The X-axis displays the normalized heat $(\mathrm{Q})$ source/requirement. 

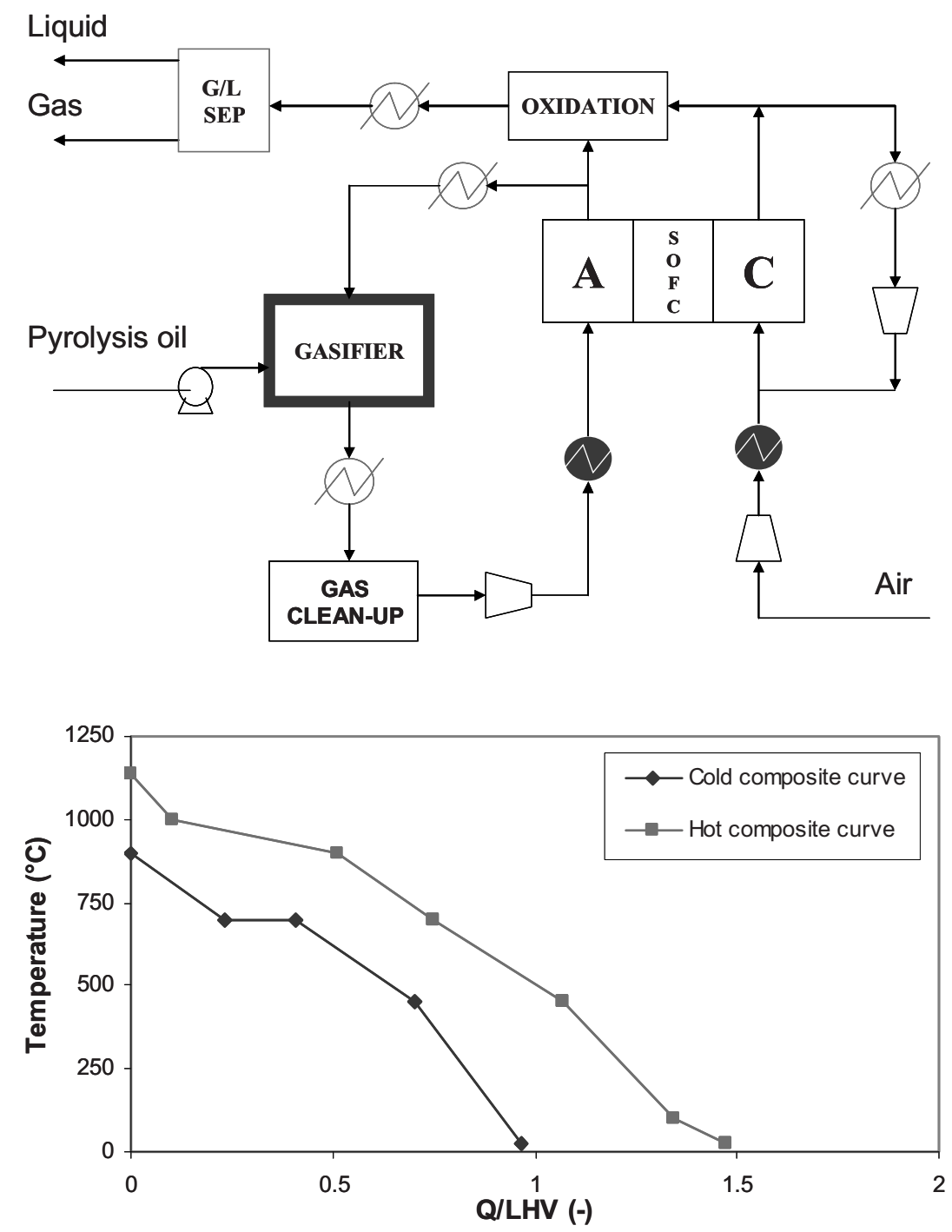

Figure A.II.2. (System B) Combined steam and dry reforming followed by a SOFC (anode recycling) 

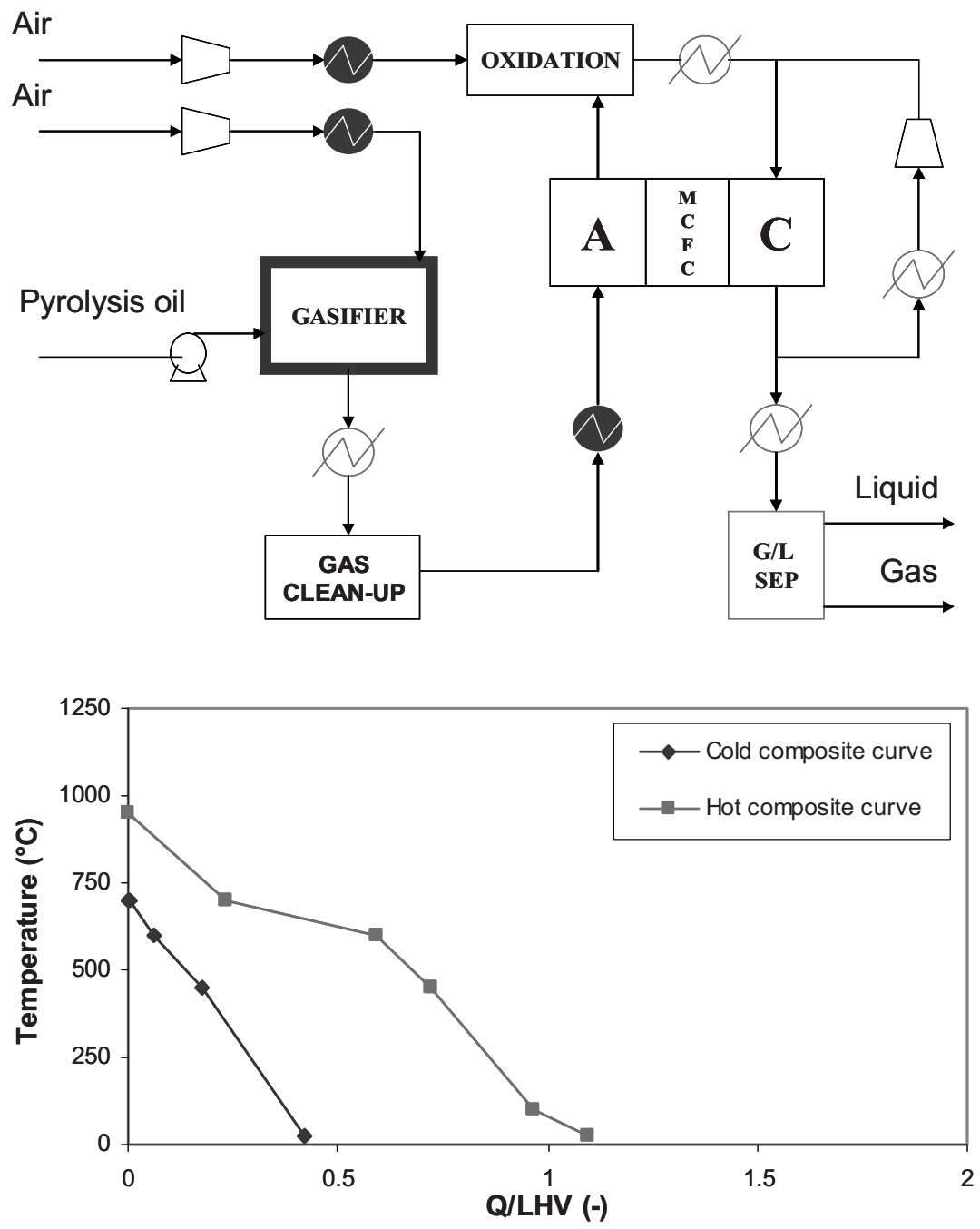

Figure A.II.3. (System C) Partial oxidation followed by a MCFC. 
Table A.II.3 shows a summary of results for the three Systems discussed in this paper.

Table A.II.3. Summary of results.

\begin{tabular}{l|ccc}
\hline & System & System & System \\
& A & B & C \\
\hline Electric efficiency $(\mathrm{LHV} \%$ to electricity) & 46.8 & 56.5 & 39.6 \\
Fuel cell anode outlet $\left(\mathrm{H}_{2}+\mathrm{CO}+\mathrm{CH}_{4}\right.$ vol\%) & 6.8 & 9.6 & 10.7 \\
Reformer outlet $\left(\mathrm{H}_{2}\right.$ of maximum \%) & 88 & 63 & 54 \\
Fuel cell cathode outlet $\left(\mathrm{CO}_{2}\right.$ vol\%) & 6.4 & & 9.3 \\
Heat to system $(\mathrm{Q} / \mathrm{LHV})$ & 1.17 & 0.97 & 0.42 \\
Heat from system $(\mathrm{Q} / \mathrm{LHV})$ & 1.77 & 1.47 & 1.10 \\
$\Delta \mathrm{T}_{\text {min }}\left({ }^{\circ} \mathrm{C}\right)$ & 88 & 190 & 241 \\
\hline Sensitivity analysis & & & \\
- Efficiency $(50 \%)$ & 0 & + & - \\
- T reformer $\left(900{ }^{\circ} \mathrm{C}\right)$ & - & + & - \\
$-(\mathrm{S}+\mathrm{C}) / \mathrm{C}$ ratio $(7.5)$ & - & + & n.a. \\
- Water in oil $(50 \mathrm{wt} \%)$ & - & + & + \\
\hline
\end{tabular}

(-) crossing of the composite curves,(0) $\Delta T_{\min }=0-50^{\circ} \mathrm{C}$

(+) $\Delta T_{\min }>50^{\circ} \mathrm{C}$ and (n.a.) not applicable

The following can be highlighted from the results:

- The gasifier gives a temperature plateau at $700{ }^{\circ} \mathrm{C}$ in (A) and (B) due to the endothermic reforming reactions and the indirect evaporation and heating of the cold pyrolysis oil in the gasifier. In (C) the exothermic partial oxidation reaction compensates for the energy required for indirect heating of the pyrolysis oil.

- The electric efficiency is highest for (B), where part of the unconverted $\mathrm{H}_{2}$ and $\mathrm{CO}$ is recycled back to the gasifier creating an overall higher conversion of fuel per pass. (C) shows the lowest electric efficiency, since part of the fuel is used in the gasifier for the partial oxidation.

- When steam reforming is used in the gasifier (A), a large energy plateau is created due to the evaporation of water. This is avoided when anode off-gas is recycled from the fuel cell to the gasifier (B) or using air as a reactant (C).

- When a MCFC is used (A), the excess heat of the fuel cell is released at a 
Appendix II

temperature of $700{ }^{\circ} \mathrm{C}$. This heat is lower or in the same temperature range as the heat, which is needed for the gasifier and can therefore not be used as a source of heat for the gasifier. This makes the gasifier's heat duty totally dependent on the heat, which is released during oxidation of residual fuel. In practice, this heat exchange will be very difficult to accomplish from a technical and process control point of view. When a SOFC is used (B) the sensible heat from the fuel cell off-gas can easily be used for the reformer since it is at an attractive temperature of $1000{ }^{\circ} \mathrm{C}$. When no heat is needed for the gasifier (C), a MCFC could be a good option, since the heat is still released at an attractive temperature and less heat losses would be expected compared to the SOFC.

- When the total amount of heat transfer is compared, (A) needs the highest heat transfer, followed by (B) and (C). (A) mainly has a high heat transfer due to the steam production, while (B) has a high heat transfer due to operating at overall higher temperatures. A high needed heat transfer can be used as an indication for the complexity of the heat transfer network and for the amount of heat losses expected.

- Only (B) shows a very good response to the sensitivity analysis done, which can mainly be ascribed to the high temperature difference between the fuel cell and the rest of the system, and not having to generate steam. (C) shows a moderate response to the sensitivity analysis while (A) shows a bad response to the sensitivity analysis (see Table A.II.3). 


\section{A.II.4 Conclusions}

An application for catalytic pyrolysis oil gasification is the combination with decentralized stationary electricity production using high temperature fuel cells. The overall electric efficiency is high and heat is available at elevated temperatures, which can effectively be used when proper integration is applied. Three system configurations were presented in this Appendix, which in principal can be used for the conversion of pyrolysis oil to fuel cell electricity.

The systems differed in the gasifier type (steam reforming, combined steam and dry reforming and partial oxidation) and in type of fuel cell (MCFC and SOFC). Recycling of SOFC anode off-gas to the gasifier is, from an energetic point of view, the best option to convert pyrolysis oil to fuel cell electricity. The overall electric efficiency is the highest and heat integration is easily possible. Steam reforming coupled with a MCFC has strong restrictions on its operating window. Large amounts of energy are needed for the steam production and the excess heat of the fuel cell cannot be used for the gasifier. Partial oxidation coupled with a MCFC has as a main advantage that no additional heat is needed for the gasifier. However, a low overall electric efficiency is attained compared to the other two system configurations. 


\section{Appendix II}

\section{References}

1. Wang, X.; Kersten, S.R.A.; Prins, W.; Van Swaaij, W.P.M. Biomass-syngas from fast pyrolysis vapors or liquids. Proceedings of the $12^{\text {th }}$ European Conference on Biomass for Energy, Industry and Climate Protection, Amsterdam, The Netherlands, 2002, 781.

2. EG\&G Technical Services, Inc., Fuel Cell Handbook, $6^{\text {th }}$ edition, November 2002, DOE/NETL-2002/1179.

3. Czernik, S.; Bridgwater, A.V. Overview of Applications of Biomass Fast Pyrolysis Oil Energy \& Fuels 2004, 18, 590 .

4. ECN Biomass: Phyllis. www.ecn.nl/phyllis/, (accessed May 2004)

5. Godat, J.; Marechal, F. Optimization of a fuel cell system using process integration techniques. Journal of Power Sources 2003, 118, 411. 


\section{Dankwoord}

U hebt mijn Proefschrift in handen waar ik de afgelopen jaren met veel plezier en passie aan heb gewerkt. In deze periode heb ik veel steun en hulp gehad van anderen die ik graag wil bedanken.

Allereerst mijn promotor Wim van Swaaij en co-promotor Sascha Kersten. Ik ben erg blij dat ik onder jullie begeleiding op de Universiteit Twente mijn promotieonderzoek heb kunnen uitvoeren. Jullie hebben mij altijd op wetenschappelijk gebied geprikkeld en uitgedaagd. Ik ben ook dankbaar voor het vertrouwen dat jullie mij al in een vroeg stadium hebben gegeven om mijn wetenschappelijke carrière te ontwikkelen naast mijn promotieonderzoek. Ik kreeg van jullie de kans om mee te bouwen aan de groei van de TCCB groep. Daarnaast wil ik alle (oud) TCCB collega's bedanken voor de leuke en inspirerende samenwerking gedurende de afgelopen jaren, in het bijzonder: Benno, Biljana, Dragan, Erna, Karst, Kees, Mariken, Michiel, Rik, Robert, Roel, Wim, Wolter, Xiaoquan en Yvonne.

I am also very grateful to everybody who contributed to this work. First of all my students/colleagues of the TCCB group: Agnes, Antal, Ferran, Judith, Pavlina, Prasad, Rebeca, Tomàs. Secondly Berta, as my ACTS/CPM partner in research. Thirdly, the organizations that funded this research: NWO/ACTS, EU and SenterNovem. Additionally, I want to thank the following companies for the fine collaboration: BTG, Johnson Matthey, Clean Fuels/Carbo and Purac.

During my research I also made good friendships which I really appreciate a lot both during work and outside working hours: Agnes, Berta, Benno, Ferran, Judith, Mariken, Pavlina, Roel en Sascha. Next to that, over the years I have enjoyed my friendship with the 'Macandra' group, study friends, Spanish friends and Praedinius friends.

Als laatste wil ik mijn familie/familia, in het bijzonder mijn vader en mijn vrouw, bedanken voor de steun en liefde die ze mij hebben gegeven in de afgelopen jaren.

Guus van Rossum, Augustus 2009 


\section{Curriculum Vitae}

Guus van Rossum was born on February the $8^{\text {th }} 1979$ in Leiden, The Netherlands. After growing up in Leyden and in Canada (one year) he attended secondary school in Groningen (Praedinius Gymnasium).

He studied Chemical Engineering at the University of Groningen (RUG). During his study at the RUG (1997-2003) he was a member of several student boards of 'De Chemische Binding' and 'G.T.D. Bernoulli'. He also participated in setting up a new course for second year students and in teaching in this course. He completed an internship at Shell (Prof. ir. G.J. Harmsen) and graduated Cum Laude in May 2003 under the supervision of Prof. dr. ir. H.J. Heeres on the topic 'Ethylene oligomerization to $\alpha$-olefins using a homogeneous catalyst'.

In April 2003 he started his Ph.D. research in the group Thermo-Chemical Conversion of Biomass (TCCB) under the supervision of Prof. dr. ir. W.P.M. van Swaaij and Dr. S.R.A. Kersten on the topic 'Steam reforming and gasification of pyrolysis oil'. From January 2006 he was appointed as scientific staff member while continuing his Ph.D. research part time. From January 2009 he is a full time scientific staff member of the TCCB group. In May 2009 he was awarded with the Leo Petrus Innovation Trophy. 


\section{Publications}

Van Rossum, G.; Kersten, S.R.A.; Prins, W.; Van Swaaij, W.P.M. System configurations for the conversion of bio-oil to fuel cell electricity. $2^{\text {nd }}$ World Conference for Energy, Industry and Climate Protection, 10-14 May 2004, Rome, 1179.

Van Rossum, G.; Kersten, S.R.A.; Van Swaaij, W.P.M. Catalytic gasification of Bio-oil. Proceedings of the $14^{\text {th }}$ European Biomass Conference and Exhibition, 17-21 October 2005, Paris, 592.

Van Rossum, G.; Kersten, S.R.A.; Van Swaaij, W.P.M. Catalytic and Noncatalytic Gasification of Pyrolysis Oil. Ind. Eng. Chem. Res. 2007, 46, 3959.

Van Rossum, G.; Kersten, S.R.A.; Van Swaaij, W.P.M. Catalytic gasification of pyrolysis oil in a staged two bed reactor. Proceedings of the $15^{\text {th }}$ European Biomass Conference and Exhibition, 7-11 May 2007, Berlin, 1153.

Van Rossum, G.; Kersten, S.R.A.; Van Swaaij, W.P.M. Staged Catalytic Gasification of Pyrolysis Oil to Synthesis Gas. Proceedings of the $16^{\text {th }}$ European Biomass Conference and Exhibition, 2-6 June 2008, Valencia, 1001.

Van Rossum, G.; Potic, B.; Kersten, S.R.A.; Van Swaaij, W.P.M. Catalytic Gasification of Dry and Wet Biomass. Catalysis Today 2009, 145, 10.

Van Rossum, G.; Kersten, S.R.A.; Van Swaaij, W.P.M. Staged Catalytic Gasification/Steam Reforming of Pyrolysis Oil. Ind. Eng. Chem. Res. 2009, 48, 5857. 


\section{Publications}

Balegedde Ramachandran, R.P.; Van Rossum, G.; Van Swaaij, W.P.M.; Kersten, S.R.A. Evaporation of biomass fast pyrolysis oil: Evaluation of char formation. Environmental Progress 2009, accepted.

Van Rossum, G.; Matas Güell, B.; Balegedde Ramachandran, R.P.; Seshan, K.; Lefferts, L.; Van Swaaij, W.P.M.; Kersten, S.R.A. Evaporation of pyrolysis oil: product distribution and residue char analysis. AIChE journal 2009, submitted.

Matas Güell, B.; Van Rossum, G.; Van Swaaij, W.P.M.; Kersten, S.R.A.; Lefferts, L.; Seshan, K. Challenges in the production of sustainable fuels from pyrolysis oil - Design of efficient catalysts for gasification of char. Fuel 2009, submitted. 